\title{
Enter the Matrix: An Examination of Patrick Pound's The Great Exhibition
}

\section{Milly Mitchell-Anyon}

A thesis submitted to the Victoria University of Wellington in fulfilment of the requirements for the degree of Master of Arts in Art History 


\section{Contents}

Abstract ii

Acknowledgements iii

List of Illustrations iv

Introduction: Patrick Pound and The Great Exhibition 1

Chapter One: Authorship/Meaning $\quad 19$

Defining the Author $\quad 20$

Curriculum Vitae - A Case Study of Deceit 26

Postmodern Ideologies of Authorship $\quad 32$

A Selected History of Pound's 'Found' Works

$\begin{array}{ll}\text { Photography and its Authors } & 39\end{array}$

Burn's Art History $\quad 45$

The Instability of Meanings $\quad 51$

Categorising and Constraining the World 55

Chapter Two: Vernacular Photography

Defining the Vernacular $\quad 62$

The Function of Snapshots $\quad 69$

Photographic Memory $\quad 70$

'An Endless Torrent' $\quad 76$

Our Archival Condition $\quad 84$

$\begin{array}{ll}\text { Chapter Three: Algorithms } & 91\end{array}$

'Artist-as-curator' $\quad 92$

$\begin{array}{lr}\text { C'est eBay } & 101\end{array}$

$\begin{array}{ll}\text { Georges Perec and the OuLiPo } & 106\end{array}$

$\begin{array}{ll}\text { Thoughts-of-sorts } & 109\end{array}$

$\begin{array}{ll}\text { Robert Rauschenberg and Formulaic Intersections } & 113\end{array}$

Conclusion: On Reflection 116

Illustrations $\quad 122$

$\begin{array}{lr}\text { Bibliography } & 190\end{array}$ 


\begin{abstract}
This thesis considers the practice of New Zealand-born artist, Patrick Pound (b. 1962) through an analysis of his survey show, Patrick Pound: The Great Exhibition, which was staged at the National Gallery of Victoria in Melbourne between 31 March and 30 July 2017. The Great Exhibition demonstrates the complexity and multiplicity of Pound's practice, exemplifying the interconnectedness of his thinking and his use of an algorithmic approach to collecting, curating and categorisation. His depth of art-historical knowledge plays out as an intricate puzzle that I unpick within this thesis.
\end{abstract}

The scope of The Great Exhibition is vast and, while it might appear to mostly involve the arrangement of more than 4,000 vernacular photographs and found objects, alongside 300 items from the NGV's collection, the methodologies of collecting and curation employed by Pound are multifaceted.

In Chapter One I consider the constancy of Pound's interrogation of authorship and meaning throughout his practice, which is integrally related to his use of vernacular photographs and found objects within The Great Exhibition. In Chapter Two, I examine our relationship with vernacular photography and how this is exposed in The Great Exhibition. The practices of artists such as Erik Kessels, Joachim Schmid and Marcel Duchamp provide context here.

Chapter Three asks how The Great Exhibition fits within a wider context of exhibitions by artist-as-curators such as Fred Wilson's Mining the Museum and Edward Steichen's The Family of Man. This chapter also examines how computer algorithms can be applied as a framework for understanding The Great Exhibition's curatorial logic. Pound's complex system of sorting and categorising into matrices and intersections is considered in relation to writer Georges Perec and his understanding of Alan Turing's conceptualisation of the 'Automatic' and 'Oracle' machines. My conclusion reflects on what can and cannot be learned from Patrick Pound's The Great Exhibition. 


\section{Acknowledgements}

\section{Ehara taku toa i te toa takitahi, engari he toa takitini}

Success is not the work of one, but the work of many

From the bottom of my heart, thank you to Roger Blackley (1953-2019) for fuelling this thesis with almond croissants, cups of teas, glasses of your favourite red wine ("grown on the slopes of Mount Vesuvius"), with your encyclopaedic knowledge, incredible wit, kindness and love. You gifted me, and countless others, a love of art history.

Thank you to my supervisor, Geoffrey Batchen, who helped me immensely, providing thoughtful avenues to explore and trusting in my process. If it were not for The Great Exhibition catalogue you lent me, I would never have embarked on this topic.

I am forever grateful to Patrick Pound, for all the bad (good) puns and Dad jokes I have processed for the last year. Perhaps I should have called this thesis 365 days of Patrick Pound (laughs).

Thanks to Maggie Finch, National Gallery of Victoria, Victoria Boyack, Te Aka Matua Library at Te Papa Tongarewa, Adam Art Gallery and Ngā Taonga Sound \& Vision.

I could not have done this without the rest of the Art History department; Pippa Wisheart, David Maskill, Ray Spiteri, Tina Barton and Peter Brunt. You have all helped me succeed with your considered discussion and encouragement.

Thanks for all the aroha Anna-Marie White, Kirsty Baker and Lachlan Taylor. It has been a true privilege to have shared an office with you and learn so much along the way.

Lots of love to my family, but especially Mum - thank you for all the support you have provided. I truly could not have done this without you. 


\section{List of Illustrations}

Fig. 1 Detail of Patrick Pound, The Tailor's Library. (Melbourne, VIC, Michael Wardell Gallery, 1996). Accessed at Te Aka Matua Research Library, Te Papa Tongarewa.

Fig. 2 Discogs, Lester Gaba, N.d. Retrieved from https://www.discogs.com/artist/2756088-Lester-Gaba. Accessed 12 May 2018.

Fig. 3 Rowan McNaught and Patrick Pound, The compound lens project, 2014-2015, computer programme. Detail retrieved from http://compound-lens.com/. Accessed 12 May 2018.

Fig. 4 Rowan McNaught and Patrick Pound, The compound lens project, 2014-2015, computer programme. Detail retrieved from http://compound-lens.com/. Accessed 12 May 2018.

Fig. 5 Exhibition title at Patrick Pound: The Great Exhibition, May 2017, photograph by author.

Fig. 6 Detail of Patrick Pound's falsified identity in Peter Hill, 'An Encyclopaedia of Patrick Pound's Superfictions,' Photofile 91 (December 2010): 61).

Fig. 7 Detail of Patrick Pound, The Tailor's Library. (Melbourne, VIC, Michael Wardell Gallery, 1996). Accessed at Te Aka Matua Research Library, Te Papa Tongarewa.

Fig. 8 Sherrie Levine, After Walker Evans: 4, 1981, gelatin silver print, (Metropolitan Museum of Art: New York, NY).

Fig. 9 Walker Evans, Alabama Tenant Farmer Wife, 1936, gelatin silver print, (Metropolitan Museum of Art: New York, NY).

Fig. 10 Detail of Drive by (en passant) at Patrick Pound: The Great Exhibition, May 2017, photograph by author.

Fig. 11 Detail of The Cliff House at Patrick Pound: The Great Exhibition, May 2017, photograph by author. 
Fig. 12 Patrick Pound, No, 2005, oil paint and books, (Hamish McKay: Wellington, NZ).

Fig. 13 Patrick Pound, Flinders Notebook, 2007, oil paint on board, (Hamish McKay: Wellington, NZ).

Fig. 14 Robert Rauschenberg, Erased de Kooning Drawing, 1953, paper and gilded frame, (SFMoMA: San Francisco, CA).

Fig. 15 Kazimir Malevich, Black Square, 1915, oil paint on linen, (Tretyakov Gallery, Moscow).

Fig. 16 Ian Burn, 'Value Added' Landscape no. 11, 1993, oil paint on board with perspex, (AGNSW: Sydney, Australia).

Fig. 17 John Brack, The car, 1955, oil paint on canvas, (NGV: Melbourne, Australia).

Fig. 18 Detail of John Brack's The car with Drive by (en passant) at Patrick Pound: The Great Exhibition, May 2017, photograph by author.

Fig. 19 Still from Orson Welles, François Reichenbach, Gary Graver, and Oja Kodar (dirs.). F for Fake (Germany, Planfilm, 1973), Blu-Ray.

Fig. 20 Detail of John Brack's four (Study for The car) with Drive by (en passant) at Patrick Pound: The Great Exhibition, May 2017, photograph by author.

Fig. 21 Detail of The Museum of There / Not there at Patrick Pound: The Great Exhibition, May 2017, photograph by author.

Fig. 22 Detail of The Museum of There / Not there at Patrick Pound: The Great Exhibition, May 2017, photograph by author.

Fig. 23 David Moore, Migrants arriving in Sydney, 1966, gelatin silver print, (NGV: Melbourne, Australia).

Fig. 24 Alfred Stieglitz, The steerage, 1907 [printed 1911], photogravure, (NGV: Melbourne, Australia). 
Fig. 25 Detail of Rowan McNaught and Patrick Pound's Thoughts-of-sorts at Patrick Pound: The Great Exhibition, May 2017, photograph by author.

Fig. 26 Detail of 'wheel' in The Museum of holes at Patrick Pound: The Great Exhibition, May 2017, photograph by author.

Fig. 27 Detail of The photographer's shadow at Patrick Pound: The Great Exhibition, 2017, photograph by Wayne Taylor. Retrieved from https://artblart.com/2017/07/26/review-patrick-pound-the-greatexhibition-at-ngv-australia-melbourne-part-2/. Accessed 30 July 2018.

Fig. 28 Detail from The photographer's shadow at Patrick Pound: The Great Exhibition, May 2017, photograph by author.

Fig. 29 Detail from The hand of the photographer at Patrick Pound: The Great Exhibition. Retrieved from https://www.ngv.vic.gov.au/exhibition/patrick-pound/. Accessed 30 July 2018.

Fig. 30 Detail of The entrants from foyer of NGV at entrance of Patrick Pound: The Great Exhibition, May 2017, photograph by author.

Fig. 31 Installation shot of The sleeping gallery at Patrick Pound: The Great Exhibition, 2017, photograph by Wayne Taylor. Retrieved from https://artblart.com/2017/07/26/review-patrick-pound-the-greatexhibition-at-ngv-australia-melbourne-part-2/. Accessed 30 July 2018.

Fig. 32 Detail from Damaged at Patrick Pound: The Great Exhibition. Retrieved from https://www.ngv.vic.gov.au/exhibition/patrick-pound/. Accessed 30 July 2018.

Fig. 33 Erik Kessels, 24 Hours in Photos, 2011, multimedia, installation staged December 2011 - January 2012 at FOAM: Amsterdam, Holland. Retrieved from http://www.kesselskramer.com/exhibitions/24-hrs-of-photos. Accessed 30 July 2018.

Fig. 34 Detail of Charlie Sheen in Drive by (en passant) at Patrick Pound: The Great Exhibition, May 2017, photograph by author. 
Fig. 35 Detail from Damaged at Patrick Pound: The Great Exhibition, May 2017, photograph by author.

Fig. 36 Erik Kessels, IN ALMOST EVERY PICTURE \#13, 2014, book. Detail retrieved from http://kesselskramerpublishing.com/catalogue/inalmost-every-picture-13/. Accessed 30 July 2018.

Fig. 37 Detail from The hand of the photographer at Patrick Pound: The Great Exhibition, May 2017, photograph by author.

Fig. 38 Patrick Pound, Documentary Intersect, multimedia, installation staged 30 July 2016 - 18 September 2016 at Adam Art Gallery: Wellington, New Zealand. Retrieved from http://www.adamartgallery.org.nz/pastexhibitions/opening-friday-29-july-6pm/. Accessed 30 July 2018.

Fig. 39 Joachim Schmid, Archiv \#001, 1986, postcards mounted and framed, (collection unknown).

Fig. $40 \quad$ Marcel Duchamp, The bride stripped bare by her bachelors, even (The green box), 1934, box of collotypes, (Metropolitan Museum of Art, New York, NY).

Fig. $41 \quad$ Marcel Duchamp, The bride stripped bare by her bachelors, even (The Large Glass), 1915-1923, oil, varnish, lead foil and wire, dust, glass plates, (Philadelphia Museum of Art: Philadelphia, PA).

Fig. 42 Marcel Duchamp, Boîte-en-valise, 1935-1941, leather valise, photographs, colour reproductions, collotype on celluloid, (Museum of Modern Art, New York, NY).

Fig. 43 Detail from The game of things at Patrick Pound: The Great Exhibition, May 2017, photograph by author.

Fig. 44 Detail from The game of things at Patrick Pound: The Great Exhibition, May 2017, photograph by author.

Fig. 45 Detail from Fred Wilson's Mining the Museum, installation staged 3 April 1992 - 28 February 1993 at Maryland Historical Society. Retrieved from http://www.mdhs.org/digitalimage/installation-viewpedestals-globe-and-busts. Accessed 31 July 2018. 
Fig. 46 Installation shot from The Museum of There / Not there at Patrick Pound: The Great Exhibition, May 2017, photograph by author.

Fig. 47 Installation shot from The Museum of There / Not there at Patrick Pound: The Great Exhibition, May 2017, photograph by author.

Fig. 48 François Peron, Louis de Freycinet and Arthus Bertrand published, Music of the Natives of New South Wales (Musiques des sauvages de la Nouvelle-Galles du Sud), 1824, engraving, (NGV: Melbourne, Australia).

Fig. 49 Unknown, Bennelong, 1802 engraving and etching, (NGV:

Melbourne, Australia).

Fig. $50 \quad$ Installation shot from The Museum of There / Not there at Patrick Pound: The Great Exhibition, May 2017, photograph by author.

Fig. 51 Detail from The names in The collection shelves in Patrick Pound: The Great Exhibition, May 2017, photograph by author.

Fig. 52 Installation shot from Edward Steichen's The Family of Man, exhibition staged 24 January 1955 - 8 May 1955 at Museum of Modern Art. Retrieved from https://www.moma.org/calendar/exhibitions/2429. Accessed 31 July 2018.

Fig. 53 Installation shot from The Museum of Falling in Patrick Pound: The Great Exhibition, May 2017, photograph by author.

Fig. 54 Photograph of author in reflection beside The photographer's shadow in Patrick Pound: The Great Exhibition, May 2017, photograph by author.

Fig. 55 Detail from The Cliff House and intersections in Patrick Pound: The Great Exhibition, May 2017, photograph by author.

Fig. 56 Detail from The Cliff House in Maggie Finch, The Great Exhibition, ed. Mark Gomes (Melbourne, VIC: National Gallery of Victoria, 2017), 149. 
Fig. 57 First postcard of From Cliff House that arrived in an envelope with Heinz Sielmann stamps. Photograph by author.

Fig. 58 First [top] and second postcard of From Cliff House. Photograph by author.

Fig. 59 Four postcards From Cliff House. Photograph by author.

Fig. 60 Installation shot from The collection shelves in Patrick Pound: The Great Exhibition, May 2017, photograph by author.

Fig. 61 Detail from 26 brown things from Patrick Pound: The Great Exhibition, May 2017, photograph by author.

Fig. 62 Detail from The Collector from Patrick Pound: The Great Exhibition, May 2017, photograph by author

Fig. 63 Félix Vallotton, Point du Jour, banks of the Seine (Point du Jour, bords de la Seine), 1901, oil paint on canvas, (NGV: Melbourne, Australia).

Fig. 64 Detail from Drive by (en passant) intersecting with The Museum of holes in Patrick Pound: The Great Exhibition, May 2017, photograph by author.

Fig. 65 Detail from The Museum of holes in Patrick Pound: The Great Exhibition, May 2017, photograph by author.

Fig. 66 Installation shot showing intersections with The Museum of falling in Patrick Pound: The Great Exhibition, May 2017, photograph by author.

Fig. 67 Robert Rauschenberg, Stoned Moon Drawing, 1969, collage and crayon on illustration board, (Robert Rauschenberg Foundation).

Fig. 68 Detail from The readers in Patrick Pound: The Great Exhibition, May 2017, photograph by author.

Fig. 69 Erik Kessels, IN ALMOST EVERY PICTURE \#4, 2005, book. Detail retrieved from http://kesselskramerpublishing.com/catalogue/inalmost-every-picture-4/. Accessed 30 July 2018. 


\title{
Introduction: Patrick Pound and The Great Exhibition
}

\author{
I want to put the dad joke in conceptual art. ${ }^{1}$ \\ Patrick Pound
}

When I first came across a catalogue from Patrick Pound's 1996 exhibition, titled The Tailor's Library and held in his artist file at Te Papa's research library, I was struck by a reproduction of a photograph on the second-to-last page [Fig. 1]. ${ }^{2} \mathrm{~A}$ man with dark hair, combed back and parted to the side, was leaning forward. His facial features were accentuated by the shadows, transformed by the hard studio lights. Staged and familiar, the image connotes a pose reserved for the author's biography on the end-sheet in a book. Underneath the Xeroxed tones, the caption for the image reads: 'Patrick Pound is an artist based in Melbourne, Australia.'

The same image appeared in the article titled 'An Encyclopaedia of Patrick Pound's Superfictions' in 2010. In this article, Curator Peter Hill compiles a chronology detailing Pound's practice, based on his ongoing work C.V.-a work in progress (c. 1990s) and his 'fictions.' A double-page spread reveals that the image of the young man identified as Pound is, in fact, Lester Gaba (1907-1987), a soap sculptor and window dresser from New York [Fig. 2]. ${ }^{3}$ In her writing on photography and captions, Susan Sontag argued that a caption is 'expected to speak for the truth,' by superseding 'the evidence of our eyes. ${ }^{4}$ In the aforementioned case, the caption provides the evidence to verify that the image of Gaba is 'Patrick Pound,' the 'artist based in Melbourne, Australia.'

\footnotetext{
${ }^{1}$ Patrick Pound, The Space Museum Guide / Collected Works: Telling Things. (Melbourne, VIC: Fehily Contemporary, 2011), 10, http://melanierogergallery.com/media/media/files/2012_11/Patrick_Pound_The_Space_Mus eum_Guide_20110001.pdf.

${ }^{2}$ Patrick Pound, The Tailor's Library. (Melbourne, VIC, Michael Wardell Gallery, 1996), 7.

${ }^{3}$ Peter Hill, "An Encyclopaedia of Patrick Pound's Superfictions," Photofile 91 (December 2010): 61.

${ }^{4}$ Susan Sontag, On Photography (London, UK: Penguin Classics, 2002), 108-9.
} 
Incidents of deception appeared regularly while I was researching Patrick Pound. The young man I was gazing at was not Pound but, instead, a substitute for the artist; a fiction, a 'delusion to be exposed.'5 Pound's practice can be characterised as one that consistently 'tampers with truth' and the photograph that Pound presents as himself is evidence of this. ${ }^{6}$ It is part of his own 'systematic parody' of the art world. ${ }^{7}$ The incorrect caption is just one isolated example of Pound's ongoing parodies, but it epitomises a wider framework in which his practice operates. As a result, I have come to accept that primary pieces of evidence are, in fact, further chapters in this parody. So, when the artist declares 'I want to put the dad joke into conceptual art,' the adage must be taken seriously. ${ }^{8}$ This thesis will, then, provide neither a chronological nor a monolithic study of Pound. It will instead be a critical analysis of Patrick Pound: The Great Exhibition as an exhibition, as an artwork and as a culmination of ideas that Pound has been pursuing since 1985. Nevertheless, an exploration of Pound's practice prior to the staging of The Great Exhibition will be crucial in order to contextualise his work.

To provide some background, Patrick Pound: The Great Exhibition was presented during the Festival of Photography between 31 March and 30 July 2017 at the National Gallery of Victoria (NGV) in Melbourne, Australia. The Great Exhibition provides us with a robust example of Pound's practice - not only is it the largest show he has staged but the venue, the NGV, is a testament to the exhibition's importance within his artistic career. Encompassing seven galleries and the foyer of the NGV, the exhibition included around 4,000 vernacular photographs and objects from Pound's personal collection, and also incorporated

\footnotetext{
${ }^{5}$ Jonathan Culler, Barthes, ed. Frank Kermode (Glasgow, Scotland: Fontana Paperbacks, 1983), 33.

${ }^{6}$ Peter Hill, "Extracts from: The Encyclopaedia of Photofictions," Photofile 59 (April 2000): 20.

${ }^{7}$ Hill, "Extracts from: The Encyclopaedia of Photofictions," 20.

${ }^{8}$ Pound, The Space Museum Guide / Collected Works: Telling Things, 10.
} 
over 300 items from the NGV's collection. ${ }^{9}$ The abundant nature of the exhibition is noted by Pound, as he jokes about the title:

I did suggest they call the show Enough Already but they went with The Great Exhibition. Perhaps the best thing about that is that even people who really don't like it will still have to call it The Great Exhibition. ${ }^{10}$

The Great Exhibition is ambitious in scope, excessive in execution and, consequently, it is an arduous task, nearly impossible task, for the viewer to physically see every piece on display. This is perhaps best exemplified by my own witnessing of one person who turned the corner and said, 'Oh Fuck!' as they entered the first gallery space past the hallway. Pound deliberately challenges viewers to accept that they can never see The Great Exhibition in its entirety because of the overwhelming volume of the show. He emphasises these characteristics in the catalogue that accompanies the show when he quotes Georges Perec:

You can look at a piece of a puzzle for three whole days, you can believe that you know all there is to know about its colouring and shape, and be no further on than when you started. The only thing that counts is the ability to link this piece to the other pieces. ${ }^{11}$

In many ways, using this supposition as a guiding methodology to decipher The Great Exhibition appears to be the only plausible mechanism for moving forward. The impossibility of the task is exemplified in the pyramidal piles of photographs in vitrines, or the photographs affixed several metres up the gallery wall, inaccessible and impossible to view by spectators - or the internet-based piece that alters each time it runs. We are left to link the pieces of The Great Exhibition

\footnotetext{
${ }^{9}$ Will Cox, "Scouring EBay for Art with Patrick Pound," Broadsheet, April 24, 2017, https://www.broadsheet.com.au/melbourne/art-and-design/article/scouring-ebay-art-patrickpound-ngv.

${ }^{10}$ Maggie Finch, "Patrick Pound: The Great Exhibition Artwork Labels" (National Gallery of Victoria, 2017), 18, https://www.ngv.vic.gov.au/wpcontent/uploads/2016/09/PatrickPound_ArtworkLabels.pdf.

${ }^{11}$ Maggie Finch, "Introduction," in The Great Exhibition, ed. Mark Gomes (Melbourne, VIC: National Gallery of Victoria, 2017), 3.
} 
together and decode an impossible puzzle. Even if you were to see all the pieces of that puzzle, it remains a limitless matrix of possibilities. This has been a challenge in the writing of this thesis but simultaneously exemplifies how the very nature of Pound's practice is reflected in The Great Exhibition.

The title, The Great Exhibition, is a nod to the history of great exhibitions referencing the 'epic ambitions of Great Exhibition of the Works of Industry of All Nations' (1851). ${ }^{12}$ Just like the 1851 exhibition, Patrick Pound: The Great Exhibition convincingly attempts to categorise the world through 'things'. As the artist asserts: 'To collect is to gather your thoughts through things.' ${ }^{13}$ Examining how Pound creates these categories and collects 'things' will be key to understanding the foundations of his practice. This will lead to a structure that facilitates an analysis of how The Great Exhibition functions as an artwork.

For this thesis, I have elected not to interview Patrick Pound. The first factor in this decision was my desire to allow a critical distance between myself and the subject of my research. Furthermore, Pound demonstrates a consistent blurring of reality and fiction that makes him an unreliable interviewee. Rather, I rely primarily on my own interpretation and analysis of The Great Exhibition, undertaken while visiting the NGV in May 2017. Supplementing this, I have drawn on artworks, archival material, reviews and exhibition catalogues to augment my understanding of his practice and The Great Exhibition in particular.

The catalogue accompanying the exhibition, Patrick Pound: The Great Exhibition was published by the NGV. It consists of an 'Introduction,' followed by 'A Conversation: Patrick Pound and Maggie Finch,' both written by co-curator of the exhibition, Maggie Finch. This is supplemented with an essay by Geoffrey Batchen, 'Keepers: Patrick Pound and the Art of Collecting.' All three essays inform my research as the key body of critical scholarship and analysis in relation

\footnotetext{
${ }^{12}$ Finch, "The Great Exhibition Artwork Labels," 18.
}

${ }^{13}$ Finch, 17. 
to such a substantial exhibition staged by Pound. The Australian, Art Guide Australia, Sydney Morning Herald and Broadsheet all provided cursory reviews, while Neil Maizels' luke-warm review in Arena Magazine questioned the purpose of the exhibition and its 'uninspiring' aesthetics: 'And so, at its worst, The Great Exhibition is not particularly great, if judged only by our more usual artistic sensibility.' ${ }^{14}$ Ironically Maizels falls into Pound's titling trap here. Curator Robert Leonard wrote about The Great Exhibition on his online blog, perhaps ultimately leading to a New Zealand iteration, or response show, scheduled for City Gallery Wellington in August 2018. There was no critical response to The Great Exhibition from New Zealand reviewers, with the exception of Batchen's contribution to the exhibition catalogue.

While I argue that The Great Exhibition rejects the trope of the biographical narrative as a means to 'explain' the exhibition, it is important to provide a précis of Pound's life, so we are positioned to understand the artist's long-standing examination of biography, authorship and identity. In order to contextualise The Great Exhibition, I look at Pound's practice from 1985 onwards in order to position the exhibition within a wider conceptual framework developed throughout his career. A few facts would be a helpful start. Patrick Charles Pound was born on 25 March 1962 to parents Kevin and Hillary Pound, in Hamilton, New Zealand. He was one of eight siblings, alongside Francis, John, Mary, Brian, Thomas, Simon and Nicholas. The Pounds moved around New Zealand as Kevin Pound took up teaching posts in different regions. Patrick Pound began studying at Elam School of Fine Arts at Auckland University in 1984, graduating in 1987 with a Bachelor's degree with a double major in Fine Arts and Art History.

In 1989, Pound emigrated to Melbourne, Australia, where he has been based ever since. Pound is represented by both New Zealand and Australian dealer galleries, and still exhibits regularly in both countries. He remains situated within the consciousness of New Zealand, with some of Pound's works held in the

\footnotetext{
${ }^{14}$ Neil Maizel, "Patrick Pound: The Great Exhibition,” Arena Magazine, July 2017, 51.
} 
collections of major institutions such as Te Papa, Ngā Taonga Sound \& Vision, Waikato Museum of Art and History, Auckland Art Gallery, Dunedin Public Art Gallery, Govett-Brewster Art Gallery and the Christchurch Art Gallery. However, Pound's more recent works are also held in Australian collections like the NGV, Art Gallery of New South Wales (AGNSW), Art Gallery of South Australia (AGSA) and National Gallery of Australia (NGA). Pound became further entrenched within an Australian cultural milieu when he was included in The Photograph and Australia (4 July - 11 October 2015), an exploration of photography in Australia from 1840 to the present, curated by Judy Annear at the AGNSW. In the accompanying publication, Pound is cited as a 'New Zealandborn and Melbourne-based' artist. ${ }^{15}$ Pound's site-specific installation, The readers (2011-15), was set-up in the research library in the AGNSW, rather than the rarefied space of the gallery. The compound lens project (2014-2015) [Fig. 3 and Fig. 4], a collaboration between Melbourne-based artist Rowan McNaught and Patrick Pound, was also included in The Photograph and Australia. The work is a web-based programme that sorts digitised copies of Pound's vernacular photographic collection, based on the inherent similarities the programme can identify. ${ }^{16}$ No doubt a pun on Pound's name, the software 'compounds' the collection into his visual categories - just as Pound does. I will return to this, along with other collaborations between McNaught and Pound, in Chapter Three.

The Photograph and Australia contextualised Pound alongside some of Australia's more prominent artists, such as Max Dupain, David Moore, Tracey Moffatt and Ricky Maynard. Pound is implicated in the narrative of 'The Photograph' and 'Australia,' bringing another nationalist claim to the rhetoric around his work. After all, his first retrospective, Patrick Pound: The Great Exhibition, was held at the NGV, an Australian institution. To provide some

\footnotetext{
${ }^{15}$ Judy Annear et al., The Photograph and Australia / with Essays by Geoffrey Batchen, Daniel Palmer, Michael Aird, Jane Lydon, Katherine Davidson and Martyn Jolly. (Sydney, Australia: Art Gallery of New South Wales, 2015), 284.

${ }^{16}$ Georgina Cole, "The Compound Lens Project," Art Gallery NSW, April 13, 2015, https://www.artgallery.nsw.gov.au/blog/posts/compound-lens-project/.
} 
further background about the NGV, there are two physical sites for the Gallery the Ian Potter Centre: NGV Australia in Federation Square and the NGV International, both in Melbourne. The Ian Potter Centre was opened in 2003 as a space for the "home of Australian art, presenting Indigenous and non-Indigenous art. ${ }^{17}$ It is of note that The Great Exhibition was staged here, where it occupied the entire ground level of the gallery. Throughout this thesis, I will be referring to the Ian Potter Centre: NGV Australia as the NGV, thus representing the overarching institution in which The Great Exhibition was staged.

Pound's departure to Australia in 1989 could, in part, be explained as an effort to move away from the periphery and closer to the centre, although it might be contested that Australia is hardly the centre of the art world. When Terry Smith postulated in 'The Provincialism Problem' (1974) that New York was the 'center for the visual arts' and that those outside 'stand in a provincial relationship' to that centre, Smith was writing from New York, as an Australian expatriate. ${ }^{18}$ One could argue that the New Zealand equivalent might be Melbourne. With around 520,000 New Zealanders residing in Australia, it is, as sociologist Paul Spoonley describes, 'an important coming-of-age Pakeha ritual' to leave New Zealand on an overseas expedition. ${ }^{19}$ Ironically, in the 1992 catalogue for Pound's exhibition Little deceits - art crimes at the Michael Wardell Gallery in Melbourne, he includes a quotation from Charles Darwin on the topic of his departure from New Zealand in 1835: ' ... I believe we were all glad to leave New Zealand. It is not a pleasant place. ${ }^{20}$

\footnotetext{
${ }^{17}$ National Gallery of Victoria, "Visit," NGV, N.d., https://www.ngv.vic.gov.au/visit/.

${ }^{18}$ Terry Smith, "The Provincialism Problem," Journal of Art Historiography, no. 4 (June 2011): 4.

${ }^{19}$ Paul Spoonley, "Being Here and Being Pakeha," in Pakeha: The Quest for Identity in New Zealand, ed. Michael King (Auckland, NZ: Penguin Books, 1991), 148; Australian Bureau of Statistics, "Census Reveals a Fast Changing, Culturally Diverse Nation," ABS, June 27, 2017, http://www.abs.gov.au/ausstats/abs@.nsf/lookup/Media\%20Release3.

${ }^{20}$ Patrick Pound, Little Deceits - Art Crimes. (Melbourne, VIC: Michael Wardell Gallery, 1992), unpaginated.
} 
Around the time of Pound's departure, the art world in New Zealand was captivated by his eldest brother, Francis Pound, especially in the cultural milieu of the Auckland art scene. In early exhibition reviews of Pound's work, Francis Pound is frequently cited - leaving little space for discourse about Patrick Pound's actual work. In one review of an early solo exhibition in 1987, Ian Wedde wrote:

A rather different kind of ambiguity works through the surfaces of Patrick Pound's paintings at $33^{1 / 3}$ Gallery. Pound is in the final year at Elam, and he has the noted art critic Francis Pound for an elder brother. It may be these factors that make his surfaces correct, even academic. ${ }^{21}$

Wedde's implication here is that Patrick Pound's paintings are a reflection of Francis Pound's academic work, or at least influenced by that work. Another poignant example comes from Rob Taylor's review of the same exhibition, which dedicates the opening six paragraphs to a historiography of Francis Pound's work. $^{22}$ The first mention of Patrick Pound is as follows:

The stylistic preferences of this self-confessed art theorist come to mind at the exhibition at $33^{1 / 3}$ Gallery by his younger brother, an Elam student who for the moment seems typical of the Auckland version of the maniera post-moderne. ${ }^{23}$

This diminishment of Pound's practice to familial lineage by both Taylor and Wedde is reductive. As an art historian, Francis Pound did contribute texts that were important to the foundation of New Zealand's contemporary art-historical narrative: Frames on the Land: Early Landscape Paintings in New Zealand (1983) and, more recently, the Invention of New Zealand: Art \& National Identity 19301970 (2009). In the reviews of Patrick Pound's earlier exhibitions, the book Frames on the Land is frequently cited as foundational - regardless of the subject matter of those exhibitions. Taylor proves this once again in his review of Pound's exhibition Fragments and Fakes at Southern Cross Gallery in 1989. In the last paragraph of the review, he eventually cites Patrick Pound:

${ }^{21}$ Ian Wedde, "Prints That Buckle," Evening Post, November 11, 1987.

${ }^{22}$ Rob Taylor, "Witty Parodies and Sophisticated Cutouts," Dominion Post, November 17, 1987.

${ }^{23}$ Taylor, "Witty Parodies and Sophisticated Cutouts." 
But Francis Pound does have a younger brother, Patrick, who makes art. And Patrick Pound's present exhibition is about as convincing a construct of the sort of Killeen-based art pages that might be fictionally imagined from an invented brother of the theorist, if not from the theorist himself... ${ }^{24}$

These responses to Pound's work are common in earlier reviews. The exhibition reviewed by Taylor, Fragments and Fakes, is reflective of Pound's oeuvre in The Great Exhibition. The catalogue accompanying the exhibition is a compilation of quotes from theorists including Roland Barthes, Walter Benjamin, Rosalind Krauss and so forth. ${ }^{25}$ Francis Pound is not amongst them. So, Fragments and Fakes' entrenchment in art history is not through the influence of Francis Pound, but a result of Patrick's own adept knowledge of art history. It should be noted that Patrick Pound won the Senior Prize at the University of Auckland for both Art History and Fine Arts in 1986 and was awarded a Senior Scholarship for Art History as a result of his academic achievements. ${ }^{26}$ A strong knowledge and sense of art history, then, is imbued within Pound's work. For instance, one piece from Fragments and Fakes, titled Lives of the Artists (1989), references Giorgio Vasari's Lives of the Artists, a foundational art-historical text originally published in the sixteenth century. ${ }^{27}$ The site-specific work consisted of 153 books nailed to the wall in a grid formation, 17 across and nine down, a bricolage work. ${ }^{28}$ Pound installs his books in a grid formation, but without the usual constraints applied in later works or The Great Exhibition. In this thesis, I argue that while Pound's practice has evolved since graduating from Elam School of Fine Arts, traces of his early practice are present in his contemporary works - most notably, The Great Exhibition.

\footnotetext{
${ }^{24}$ Rob Taylor, "Frazer, Painting Minimalism and Quoting Romanticism," Dominion Post, December 20, 1989.

${ }^{25}$ Patrick Pound, Fragments and Fakes. (Wellington, NZ: Southern Cross Gallery, 1993), unpaginated.

${ }^{26}$ Patrick Pound, "Patrick Pound: Curriculum Vitae," Self-published material, 1996. unpaginated.

${ }^{27}$ Giorgio Vasari, "Life of Leonardo Da Vinci, Florentine Painter and Sculptor, 1452-1519," in Lives of the Artists, vol. I (London, UK: Penguin Books, 1987), 255-71.

${ }^{28}$ Pound, Fragments and Fakes, unpaginated.
} 
Undoubtedly, there are crossovers between the practices of Patrick and Francis Pound. In the catalogue accompanying the exhibition Headlands: Thinking Through New Zealand Art, staged at the Museum of Contemporary Art in Sydney in 1992, Christina Barton cohesively joins the two in the chapter 'Framing The Real: Postmodern discourses in recent New Zealand art. ${ }^{29}$ Barton summarises Francis Pound's hypothesis that, in an era of proliferating images, '... an art of images, an art whose images refer as much to images of the world as to the world' is 'an art about ways of seeing the world, as much as an art about the world.'30 This view was reflective of the postmodern condition that New Zealand inhabited in the 1980s. ${ }^{31}$ Barton claims that '[p]ostmodern practice in New Zealand selfconsciously negotiates that border territory between representation and reality.' 32 Accordingly, 'conceptual strategies' were developed by contemporary artists in response to this postmodern turn:

Found materials and images are frequently reissued, both in their original condition and modified, most notably mediated through photographic processes... Most especially, the image is now recognised as a surrogate, a standin for an inevitably absent reality. ${ }^{33}$

The integration of found objects into works of art was becoming an increasingly common conceptual strategy, used to explore the boundaries of art and its frame. Barton provides a useful link between the two Pound brothers, but argues that Patrick Pound has 'exploited the freedom offered by the removal of the frame.' 34 He is, after all, an artist who employs the Duchampian strategy of the 'found' object. The critical lens that Wedde and Taylor provide in the earlier reviews of Patrick Pound's exhibitions lacks awareness of these distinctions. While recognising the obvious impact that Francis Pound's art-historical discourse has

\footnotetext{
${ }^{29}$ Christina Barton, "Framing The Real: Postmodern Discourses in Recent New Zealand Art," in Headlands: Thinking Through New Zealand Art, ed. Mary Barr (Museum of Contemporary Art, Sydney, 1992), 173-84.

${ }^{30}$ Barton, 175.

${ }^{31}$ Ibid.

${ }^{32}$ Barton, 179.

${ }^{33}$ Ibid.

${ }^{34}$ Ibid.
} 
had on the wider New Zealand milieu, it clearly overpowers any alternative reading of Patrick Pound's work.

These links between Francis and Patrick Pound do exist but, again, they do not define Patrick Pound's practice. The same parallels are not established when it comes to other relatives. Another brother, Simon Pound, has also been involved in the arts, assisting the production of Simon Denny's Channel Document (2012), an installation consisting of a single-channel video and mounted works documenting the erosion of public media. Simon Pound also co-owns the clothing label Ingrid Starnes and worked at the advertising agency Saatchi \& Saatchi. Yet another brother, Thomas Newman Pound, practices as an assemblage and collage artist, with his most recent exhibition, Without Words: A Year Out Walking (8 March 22 April 2017), shown at the Gus Fisher Gallery in Auckland. Edward Hanfling's review of this exhibition in Art New Zealand did not cite the obvious affiliations to Francis or Patrick Pound. This was despite the exhibition being an assemblage of found objects imbued with a 'fake history,' which, according to Hanfling, is 'hot right now' in New Zealand. ${ }^{35}$ Patrick Pound's sister, Mary Newman Pound, is a mezzo-soprano opera singer who appeared in several of his earlier 1986 video works, including Mon [Coeur] S'ouvre a ta voix and Venus (both Ngā Taonga Sound \& Vision, Wellington, NZ). To add further layers to a potential crisis of identity, Patrick Pound's partner, Juliet Frizzell, is the daughter of New Zealand artist Dick Frizzell. Alongside this, Francis Pound's partner Sue Crockford, operated the Sue Crockford Gallery from 1985 until 2012 and exhibited Patrick Pound on two occasions - in 1991 and 1994. The names Crockford, Frizzell and Pound are all synonymous with the New Zealand art scene. As someone who shares an unusual last name with several family members who operate in the art world, I can understand the issues here. With Pound's identity so firmly affixed in New Zealand's insular art history, his eventual invention of multiple personae and pseudonyms forms a commentary on the narratology of art history itself and could

\footnotetext{
${ }^{35}$ Edward Hanfling, "Exhibitions: Thomas Newman Pound," Art New Zealand, 2017, 37.
} 
be seen as a form of both escapism and diffusion. Of course, these names mean very little outside of New Zealand or in Australia - the ultimate escapism.

Despite being based in Melbourne, Pound continues to exhibit semi-regularly in New Zealand, primarily through his dealer galleries. These include Hamish McKay in Wellington and the Melanie Roger Gallery, formerly the Anna Bibby Gallery, in Auckland. Pound's last solo exhibition in New Zealand was at Hamish McKay in 2009, but more recently a group show was staged at Victoria University of Wellington's Adam Art Gallery in 2016. Pound's work was shown alongside that of Walker Evans and Sherrie Levine. During the last decade, Pound has increasingly been exhibiting in Australian galleries, through his dealers Grant Pirrie (stylised GRANTPIRRIE) and Stills Gallery (now defunct), as well as major public institutions. Some notable examples include Pound's exhibition The Gallery of Air (23 October 2013 - 23 March 2014), staged in the NGV International wing, ironically in a space that had previously been dedicated to photography but disestablished that year. The Photograph and Australia, discussed earlier, was presented at AGNSW. More recently, Pound staged a sitespecific exhibition at the 2018 Adelaide Biennial of Australian Art: Divided Worlds (3 March - 3 June 2018) titled The Point of Everything. While Pound's work has been conspicuously absent from major New Zealand art institutions, a forthcoming show, Patrick Pound: On Reflection, will be staged between 11 August and 4 November 2018 at City Gallery Wellington, too late for consideration in this thesis. Following a similar format to Patrick Pound: The Great Exhibition, this show will be the first survey of his work within a New Zealand context and will draw on Te Papa Tongarewa's national collection.

In 2011, Pound completed a PhD in Art History at the University of Melbourne. His thesis explored the 'problem of photographs in relation to texts,' and how '[n] arrative contexts press these photographers and their photographs to work 
differently.' ${ }^{36}$ Pound's thesis analyses how documentary photography functions within different narrative contexts within books, creating 'a text and image nexus' between fact and fiction. ${ }^{37}$ His research primarily focused on the relationships between Alvin Langdon Coburn and Henry James, as well the interaction between Walker Evans and James Agee. ${ }^{38}$ As Susan Sontag noted in On Photography, with reference to the Walker Evans photographs in James Agee's Let us now Praise Famous Men (1941): 'The quotations have nothing to do with the photographs but are correlated with them in an aleatoric, intuitive way.' ${ }^{39}$ Sontag writes that the 'force of its historical argument is the force of collage.' ${ }^{40}$ This is one way of viewing Pound's practice - as an aleatoric exercise of collage. Pound's doctoral thesis is building on years of his own practice of mixing text with photographs. His interrogation of how text can function to contradict or complicate the image is visible in both his practice and his thesis. An obvious example is the image of Lester Gaba that is made to signify Patrick Pound [Fig. 1].

To explore Pound's relationship to biography and authorship, fact and fiction, I survey several key theorists in Chapter One. Firstly, we must establish what is at stake in any attempt to define the author. By looking at Rosalind Krauss's 'Photography's Discursive Spaces' (1982), Griselda Pollock’s ‘Artists Mythologies and Media Genius, Madness and Art History' (1980) and Roland Barthes' 'The Death of the Author' (1967) we can establish the importance of the author within the art market and wider culture. This will be demonstrated through a case study of Pound's C.V.-a work in progress, which parodies the art world's obsession with the artist's biography.

\footnotetext{
${ }^{36}$ Patrick Pound, "Significant Documents: Photography and Narrative from Alvin Langdon Coburn's and Henry James's New York Edition (1907-9), to Walker Evans's and James Agee's 'Let Us Now Praise Famous Men' (1941, 1960)" (2011), http://minervaaccess.unimelb.edu.au/handle/11343/36628.

${ }^{37}$ Pound, "Significant Documents."

${ }^{38}$ Ibid.

${ }^{39}$ Sontag, On Photography, 73.

${ }^{40}$ Sontag, 73.
} 
I explore postmodern ideologies of authorship and Pound's exhibition, INTERNATIONAL (1994), as an example of postmodern practice. Historically, the interrogation of the author can be observed in Marcel Duchamp's found works, which operate to destabilise aura, autonomy and authorship. ${ }^{41}$ Duchamp inhabited multiple pseudonyms over the course of his life and his practice has come to inform my understanding of Pound. Duchamp's theorisation of the 'readymade' can be applied to some of Pound's earlier works including Summer Holiday 1962 (Ngā Taonga, Wellington). Building on this discussion, I will use Geoffrey Batchen's Each Wild Idea: Writing, Photography, History (2000) to consider the historical relationship between photography and authorship, seeking to contextualise Pound's gravitation towards the photographic medium.

Australian artist and art historian Ian Burn draws these threads together with his meditation on art history and the artist's biography in his essay 'Is art history any use to artists?' (1985). Burn provides an impetus to discuss the instability of meaning within works of art, which we can then apply to The Great Exhibition. Of note here is Georges Perec and the OuLiPo group. OuLiPo, an acronym for OUvroir de LIttérature POtentielle, roughly translates from French as 'Workshop of Potential Literature'; its 1960 manifesto described its activities as 'writing under constraint.' ${ }^{42}$ Pound's interest in the OuLiPo group of writers is a central tenet in understanding The Great Exhibition. The idea of categorising and constraint are useful mechanisms to apply to both the exhibition and Pound's wider practice. A key member of the OuLiPo group, Georges Perec, provides a theoretical cornerstone with which to decipher Pound's work and will guide my analysis in Chapters One and Three.

${ }^{41}$ Elena Filipovic, The Apparently Marginal Activities of Marcel Duchamp (Cambridge, MA; London, UK: The MIT Press, 2016), 2.

${ }^{42}$ Roland Greene et al., eds., "Oulipo," The Princeton Encyclopedia of Poetry and Poetics: Fourth Edition (Princeton, NJ: Princeton University Press, 2012), 987, http://www.jstor.org/stable/j.ctt2tt8jz.23. 
In Chapter Two, I will establish a definition for 'vernacular photography,' which will be guided by the work of Geoffrey Batchen. The term 'vernacular photography' has come to inhabit a plethora of identities including the term 'snapshot.' It is, therefore, important to consider Pierre Bourdieu's theorisation of the snapshot and the position it occupies in everyday life, as discussed in Photography: A Middle-Brow Art (1990). Roland Barthes' influential text, Camera Lucida (1981), will guide my understanding of our own relationship with photographs in this chapter.

In order to contextualise the use of found vernacular photographs in The Great Exhibition, I explore works by Erik Kessels and Joachim Schmid to better understand how these practices relate to those of Pound. I will highlight how Pound is re-imagining and repeating some of their key concepts but pushing them further. I do not intend to argue that his use of vernacular photographs in The Great Exhibition is entirely original, but the methodology by which they have been collected and the breadth of the system in which they are categorised and displayed is distinct.

I explore how archives and collections are implicitly related to the functions of photography - as a means to preserve memory and to confirm life and death. I hope to understand how the concept of the archive relates to The Great Exhibition and its use of vernacular photographs. Pound references the practices of Duchamp throughout The Great Exhibition. Duchamp's conceptualisation of the Boite-envalise (1935-1941) is important here as it operates as a historical parallel to The game of things (2016) in The Great Exhibition.

Through my analysis in Chapter Three, I demonstrate how Pound functions as both an artist and curator for The Great Exhibition. I will explore how his methodology of curation is positioned within a history of 'artists-as-curators,' which includes Edward Steichen's The Family of Man (1955) and Fred Wilson's Mining the Museum (1992-1993). I argue that the success of The Great Exhibition 
as an artwork is premised on the capability of Pound, the collector, to connect and curate his multifarious ideas.

The website eBay is characterised by its employment of a series of algorithms, all of which enable seamless consumption for users of the website. Pound uses eBay to develop ideas and connect these with objects. To understand how eBay informs and influences Pound's practices of collecting and curating which are evident in The Great Exhibition, I will undertake a short practical research exercise in its use. Perec's discussion of 'Great Exhibitions,' in Thoughts of Sorts (1985), offers up an algorithmic approach to the creative decision-making that can be directly related to Pound's practice. Pound references Perec, in The Great Exhibition, in a work titled Thoughts-of-sorts (2016-17) - a web-based algorithm, again made in collaboration with artist Rowan McNaught. Thoughts-of-sorts matches quotes to images with sometimes incongruous results, such as the propensity to return to the term 'scissor,' as if the programme has some sort of self-awareness that it is a form of digital collage.

Georges Perec's Life: A User's Manual (1978) informs my analysis of The Great Exhibition in Chapter Three. The book is constructed as a literary puzzle, focusing particular attention on matrixes, grids and lists and the documentation of objects from the minutiae of life. Pound writes that visitors to The Great Exhibition 'play their part in trying to think through how each thing fits in the puzzle that I have set. ${ }^{43}$ This is demonstrated in Gallery Six of The Great Exhibition, which displays a 'matrix of connections' between Pound's own collection of vernacular photographs and the NGV's collection:

This installation also reflects the way in which Pound searches on the internet, and the ways in which the internet leads us from one thing to another via

${ }^{43}$ Maggie Finch, "A Conversation: Patrick Pound and Maggie Finch," in The Great Exhibition, ed. Mark Gomes (Melbourne, VIC: National Gallery of Victoria, 2017), 13. 
algorithms. The room is a visual representation of what Pound describes as 'thinking through things. ${ }^{44}$

Pound's use of grids, matrixes and, ultimately, algorithms is a guiding mechanism throughout his practice and is not only confined to The Great Exhibition. An algorithm, in its essence, is a procedure or a set of processes, usually aided by a computer-based application. If we consider an algorithm as process-based, we can position Pound as an artist who structures his collecting, categorisation and curatorial practice using an algorithm-like process. The Great Exhibition offers us 'intersections' and 'matrixes,' connecting one photograph to another; to a piece from the NGV's collection; to a mask of Donald Trump - all arranged and categorised using OuLiPian logic. Websites like eBay use algorithms to suggest things to buy based on previous purchases, which is analogous to how Thoughtsof-sorts operates as a conceptual process.

Pound's research-based art practice relies on ideas and objects. For him, there is 'no ideas but in things,' a passage frequently cited by Pound, which he has borrowed from poet William Carlos Williams. ${ }^{45}$ Pound goes on to qualify that: 'I was never quite sure exactly what he meant, but I knew it applied to my work.' 46 Sontag claims that a visual conceptualisation of language, for poets like Williams, was 'poetry's commitment to the concreteness and autonomy of the poem's language,' to 'parallel photography's commitment to pure seeing.' ${ }^{47}$ These connections between Williams and visual language can also be applied to Pound. They are best articulated by Sontag:

Both imply discontinuity, disarticulated forms and compensatory unity: wrenching things from their context (to see them in a fresh way), bringing things

\footnotetext{
${ }^{44}$ Maggie Finch, "Patrick Pound: The Great Exhibition Artwork Labels" (National Gallery of Victoria, 2017), 264, https://www.ngv.vic.gov.au/wpcontent/uploads/2016/09/PatrickPound_ArtworkLabels.pdf.

${ }^{45}$ Finch, "Patrick Pound: The Great Exhibition Artwork Labels," 260.

${ }^{46}$ Pound, The Space Museum Guide / Collected Works: Telling Things, 9.

${ }^{47}$ Sontag, On Photography, 96.
} 
together elliptically, according to imperious but often arbitrary demands of subjectivity. ${ }^{48}$

The use of literature to establish an interpretive framework is of interest. Not only does Pound draw on poets like William Carlos Williams, or writers like James Agee, but he also pays homage to the literature that has informed his practice in The Great Exhibition.

As an artist, Pound traverses a range of media and methodologies in his works, from film, photography, painting, collage, algorithms and collecting to curating. The constant throughout Pound's practice, however, is his effort to interrogate the narratives of objects by displacing and re-contextualising them into new settings. The Great Exhibition is demonstrative of this. Pound's practice questions the notion of the author, presenting us with vernacular photographs as his own products. Here, 'things' are appropriated by Pound to stand in for his ideas about collecting, photography and authorship. The Great Exhibition is emblematic of a practice that Pound has been developing and refining over decades. This exhibition, then, demonstrates the complexity and multiplicity of Pound's practice, exemplifying the interconnectedness of his thinking and his use of an algorithmic approach to collecting, curating and categorisation.

${ }^{48}$ Sontag, On Photography, 96. 


\section{Chapter One: Authorship/Meaning}

\section{He has developed a fiction about his life and to destroy that fiction would tear down the whole castle that he's built of his illusions... ${ }^{1}$ \\ Clifford Irving in $F$ for Fake}

This chapter establishes a framework with which to assess Patrick Pound's relationship to authorship. First, I develop a working definition of the term 'author' and explore the notion of 'authorship.' Rosalind Krauss's essay, 'Photography's Discursive Spaces,' and Roland Barthes' 'Death of the Author' informs my discussion of these concepts while Griselda Pollock's 'Artists Mythologies and Media Genius, Madness and Art History' explains how biographical narratives are constructed.

I explore Pound's motivation to destabilise the author, which is not only evident in Patrick Pound: The Great Exhibition but also in his wider practice. Pound's engagement with biography and authorship is analysed primarily through his work C.V.-a work in progress (n.d.). His generative practice has consistently placed pressure on the notion of the author and postmodern ideologies of authorship pervade his work. This is exemplified in Pound's exhibition of appropriated reproductions, INTERNATIONAL (1994).

It is also important to position authorship in relation to photography and its wider art-historical context. The multifarious nature of photographic authorship is explored by Geoffrey Batchen in his work Each Wild Idea: Writing, Photography, History (2000). The histories of photographic authorship provide a better understanding of why photography, particularly vernacular photography, has generally been excluded from art-historical discourses and have been afforded very

${ }^{1}$ Orson Welles et al. (dirs.), F for Fake, (Germany, Planfilm, 1973). 
little value in the art market. These exclusions have, however, enabled Pound to purchase inexpensive photographs from eBay for The Great Exhibition.

A current flows throughout Pound's practice: the blurring of narratives and shifting of boundaries relating to the author. His fictional identities offer up self-reflections on the art-historical practice of ascribing narratives to artists. A parallel might be found in Orson Welles' filmic essay, F for Fake (1973), which exemplifies how shaky the foundations of fact and fiction can be in any biography. The film opens with Welles dressed, as he describes himself, as a charlatan. Welles prophesises that '[a]lmost any story is some kind of lie,' as he performs an illusion, or magic trick, for a young boy. ${ }^{2}$ This meta-documentary considers the art forger Elmyr de Hory, who successfully faked thousands of artworks over the course of his career. Elmyr's biographer, Clifford Irving, was also a forger - known for writing the hoax biography of Howard Hughes. Welles, too, engages in forgery:

I did promise that for one hour I'd tell you all the truth. That hour, ladies and gentlemen, is over. For the past seventeen minutes, I've been lying my head off. The truth, and please forgive us for it, is that we've been forging an arts story. As a Charlatan of course, my job was to try to make it real. Not that reality has anything to do with it. ${ }^{3}$

Like Welles, Elmyr and Irving, Pound deliberately 'tampers with truth. ${ }^{4}$ He writes his own biographies using different pseudonyms, practically demonstrating the flaws in the practice of ascribing biographical narratives to artists. F for Fake is a metaphor for my argument that Pound blurs fact and fiction, interweaving alternative narratives together to interrogate authenticity and authorship.

\section{Defining the Author}

What does it mean to be an author? What are the implications of authorship? In her essay, 'Photography's Discursive Spaces,' Rosalind Krauss suggests that the term

\footnotetext{
${ }^{2}$ Welles, $F$ for Fake.

${ }^{3}$ Ibid.

${ }^{4}$ Hill, "Extracts from: The Encyclopaedia of Photofictions," 20.
} 
'artist' implies more than just a role of author, as an artist has to 'go through certain steps to earn the right to claim the condition of being an author.' ${ }^{5}$ She compares Timothy O'Sullivan's photograph Tufa Domes, Pyramid Lake, Nevada (1868) with the lithographic copy created for publication. ${ }^{6}$ Krauss notes how the two images operate within different discursive spaces: 'the lithograph belongs to the discourse of geology' whereas O'Sullivan's photograph has been read within an 'aesthetic discourse. ${ }^{7}$ O'Sullivan's photograph is able to be verified within this aesthetic discourse because his photograph is 'a representation of what could be called exhibitionality.' Institutions, such as galleries and museums, play a critical role in the arbitration and regulation of artists' career progressions through their own authorial status: 'Modern art history is in that sense a product of the most rigorously organized nineteenth-century space of exhibition: the museum.' 8

Krauss discusses how the 'assimilation' of Eugène Atget's archive of 10,000 works into a unified aesthetic discourse was undertaken by constituting an oeuvre around his work. ${ }^{9}$ She argues that the title of 'artist' pertains to the stylistic evolution that artists present through exhibitions and is made evident in the curriculum vitae (C.V.). ${ }^{10}$ The artist's C.V. becomes a signifier of that stylistic evolution and place within this aesthetic discourse. Thus 'the concept artist with its correlative notion of sustained and intentional progress' is assessed; it is what we 'give the term career. ${ }^{11}$ An artist's career is evaluated for the 'coherence and meaning that will unfold through the collective body of work so produced, thus constituting the unity of an oeuvre. ${ }^{12}$ Krauss argues that the attempt to abandon the 'aesthetically derived categories of authorship, oeuvre, and genre [...] obviously amounts to an attempt to maintain early photography as an archive and to call for the sort of archaeological

\footnotetext{
${ }^{5}$ Rosalind Krauss, "Photography's Discursive Spaces," in The Originality of the Avant-Garde and Other Modernist Myths (Cambridge, MA: MIT Press, 1985), 142.

${ }^{6}$ Krauss, "Photography's Discursive Spaces," 131.

7 Krauss, 132-33.

8 Krauss, 141.

${ }^{9}$ Krauss, 144.

${ }^{10}$ Krauss, 141-42.

${ }^{11}$ Krauss, 142.

${ }^{12}$ Ibid.
} 
examination of this archive... ${ }^{13}$ While Atget has been evaluated on his stylistic evolution within the archive, Pound has evaded evaluation because his archive of photographs is not authored by himself. We can, therefore, consider that The Great Exhibition is only able to be read within an aesthetic discourse because it comes under the aegis of the NGV. We can assume that the 'creator,' Patrick Pound, is also the author of the exhibition because the exhibition is described as a retrospective.

While Patrick Pound: The Great Exhibition includes his name in the title [Fig. 5], the exhibition is co-authored with Maggie Finch, a curator at the NGV. Therefore, Finch and the NGV are also authors of the exhibition. With over 300 items from the NGV's collection absorbed into Pound's site-specific installations, and an absence of public acknowledgement of his co-authors, it appears as if Pound has here claimed the 'condition' of the author. By integrating the collection into The Great Exhibition, this artwork's interdependent relationship with the NGV is cemented in perpetuity. Pound's use of 'found' materials is another example of authorship being interrogated throughout his practice. The 4,000 vernacular photographs in The Great Exhibition, most of which were sourced by Pound through the online auction website eBay, provide another example of Pound overriding authorship from the original creators of those objects. The material becomes Pound's by virtue of its display under his name and sanctioning by the museum.

The construction of biographical narratives to discover the 'truth' of the author is referred to by Griselda Pollock as the psychobiographical model. ${ }^{14}$ She says it is problematic in art history and cites the example of Vincent van Gogh, who is commonly understood in relation to his 'madness' and 'genius,' a narrative trope that has enveloped his career. ${ }^{15}$ Even Roland Barthes writes that van Gogh's

\footnotetext{
${ }^{13}$ Krauss, $149-50$.

${ }^{14}$ Griselda Pollock, "Artists Mythologies and Media Genius, Madness and Art History," Screen 21, no. 3 (Fall) (1980): 62.

${ }^{15}$ Pollock, "Artists Mythologies and Media Genius, Madness and Art History," 60.
} 
madness is cited as an explanation of his work. ${ }^{16}$ The retrospective or survey exhibition is an archetypal example of art histories constructed around the individual as a genius author. ${ }^{17}$ How, then, do we interpret The Great Exhibition as a survey of Pound's practice? In the catalogue for The Great Exhibition, Geoffrey Batchen ascribes a high-functioning level of madness to him:

[Pound] has happily given in to the impulse and converted his surrender, that neurotic desire to acquire things [...] Through his act of arranging and displaying these things (as opposed to simply hoarding them), Pound choreographs a tricky tension between order and excess, reason and madness, classification and idiosyncrasy. ${ }^{18}$

Here Batchen applies the terms 'neurotic' and 'madness' to describe Pound, and there is a sense of accuracy in the statements. The artist deploys a minimum of three storage units for his collections at any one time, so there is an understandable desire to characterise such excess as madness. Yet, as Batchen points out, there is an 'order' to the 'excess' and 'reason' to the 'madness.' To that end, a parallel cannot be drawn between Pound's practice and mindless hoarding.

The trope of the artist's narrative, which Pollock cites as emblematic of retrospective and survey exhibitions, is also emblematic of the art historian's desire to construct an art-historical narrative as la vie romancée - the romanticised life of an artist. ${ }^{19}$ Pollock notes:

Art and the artist become reflexive, mystically bound into an unbreakable circuit which produces the artist as the subject of the art work and the art work as the means of contemplative access to that subject's 'transcendent' and creative subjectivity. ${ }^{20}$

\footnotetext{
${ }^{16}$ Roland Barthes, "Death of the Author," in Image, Music, Text, trans. Stephen Heath (New York, NY: Noonday Press, 1988), 143.

${ }^{17}$ Pollock, "Artists Mythologies and Media Genius, Madness and Art History," 58.

${ }^{18}$ Geoffrey Batchen, "Keepers: Patrick Pound and the Art of Collecting," in The Great Exhibition, ed. Mark Gomes (Melbourne, VIC: National Gallery of Victoria, 2017), 35.

${ }^{19}$ Pollock, "Artists Mythologies and Media Genius, Madness and Art History," 67.

${ }^{20}$ Pollock, 59.
} 
Pound disrupts the romanticised version of the artist 'mythically bound' to a linear narrative. Pollock argues that the elevation of the author serves an 'economic function' as a 'means by which art history services the art market. ${ }^{21}$ Locating and securing the position of an artist within art history is, therefore, important to the art market. Pollock notes that ' $[\mathrm{t}]$ he preoccupation with the individual artist is symptomatic of the work accomplished in art history.' 22 The positioning of an artist within art history contributes to determining the price an artist's work can achieve. As Pollock states: '[t]he economic value of a painting depends also on the status of its author.'23

An archetypal example of la vie romancée is the narrative surrounding Vincent van Gogh. ${ }^{24}$ Ironically, the exhibition Van Gogh and the Seasons was on display (28 April - 12 July 2017) at the NGV at the same time as Pound's The Great Exhibition, allowing me to compare the narratives conveyed in each exhibition. Van Gogh and the Seasons channelled visitors into a room to watch a biopic about van Gogh before entering the exhibition. The film traversed van Gogh's life and how it is reflected in his works, before concluding with the topic of his suicide accompanied by a visual transition to a sun setting. ${ }^{25}$ By contrast, The Great Exhibition provided very little information about Pound. The exhibition text only once refers to Pound's life, noting that he is 'Melbourne-based' and 'New Zealandborn. ${ }^{26}$ Fixing a biographical narrative to artists, in this case with van Gogh, can be seen as a means to identify the 'truth' of an artist and their work and does serve a function. ${ }^{27}$ As Pollock would agree, the tumultuous video of van Gogh's own internalised Seasons are "the discursive structures through which such ideologies

${ }^{21}$ Pollock, 63.

${ }^{22}$ Pollock, 58.

${ }^{23}$ Pollock, 63.

${ }^{24}$ Pollock, 67.

${ }^{25}$ NGV Melbourne, VAN GOGH AND THE SEASONS - The Exhibition Film, YouTube, accessed July 30, 2018, https://www.youtube.com/watch?v=Qa3f5FMf8zw\&feature=youtu.be.

${ }^{26}$ Finch, "The Great Exhibition Artwork Labels," 2017, 17.

${ }^{27}$ Pollock, "Artists Mythologies and Media Genius, Madness and Art History," 95. 
are produced, the literature of art, the narrative practices of art history. ${ }^{28} \mathrm{By}$ establishing a romanticised myth of the artist, we 'sever art and artist from history,' locating them within a framework of interpretation tied to biography. ${ }^{29}$ Griselda Pollock suggests that such discursive practices produce a hegemonic narrative that secures the artist as an individual creative genius. ${ }^{30}$

To that end, Pound is an artist who disrupts the archetypal vie romancée narrative. Pound's work is concerned with the very nature of the production of art-historical narratives, thwarting its construction over the course of his career. The use of Lester Gaba's photograph to stand in for Pound in exhibition catalogues is typical of his practice [Fig. 1]. In the exhibition catalogue, Patterns of Intentions, published in conjunction with Artspace in 1998, Pound writes: 'It is a little known fact that my grandfather's brother was Ezra Pound. In our family it was always seen as poor form to bathe in any reflected glory. ${ }^{31}$ Of course, Ezra Pound is no relation to Patrick Pound but this statement functions as its own mythology, diverting attention away from his biography. It serves to displace Pound from a New Zealand arthistorical narrative, shifting him in relation to Ezra Pound's literary narrative. To add to this, there is little biographical evidence in existence about Patrick Pound. The literature largely exists in relation to his practice.

Roland Barthes' seminal text, 'The Death of the Author,' written in 1967 and published in English in Image-Music-Text (1977), also interrogates the concept of the author's connection to the text. ${ }^{32}$ Barthes argues that one of the motivations to grant an authoritative status to the 'Author' is a hangover from 'capitalist ideology, which has attached the greatest importance to the "person." 33 This fixation with ascribing meaning in relation to the Author is problematic for Barthes:

\footnotetext{
${ }^{28}$ Pollock, 95.

${ }^{29}$ Pollock, 65.

${ }^{30}$ Pollock, 96.

${ }^{31}$ Robert Leonard and Kelly Carmichael, eds., Patterns of Intention. (Auckland, NZ: Artspace, 1998), 16.

${ }^{32}$ Author has been capitalised with reference to "The Death of the Author" to reflect text.

${ }^{33}$ Barthes, "The Death of the Author," 143.
} 
Once the Author is removed, the claim to decipher a text becomes quite futile. To give a text an Author is to impose a limit on that text, to furnish it with a final signified, to close the writing. Such a conception suits criticism very well, the latter then allotting itself the important task of discovering the Author (or its hypostases: society, history, psyche, liberty) beneath the work: when the Author has been found, the text is 'explained' - victory to the critic. ${ }^{34}$

The dominance of the author or artist that plays out in art-historical writing is therefore limiting. Barthes is of the view that focussing on the author closes the writing to alternative interpretations, as we 'know now that a text is not a line of words releasing a single 'theological' meaning. ${ }^{35}$ Rather, a text is 'a tissue of quotations drawn from the innumerable centres of culture' and can be understood in different contexts and through alternative cultural codes. ${ }^{36}$ The idea that a work must operate in a certain way ignores the agency of the reader. For Barthes, 'the birth of the reader must be at the cost of the death of the Author., 37

\section{Curriculum Vitae - A Case Study of Deceit}

In the introduction to this thesis I outlined what Krauss would term Pound's Curriculum Vitae. This was provided as the contextual underpinnings of Pound's practice (ironically) like that of a C.V. It is also to provide a record, given his consistent fabrication of evidence, as I will demonstrate here. Pound has been interrogating the fluidity of the artist's biography and the implications of authorship since the 1980s through his own inhabitation of fictional identities and use of pseudonyms. This practice is best exemplified in his evolving work C.V.-a work in progress (n.d.), which acts to intervene in the art world's 'obsession with identity. ${ }^{38}$ While it is important to define who Pound is for the purposes of a research thesis, it is also imperative to understand how biography can be a blunt

\footnotetext{
${ }^{34}$ Barthes, 147.

${ }^{35}$ Barthes, 146.

${ }^{36}$ Ibid.

${ }^{37}$ Barthes, 148.

${ }^{38}$ Patrick Pound, "C.V.-A Work in Progress," Cabinet Magazine, December 20, 2017, http://www.cabinetmagazine.org/issues/18/pound.php.
} 
tool to interpret the work of any artist. I will demonstrate how Pound resists the biographical model through his use of parody and irony to disrupt the imposition of a cohesive narrative being ascribed to his practice.

C.V.-a work in progress invokes a wider discussion about artists and identity. Artists catalogue their career through a Curriculum Vitae (C.V.), documenting their achievements by listing solo exhibitions, group shows, awards and academic qualifications. This accumulation of information that is the C.V. will, supposedly, demonstrate an artist's creative pedigree through the illumination of their careers and trajectories. Pound, however, started preparing C.V.-a work in progress in the 1990s as a 'parody of the growing artists' mania for curricula vitae and the art world's literal obsession with identity. ${ }^{39}$ This project infused the fake with the real, with 'the real' occupying a space somewhere on the continuum:

By continuing the project for so long, and at such expense, I was aiming for a saturation of stories; for a fiction convincing in its thoroughness, if not its facts. Gradually I inserted a variety of half-truths and outright fabrications into this vanity system. ${ }^{40}$

Pound describes C.V.-a work in progress as a 'home project' consisting of a collection of awards and accolades - some of dubious origin. ${ }^{41}$ For instance, in 2003, Pound paid to become a member of the International Biographical Centre, which is based in the United Kingdom. ${ }^{42}$ As a result, he was awarded the right to include the letters F.I.B.A. after his name, an acronym for Fellow of the International Biographical Association. ${ }^{43}$ Soon after, in 2004, Pound was awarded the title of International Artist of the Year by the Association and received a sash and plaque to commemorate this achievement. It should be noted here that the Western Australian State Government released a warning on their website stating that the International Biographical Centre was a 'scam,' targeting 'gullible

\footnotetext{
${ }^{39}$ Pound, "C.V.—A Work in Progress."

${ }^{40}$ Ibid.

${ }^{41}$ Ibid.

${ }^{42}$ Ibid.

${ }^{43}$ Ibid.
} 
people. ${ }^{44}$ The warning continues: 'WA [Western Australia] ScamNet would advise people to consider carefully how much they are willing to pay for an ego boost which isn't necessarily worth the paper it is written on. ${ }^{45}$ Pound, however, is also the scammer here, as he falsified his identity at the International Biographical Centre. In its publications we can see that Pound uses the photograph of Lester Gaba to represent himself, essentially scamming the scam [Fig. 6]. After being awarded International Artist of the Year, Pound was satisfied that the collection of awards was complete and 'closed the collection' for C.V.-a work in progress. ${ }^{46}$ It will, however, never really be 'closed' because C.V.-a work in progress continues to permeate his archives and documentation.

Another example of the extent to which Pound is prepared to go in order to build a narrative of his choosing can be seen in the exhibition catalogue for 'The Tailor's Library (1996),' which includes two short essays written by Ian Smith Jnr and Ray Fox. ${ }^{47}$ Their biographies appear at the back of this small booklet, accompanying a short biography of Pound [Fig. 7]. These biographies, however, are forgeries. Just as Pound uses the photograph of Lester Gaba in place of his own, he has also falsified the biographies of Ian Smith Junior and Ray Fox. The photograph of Ian Smith Jnr is actually a photograph of Lee Catterall, the author of The Great Dali Art Fraud and other deceptions (1992), while the photograph of Ray Fox is of Michael Heyward, who wrote The Ern Malley Affair (1993). The added layers of parody here are that Catterall writes about art fraud and Heyward about the fictitious Australian poet, Ern Malley. The end-sheet of The Tailor's Library provides us, perhaps, with a summation of Pound's intention. It is inscribed with the following quote by Oscar Wilde: 'What would you say about a young man who had a strange theory about a certain work of art, believed in his theory, and

\footnotetext{
${ }^{44}$ Western Australia Government, "Scamnet," WA Scamnet, n.d., http://www.scamnet.wa.gov.au/scamnet/Scam_types-Buying_or_selling-False_billingInternational_Biographical_Centre.htm.

${ }^{45}$ Western Australia Government.

${ }^{46}$ Peter Hill, “An Encyclopaedia of Patrick Pound's Superfictions," Photofile 91 (December 2010): 62 .

${ }^{47}$ Pound, The Tailor's Library, unpaginated.
} 
committed a forgery in order to prove it? ${ }^{\prime 48}$ Is Pound suggesting, perhaps, that the expert cannot be trusted? This is a theme that Orson Welles emphasises in $F$ for Fake, claiming that ' $[\mathrm{e}] \mathrm{xperts}$ are the new oracles ... They speak to us with the absolute authority of the computer ... And we bow down before them. They're god's own gift to the faker.' 49 The experts in The Tailor's Library are fakes constructed by Pound purely for the purpose of disrupting our complacency as readers.

Pound's interrogation of authorship includes an examination of the role of the art historian, whose function is to ascribe cultural relevance to the artist. With his knowledge of fine arts and art history he is able to collapse the gap between both roles. This amalgamation is realised when Pound inhabits multiple identities such as Ian Smith Jnr and Ray Fox. He writes that his interest in pseudonyms and alternative identities began early on in his career:

My interest in fictional identities began in the early 1980s, when I faked a series of letters to the editor of a New Zealand newspaper. On one occasion, I succeeded in having 14 published in just two days; they were all regarding a music review and took all sides. Since 1989 I have written on and around my artwork under a collection of pseudonyms. Beginning with an ersatz interview in my first catalogue, Fragments and Fakes, I have affectionately parodied critical mannerisms, while saving money on author's fees. ${ }^{50}$

The use of different personae has, however, come to permeate Pound's practice, as the following list of fakes appearing in previous works demonstrates:

... Monica Smith (Monica being a pun on moniker), Dr Gerry Ford (Ford, Gerryforgery), the curator Ian Smith Jr. (Ian Smith Jr. being the son of Ian Smith, that is, Smith's son Ian, curator; that is, Smithsonian curator). Ray Fox is an allusion to Reynard the fox, that trickster of medieval marginalia. Under the name Simon Dermott, I have written several reviews of books, from Ralph Rugoff's Scene of the Crime catalogue to a crime scene photographer's guide. Simon Dermott was the specialist in museum security and the detecting, tracing, and exposing of forgeries from the film How to Steal a Million. ${ }^{51}$

\footnotetext{
${ }^{48}$ Pound, The Tailor's Library, unpaginated.

${ }^{49}$ Welles, $F$ for Fake.

${ }^{50}$ Pound, "C.V.- A Work in Progress."

${ }^{51}$ Ibid.
} 
This list is by no means exhaustive but it does demonstrate Pound's propensity to inhabit pseudonyms to emphasise a point.

The practice of Marcel Duchamp is pertinent in any discussion about pseudonyms and Patrick Pound. The fluidity of identity demonstrated by Duchamp became manifest in Fountain (Fontaine) (1917, reproduced 1964: Tate Modern, UK), when he signed the work as 'R. Mutt.' Duchamp inhabited several pseudonyms but one of the most prominent was Rrose Sélavy, which he used to sign many of his works. ${ }^{52}$ Rosalind Krauss writes that "the very name he uses for his "double" projects a strategy for infecting language itself with a confusion in the way that words denote their referents. ${ }^{53}$ Rrose Sélavy is a homophone, being both a proper name and, on closer examination, a sentence. Originally Duchamp spelled Rose with a single $\mathrm{R}$, so when the name is spoken it is pronounced 'Rose, c'est la vie,' meaning 'Rose, that is life.' However, with the addition of an extra R, the French pronunciation of Rrose Sélavy becomes 'Eros, c'est la vie' and changes the meaning to 'Eros, that is life.' Verbal puns are used by Pound to develop personae such as 'Dr Ford, Gerry,' reminding us of the long history that cohabitation of multiple identities by artists and authors sits within.

Pound's awareness of the trope of the artist's narrative is evident from early on in his career, when he challenged the very nature of the biographical production of artists' catalogues. In extracts from a library (1994: Sue Crockford Gallery), Pound draws our attention to the conventions of catalogue writing. He considers how, for instance, catalogues generally start with a 'biographical anecdote' about the artist, move through to a 'related quote from a figure noted in the field' and may conclude with 'giving the artist the last word. ${ }^{54}$ Pound reflects on this pattern of writing

\footnotetext{
${ }^{52}$ Thomas Girst, The Duchamp Dictionary (London, UK: Thames \& Hudson, 2014), 148.

${ }^{53}$ Rosalind Krauss, "Notes on the Index: Part 1," in The Originality of the Avant-Garde and Other Modernist Myths (Cambridge, MA: MIT Press, 1985), 200.

${ }^{54}$ Patrick Pound, Patrick Pound: Extracts from a Library. (Auckland, NZ: Sue Crockford Gallery, 1994), unpaginated.
} 
artists' biographies when he blurs the truth in his own catalogues, as his anecdote about Ezra Pound demonstrates.

Pound's interrogation of biography and narrative references a Vasarian approach to art-historical research. Giorgio Vasari's desire to document the lives of artists in his 1550 treatise, The Lives of the Most Eminent Italian Architects, Painters, and Sculptors from Cimabue to Our Times, came from a desire to ensure that neither the artist's name, nor his fame, would ever be extinguished..$^{55}$ The Vasarian model of art history, however, does somewhat resemble a promotional system for Renaissance artists, particularly those from Florence. ${ }^{56}$ Vasari's 'ongoing project of monumentalizing and institutionalizing his aesthetic doctrines' was a means to establish his own taste as the paradigm of artistic practice. ${ }^{57}$ The histories written by Vasari demonstrate that 'artistic progress was articulated through metaphors of biological growth.' 58 The current art-historical inclination to create a grandiose biographical narrative continues Vasari's methodological tradition. Pound critiques this tradition in C.V.-a work in progress, when he essentially becomes his own art historian.

As discussed earlier, Krauss takes issue with the artist's identity being central to a work. She believes that, by 'discovering' who the artist is, we are fulfilling the 'goal of the narrative.' ${ }^{59}$ As art historians, we read artists' biographies as we do a 'detective story' and use them as a tool of examination where 'meaning reduces to just this question of identity. ${ }^{, 60}$ These diverse approaches to the biographical model demonstrate just how central the question of biography is to art history. Using biography as a methodological tool can be seductive for art historians. But, as artist

\footnotetext{
${ }^{55}$ Vasari, "Life of Leonardo Da Vinci, Florentine Painter and Sculptor, 1452-1519," 110.

${ }^{56}$ Donald Preziosi, The Art of Art History: A Critical Anthology, 2nd ed., Oxford History of Art (Oxford, UK: Oxford University Press, 2009), 15.

${ }^{57}$ Preziosi, 16.

${ }^{58}$ Preziosi, 14.

${ }^{59}$ Rosalind Krauss, "In the Name of Picasso," in The Originality of the Avant-Garde and Other Modernist Myths (Cambridge, MA: MIT Press, 1985), 28.

${ }^{60}$ Krauss, 28.
} 
Ian Burn explains, '[a]rt history should not be set apart from other kinds of history, nor should it be subservient to biographical, political or any other history.' ${ }^{61}$ Burn is of the view that conventional art history centres on the art historian and is, therefore, inherently autobiographical in its production: '[a]rt history is not monolithic.' ${ }^{62}$ He argues that '[a]rt history has always been far too important to be simply left up to art historians. ${ }^{93}$ Pound's survey show, The Great Exhibition, is an exhibition that questions the narrative of the artist biography. The notion of 'authorship,' which is central to our understanding of Pound and The Great Exhibition, also comes under pressure throughout. It is clear that the trope of the Author is employed readily by Pound, so that he can then systematically undermine it.

\section{Postmodern Ideologies of Authorship}

The incorporation of the work of other artists is an appropriate starting point from which to consider Patrick Pound's practice in relation to postmodernism. Artist Sherrie Levine asserts that her work functions alongside others to broaden the discussion about postmodern iteration:

I should make it clear that I don't think art should be any one thing - my work only has meaning in relationship to everyone else's project... I'm not trying to supplant anything; my work is in addition. The idea is to broaden the discussion, not to narrow it. ${ }^{64}$

This quote must have resonated with Pound, as it was cited in his 1994 exhibition catalogue for INTERNATIONAL: drawing on a reproduction at Te Manawa Art Gallery, Palmerston North. In that same interview, she also discusses the efficacy of reproductions: 'So much of our sense of art history is based on copies, fakes and

\footnotetext{
${ }^{61}$ Ian Burn, "Is Art History Any Use to Artists?" [1985] in Dialogue: Writings in Art History (Sydney, NSW: Allen \& Unwin, 2000), 6.

${ }^{62}$ Burn, 1.

${ }^{63}$ Burn, 14.

${ }^{64}$ Interview in Jeanne Siegel, ed., "After Sherrie Levine," in Art Talk: The Early 80s (Boston, MA: De Capo Press, 1988), 254. Included in Patrick Pound, "International," ed. Manawatu Art Gallery (Manawatu Art Gallery, 1994), unpaginated.
} 
forgeries. ${ }^{65}$ Pound echoes Levine when he observes: 'The fate of most "successful" art is to end up in a book by way of reproduction. Indeed, to end up in reproduction is the mark of success for an artwork.' ${ }^{66}$ It is, therefore, ironic that the four works in INTERNATIONAL all 'started their life as books. ${ }^{67} \mathrm{He}$ tore out the pages and drew on, erased and added to them until 'these art works on reproductions are themselves reproduced... returned to that labyrinth of reproductions, the endlessly inescapable library of art.' ${ }^{68}$ Pound saw the books as a 'ready-made or found object to be drawn on,' both literally and metaphorically. ${ }^{69}$

Both Levine and Pound's practices involve the dissemination and reproduction of other artists' artworks. For Levine, 'originality is a trope' and is interrogated through her practice. ${ }^{70}$ A notable example is her series, After Walker Evans, which includes After Walker Evans: 4 (Metropolitan Museum of Art: New York, NY), produced in 1981 [Fig. 8]. After Walker Evans: 4, a gelatin silver print produced by Levine, is a photograph of a reproduction of Walker Evans's iconic 1936 photograph, Alabama Tenant Farmer Wife (Metropolitan Museum of Art: New York, NY) [Fig. 9]. The intention of the photograph is to 'not be tyrannized by the original image' but, rather, to construct 'a relationship to the image.' ${ }^{71}$ The link between Levine's series After Walker Evans is important because it is an iteration of Evans's work, originally commissioned by Fortune magazine. Alabama Tenant Farmer Wife was published in Let Us Now Praise Famous Men alongside James Agee's text and discussed in the introduction to this thesis, and was also the subject of Pound's doctoral dissertation.

\footnotetext{
${ }^{65}$ Siegel, "After Sherrie Levine," 247.

${ }^{66}$ Patrick Pound, International. (Palmerston North, NZ: Manawatu Art Gallery, 1994), unpaginated.

${ }^{67}$ Ibid.

${ }^{68}$ Ibid.

${ }^{69}$ Ibid.

${ }^{70}$ Siegel, "After Sherrie Levine," 247.

${ }^{71}$ Siegel, 248.
} 
Pound distils what is at stake for artists like himself when he says of Levine's reproduced reproductions: 'We live at the end of the earth. I have only ever seen the work of Sherrie Levine in reproduction. ${ }^{72}$ Reproductions are the norm and INTERNATIONAL provides an example of Pound utilising this conceptual framework in his work. Where Walker Evans was emblematic of a particular paradigm, Levine has also come to occupy that space for artists such as Pound. As Daniel Palmer aptly puts it, 'postmodern photographic practice puts authorship under pressure. ${ }^{, 73}$ Geoffrey Batchen provides context to the discussion when he proclaims:

This is no doubt why the "illegal" collaborations staged by Sherrie Levine, in which she copied or simply reframed reproductions of the work of earlier photographers, struck such a chord in the 1980s, when themes of originality were much discussed; Levine seemed to be literally presenting her own creative work as nothing but a 'tissue of quotations,' in Barthes' famously prescriptive words. ${ }^{74}$

The appropriation of works authored by others is a strategy Pound uses to relentlessly place authorship under pressure. In INTERNATIONAL, Pound is literally drawing on reproductions of artworks pulled from books. Art historian Terry Smith argues, in 'The Provincialism Problem,' that geographical isolation from the centre is diminished through the availability of reproductions and copies. For artists like Pound, however, art history is distorted through the trickle-down of reproductions. ${ }^{75}$ Pound states that he chose reproductions of international artists just so he could 'send them to Manawatu' and because 'we were so removed from the action - the original - that we only ever saw it [the artwork] in its removed state, its reproduction; a copy. ${ }^{76}$

\footnotetext{
${ }^{72}$ Pound, International, unpaginated.

${ }^{73}$ Daniel Palmer, Photography and Collaboration: From Conceptual Art to Crowdsourcing (London, UK; New York, NY: Bloomsbury Academic, 2017), 38.

${ }^{74}$ Geoffrey Batchen, "Photography and Authorship - Still Searching - Fotomuseum Winterthur," July 10, 2012, http://www.fotomuseum.ch/en/explore/stillsearching/articles/26932_photography_and_authorship.

${ }^{75}$ Terry Smith, "The Provincialism Problem," Journal of Art Historiography, no. 4 (June 2011): 1.

${ }^{76}$ Pound, International, unpaginated.
} 


\section{A Selected History of Pound's 'Found' Works}

Patrick Pound's use of found and vernacular objects is symptomatic of his practice as a whole. From early works in the 1980s to The Great Exhibition, Pound has been demonstrating that collecting 'things,' and subsuming them into his own work is at the core of how he operates. While The Great Exhibition demonstrates the scope of Pound's photographic archive, there is a wider set of categories of objects that Pound collects.

In 1989, Pound began the collection Museum darts (1989-), which was, as the title suggests, a collection of folded paper darts found in museums. This collection series is included in The Great Exhibition in a larger display titled The collection shelves. Another early example of found objects used in Pound's practice is Fragments and Fakes (1989). In this work, Pound collects quotations and fragments of text and includes a 'Dictionary of Received Ideas' to echo Gustave Flaubert's own 'Dictionary of Received Ideas' (1880) in his novel Bouvard et Pécuchet. The exhibition UR1/International (1993) draws its name from a 'massproduced, framed photograph-mount which Pound includes as a sort of readymade art object, leaning up against the gallery wall in exactly the state in which it was purchased from a discount store. ${ }^{77}$ The use of readymades, whether photographs, text or objects, has always informed Pound's practice and can be seen throughout his work.

One work in particular, Summer Holiday 1962, made in 1986 (Ngā Taonga: Wellington), is a short film Pound produced following the death of his brother in the 1980s. Pound's Summer Holiday 1962 is named after the movie Summer Holiday (1963), which starred Cliff Richards, and the single that accompanied the movie. This earlier work of Pound's relies heavily on the use of vernacular photography from a family album - whether they are from his own family album or

\footnotetext{
${ }^{77}$ Ben Curnow, PATRICK POUND: URI INTERNATIONAL. (Wellington, NZ: Hamish McKay, 1993).
} 
a found album is unclear to us. The film starts with a distinctly steel guitarsounding riff joining the dulcet tones of Cliff Richards in the opening line: 'We're all going on a summer holiday.' The film transitions from one photograph to the next, cutting abruptly from a group of men standing in front of a house, to the same men in front of a lake and then next to the Craters of the Moon in Taupō. This sequence sets up the narrative of a group of men embarking on a summer holiday in New Zealand, just like the movie that is its namesake. As the song plays, the transition between shots becomes more rapid and the photographs show tightlycropped images of men in their underwear with close-up shots of their erections. Far removed from Cliff Richards' family-friendly jaunt, Pound's film chronicles a homoerotic summer holiday set in Taupō.

Summer Holiday 1962 transitions between tame and risqué photographs of the group of men. As Richards' voice begins to intensify, the transitions between shots also speed up; jumping from semi-naked men sunbathing with gay porn magazines covering their faces to tightly cropped photographs of erections and cutting to shaved poodles and subtropical palm trees. Pound's film parodies Richards' Summer Holiday: his inclusion of a photograph of some of the men posing outside a women's bathroom in front of a sign saying MISS TAUPO references the stowaway on Richards' bus who is a woman disguised as a man. It is important to understand the context of the time when Pound made the film: New Zealand was blanketed in a cloud of darkness from the HIV/AIDs crisis and consensual sex between gay men was still illegal as the Homosexual Law Reform Act was not passed until 1986. While the film appears to be comical and 'fun,' given this context there is a melancholic undertone. Summer Holiday 1962 is one of the earlier instances of Pound using found vernacular photography in his work. His filmic use of found photographs, however, is not seen again unless we include his contemporary site-specific installations, Drive by (en passant) [Fig. 10] and The Cliff House [Fig. 11] in The Great Exhibition. 
Pound's oil painting on books, No (2005, Hamish McKay: Wellington) is yet another example of how Pound uses found objects [Fig. 12]. In this diptych, one larger white painting positioned to the left is pierced by two black angular painted shapes emerging from the upper and lower edges. Accompanying it is a much smaller painting in tones of burnt umber, with the corners painted black; an oval shape is painted in the middle of the painting. Stepping back, the paintings appear to read as 'No,' but upon closer inspection their original form as books is evident. Shown in the exhibition before and after at Hamish McKay (1-24 April 2009), the work demonstrates another of the ways that Pound integrates found objects into his work. In his roundabout way, Pound describes the material he uses as 'redundant... I'm just putting them back to use for myself and other people ... It's really just a big up-cycling project. ${ }^{978}$ Nevertheless, the satirical nature of this painting is nothing new, demonstrating an important process evident in his practice.

Pound is an artist who is informed by art history and we can see this in works such as Flinders Notebook (2007, Hamish McKay: Wellington), in which Pound has used a 'found' oil painting from a second-hand shop and added elements of his own [Fig. 13]. The amateur painting of an Australian landscape was discarded at some point but has been purchased by Pound and integrated into his own work. Pound's intervention comes in the form of a subtraction as he has redacted some of the information in the painting by adding a black rectangle hovering in the centre. $\mathrm{He}$ has signed his name, 'Pound,' in the bottom right-hand corner. This practice of finding discarded objects and utilising them in art is not new and, of course, Duchamp's conceptualisation of the readymade again comes to mind. Robert Rauschenberg's Erased de Kooning Drawing (1953, San Francisco: SFMoMA) [Fig. 14] is another important example of this practice, where Rauschenberg erased a Willem de Kooning work and then presented it as 'an extended notion of the artist as creator of ideas. ${ }^{, 79}$ On the other hand, Pound's work could conceivably be a homage to Kazimir Malevich's Black Square (1915: Moscow, Tretyakov Gallery)

\footnotetext{
${ }^{78}$ Dan Rule, "Lost \& Found," Art Collector, 2013, 127.

${ }^{79}$ Sarah Roberts, "Erased de Kooning Drawing," SFMOMA, 2013, https://www.sfmoma.org/artwork/98.298/essay/erased-de-kooning-drawing/.
} 
[Fig. 15], which is hailed as heralding abstraction in the twentieth century. Ironically, Black Square is now known to be a racist 'joke' referencing the 1897 comic work by French satirist Alphonse Allais 'Negroes Fighting in a Cellar at Night. ${ }^{, 80}$ Malevich's Black Square could be considered within that same history of postmodern citation that Pound also inhabits.

Ian Burn vehemently argues that '[a] sense of art history is part of the critical basis on which artists construct 'a future' of art. ${ }^{81}$ It is here where we can consider Burn's own oil painting, 'Value added' landscape no. 11 (1993, AGNSW: Sydney) as providing art-historical context for Pound's Flinders Notebook [Fig. 16]. Burn's work is an amateur landscape painting found in a second-hand shop, which has been incorporated into his own work. The painting is veiled with a layer of perspex screen-printed with text and affixed onto the surface of the painting. The text describes the painting while simultaneously addressing the viewer and, according to Burn, 'reflects on itself as text' ${ }^{82}$ The work is a condensation of 'Burn's thinking on the tradition of Australian landscape painting, representation, language, artmaking and its reception.' ${ }^{83}$ Ian Burn speaks of art as a 'collective enterprise,' which is contributed to from numerous sources, including the past, present and future. ${ }^{84}$

Pound has been amassing a collection of objects including books, quotes and photographs for decades. As he explains:

Like most artists, I started collecting to inform my work. What seems to have happened is that gradually the collections became the work. Before I started

\footnotetext{
${ }^{80}$ Carey Dunne, "Art Historians Find Racist Joke Hidden Under Malevich's 'Black Square,"” Hyperallergic, November 13, 2015, https://hyperallergic.com/253361/art-historian-findsracist-joke-hidden-under-malevichs-black-square/.

${ }^{81}$ Burn, "Is Art History Any Use to Artists?," 14.

${ }^{82}$ Art Gallery of New South Wales, "'Value Added' Landscape No. 11," accessed February 24, 2018, https://www.artgallery.nsw.gov.au/collection/works/75.2003/.

${ }^{83}$ Art Gallery of New South Wales.

${ }^{84}$ Burn, "Is Art History Any Use to Artists?," 9.
} 
seriously collecting things, I collected other people's photographs and sorted them into categories. ${ }^{85}$

The use of found objects has long been integral to Pound's practice and draws on an extensive history of artists authoring found objects - from Duchamp and Robert Rauschenberg to Australian artists like Ian Burn. Pound's integration of over 4,000 vernacular photographs and more than 300 items from the NGV's collection in The Great Exhibition is the culmination of Pound's extensive and considered use of found material.

\section{Photography and its Authors}

Any discussion about Pound's use of vernacular photography brings to the fore the complex relationship between authorship and photography. Photography might be considered a collaborative process, involving numerous authors who are all involved in the various stages of production a photograph goes through. It is also evident that photography's tenuous relationship to the Author is situated in its very foundations. The story of the inception of photography is not a linear narrative. Photography was the result of several decades of experimentation in 'protophotography' by numerous people. ${ }^{86}$ It is estimated that from the late eighteenth century until the 'arrival' of photography in 1839 , there were between 21 and 24 practitioners who claimed 'a desire to photograph. ${ }^{87}$ Batchen argues that this shared aspiration to photograph 'was a product of Western culture rather than some isolated individual genius. ${ }^{88}$

The development of photographic technologies came about through extensive experimentation that built on prior successes and failures. The outcome of some

\footnotetext{
${ }^{85}$ Patrick Pound, "The Gallery of Air," National Gallery of Victoria, 2014, https://www.ngv.vic.gov.au/essay/the-gallery-of-air/.

${ }^{86}$ Geoffrey Batchen, Each Wild Idea: Writing, Photography, History (Boston, MA: MIT Press, 2000), 6.

${ }^{87}$ Batchen, Each Wild Idea, 5-6.

${ }^{88}$ Geoffrey Batchen, Burning with Desire: The Conception of Photography (Cambridge, MA: MIT Press, 1997), 52.
} 
early experiments with silver nitrate and light was published in June 1802 by Thomas Wedgwood and Humphry Davy in the Journals of the Royal Institution of Great Britain. ${ }^{89}$ Nicéphore Niépce's work with heliography from 1826 to 1827 produced View from the Window at Le Gras (Harry Ransom Center, Texas). Throughout 1827 and 1828, Louis Daguerre was in correspondence with Niépce, expressing his aspiration to fix images of nature: 'I cannot hide the fact that I am burning with desire to see your experimentations from nature. ${ }^{90}$

It was at the French Academy of Sciences, on 7 January 1839, that an official announcement was made that Daguerre had invented photography with his 'Daguerreotype.' ${ }^{91}$ A few weeks after this announcement, the Royal Society in London reactively announced William Henry Fox-Talbot's 'photogenic drawing' in a paper titled The Art of Photogenic Drawing. ${ }^{92}$ This was a 'significantly different' photographic process to that of Daguerre's. ${ }^{93}$ As Batchen notes: 'After undergoing a few refinements, Talbot's paper-based image and negative-positive method proved even more amenable than the daguerreotype to a wide variety of uses and provided the basic principles of the photography we still use today. ${ }^{94}$ If we consider the very conception of photography as collaborative and also note the widespread interest at the time of photography's invention - we can begin to position Pound's practice of collecting photography as fulfilling a deep-seated fascination for the medium and locate it as a collaborative process.

Photography can also be seen as a collaboration with nature. For Daguerre, ' $[\mathrm{t}] \mathrm{he}$ Daguerreotype is not merely an instrument which serves to draw Nature; on the contrary it is a chemical and physical process which gives her the power to

\footnotetext{
${ }^{89}$ Batchen, Burning with Desire, 26.

${ }^{90}$ Batchen, Each Wild Idea, 6.

${ }^{91}$ Batchen, Each Wild Idea, 3.

${ }^{92}$ William Henry Fox Talbot, Some Account Of The Art Of Photogenic Drawing, Or The Process By Which Natural Objects May Be Made To Delineate Themselves Without The Aid Of The Artist's Pencil (London, UK: R. \& J. E. Taylor, Red Lion Court, 1839).

${ }^{93}$ Batchen, Each Wild Idea, 3-4.

${ }^{94}$ Batchen, 4.
} 
reproduce herself.' ${ }^{95}$ Similarly, Talbot ascribes 'nature' as 'both the artist and that artist's object of study,' stating that 'natural objects may be able to delineate themselves without the aid of the artist's pencil.' ${ }^{96}$ Even through the early stages of development, both Daguerre and Talbot recognised the inherent collaboration with nature as part of the process of making a photograph.

To further consider the collaborative nature of photography, we must also examine how photographs are produced. For example, if we consider a single photograph, we could ascribe the role of 'author' to the person who takes the photograph, the person who develops the film, or the person who developed the photograph from the negative. In some cases, significant retouching or spotting on photographic negatives and prints is part of the process. Perhaps we may even consider the camera as an authorial agent. Geoffrey Batchen argues that ' $[t]$ he authorship of individual photographs is therefore often a collective enterprise stretched over a considerable time period.' According to Batchen, when scholars or museums ultimately attribute all this to a single author or studio, it 'allows them to avoid having to address the complexity of authorship in all its various manifestations. ${ }^{97}$ As theorist Marshall McLuhan notes: 'nobody can commit photography alone.' 98 If we extend these ideas to Pound's practice or even to the confines of The Great Exhibition alone, how can we consider the authorship of the roughly 4,000 vernacular photographs on display? While quantifying the number of authors could be considered as reductive, it is a useful mechanism to consider the collaborative process within which Pound's practice operates.

Daniel Palmer charts a range of alternative ideologies surrounding the notion of authorship and photography. Palmer argues that the model of a 'single author' helped 'fuel' the art market, with major museums playing an 'important role in

\footnotetext{
${ }^{95}$ Batchen, 11-12.

${ }^{96}$ Batchen, 11.

${ }^{97}$ Batchen, "Photography and Authorship - Still Searching - Fotomuseum Winterthur."

${ }^{98}$ Cited in Palmer, Photography and Collaboration, 1.
} 
reaffirming these histories. ${ }^{99}$ Palmer writes that the 'artificial stabilisation of single authors' has led to a 'neglect of collaborative labour in the history of photography.' ${ }^{100}$ According to Palmer, the reason for this omission 'is bound up with the construction of the modern author' and the subsequent 'anxieties around originality and intentionality. ${ }^{, 101}$ Batchen similarly describes how, when considering vernacular photography, 'traditional art historical categories such as originality, authorship, intention, chronology, and style seem completely inadequate to this kind of material.' 102

A Marxist perspective is echoed by Griselda Pollock, who notes that the construction of the singular author performs an 'economic function. ${ }^{103}$ The financial return of art is based on 'the status of its author' and, so, relies on the construction of a narrative that enhances the author's status and will thereby 'stabilise prices' of their art as a commodity. ${ }^{104}$ Batchen points to the 1970 s when photography, somewhat anachronistically, found a place in the art world as 'the art market sought to revitalize itself by promoting the sale and collection of both historic and contemporary photography. ${ }^{105}$ Carol Squiers positions photography as a cheaper and more accessible alternative to collecting painting. ${ }^{106}$ However, Squiers is explicitly referencing 'art photography,' not the thousands of snapshots for sale in second-hand stores or on eBay. The snapshots on eBay that Pound collects are 'cheap' because they lack an author or a status in the process of production that I have elucidated.

Walter Benjamin famously summarised the implications of the reproducibility of photography in his essay 'The Work of Art in the Age of Mechanical

\footnotetext{
${ }^{99}$ Palmer, 20.

${ }^{100}$ Palmer, 35.

${ }^{101}$ Palmer, 19.

102 Batchen, Each Wild Idea, 77.

${ }^{103}$ Pollock, "Artists Mythologies and Media Genius, Madness and Art History,” 63.

${ }^{104}$ Ibid.

${ }^{105}$ Batchen, Each Wild Idea, 4.

${ }^{106}$ Carol Squiers, ed., Over Exposed: Essays on Contemporary Photography (New York, NY: The New Press, 1999), 3.
} 
Reproduction,' originally published in 1935 . His oft-repeated adage is: '[t]hat which withers in the age of mechanical reproduction is the aura of the work of art. ${ }^{107}$ For Benjamin, the aura is about the association of 'time' and 'space' with what he terms 'the authentic.' 108 Through mechanical reproduction, the 'presence of time and space' is made absent. ${ }^{109}$ A work of art 'designed for reproducibility, for example, 'a photographic negative ... can make any number of prints; to ask for the "authentic" prints makes no sense. ${ }^{110}$ According to Susan Sontag: 'The traditional fine arts rely on the distinction between authentic and fake, between original and copy, between good taste and bad taste.' ${ }^{111}$ For photography, these distinctions are blurred.

Photography is a medium that lends itself to multiple authors and reproduction, creating a headache for the art market: 'Unease about photography's democratic promise has, particularly in the hands of art historians, been overcompensated for in the figure of the bloated author.' ${ }^{112}$ Carol Squiers suggests that:

One result of this totalizing desire to see the entire medium as a singular ontogeny was that a small group of photo historians, photo dealers, and curators created a discourse about photography based mainly on the look of the images - and, with few exceptions, largely marginalized the popular, social, commercial, and political uses and meanings of photography. ${ }^{113}$

What Squiers highlights here is that the legitimation of photography in the art market 'alongside the other fine arts,' was at the expense of other photographies. ${ }^{114}$ Those that do not conform and thereby evade 'traditional art historical categories such as originality, authorship, intention...' remain hard to categorise and

\footnotetext{
${ }^{107}$ Cited in David B. Goldblatt, Stephanie Patridge, and Lee B. Brown, eds., Aesthetics: A Reader in Philosophy of the Arts, 4th ed. (New York, NY: London, UK: Taylor and Francis, 2018), 67.

${ }^{108}$ Ibid.

${ }^{109}$ Ibid

${ }^{110}$ Ibid.

${ }^{111}$ Sontag, On Photography, 149.

${ }^{112}$ Cited in Palmer, Photography and Collaboration, 19.

${ }^{113}$ Squiers, Over Exposed, 3.

${ }^{114}$ Squiers, 2.
} 
subsequently shut out of the art market and, consequently, art-historical discourse. ${ }^{115}$ As Batchen reiterates:

Although historical accounts of photography written in the nineteenth or early twentieth century tend to include an eclectic selection of photographies, throughout the late twentieth century, most histories tenaciously focused on the artistic ambitions of the medium, excluding all other genres except as they complement a formalist art-historical narrative. ${ }^{116}$

Pound's practice is of note here as The Great Exhibition is premised on the inclusion of these photographies - of precisely the marginal, popular, social and commercial photographs identified by Squiers. It is a show featuring thousands of photographs, none of which has been taken by Pound. Rather than museums or art dealers arbitrating taste and dictating the inclusion of singular artists, it is Pound, who uses eBay and online auctions to buy photographs with generally unknown authors, shaky provenance and mostly anonymous subjects. We can locate Pound's practice in a space that both interrogates the automatic positioning of the singular artistic voice through the integration of 'authorless' photographies, while simultaneously engaging in that very practice of authenticating himself as the author by staging his retrospective at a major institution like the NGV.

When Ian Burn asks '[h]ow do you turn art history into an exhibition?' - I propose that the answer is The Great Exhibition. ${ }^{117}$ Pound has continuously engaged with issues surrounding the narrative of the Author and, through his practice, disrupted this trope. A narrative about the nature of art history is constructed by Pound using mythologies, parody, conceptualism, curation and exhibition. Within art history, as a discipline, there is an inclination to imagine the 'truth' of the artist as a means to explain their work, as Barthes emphasises in 'The Death of the Author.' Pound uses this to his advantage. The destabilisation in The Great Exhibition of 'great' works of art, like those from the NGV's collection, in order to express his own ideas about absence, and under his own name, is somewhat audacious. Pound's works reflect a

\footnotetext{
${ }^{115}$ Batchen, Each Wild Idea, 77.

${ }^{116}$ Batchen, 57.

${ }^{117}$ Burn, "Is Art History Any Use to Artists?," 11.
} 
postmodern moment where originality is no longer recognisable; the ironic iterations are merely an extended 'Dad joke.' To destroy those fictions would be to tear down the whole illusion.

\section{Burn's Art History}

Ian Burn's essay 'Is art history any use to artists?' (1985) is useful to guide the discussion of issues of authorship, biography and art history. Despite being written in the 1980s, Burn's analysis of John Brack's The car (1955: NGV) [Fig. 17] is useful as a pivot for a discussion about the shifting narratives of artworks when they are displayed in different institutional contexts. Burn's meditation, which shifts between The car and autobiography, provides a useful lens to apply to the study of Patrick Pound. It is also pertinent because the painting is one of the works from the NGV's collection included in The Great Exhibition and hangs within his site-specific installation Drive by (en passant) (2016-2017) [Fig. 10].

In his 1985 essay, Burn uses The car to discuss the function and fallacies of art history. For Burn, The car is a painting imbued with institutional baggage - its meaning transforming with the ebb and flow of art-historical trends. Successive reinterpretations of The car have augmented, or supplemented, its meaning over time. A contemporary example is the exhibition Australia (21 September - 8 December 2013), staged at the Royal Academy of Arts in London, where The car was presented as a representation of Australian modernity. ${ }^{118}$ While this may seem unsurprising, given John Brack was indeed a painter concerned with the modernist aesthetics of Australian art in the 1950s, it demonstrates how a nationalist narrative can be constructed, and the reading of a painting transformed, based on the institutional setting it is placed within.

\footnotetext{
${ }^{118}$ Nick Miller, "London Awaits Australia, the Exhibition," The Age, May 3, 2013, http://www.theage.com.au/entertainment/london-awaits-australia-the-exhibition-201305032iwzp.html.
} 
John Brack's The car, then, operates to communicate a wider discussion about the historical, social and institutional contexts a painting is displayed within. Each space that The car is displayed within presents us with a new context within which to consider its display. Although the painting remains the same, The car presents us with an opportunity to discuss the contextual transformation of objects and the multiplicity of meanings that Pound is consistently engaging with throughout his practice. The inclusion of The car in The Great Exhibition was a conscious choice by Pound, to interrogate the painting's interpretation through the use of his own collection of vernacular snapshots. Functioning in this thesis as a signifier, The car weaves together ideas about interpretation, authorship, biography and parody in relation to art and art history.

The professionalisation of art history has, in the eyes of Burn, resulted in art historians neglecting to look at art. ${ }^{119}$ Burn postulates that art historians have shown 'a reluctance to involve themselves in uncovering and exploring the historical sensibility embodied in works of art. ${ }^{120}$ Instead, there is a tendency for art history to be about 'what artists wrote or said rather than about what they made and did.' ${ }^{121}$ This is emblematic in van Gogh's own la vie romancée, which has contributed a linear narrative to the artist, as opposed to a history based on the work he produced.

Burn intends the viewer to look closely at The car and so too does Pound when he includes it in The Great Exhibition. The car depicts four figures, almost certainly a family, inside a car driving through a rural landscape. The painting is framed so it looks as though we, the viewer, are glancing over to our right, observing the car passing as if it were a snapshot. The occupants of the car look over at us; the woman smiles, and the two children look out from the back seat. The man stares ahead, unflustered by the distraction, as he continues to concentrate on driving his

\footnotetext{
${ }^{119}$ Geoffrey Batchen, "Introduction: Pictography: The Art History of Ian Burn," [1991] in Dialogue: Writings in Art History, by Ian Burn (Sydney, NSW: Allen \& Unwin Pty Ltd, 2000), xi-xix.

${ }^{120}$ Burn, "Is Art History Any Use to Artists?," 4.

${ }^{121}$ Geoffrey Batchen, "Introduction: Pictography: The Art History of Ian Burn," xi.
} 
Triumph Mayflower, a characteristically British car, through the Australian countryside. The oil paint has been flatly applied to create a sense of twodimensionality. The almost monochromatic palette delivers a mix of browns, reds, and beige, while a muted green background has been employed to signify the rural landscape. The family are split by the middle pillar of the Triumph Mayflower, creating a mirrored symmetry within the painting. Hung at eye level in The Great Exhibition, the occupants within The car are looking at us as we mirror them, passing them by and looking back.

Why does The car by Brack matter? Burn argues that, as art historians, we interpret the painting to fit our own models of institutional art history: '[a]rt history likes to categorise, to neatly package artists, periods and tendencies, and to individualise, isolating particular artists from friends, colleagues and even mentors.' ${ }^{122}$ The latter part of this statement is pertinent to Burn, as John Brack was his teacher at the National Gallery School in Melbourne, making his discussion about The car an autobiographical one. The collegial relationship between Burn and Brack is representative of a 'Melbournian tradition of art making.' ${ }^{123}$ By including The car in The Great Exhibition at the NGV in Melbourne Pound is, therefore, building on this tradition and drawing attention to himself as a Melbourne-based artist. To further emphasise these relationships, Pound has included an art work by Burn in The Great Exhibition - Three Mirror/Structure (1969, NGV: Melbourne). The interconnectedness of Melbourne histories continues as I, too, add to it as a student under the guidance of Geoffrey Batchen, who was mentored by Ian Burn and contributed to his book, Dialogue: Writings in Art History (1991).

For Burn, '[i]rony, even parody, plays a crucial role in both affirming and unmasking the contradictory structures inherent in Australian culture.' ${ }^{924}$ The former director of the NGV, Patrick McCaughey, noted that Brack was a 'genuinely

\footnotetext{
${ }^{122}$ Burn, "Is Art History Any Use to Artists?," 8.

${ }^{123}$ Batchen, "Introduction: Pictography: The Art History of Ian Burn," xv.

${ }^{124}$ Burn, "Is Art History Any Use to Artists?," 6.
} 
complex artist, even if he may look direct, accessible and easy to read. ${ }^{125}$ For Burn, it is ironic that The car is categorised as a quintessentially 'Australian' painting when, as he highlights, the car Brack paints is a British import, not the archetypal Holden that patriotic Australians may identify with. He points out that, given the popularity of the car in the 'geography of Australian life, surprisingly few cars are represented in its art. ${ }^{126}$ This absence is conspicuous for Burn, given that domestic cars were increasingly accessible to the middle classes in the 1950s when Brack painted this iconic Australian work.

Burn argues that 'a story without any factual basis may serve to reveal greater "cultural truths" than any other account. ${ }^{127}$ Pound's fabricated narratives pervade his biography and provide us with an insight into the construction of art-historical narratives in general. An example of this is the addition of Ezra Pound into Patrick Pound's narrative within the exhibition catalogue. This practice was also employed by Burn, who recalls an anecdote about the French artist Fernand Léger visiting the Australian countryside in 1956 and concludes that Léger was only able to translate the 'logic' of the landscape after viewing paintings by Australian artists like Sidney Nolan. ${ }^{128}$ The implication here is that Léger was able to understand the inherent 'Australian-ness' of the landscape just by looking at Australian paintings. Burn writes, however, that ' $[\mathrm{a}] \mathrm{n}$ anecdote creates its own necessity, truth notwithstanding' noting that anecdotal evidence operates to confirm a nationalist narrative here. ${ }^{129}$ Léger died in 1955, so Burn's report of his visit to Australia in 1956 was a fiction: it was Nolan who visited Europe in the 1950s and learned from Léger's paintings. ${ }^{130}$ It is a strategy of art history to identify the signifiers of place and these function in much the same way as biography. They are used to explain a

\footnotetext{
${ }^{125}$ Patrick McCaughey, "The Complexity of John Brack," in John Brack: A Retrospective Exhibition, by Robert Lindsay (Melbourne, VIC: National Gallery of Victoria, 1987), 7.

${ }^{126}$ Burn, "Is Art History Any Use to Artists?," 5.

${ }^{127}$ Burn, 3.

${ }^{128}$ Burn, 4.

${ }^{129}$ Burn, 3.

${ }^{130}$ Ian Burn, "Sidney Nolan: Landscape and Modern Life," in Radical Revisionism: An Anthology of Writings on Australian Art, ed. Rex Butler (Brisbane, QLD: Institute of Modern Art Publishing, 2005), 213.
} 
work through the ability of the art historian to situate a work within a certain context, like 'Australian painting.'

Ironically, Brack had initially composed The car within a suburban street. But 'the paraphernalia of the street... robbed the faces of dramatic emphasis,' whereas 'the country landscape solved this problem. ${ }^{131}$ The switch to a rural setting for The car was a means to emphasise the social phenomenon of families driving from the city on a Sunday to experience the country. ${ }^{132}$ The car, according to Burn, 'fulfils a quite particular psychological need in this society, linking family and landscape. ${ }^{133}$ He notes that a car 'which gives you access to the countryside also isolates you from the outside world. ${ }^{134}$ McCaughey also comments that, "where the representative nuclear family smiles its way through a bleak Australian landscape, the ironic manner is a way of coping with absurdity. ${ }^{\text {135 }}$ The conscious use of social irony in Brack's paintings is clearly not lost on Pound. ${ }^{136}$

Anecdote, parody and irony are all employed in Pound's work. His inclusion of The car, from the NGV's permanent collection, in The Great Exhibition engages with a history of art-making and criticism in Melbourne, which is emphasised by the ironic style in which The car is presented. ${ }^{137}$ Hung on the off-white walls in the sixth gallery, The car is displayed above a long line of photographs, mostly depicting the same subject - mirroring the tightly cropped views of people in cars [Fig.18]. The cars all face the same direction, with their passengers' faces also looking out, as though Pound is proving the universalism of the scene that Brack

\footnotetext{
${ }^{131}$ John Brack cited in Sasha Grishin, The Art of John Brack, vol. 1 (Melbourne, VIC: Oxford University Press, 1990), 51.

${ }^{132}$ Brack cited in Grishin, 51.

${ }^{133}$ Burn, "Is Art History Any Use to Artists?," 7.

${ }^{134}$ Ibid.

${ }^{135}$ McCaughey, "The Complexity of John Brack," 7.

${ }^{136}$ John Brack describes his style of paintings as "social irony' in Chris McAuliffe, "John Brack: The Forgotten People," in Radical Revisionism: An Anthology of Writings on Australian Art, ed. Rex Butler (Brisbane, QLD: Institute of Modern Art Publishing, 2005), 233.

${ }^{137}$ Geoffrey Batchen, "Introduction: Pictography: The Art History of Ian Burn," xv.
} 
has painted, while simultaneously disproving the 'Australian-ness' of the painting. As we ask ourselves - is this curation or collage? - the only certainty here is that we are in on Pound's joke. His sense of irony offers a parody of Australian art history - a blague du jour, Pound's own 'joke of the day. ${ }^{\text {'138 }}$

Lining the wall parallel to The car, a hundred or so photographs in the site-specific installation Drive by (en passant) shows people beside Brack's painting. The first photograph is consumed by a crooked horizon, the foreground blemished with dry fissures. Out of frame, the bonnet of a car emerges, as if it is the first photograph in an Eadweard Muybridge-style Car in Motion installation on the walls of the NGV. In the next photograph, a similar horizon dominates the frame - only this view shows the body of the car, although the back is cut off by the framing. The third picture is a tightly cropped photograph of a woman driving. The series continues, wrapping around the gallery wall, with photographs of dogs driving, press photos and movie stills. The site-specific installation is reminiscent of a scene in $F$ for Fake, in which Oja Kodor walks around in order to attract the attention of onlookers. The film cuts to men leaning out their car windows, gazing at her and framed like the photographs in Pound's display of vernacular photographs. The procession of men is each framed by their car window. The film cuts back and forth to a small screen showing these men turning their gaze around to look outside of the frame [Fig. 19]. It is here that we stop to ask ourselves what they are looking at.

On the other side of the gallery, at the end of the line of photographs, Pound has included four crayon sketches by John Brack, which are all titled (Study for The car) (all c. 1955: NGV), and hung parallel to the snapshots [Fig. 20]. Pound is asking us to make a connection between the four iterations of (Study for The car) on one side of the gallery and the painting of The car on the other. The crayon sketches serve as a reminder of the development process for the scene that Pound has created. It begins and ends with The car, with the space in between filled with

\footnotetext{
${ }^{138}$ Burn references Manet's ability to expose the inappropriate themes of Classical art through an acute sense of irony, or 'blague' translating to 'joke,' as cited from Burn, "Is Art History Any Use to Artists," 11.
} 
his own collection of vernacular photographs. The car provokes us to closely examine Pound's collecting taxonomies and his modes of display. The integration of The car into The Great Exhibition symbolises the effort Pound has taken to displace the narrative of the 'great' 'Australian' painting by Brack. He achieves this by situating the painting within his own installation, Drive by (en passant), implicating the painting in his own narrative. The car is a central point of connection between the NGV's collection and the vernacular photographs it intersects with [Fig. 10]. This trope is repeated throughout Pound's survey show as a mechanism to connect his own vernacular works to a wider art-historical discourse.

\section{The Instability of Meanings}

The purpose of this thesis is to interrogate the art-historical production and transformation of meaning that Pound presents us. As he writes, 'My work treats the world as a puzzle. It seems to say: if only we could find all the pieces we might solve the puzzle.' ${ }^{139}$ This statement echoes a central tenet of Barthes' argument that "when the Author has been found, the text is "explained." ${ }^{140}$ It suggests that, rather than 'deciphering' a work, we should aim to 'disentangle' it. ${ }^{141}$ In Pound's work, there is no 'secret' or 'ultimate meaning' - the works transform based on the context in which they are read and by whom they are read. ${ }^{142}$ The instability of the layout and execution of Pound's works adds weight to this argument. For example, the staging of one of Pound's series, The big sleep (2007-2017), alters each time it is shown. The series incorporates newly acquired photographs and the layout is altered to fit the space in which the work is being shown. Photographs are subtracted when they have become surplus to Pound's intentions. This work illustrates the complexities of attempting to locate the correct reading, particularly

\footnotetext{
${ }^{139}$ Maggie Finch, The Great Exhibition, ed. Mark Gomes (Melbourne, VIC: National Gallery of Victoria, 2017), 146.

${ }^{140}$ Barthes, "The Death of the Author," 147.

${ }^{141}$ Ibid.

${ }^{142}$ Ibid.
} 
when texts are transformed and meanings are mutable. This idea is at the heart of my argument.

Susan Sontag's pivotal work On Photography (1977) has substantially informed my meditation on The Great Exhibition. The discussions instigated in this text have proved influential. It is my contention that Sontag has been a major influence for Pound's practice, as she pre-empts some of the strategies with which Pound engages. Firstly, Sontag discusses in depth the link between surrealism and the appropriation of found objects and photography:

... it was Breton and other Surrealists who invented the secondhand store as a temple of vanguard taste and upgraded visits to flea markets into a mode of aesthetic pilgrimage. The Surrealist ragpicker's acuity was directed to finding beautiful what other people found ugly or without interest and relevance - bric-abrac, naïve or pop objects, urban debris [...] For photographs themselves satisfy many of the criteria for Surrealist approbation, being ubiquitous, cheap, unprepossessing objects. ${ }^{143}$

Sontag observes that the surrealist strategy of using found objects in artworks began as a 'radical criticism of modern culture' but has culminated in 'an accumulation of oddities' or 'a joke.' ${ }^{144}$ When we consider Pound's practice, it becomes difficult to single out any particular example of his ironic temperament because he aims wholly and fully to 'put the dad joke in conceptual art.' ${ }^{145}$ One of the display cases in The Great Exhibition is most memorable to me for the ironic assemblage of objects within, which includes an instantly-recognisable Donald Trump mask made of silicon [Fig. 21]. Adjacent to the pumpkin-coloured mask are other found objects that are part of Pound's collection. Amongst these is Robert Musil's book, The Man Without Qualities (1930-43), which casts an 'ironic hue' over the assemblage with its questions regarding the morality and ethics of Austrian society during the descent into Nazism in the 1930s. ${ }^{146}$ While the irony of Trump's links to Nazism

\footnotetext{
${ }^{143}$ Sontag, On Photography, 78-79.

${ }^{144}$ Sontag, On Photography, 75.

${ }^{145}$ Pound, The Space Museum Guide / Collected Works: Telling Things, 10.

${ }^{146}$ Thomas Harrison, "The Essayistic Novel and Mode of Life: Robert Musil's The Man without Qualities," Republics of Letters 4, no. 1 (October 2014): 11.
} 
will not be lost on contemporary audiences, Pound goes further by placing a box of PrepKit C, an 'electrolyte gastrointestinal lavage preparation' solution, behind the mask of Trump. ${ }^{147}$ The glass shelf above houses a collection item from the NGV titled Rat and snake (1810-60), with its label conspicuously hovering above Trump's head. Pound was installing The Great Exhibition in the weeks leading up to its opening on 31 March 2017 while, simultaneously, xenophobic fascist sentiments were rising in the United States of America under the Trump administration after Executive Order 13780, 'Protecting the Nation from Foreign Terrorist Entry into the United States,' was enacted. By drawing text and objects together, Pound has provided a truly ironic, surrealist assemblage of found objects that audiences would have related to at the time of the exhibition.

It is the shifting of meanings that Pound deliberately probes throughout The Great Exhibition. He dares us to draw a direct comparison between the Trump mask, The Man Without Qualities, PrepKit C and Rat and snake. The assemblage functions as an ironic statement, but to what end? The cabinet is located in the largest of the gallery spaces in the exhibition, which contains most of the works from the NGV collection. It is also the location of the site-specific installation The Museum of there / Not there (2017), in which '[a]ll of the things in this room are asked to stand in for an absence. To make its presence shimmer. ${ }^{, 148}$ Absence, then, is the central tenet of this installation. Standing in the gallery, you hear a recording of The Zombies' song She's Not There (1965: Decca Studios); you see the 'Hillary for President 2008' badge on the shelf above Trump mask; and turn around to see a life-size cut-out of Hillary Clinton, grinning back [Fig. 22]. Individually, these objects each have an understood meaning but situated together in The Great Exhibition their meanings change: ' ... things have little to do with each other until they come into contact.' ${ }^{149}$ The power of this assemblage lies in how these pieces are read, as Barthes would agree.

\footnotetext{
${ }^{147}$ Medsafe, "Product Information," Medsafe, 2015, http://www.medsafe.govt.nz/profs/Datasheet/p/PrepkitCsol.pdf.

${ }^{148}$ Finch, "The Great Exhibition Artwork Labels," 54.

${ }^{149}$ Finch, The Great Exhibition, 136.
} 
Roland Barthes talks about 'refusing to assign a "secret" and ultimate meaning' to text, a refusal which, in turn, liberates it. ${ }^{150}$ Susan Sontag echoes this sentiment in relation to the photographic image: '[a]ny photograph has multiple meanings.,'151 She emphasises that the context in which photographs are shown can suggest an alternative meaning but 'none can secure' it. ${ }^{152}$ Sontag's argument is important to consider here because The Great Exhibition, as an installation, relies on the dislocation of context of the thousands of vernacular snapshots it presents. It is Pound who has assigned his own context within which to 'read' them.

Pound's practice can be described as interrogating the relationship between photography and the author, as is evident in The Great Exhibition. By using vernacular photography, found objects and appropriating the NGV's collection under the title Patrick Pound: The Great Exhibition, Pound destabilises previously understood meanings. According to Finch, '... he hopes to give the works he has selected a temporary 'sabbatical' from their agreed meanings, and is encouraging the audience to also rethink them. ${ }^{153}$ This was evident throughout The Great Exhibition, when I watched visitors make their own translations of Pound's vernacular photographs and use of collection works.

Exemplifying Pound's notion of taking a temporary sabbatical from usual meanings and reconstructing narrative is his use of David Moore's Migrants arriving in Sydney (1966: NGV) in The Museum of There / Not there (2017) [Fig. 23]. The photograph, shot on colour film but printed as a gelatin silver print, sits within the collective Australian memory as a representation of immigrants arriving in Australia. It featured in the exhibition The Photograph and Australia and now is included in The Great Exhibition. The NGV describes Moore's Migrants arriving in Sydney as 'capturing the hopes and fears of people spanning several generations'

\footnotetext{
${ }^{150}$ Barthes, "The Death of the Author," 147.

${ }^{151}$ Sontag, On Photography, 23.

${ }^{152}$ Sontag, 106.

${ }^{153}$ Finch, "The Great Exhibition Artwork Labels," 18.
} 
after 'coming to the end of a long sea-voyage.' ${ }^{154}$ The AGNSW website, however, states that the image is a 'historical fiction.' It notes that the ship carrying the migrants was actually only travelling from Melbourne to Sydney and, also, that four of those in Moore's photograph were Sydney residents returning from their holiday in Melbourne. ${ }^{155}$ It is significant that the photograph was shot on colour film but reprinted as monochrome, a medium associated with the documentary and presentation of evidence. Migrants arriving in Sydney is an image that rests in the forefront of an Australian consciousness, representing an idea about immigration and Australian identity, but the mismatch in the narratives it carries has come to signify something in itself for artists like Pound. It is included in The Great Exhibition alongside Alfred Stieglitz's The steerage (1907, printed 1911: NGV) [Fig. 24], which is another iteration of the migration narrative. The steerage, too, is built on a misconception. It is synonymous with the topic of immigration to the United States, but was actually taken when Stieglitz was on a cruise to Europe. ${ }^{156}$ The juxtaposition of Migrants arriving in Sydney and The steerage in The Great Exhibition provides another example of a disconnect between the actual and conveyed narratives of photographs. Here, Pound interrogates the documentary evidence of these two photographs to demonstrate how they recount a narrative built on shaky foundations.

\section{Categorising and Constraining the World}

Although seemingly ironic, the idea of constraint can be usefully applied to Pound's The Great Exhibition. The original Great Exhibition was held in London in 1851 , and concerned the categorisation and 'assemblage of all things,' in a

\footnotetext{
${ }^{154}$ National Gallery of Victoria, "Migrants Arriving in Sydney," n.d., https://nga.gov.au/federation/Detail.cfm?WorkID=77779.

${ }^{155}$ Art Gallery of New South Wales, "Migrants Arriving in Sydney," 2007, https://www.artgallery.nsw.gov.au/collection/works/429.1997/.

${ }^{156}$ Art Gallery of New South Wales, "Migrants Arriving in Sydney."
} 
celebration of the grandeur and achievements of the British Empire. ${ }^{157}$ Georges Perec, a member of the OuLiPo group, was also preoccupied with the processes of categorisation and, thus, Pound's interest in the OuLiPo group of writers becomes a guiding mechanism for The Great Exhibition. In Perec's essay 'Thoughts of Sorts / Sorts of Thoughts' (1982), he questions the methodology of categorisation used at the Exposition Universelle in Paris in 1900, which was modelled on the Great Exhibition in London of $1851 .{ }^{158}$ Perec notes that the arbitrary nature of categorisation at the Exposition Universelle was perplexing because, without a system, the 'allocation of products within these groups to their classes hold innumerable surprises. ${ }^{159}$ In practice, unforgiving categorisation enables new possibilities to be stumbled upon; a potential that Pound has seized on. As Maggie Finch writes, 'Pound is fascinated by Perec's use of restrictions in his writing as a way of encouraging new patterns and structures, and has translated some of those ideas into the formation of these collections. ${ }^{160}$

One of Pound's works, thoughts-of-sorts (2017), is obviously a nod to Perec. It is a computer programme that continuously matches one image to the next, with the kernel being an image from the NGV collection. The kernel image used by the programme is physically located in the room that thoughts-of-sorts occupies within The Great Exhibition [Fig. 25]. Starting with an object that is present in the room, the programme runs an algorithm that scours the internet for similar images and fragments of text:

The work creates the possibility of an infinitely expanding pool of image collections, acting as a reminder of the chain reactions, traces and connections which underpin the use of the internet, and the poetic limitations of trying to sort the world. ${ }^{161}$

\footnotetext{
${ }^{157}$ British Broadcasting Corporation, "The Great Exhibition of 1851, In Our Time - BBC Radio 4," BBC - The Great Exhibition, April 27, 2006, http://www.bbc.co.uk/programmes/p003c19x.

${ }^{158}$ Georges Perec, "Thoughts of Sorts / Sorts of Thoughts" [1982] in Thoughts of Sorts, trans. David Bellos (Boston, MA: David R. Godine Publisher, 2009), 124.

${ }^{159}$ Perec, "Thoughts of Sorts / Sorts of Thoughts," 125.

${ }^{160}$ Finch, "The Great Exhibition Artwork Labels," 259.

${ }^{161}$ Finch, "The Great Exhibition Artwork Labels," 258.
} 
The idiosyncrasies of visual and literal language are emphasised in thoughts-ofsorts, again reiterating this key element of Pound's practice. For him, '[a] single constraint presses us to rethink things a little, then the rest of the world sneaks in. ${ }^{162}$ The interplay and the application of constraints become mechanisms to impose order while simultaneously disrupting any recognition of pattern.

Marcel Duchamp is central in understanding the conception of the readymade or found objects. Geoffrey Batchen discusses how 'although there are nineteenthcentury precedents for this combination of practices, it is usually traced back to the advent of Marcel Duchamp's notorious readymades.' ${ }^{163}$ Let us consider one of Duchamp's earlier readymade works, Bicycle Wheel (1913, reproduced 1951: Museum of Modern Art, NY). Consisting of the front fork and wheel of a bicycle joined into a stool, the work represents the idea of creating new works of art from mass-produced items. The importance of this work is not lost on Pound, who includes a Duchampian-inspired wheel structure in The Great Exhibition's sitespecific installation, The Museum of holes (2016-17) [Fig. 26]. The incorporation of found objects in his practice, including books, ephemera, paintings, vernacular photographs, recalls a Duchampian approach to art-making.

Duchamp was, however, 'never able to arrive at a definition or explanation' of the readymade. ${ }^{164}$ On the other hand, his contemporary, André Breton, defines the readymade in the Dictionnaire albrégé du surréalisme as 'manufactured objects promoted to the dignity of art through the choice of the artist. ${ }^{165}$ This echoes how Georges Perec used 'fragment as a literary form,' whether gathered from preexisting text or collated together. ${ }^{166}$ We can see the use of the readymade put into

\footnotetext{
${ }^{162}$ Finch, 168.

${ }^{163}$ Batchen, "Keepers: Patrick Pound and the Art of Collecting," 35.

164 Thomas Girst, The Duchamp Dictionary (London, UK: Thames \& Hudson, 2014), 154.

${ }^{165}$ Girst, The Duchamp Dictionary, 154.

${ }^{166}$ Geroges Perec, Thoughts of Sorts [1982], trans. David Bellos (Boston, MA: David R. Godine Publisher, 2009), xi.
} 
practice by Pound in thoughts-of-sorts, as well as in the curation of The Great Exhibition.

Duchamp and Pound both use language and puns in a manner that recalls the French poet Raymond Roussel's method of writing, which also profoundly influenced both the Surrealists and the OuLiPo group of writers. On his methodology, Roussel writes:

I chose two almost-identical words (reminiscent of metagrams). For example, billard [billiard table] and pillard [plunderer]. To these I added similar words capable of two meanings, thus obtaining two almost identical phrases. In the case of billard and pillard the two phrases I obtained were: 1. Les lettres du blanc sur les bandes du vieux billard... [The white letters on the cushions of the old billard table...] 2. Les lettres du blanc sur les bandes du vieux pillard... [The white man's letters on the hordes of the old plunderer... $]^{167}$

Here, Raymond Roussel demonstrates how the obscure subtleties of the French language can be used to shift meaning. Language is used by Roussel as a mechanism to exploit its own structural limitations or, alternatively, to create new possibilities. Duchamp wrote that Roussel's methodology and use of language games 'was an obscurity of another order' and considered as a precursor to the OuLiPo movement, of which Duchamp was also a member. ${ }^{168}$ This exploitation of language is noted here by d'Harmoncourt: 'One of Duchamp's favorite devices, operates on a principle of inframince by containing two or more meanings within one phrase - the thriftiest use of language based on tiny shifts of sound or spelling.' ${ }^{169}$ Pound is noteworthy for his puns and subtle use of language that shifts and buckles in different contexts. For instance, a work in The Great Exhibition titled Some French things (2014) consists of found items with 'Les Choses' written on one of them - the reason being that 'Les Choses' translates to 'things' in French.

${ }^{167}$ Raymond Roussel, How I Wrote Certain Of My Books, ed. Trevor Winkfield (Boston, MA: Exact Change, 1995), 3-4.

${ }^{168}$ Pierre Cabanne, Dialogues with Marcel Duchamp, trans. Ron Padgett (London, UK: Thames \& Hudson, 1971), 41.

${ }^{169}$ Anne d'Harnoncourt and Kynaston McShine, eds., Marcel Duchamp (Munich, Germany: Prestel-Verlag, 1989), 37. 
Within this collection was the book Les Choses (1965), a novel by Georges Perec that 'reflected the development of language studies and sociology and owed much to Barthes' Mythologies.' 170

Marcel Duchamp's Fountain (1917) presents us with an artwork directly associated with the use of the readymade. It is a urinal turned on the side, with the signature 'R. Mutt' embellished on the front. According to Elena Filipovic, Fountain is 'already long processed by art history. ${ }^{171}$ I do not intend to supplement the conversation surrounding Duchamp's important work but, rather, use it as an example of his 'deep preoccupation with the institutional sites, mechanisms, and conventions' that pervade the art world. ${ }^{172}$ By being signalled and accepted as an artwork, Fountain contributed to a disruption to the art world. As Batchen highlights: '[t]he shifting of a studiously ordinary, even vulgar, mass-produced object into the rarefied confines of the art world punctured the self-certainty of that world's value system. ${ }^{173}$ Both Bicycle Wheel and Fountain demonstrate that the readymade object is the genesis of a deliberative found-object art practice. They also establish that 'the readymade is not only an object selected and nominated but, perhaps even more importantly, one that is curated,' which is critical when situating Pound's practice into the paradigm of artist-as-curator. ${ }^{174}$ Despite this, Pound is reluctant to be ascribed the label of 'curator.' 175

Marcel Duchamp wrote: 'I'm not at all sure that the concept of the readymade isn't the most important single idea to come out of my work. ${ }^{176}$ Pound echoes this sentiment, often citing William Carlos Williams' 'No ideas but in things' as a

\footnotetext{
${ }^{170}$ Mireille Ribière, "Georges Perec's Enduring Presence in the Visual Arts," in The Afterlives of Georges Perec, ed. Rowan Wilken and Justin Clemens (Edinburgh, UK: Edinburgh University Press, 2017), 26.

${ }^{171}$ Filipovic, The Apparently Marginal Activities of Marcel Duchamp, 5.

${ }^{172}$ Filipovic, 4.

${ }^{173}$ Batchen, "Keepers: Patrick Pound and the Art of Collecting," 36.

${ }^{174}$ Filipovic, The Apparently Marginal Activities of Marcel Duchamp, 6.

${ }^{175}$ Finch, "The Great Exhibition Artwork Labels," 2017, 16.

176 Girst, The Duchamp Dictionary, 2014, 154.
} 
guiding principle for his practice. ${ }^{177}$ The conceptualisation of the object is a central tenet of Duchamp and Dadaism - the anti-aestheticism and irony stands in lieu of the beautiful. As I show in subsequent chapters, the elevation of 'things' is a concept that Pound embraces in The Great Exhibition.

${ }^{177}$ Finch, "The Great Exhibition Artwork Labels," 260. 


\title{
Chapter Two: Vernacular Photography
}

\author{
Each photo offers the possibility of completing a set; as if to photograph is to \\ work at a solution, of a type. It's as though, if we could only get all the pieces \\ together we could solve the puzzle. This is a condition of collecting. ${ }^{1}$ \\ Patrick Pound
}

\begin{abstract}
A key characteristic of Patrick Pound's practice is his use of vernacular photography. In this chapter I provide the context for his use of over 4,000 vernacular photographs throughout The Great Exhibition by tracing the proliferation of vernacular photography within art practices. Situating Pound in relation to these practices highlights the similarities and differences in his methodology of collection, categorisation and curation of vernacular photography.
\end{abstract}

It is necessary to begin this chapter by defining the terms 'vernacular photography' and 'snapshot,' to clarify how those terminologies operate in relation to photography. In order to contextualise Pound's use of vernacular photography, it is crucial to understand the pivotal role snapshots play within our lives, both personally and collectively. Geoffrey Batchen guides my definition here and I also draw on the work of the following photographic theorists to supplement this definition: Roland Barthes helps us understand the potency of photography and Pierre Bourdieu argues that snapshots and photographic albums fulfil a societal function. Once a working definition of 'vernacular photography' has been established through the scholarship of relevant theorists and literature, I will be able to provide a framework within which to interpret The Great Exhibition.

The magnitude of The Great Exhibition is a reflection of the proliferation of the endless torrent of photography within our lives. Therefore, it comes as no surprise that the use of vernacular photography by artists is not a new phenomenon. It is, therefore, essential to trace key artists working in a similar way to Pound. Of note is

${ }^{1}$ Pound, "The Gallery of Air." 
the practice of Erik Kessel (1966-), an artist who specialises in publishing found and vernacular photography. Joachim Schmid (1955-) has been working with found photography since the 1980s and foregrounds many of the tropes that Kessels is engaged with. Positioning Pound in relation to these practices will contextualise his collecting of vernacular photography and the curatorial process it then undergoes.

I explore the concept of the archive and position it in relation to one of the functions that photography occupies - as a marker of memory. This can be seen in Walker Evans's collection of photographic ephemera, as well as Schmid and Kessels' collecting. Pound's collection of vernacular photography also functions as an archive on display in The Great Exhibition. What these archives have in common is the ability to connote collective memories. To conclude this chapter, I discuss some of the similarities between Marcel Duchamp's conceptualisation of the archive in his Boîte-en-valise (1935-1940) and Pound's The game of things (2016).

\section{Defining the Vernacular}

The term 'vernacular' has been used to define both the 'indigenous' and 'ordinary' attributes of photographs, until becoming a descriptor that, as Geoffrey Batchen suggests, 'could conceivably be applied to any photograph. ${ }^{2}$ Indeed, in a contemporary environment saturated with images, it is conceivable to propose that vernacular photography is constantly permeating around us.

Batchen argues that the term, 'vernacular photography' has only relatively recently started to proliferate in the discourse surrounding photographic histories and is now applied as a catch-all category. ${ }^{34} \mathrm{He}$ observes that ' $[\mathrm{v}]$ ernacular photographs represent the visual culture of everyday life, sometimes poignant and creative but

\footnotetext{
${ }^{2}$ Geoffrey Batchen, "Vernacular Photography," Grove Art Online - Oxford Art Online, January 22, 2014, http://www.oxfordartonline.com/subscriber/article/grove/art/T2254188.

${ }^{3}$ Batchen, "Vernacular Photography," January 22, 2014.

${ }^{4}$ Ibid.
} 
more often banal and utilitarian. ${ }^{5}$ So what does the term vernacular photography mean, and how do these photographs actually manifest its characteristics? Photodealer Daile Kaplan proposes 'that a vernacular photograph is one produced by an untrained maker, usually an amateur photographer,' and ascribes its intent as 'communicative, versus artistic.' 6 The application of the term vernacular photography has, according to photography curator Douglas Nickel, devolved 'to this grab-bag left over category ... Vernacular is, thus, defined not by what it is but what it isn't.' ${ }^{7}$ This tension is reiterated by Batchen, who states that the nature of vernacular photographs is that they 'resist this kind of classification, tending to be made in vast numbers by anonymous, amateur, working-class and sometimes even collective hands, or worse, by crass commercial profiteers. ${ }^{8}$ Batchen goes further, describing vernacular photographs as 'art history's worst nightmare,' because they are 'boring pictures.' ${ }^{9}$ In consideration of these definitions, I use the term 'vernacular photography' to encompass a wide array of photographs made by anonymous or amateur photographers, press photographs, commercial or editorial photography, and neglected genres of photography. They are the visual detritus of everyday life compounded into a single category - the snapshot. The Great Exhibition is premised on the idea that these photographs can be elevated through their inclusion to identifiable categories based on subject, not medium.

It is the retrieval of these histories through exhibitions and publications like The Great Exhibition that is important here. If art history has previously categorised vernacular photography as photography's 'other' history, then its elevation to the art gallery is of interest. ${ }^{10}$ According to Batchen, 'vernacular photographies have attracted so little attention in the traditional account of photography's history' because '... most histories have tenaciously focused on the artistic ambitions of the

\footnotetext{
${ }^{5}$ Batchen, "Vernacular Photography."

${ }^{6}$ Daile Kaplan in Geoffrey Batchen, ed., "Vernacular Photographies: Responses to a Questionnaire," History of Photography 24, no. 3 (2000.): 229.

${ }^{7}$ Douglas Nickel, in ibid.

${ }^{8}$ Geoffrey Batchen, "Vernacular Photography," History of Photography 24, no. 3 (2000): 262.

${ }^{9}$ Geoffrey Batchen, "Snapshots: Art History and the Ethnographic Turn," Photographies 1, no. 2 (2008): 121.

${ }^{10}$ Ibid.
} 
medium, excluding all other genres except as they complement a formalist arthistorical narrative. ${ }^{11}$ There are, then, two questions to be answered: why did 'art history' reject the snapshot, and why has it become increasingly popular for artists and institutions to show them? Batchen explains:

The reasons are obvious: most snapshots are cloyingly sentimental in content and repetitively uncreative as pictures, having little value in the marketplace of either ideas or commodities. For all these reasons, they don't easily fit into a historical narrative still anxiously, insecurely, focused on originality, innovation, and individualism. $^{12}$

Despite the ubiquity of family snapshots as a genre, they barely appear in most standard histories of photography. The utilitarian and accessible nature of vernacular photography precludes the genre from inclusion within a narrativecentric art history because, quite often, the photographs are shot by unknown amateurs.

The art market can be considered as a significant force fuelling the revitalisation of vernacular photography as a category in its own right, in part because it has been 'quick to exploit the vernacular photograph's capacity for decontextualization and displacement. ${ }^{13}$ This apparent flexibility is an issue for some curators as anthropologist Elizabeth Edwards explains:

I have big problems with some vernacular photographs being shown in 'art' contexts, especially cross-culturally where there is a tendency to collapse everything into neo-exoticism ... there is a tendency to absorb them into the established discourses rather than what is culturally specific and relevant about this particular body of work. ${ }^{14}$

The insertion of vernacular photography into art contexts is exemplified in the elevation of the work of Mike Disfarmer (1884-1959) - a studio photographer from

\footnotetext{
${ }^{11}$ Batchen, "Vernacular Photography," 262.

${ }^{12}$ Batchen, "Snapshots," 123-24.

${ }^{13}$ Batchen, "Vernacular Photography," January 22, 2014.

${ }^{14}$ Elizabeth Edwards, in Batchen, ed., "Vernacular Photographies: Responses to a Questionnaire," 231.
} 
Heber Springs, Arkansas. Nearly twenty years after Disfarmer's death in 1977, his photographs were ' $[\mathrm{r}]$ eprinted from their original negatives and enlarged for the art museum wall.' ${ }^{15}$ Collectors also began acquiring Disfarmer's vintage prints because they were 'authentic' and 'closer to the way the photographer wanted [the photograph] to look. ${ }^{16}$ One of the motivations for this reclamation of Disfarmer's archive was that '[New York art dealers] instantly create[d] a new market for material that was previously unknown. ${ }^{17}$ With an identifiable oeuvre, Disfarmer's photographs made the transition to the museum with their 'formal elements' being read to 'anticipate modernist aesthetics.' ${ }^{18}$ The danger here is that Disfarmer's photographs were 'absorbed' into an aesthetic discourse, rather than used to explore the social functions that those vernacular photographs performed for their communities:

Once extracted from a vernacular album and relocated to a gallery or museum, moreover, a photograph can no longer activate conversations, memories, and feelings specific to the social contexts for which it was created. ${ }^{19}$

Where does this leave The Great Exhibition? As an exhibition, it relies on vernacular photography and the NGV's collection items 'being "unhinged" from their original context' ${ }^{20}$ To answer the criticism that the displacement of those photographs from their original context is 'neo-exoticism' in practice, we must look at the way The Great Exhibition operates by analysing how vernacular photographs are displayed. The photographs that Pound included in The Great Exhibition are not elevated to the status of 'art' in the way that Edwards and Sheehan describe. Pound states that he tries to 'avoid artfulness and mannerism and affectation' in his work. ${ }^{21}$ The 4,000 vernacular photographs he uses still operate within the

\footnotetext{
${ }^{15}$ Tanya Sheehan, "Ordinary Masters: Mike Disfarmer and the Reclamation of Vernacular Photography and Afterword," in Becoming Disfarmer, ed. Chelsea Spengemann (New York, NY: Neuberger Museum of Art, 2014), 104.

${ }^{16}$ Ibid.

${ }^{17}$ Edwynn Houk cited in Sheehan, 106.

${ }^{18}$ Sheehan, 105.

${ }^{19}$ Sheehan, 108.

${ }^{20}$ Finch, "The Great Exhibition Artwork Labels," 20.

${ }^{21}$ Finch, "A Conversation: Patrick Pound and Maggie Finch," 28.
} 
framework of the vernacular photograph - they are ordinary, boring and repetitive. What, then, is the allure of using vernacular photographs for artists like Pound? The answer may be found in The Great Exhibition's ability to reconcile shared narratives and histories by examining vernacular photographs as a genre.

The emergence and subsequent popularity of snapshot photography can be traced back to the technological innovations of the Eastman Kodak Company, which was founded in $1888 .^{22}$ George Eastman purchased the patents for roll film technology and began manufacturing cameras suitable for use by amateur photographers. Before these developments, photography was a laborious and expensive process. The advent of the hand-held camera and inexpensive film revolutionised its practice. Furthermore, Eastman Kodak developed a mail-order service, developing and printing the film negatives and re-loading the film in the camera before sending it back to their customers. Their slogan was: 'You press the button, we do the rest,' which 'effectively industrialized a division of labor by divorcing the capturing of the image from its printing. ${ }^{23}$ In 1900, Kodak's handheld camera, the Box Brownie, was introduced to the North American market. Portable cameras like the Box Brownie, coupled with a mail-order printing service, increased the accessibility of photographic technologies to the middle classes. Batchen suggests that the company's astute marketing was critical to Kodak's success:

Urging women to become the family's historian, Kodak aggressively associated the snapshot with memory and loss, and with specifically middle-class values and sentiments, and insisted that photography be regarded as an essential part of everyday life. ${ }^{24}$

Photography was no longer exclusive to the professional photographer or wealthy hobbyist; amateur photographers began utilising photography within a domestic setting. The 'aesthetic associated with early snapshots' was termed "Kodak" culture' because of the repetition of visual tropes by its users. ${ }^{25}$ Vernacular

\footnotetext{
${ }^{22}$ Batchen, "Snapshots," 130.

${ }^{23}$ Palmer, Photography and Collaboration: From Conceptual Art to Crowdsourcing, 6.

${ }^{24}$ Batchen, "Snapshots," 130.

${ }^{25}$ Sheehan, "Ordinary Masters," 110.
} 
photography became an accessible means to document daily life, especially among the burgeoning middle classes.

Who were these amateur photographers? Kodak's encouragement of women to become the ritualistic family historians may have created a 'sexual division of photographic tasks and interests' at least according to Pierre Bourdieu. ${ }^{26}$ At that time, women were confined to the "traditional uses to which their "femininity" has "predestined" them' - the domestic. ${ }^{27}$ One function of photography was to document the family unit in order to solidify the group. ${ }^{28}$ Kodak's aggressive marketing for women to be the 'family historian' was aided by the popularisation of the 'Kodak Girl.' Throughout the early twentieth century, the Kodak Girl was a characterisation used to market Kodak to women. This gendered association with snapshot photography and the domestic sphere may in turn have engendered snapshot photography as feminine. The implication here is that snapshot photography belonged to the realm of amateur photographers who were also women.

This gendering of the medium can be observed in Pound's site-specific installation, The photographer's shadow (2000-2017) in The Great Exhibition [Fig. 27]. Each of the 117 vernacular photographs in this installation includes the shadow of the photographer. In many of the photographs, a shadow with a narrow waist or of a figure wearing a dress enters the frame. Take the photograph, for example, of a couple posing for a picture, leaning against a car parked on the verge [Fig. 28]. The photographer is present in the form of her shadow but is simultaneously absent. The couple, too, are removed from the frame, as their heads have been carefully removed - leaving a circular trail where the scissors have cut them out. In another photograph, a Samoyed dog with its jaws ajar faces the photographer [Fig. 29]. A blur takes up the left-hand side of the frame; an appendage belonging to the

\footnotetext{
${ }^{26}$ Pierre Bourdieu et al., Photography: A Middle-brow Art, trans. Shaun Whiteside (Cambridge, UK: Polity Press, 1990), 40.

${ }^{27}$ Ibid.

${ }^{28}$ Bourdieu, 30.
} 
photographer must have accidently slipped in front of the lens as the shutter was pressed. The mistake is almost invisible because the shadow of the photographer abruptly fractures the composition. While a reductive stereotype, we can assume from the shape of the shadow that the photographer is a woman. Her shadow is positioned next to the dog as though 'the appearance of this shadow adds the binary of life and death to this photograph's already dense array of possible meanings. ${ }^{29}$ The photographer's shadow is an installation that probes photography's hidden amateur photographers - the absent and those made visible through the presence of a shadow. These 'accidental portraits of the photographer haunt the photographic record. ${ }^{30}$

The display of shadows in photography is also not unique. It might be said that the very premise for the invention of photography was to about the 'art of fixing a shadow. ${ }^{31}$ In his manuscript, Some Account of the Art of Photogenic Drawing, Talbot explains how photogenic drawing captures 'the most transitory of things, a shadow, the proverbial emblem of all that is fleeting and momentary... ${ }^{32}$ The exhibition Suspending Time: Life-Photography-Death, curated by Geoffrey Batchen for the Izu Photo Museum in 2010, dedicated an entire gallery to the display of snapshots featuring the shadow of the photographer. ${ }^{33}$ In that gallery there were 95 snapshots with a shadow, flanked by a Lee Friedlander photograph and a Daido Moriyama photograph that both featured their own shadows. ${ }^{34}$ The history of the snapshot can be explored with the trope of the shadow signifying a commonality between the vast numbers of snapshots that exist. ${ }^{35}$ Pound's use of the

\footnotetext{
${ }^{29}$ Geoffrey Batchen, "Life and Death," in Suspending Time: Life-Photography-Death, ed. Yoko Mori (Nagaizumi-Cho, Shizuoka: Izu Photo Museum Nohara, 2010), 124.

${ }^{30}$ Anna Newbold cited in Daniel Palmer, "The Mistake of Photography: Patrick Pound, Jackson Eaton and the Paradoxical Self Image," Dissect 2 (2015): 25.

${ }^{31}$ William Henry Fox Talbot, Some Account Of The Art Of Photogenic Drawing, Or The Process By Which Natural Objects May Be Made To Delineate Themselves Without The Aid Of The Artist's Pencil (London, UK: R. \& J. E. Taylor, Red Lion Court, 1839), 6.

${ }^{32}$ Ibid.

${ }^{33}$ Cecilia Grönberg, "Photography, History, Curating - a Conversation with Geoffrey Batchen. CUNY Grad Center, New York, May 5 2010,” OEI 53-54 (2011): 512.

${ }^{34}$ Grönberg, 513.

${ }^{35}$ Ibid.
} 
shadow could be seen as an extension of this history of curating the shadow - a repetition of a repetition.

\section{The Function of Snapshots}

Sociologist Pierre Bourdieu reiterates the notion that photography's popularity is due to its economic accessibility and lack of technical obstacles for the operator. ${ }^{36}$ Bourdieu suggests that "photography is the most ordinary thing of all because of the existence of cheap cameras which are easy to use, and because the inclination to use them is not the product of training or education. ${ }^{37}$ Snapshots exist in our lives as physical markers of memory. They are found in photographic albums, in jewellery, our wallets and on the walls of our homes, demonstrating our shared desire to connect with photographs as sites of memory.

According to Bourdieu, what makes a snapshot a snapshot is the function it serves. Snapshots 'evoke and communicate the memory of events which deserve to be preserved. ${ }^{38}$ A photographic album, for instance, functions to unify the family unit because it 'expresses the essence of social memory. ${ }^{39} \mathrm{He}$ argues that, 'while seeming to evoke the past, photography actually exorcizes it,' the snapshot resurrecting memories to generate a cohesion within the group. ${ }^{40}$ In this regard, The Great Exhibition asks us to consider two things: what is the function of family snapshots when they are displaced from their original context, and what do they convey when viewed together in The Great Exhibition?

For Pound, the vernacular photographs included in The Great Exhibition are markers of a world memory and 'that picture is a concertina of the photographed world at different times. ${ }^{41}$ Their original function, as markers of social memory as

\footnotetext{
${ }^{36}$ Bourdieu, Photography, 14.

${ }^{37}$ Bourdieu, 47.

${ }^{38}$ Bourdieu, 31.

${ }^{39}$ Bourdieu, 30.

${ }^{40}$ Bourdieu, 31.

${ }^{41}$ Finch, "A Conversation: Patrick Pound and Maggie Finch," 21.
} 
suggested by Bourdieu, shifts when snapshots are taken out of their original context and exhibited within the NGV by Pound. Take, for example, the first photograph in The Great Exhibition on the ground level of the Ian Potter Centre. The snapshot sits on one of eight plinths placed in an arch formation, guiding visitors to the entrance of The Great Exhibition [Fig. 30]. The palm-sized monochrome photographic print levitates within its glass enclosure. Looking closer, we see twins linking arms, with their backs to us. Unbeknownst to the two women pictured, Pound has positioned them within his site-specific installation, The entrants (2016-17), so they lead us to the entrance of The Great Exhibition. On one hand, the photograph's original function, 'to be shown' and be 'looked at,' has not altered - it is still being shown and looked at. ${ }^{42}$ However, in its previous life the photograph was 'defined by the personal relationship that links [the subject] to the photographer or viewer.' Now it is void of that connection. ${ }^{43}$ Placed in The Great Exhibition, the photograph shifts from a memory to being 'exorcised' from that memory - to become an anonymous snapshot seen by visitors to the NGV. This ordinary photograph of two women has shifted from a 'private' image to a 'public' one as a result of its new context. ${ }^{44}$

\section{Photographic Memory}

One of the functions of the vernacular snapshot in The entrants is to signify meaning through its new context. For Pound, this inherent quality is what attracts him to use snapshots throughout his practice:

Essentially I am interested in photography because of its documentary qualities, its matter-of-factness. ... Photography is the medium of record. Photography is, at its core, an indexical medium. The camera's default position is to record what is in front of it. ${ }^{45}$

Photographs provide a material record of memories. Their arrangement within The Great Exhibition interrogates how that meaning alters within new contexts.

\footnotetext{
${ }^{42}$ Bourdieu, Photography, 88.

${ }^{43}$ Ibid.

${ }^{44}$ Batchen, "Snapshots," 133.

${ }^{45}$ Finch, "A Conversation: Patrick Pound and Maggie Finch,” 26.
} 
Functioning as a talisman for memories, photographs become imbued with a sort of 'magic.' In Talbot's manuscript, Some Account of the Art of Photogenic Drawing (1839), he attributes 'natural magic' to the newfound ability to 'fix shadows. ${ }^{46}$ Art historian W. J. T. Mitchell provides an apt example of the 'magic' held by photographs: 'Everyone knows that a photograph of their mother is not alive, but they will still be reluctant to deface or destroy it. ${ }^{47}$

Roland Barthes expresses the essence of this 'magic' when he refers to the Winter Garden photograph throughout his text Camera Lucida (1980). A central tenet of Barthes' argument is that the Winter Garden photograph exists as an 'ordinary' and 'indifferent picture. ${ }^{48}$ Barthes describes the photograph depicting his mother as a young girl as achieving 'the impossible science of the unique being. ${ }^{49}$ The implication is that science and truth elevate the photograph of his mother to an object vested with meaning. We might well ask why this is so. For Barthes, the difference between a photograph and a painting is that "no painted portrait, supposing that it seemed "true" to me, could compel me to believe its referent had really existed. ${ }^{50}$ Barthes shares this realisation on the first page of Camera Lucida where he describes looking at a photograph of Jerome, Napoleon's brother: '... I realized then, with an amazement I have not been able to lessen since: "I am looking at eyes that looked at the Emperor." ${ }^{51}$ His amazement is also translated to the Winter Garden photograph because ' $[\mathrm{t}]$ he photograph is literally an emanation of the referent. From a real body, which was there, proceed radiations which ultimately touch me. ${ }^{52}$ The Winter Garden photograph is, therefore, an emanation of his mother. Rather than reproduce the picture in the book, Barthes leaves us to imagine our own version of the Winter Garden photograph: a photograph that to

${ }^{46}$ Talbot cited in Batchen, Each Wild Idea, 11.

${ }^{47}$ W. J. T. Mitchell, What Do Pictures Want? (Chicago, IL; London, UK: The University of Chicago Press, 2005), 31.

${ }^{48}$ Roland Barthes, Camera Lucida: Reflections on Photography, trans. Richard Howard (New York, NY: Hill and Wang, 1981), 73.

${ }^{49}$ Barthes, 71.

${ }^{50}$ Barthes, 77.

${ }^{51}$ Barthes, 3 .

${ }^{52}$ Barthes, 80. 
other observers would be meaningless, but to us has become an object vested in meaning.

Barthes' Camera Lucida is a useful reference point in any discussion about photography. The text's importance is evident in its repeated republication and translation from the original French into 17 different languages. ${ }^{53}$ The text is frequently cited as it is "perhaps the most influential book ever published on photography. ${ }^{54}$ Photography Degree Zero: Reflections on Roland Barthes's Camera Lucida, for example, which was published in 2009, is an anthology of essays responding to Camera Lucida. The relevance of Camera Lucida is made salient through publications like Photography Degree Zero, which reflects Barthes' ongoing influence within photographic history.

Barthes employs two terms to explain some of the effects of photography on a viewer. He uses the term studium as 'that very wide field of unconcerned desire, of various, of inconsequential taste,' with reference to banal and utilitarian photographs. ${ }^{55}$ The second term, which Barthes employs to complement studium, is punctum: 'A photograph's punctum is that accident which pricks me (but also bruises me, is poignant to me). ${ }^{56}$ The Winter Garden is a photograph that is void of meaning to us, our studium, but for Barthes, exists as his punctum. The 'detail' is often what 'pricks. ${ }^{, 57}$ The Winter Garden photograph exemplifies the inseparable nature of the two effects that every photograph contains.

53 Geoffrey Batchen, "Palinode: An Introduction to Photography Degree Zero," in Photography Degree Zero: Reflections on Roland Barthes's Camera Lucida, ed. Geoffrey Batchen (Cambridge, MA: MIT Press, 2009), 15.

${ }^{54}$ Front-end leaf in Photography Degree Zero: Reflections on Roland Barthes's Camera Lucida.

55 Barthes, Camera Lucida, 27.

56 Ibid.

${ }^{57}$ Barthes, 47. 
Camera Lucida, as Geoffrey Batchen argues, 'produces a history that is actually about photography and not just of photographs. ${ }^{58}$ Arranged in two parts, each comprising 24 sections, it operates as a 'mirror image' or a 'palinode. ${ }^{59}$ This structure references the very nature of a photograph; a positive and a negative, absence and presence, there and not there, a studium and a punctum - a binary.

Camera Lucida is, in addition, a rumination on death - about the betrayal of time. Barthes proclaims there is a 'new punctum' perforating every photograph and that is 'Time. ${ }^{60}$ One of the reproductions is Alexander Gardner's Portrait of Lewis Payne (1865), who was photographed in his cell 'where he was waiting to be hanged.' ${ }^{61}$ The caption underneath the photograph reads: 'He is dead and he is going to die ... ${ }^{62}$ Barthes writes that what is at stake is 'death. ${ }^{63}$ We know Lewis Payne is dead (the photograph was taken in 1865), but we also know he is going to die (as he is awaiting his hanging).

Pound's awareness of the relationship between death and photography is evident in his site-specific installation, The sleeping gallery (2016-2017). The installation occupies the last of the seven galleries in The Great Exhibition - the darkened room a stark contrast from the light-filled galleries preceding it. On the opposite side of the entrance, the site-specific installation People who look dead but (probably) aren't (2011-2014) (NGV: Melbourne, VIC) floats against the wall in a cloud formation [Fig. 31]. While it is one of Pound's installations, it is also part of the NGV's collection - purchased in 2014. The brief reprieve of the darkened space is punctured as soon as you view People who look dead but (probably) aren't. In the installation is a photograph of a man, slumped over in the driver's seat of his car after a crash, conjures an uneasy suspicion that perhaps he is injured but (probably)

${ }^{58}$ Geoffrey Batchen, "Camera Lucida: Another Little History of Photography," in Photography Degree Zero: Reflections on Roland Barthes's Camera Lucida, ed. Geoffrey Batchen (Cambridge, MA: MIT Press, 2009), 269.

59 Batchen, "Camera Lucida," 260.

${ }^{60}$ Barthes, Camera Lucida, 96.

${ }^{61}$ Ibid.

${ }^{62}$ Barthes, Camera Lucida, 95.

${ }^{63}$ Barthes, 96. 
is not dead. A photograph of a woman being buried in the sand up to her neck triggers a familiar memory. She is obviously not dead, despite the burial ritual performed by her friend. There is a photograph of a woman lying in a coffin adorned by an ornate white trim - her eyes are closed, her lips are pale and you quickly arrive at the uncomfortable realisation that she is (probably) dead. In the accompanying wall text Pound writes: 'Photography stops people in their tracks. Eventually every photograph is a photograph of a dead person. The camera is an idling hearse. ${ }^{64}$ As Roland Barthes alluded in Camera Lucida, the ultimate punctum is death: 'Whether or not the subject is already dead, every photograph is a catastrophe. ${ }^{65}$

The puzzle we are trying to solve in People who look dead but (probably) aren't is whether or not the people in the photographs are actually dead, or just sleeping. As Pound predicts, '[e]ventually every photograph is a photograph of a dead person.' Susan Sontag reiterates that ' $[p]$ hotographs state the innocence, the vulnerability of lives heading toward their own destruction, and this link between photography and death still haunts all photographs of people. ${ }^{66}$ Yet photography has been associated with death since its inception. The daguerreotype was considered 'black magic,' to the extent that 'Balzac was one person who had an "intense fear" of being photographed. ${ }^{67}$ Early photographic processes sometimes required subjects to hold their pose for minutes as the photograph was being taken, resulting in a corpse-like appearance. ${ }^{68}$ Ironically, posthumous photography emerged as a burgeoning market so 'an image of the dead as dead [which] somehow worked to sustain the living.' 69 Pound's installation, People who look dead but (probably) aren't, operates as a reminder of photography's historical relationship to death. In every photograph of a dead person, the subject is dead - just as every living person in any photograph is going to die. For a moment, as we contemplate the series of vernacular photographs

\footnotetext{
${ }^{64}$ Finch, "The Great Exhibition Artwork Labels," 334.

${ }^{65}$ Barthes, Camera Lucida, 96.

${ }^{66}$ Sontag, On Photography, 70.

${ }^{67}$ Batchen, Each Wild Idea: Writing, Photography, History, 130.

${ }^{68}$ Ibid.

${ }^{69}$ Ibid.
} 
in front of us, we, too, can lie down on the circular couch in front of the installation and reflect the pose of the figures in The sleeping gallery.

The desire to take photographs, to freeze time, and ensure that memories survive is a reflection of an anxiety around mortality. The reluctance to destroy a photograph, as Mitchell observed, can be explained by Barthes' connection to the photograph of his mother in the Winter Garden. Pound explores this inherent reluctance in one of his site-specific installations in The Great Exhibition. Damaged (2008-2017) consists of fifty or so photographs lying flat within a vitrine. Some of the photographs have perfectly oval shapes cut out where a face once was; some photographs have clearly been punctured with sharp objects where faces should be and some have whole bodies removed from the photograph - leaving just a blank space. One photograph from the Damaged collection has been used as the cover of the exhibition catalogue accompanying The Great Exhibition [Fig. 32]. In the photograph, a shirtless man is captured walking on a track in the sand dunes. The vestiges of a cigarette burn emanate from where the man's face should be. The destruction of the man's face has erased it from the material record in one emotionally charged cathartic act. If we take Barthes' premise that the 'truth' of a person can be found in a photograph then disrupting that essence through literal defacement is an act of symbolic violence.

Some of the photographs in Damaged are not damaged out of animosity, however, but out of love. The practice of wearing jewellery incorporating the portraits of loved ones dates back to the 1600 s but became widespread with the advent of photography. ${ }^{70}$ Geoffrey Batchen writes:

It was logical that, following the introduction of photography in 1839, calotypes, daguerreotypes, ambrotypes, tintypes, and albumen prints would also find their way into pins, rings, pendants, brooches, and bracelets that were then so fashionable. $^{71}$

\footnotetext{
${ }^{70}$ Geoffrey Batchen, Forget Me Not: Photography \& Remembrance (New York, NY: Princeton Architectural Press, 2004), 34.

${ }^{71}$ Ibid.
} 
Evidence of the careful cutting out of a face from of a photograph is considered a sign that it may be now residing in a piece of jewellery, like a locket or brooch. Carrying around a picture of a loved one close to one's body is an intimate act, although it is somewhat ironic that, in order to do this, the photograph of the person must undergo a beheading. The Damaged series demonstrates the marked differences in the ways of and reasons for damaging photographs, which has ultimately led to their disposal on the second-hand market and subsequent collection by Pound.

\section{'An Endless Torrent'}

The announcement of the invention of the daguerreotype by Daguerre in 1839 was the 'official' beginning of the photographic inventory. ${ }^{72}$ While the task of quantifying how many photographs have been taken since then is impossible, it is clear that the number of photographs in existence is continually escalating. The evolution of photography and subsequent uptake of its technologies, from the first daguerreotypes, the Box Brownie, the Instamatic camera, the first digital cameras and the Smartphone, has resulted in a sharp incline of the number of photographs in existence. At the turn of the twenty-first century, Kodak's annual report announced that there had been 80 billion photographs taken worldwide. ${ }^{73}$ Of course, the estimates are rough but the growth of photographs taken annually is exponential. In 2014 , it was reported that 1.8 billion photographs were uploaded online daily, totalling around 657 billion photographs per annum. ${ }^{74}$ These figures are, however, already outdated. The latest estimate is that 1.3 trillion images were taken in $2017 .{ }^{75}$ This figure does not, however, include images stored offline, those that are deleted

\footnotetext{
${ }^{72}$ Sontag, On Photography, 3.

${ }^{73}$ Stephen Heyman, "Photos, Photos Everywhere," The New York Times, January 19, 2018, sec. Arts, https://www.nytimes.com/2015/07/23/arts/international/photos-photos-everywhere.html.

${ }^{74}$ Rose Eveleth, "How Many Photographs of You Are Out There In the World?," The Atlantic, February 11, 2015, https://www.theatlantic.com/technology/archive/2015/11/how-manyphotographs-of-you-are-out-there-in-the-world/413389/.

${ }^{75}$ Heyman, "Photos, Photos Everywhere."
} 
before being uploaded or images from surveillance cameras and satellites, to note just a few exceptions. As Sontag predicted, this proliferation is now part of the 'image-world that bids to outlast us all. ${ }^{76}$ Photographic production in the nineteenth century, as experienced by Daguerre or Talbot, can be considered a drop in the ocean compared to today's 'endless torrent' of image production. ${ }^{77}$

Dutch artist Erik Kessels focusses intensely on the mass-dissemination of photographs that are uploaded online. His practice has evolved from working as a window-dresser, to being an artist, curator, editor, collector and art director of his advertising agency, KesselsKramer. Kessels' interest in amateur photography began when he started to purchase family albums at second-hand markets. After picking up on the thematic quirks of each album, Kessels started to publish these photographs as series.

Two series of note that Kessels has published are IN ALMOST EVERY PICTURE and USEFUL PHOTOGRAPHY. The first iteration of IN ALMOST EVERY PICTURE uses hundreds of discarded photographs, which Kessels purchased from a market in Barcelona. The book consists of 'photos taken by a husband of his wife during the years 1956 to 1968, chosen for their "remarkable consistency." 78 As the years pass, the woman continues to appear in each photograph but gradually decreases in size - like a diminishing love. In the book USEFUL PHOTOGRAPHY \#001, Kessels pulls anonymous photographs from 'sales catalogues, instruction manuals, packaging, brochures and textbooks' because, as he explains: 'As soon as the images are taken out of their original context and placed in a new one, they can produce interesting results. ${ }^{79}$ These two examples provide an intersection with Pound's practice, not only for the content they contain but in their methodology of collection and curation. Both Pound and Kessels purchase photographs second-

\footnotetext{
${ }^{76}$ Sontag, On Photography, 11.

${ }^{77}$ Batchen, "Snapshots," 123.

${ }^{78}$ KESSELSKRAMER, "IN ALMOST EVERY PICTURE 1," kesselskramerpublishing, N.d., http://www.kesselskramerpublishing.com/catalogue/inalmosteverypicture1/.

${ }^{79}$ KESSELSKRAMER, “USEFUL PHOTOGRAPHY 1,” kesselskramerpublishing, N.d., http://www.kesselskramerpublishing.com/catalogue/useful-photography-1/.
} 
hand, and arrange them by themes chosen, apparently arbitrarily, to emphasise the excessive nature of image production. With these two examples in mind, we can consider how Pound's and Kessels' practices differ. The mechanism of dissemination, for instance, limits Kessels to a book format and, therefore, a finite number of photographs - usually between 100 and 200. For Pound, however, the limitation on numbers is dependent on the size of the exhibition environment, which is why The Great Exhibition can display over 4000 photographs.

Another project of extreme scale undertaken by Kessels is 24 Hours in Photos (2011), a site-specific installation, which has been restaged at several venues [Fig. 33]. For this work, Kessels uses a computer algorithm to collect every image uploaded to the photo-sharing website, Flickr, in the space of 24 hours. ${ }^{80}$ Within the space of a day, Kessels had collected approximately 950,000 photographs. ${ }^{81} \mathrm{He}$ printed these photographs as $6 \times 4$ " prints to emphasise the volume and ubiquitous nature of snapshot culture. The installation emphasised the nature of our contemporary relationship to image production, which was able to be felt in the overwhelming presence of hundreds of thousands of material objects: 'Thanks to the wealth of image sharing sites and the availability of digital cameras, the world is subjected to an avalanche of new photos every single day. ${ }^{82}$ While this exercise may seem excessive, it can be contextualised further when we understand that the artist was only engaging with one image-sharing website in the space of 24 hours. Daniel Palmer describes Kessels' practice as 'turning photographic excess into rubbish' with 'no attempt to filter or sort. ${ }^{93}$

If we accept the conservative estimate that approximately 1.3 trillion photographs are taken annually, then the three million or so photographs currently listed for sale

\footnotetext{
${ }^{80}$ Erik Kessels, "24 Hrs in Photos," Kesselskramer, N.d., http://www.kesselskramer.com/exhibitions/24-hrs-of-photos.

${ }^{81}$ The Story Behind Erik Kessels' Obsession, How He Breathes New Life Into Amateur Photography, YouTube, 2017, https://www.youtube.com/watch?v=7_Yjf511G9k.

${ }^{82}$ Kessels, "24 Hrs in Photos."

${ }^{83}$ Palmer, Photography and Collaboration, 151.
} 
on eBay is comparatively miniscule. ${ }^{84}$ When compared to the number of digital images Kessels gathered in the space of a day in 2011, the number of online auctions for photography is relatively low. This burgeoning second-hand market for vernacular photographs is antithetical to their intended function:

In a few short years these photos have been set adrift ... Millions of these have found their way to eBay. Cut off from their reason for being, and from their takers and original owners, the images await new homes, new owners and new meanings. ${ }^{85}$

These photos are ordinary snapshots, which have all been sold on eBay. Some have been removed from family albums, while another is a press photograph of Charlie Sheen from the movie Three For The Road [Fig. 34]. Not only did the art world reject these photographs but so, too, did their original owners. For example, consider Pound's photograph of the man walking shirtless on the beach with the cigarette burn applied to his head [Fig. 32] - this image was taken, developed, printed, burnt, discarded, advertised for sale on eBay, sold online, sent to Melbourne and then placed in a vitrine beside other damaged photographs, to become part of The Great Exhibition at the NGV in 2017. This damaged photograph, which may have been someone else's Winter Garden at some point, is now part of a site-specific installation.

Situated against a black backdrop, the photographs in Damaged are positioned as if they still belong in a photo-album but are now part of Pound's photo-album. To emphasise this relationship, in some of Pound's installations the photographs are adhered to the wall with the archetypal photo-corners used in such albums [Fig. 35]. The idea of photo-albums as a categorisation tool is important here, as Pierre Bourdieu proposes that any album of family photographs imposes an order:

\footnotetext{
${ }^{84}$ Throughout the course of this research, I checked eBay's listings for photographs by selecting the pre-defined Category 'Collectables' and selecting 'Photographic Images.' I repeated this process several times and the number fluctuated but overall remained within $10 \%$ of this cited number.

${ }^{85}$ Finch, "A Conversation: Patrick Pound and Maggie Finch," 26.
} 
The family album expresses the essence of social memory. [...] The images of the past arranged in chronological order, the logical order of social memory, evoke and communicate the memory of events which deserve to be preserved because the group sees a factor of unification in the monuments of its past unity... ${ }^{86}$

Pound orders photographs into his own categories. Just as repetition inhabits the realm of snapshot photography and photo-albums, there is a specific set of conventions that typifies the display of photographs in contemporary practice. For example, Erik Kessels' book IN ALMOST EVERY PICTURE \#13 (2014) is 'a short history of photography's most common mistake: part of the photographer's hand appearing in frame' [Fig. 36] ${ }^{87}$ In each photograph a blurred appendage has strayed in front of the lens when the photograph was taken, as the photographer gazed obliviously through the viewfinder. Photographs exhibiting this common mistake are collected by both Kessels and Pound, the latter incorporating them into his series The hand of the photographer (2007-2017) in The Great Exhibition [Fig. 37]. The site-specific installation features numerous photographs with hands and fingers in front of the lens. Such mistakes are symptomatic of the amateur photographer and a signifier of snapshots that perhaps never made it to the photo album. They are, however, becoming increasingly uncommon, as digital technologies have enabled them to be deleted before they are printed or uploaded. ${ }^{88}$ For artists like Pound, the mistakes are 'like the punctum' and 'a particular result of photography's indiscriminate and contingent record of whatever is in front of the lens. ${ }^{89}$

The parallels between Kessels' IN ALMOST EVERY PICTURE \#13 and Pound's The hand of the photographer are apparent in their repeated trope. Separating these artists' practices, however, is the methodology of their collection and subsequent display. Kessels' collection of photographs was published as a book. Limited to 180 pages, it is, arguably, contained and finite whereas Pound's collection series are

\footnotetext{
${ }^{86}$ Bourdieu, 30-31.

${ }^{87}$ KESSELSKRAMER, “IN ALMOST EVERY PICTURE 13,” kesselskramerpublishing, N.D., http://kesselskramerpublishing.com/catalogue/in-almost-every-picture-13/.

${ }^{88}$ Daniel Palmer, "The Mistake in Photography: Patrick Pound, Jackson Eaton and the Paradoxical Self Image," Dissect 2 (2015): 17.

${ }^{89}$ Palmer, 22.
} 
continuous, expanding and contracting, with different photographs in each exhibition. We must also consider the context of their display. Pound's response to an 'avalanche of images' has resulted in his own methodology of trying to 'make perfect sense of [it]. ${ }^{90}$ Photographs shift and shuffle each time they are exhibited by Pound in a meticulous curatorial process, exemplified in The Great Exhibition. It is the careful selection of each photograph in response to the NGV collection items that is a synthesis of Pound's practice. Each site-specific installation is, in essence, a reaction to the institution hosting him.

Pound describes the process of selecting images as 'collaborative.' In the development of The Great Exhibition, Pound worked alongside Curator Maggie Finch and several specialist curators who were able to 'understand the way [Pound] was looking at things. ${ }^{91}$ The institution and its curators must, therefore, be considered as critical to the successful execution of The Great Exhibition. The role of the museum within Pound's practice becomes important, because: 'The museum temporarily stages things according to my new rules. I ask the objects and the images to do something else altogether. ${ }^{92}$ Just as photo-albums serve as a tool of unification and social memory, so do institutions like the NGV: 'Museums are also always telling us that their function is to tell stories. ${ }^{93}$ One of the risks with curating an exhibition around an established collection is that some of the narratives of the exhibition veil the works being shown. An example of such veiling can be seen with The car by John Brack, a painting that is symbolic of an Australian nationalist and modernist rhetoric and which I, even though a New Zealander, was aware of due to its canonical status [Fig. 17]. The challenge for Pound is to usurp the dominant narratives and transpose his own. The site-specific installation, Drive by (en passant) (2016-2017), overwhelms The car with its hundred or so photographs of passing cars. Often the seamlessness of the transition to and from the collection items is the point: 'I am always amused when visitors cannot tell my

\footnotetext{
${ }^{90}$ Finch, "A Conversation: Patrick Pound and Maggie Finch," 21.

${ }^{91}$ Finch, 15.

${ }^{92}$ Finch, 13.

${ }^{93}$ Finch, 12.
} 
things from the NGV's. ${ }^{94}$ This practice could be seen as an exercise of curatorial power; as the objects are displaced from their original contexts and given new frameworks to operate within.

One of the critical questions asked of The Great Exhibition is: 'What privileges Pound to be chosen [by the NGV] to undertake these juxtapositions/collages? ${ }^{95}$ In fact, and it must not be forgotten, the NGV was one half of the curatorial equation. Curatorial theorist Paul O’Neill states: 'Straddling the two camps, there remains a contradictory pull between artistic autonomy, on the one hand, and curatorial intervention on the other. ${ }^{96}$ I observed some of the limitations applied by the institution within The Great Exhibition. For instance, the site-specific installations of vernacular photographs in the first gallery were not mounted directly onto the wall using Blu Tack as they have been in previous site-specific series such as Documentary Intersect (2016) at the Adam Art Gallery. Instead, each installation Lamps (2016-2017), The readers (2016-2017), Listen to the music (2016-2017) and Photography and air (2016-2017) - is framed using homogeneous black matts and frames - as if to apply a constraint to an artist who thrives on constraints. Pound's response appears as a box of unfiled photographs sitting in one of the vitrines and representing all the untapped possibilities of what remains in his collection.

Hans Ulrich Obrist believes that an exhibition is 'an ongoing, expanding project that evolves over time. ${ }^{97}$ This is true of The Great Exhibition, which had several related exhibitions leading up to it, including The gallery of air staged at the NGV in 2013 and Documentary Intersect at the Adam Art Gallery in 2016. The gallery of air is one of Pound's site-specific installations based on the constraint of 'air.' Originally part of Pound's collection titled The museum of air, the installation transformed once it was moved within the context of the NGV. The collection of air

\footnotetext{
${ }^{94}$ Finch, "A Conversation: Patrick Pound and Maggie Finch," 13.

${ }^{95}$ Maizel, "Patrick Pound: The Great Exhibition," 50.

${ }^{96}$ Paul O'Neill, The Culture of Curating and the Curating of Culture(s) (Cambridge, MA: The MIT Press, 2012), 88.

${ }^{97}$ Cited in O'Neill, 117.
} 
photographs then became part of the installation Photography and air (2016-2017) in The Great Exhibition. As if breathing, Pound's collection expands and contracts with its different iterations.

Pound's Documentary Intersect was included in a group show at the Adam Art Gallery alongside Walker Evans' The Magazine Work, Sherrie Levine's African Masks After Walker Evans and Sonya Lacey's Newspaper for Vignelli. The curatorial decision to position Pound alongside Evans was made because Evans has significantly informed his work. As I have noted previously, Pound discusses Walker Evans and James Agee's Let us now Praise Famous Men in his doctoral thesis. As a result of this research, Pound began to collect in the same vein as Evans who, for instance, identified a postcard of Cliff House as exemplary of 'documentary style.'98

For Evans (much as for Walter Benjamin), the photograph petrifies the world in a significant fragment - a remnant. Those indexical records, those significant documents of the obsolete (the already petrified), can both show us things clinically, and can be put together tellingly. ${ }^{99}$

Evans collected objects such as the postcard of Cliff House in order 'to rescue these humble printed ephemera from neglect and from their fading quietly into oblivion.' ${ }^{100}$ He recognised their inherent value and documentary quality: 'It is time to atone for an unjust disdain for those little pasteboard views before they disappear.' ${ }^{101}$ An example of how much Evans valued photographic ephemera can be seen through the inclusion of his postcard of Cliff House in San Francisco in his article 'Come on Down' from Architectural Forum in 1962. Pound acknowledges Walker Evans with his series The Cliff House (2016-2017), which includes over 200 iterations of the Cliff House as postcards. ${ }^{102}$ Pound emulates Evans' fascination with the Cliff House in his collection of Cliff House postcards, arranged

\footnotetext{
${ }^{98}$ Patrick Pound, Documentary Intersect. (Wellington, NZ: Adam Art Gallery, 2016). 2.

${ }^{99}$ Pound, Documentary Intersect, 2.

${ }^{100}$ Ibid.

${ }^{101}$ Pound, 2.

${ }^{102}$ Ibid.
} 
chronologically like a scene from a movie, documenting the building through its numerous iterations, including being re-built four times. This series serves as a direct connection to Walker Evans' practices of documentation and collecting. While Evans did not foresee the voracity of the Internet as a site of convergence for this material, eBay has enabled Pound to collect with ease using specific criteria. After Pound purchased a single postcard of the Cliff House, the image mutated into a collecting constraint and became part of a new, active collecting strategy. With the typological constraint of a postcard of the Cliff House, the collection burgeoned into Documentary Intersect - a horizontal chronological sequence of the different iterations of Cliff House [Fig. 38]. This installation then transmuted in to The Cliff House (2016-2017) in The Great Exhibition, demonstrating what Ulrich Obrist would describe as the 'ongoing, expanding project' of curation. ${ }^{103}$ The exhibition becomes a means to sort and categorise the endless avalanche of images as well as his ideas.

\section{Our Archival Condition}

The concept of the archive informs the work of Pound but is not, however, easily defined. As Jacques Derrida emphasises: 'nothing is less clear today than the word 'archive." 104 Although an ambiguous term and evasive of any concrete definition, Derrida does provide an extensive psychoanalytical analysis of the archive in Archive Fever: A Freudian Impression (1995). Derrida contends that the condition of the archive balances between two conflicting urges: 'death drive and the pleasure principle, between Thanatos and Eros. ${ }^{105}$ The desire to collect is both a mechanism to preserve life in the form of archivisation (Eros) and to heed the destruction of life (Thanatos). The archive, therefore, functions as a site of preservation, ensuring that memories survive.

\footnotetext{
${ }^{103}$ O'Neill, The Culture of Curating and the Curating of Culture(s), 117.

${ }^{104}$ Jacques Derrida, “Archive Fever: A Freudian Impression," ed. Eric Prenowitz, Diacritics 25, no. 2 (1995): 57, https://doi.org/10.2307/465144.

${ }^{105}$ Derrida, 14.
} 
When we think about the archive as a means to ensure that memory survives, we think about photography. With companies like Kodak implicating photography in ideas about 'memory and loss,' it is no wonder that photography has become a mechanism to archive ourselves. ${ }^{106}$ Photography confirms both life and death. When we consider the 4,000 or so vernacular photographs included in The Great Exhibition, we see that many were taken to record a memory of the living. After all, photography 'is the medium of record.' ${ }^{107}$ In reality, however, many subjects of the photographs would have died by the time they were displayed in The Great Exhibition. This intrinsic relationship between photography and memory is reiterated by Pound, who calls his collection 'a memory machine.' ${ }^{108}$ It must be noted that Pound's memory machine is a constructed archive of other people's memories. In this context, we must consider how archives are constructed to construe meaning.

The archive is defined by what can be collected and is constructed in relation to the socio-political environment it is connected to. Institutional collecting is a form of archivisation by museums and libraries, which are actively collecting in response to their environment. While Jorge Luis Borges wrote about the concept of the infinite expanses of the archive in The Library of Babel (1941), this is far from the reality of the contemporary archive. With limited space and resources available, collection policies advocate for the acquisition of single representative examples, rather than allowing the amassing of duplicates. Pound's collection strategy stands at odds with institutional collecting; he chooses, instead, to collect the same item by repeatedly using his own typologies as a form of constraint.

Pound works in a similar fashion to German artist Joachim Schmid whose Archiv works provide a useful comparison to Pound's practice. Archiv comprises 721 different pieces made by Schmid between 1986 and 1999, each titled according to their chronological production - Archiv \#001 (1986) is the first in his series and

\footnotetext{
${ }^{106}$ Batchen, "Snapshots," 130.

${ }^{107}$ Finch, "A Conversation: Patrick Pound and Maggie Finch," 26.

${ }^{108}$ Pound, "The Gallery of Air."
} 
Archive \#721 (1999) the last. Each of the 721 works is mounted in a $40 \mathrm{~cm}$ by $50 \mathrm{~cm}$ frame, regardless of the number of photographs in each work. Archiv \#001 includes four postcards 'showing a rock named Venus's Birthplace on the shore at Paphos on Cyprus,' all equally spaced and centred inside the frame [Fig. 39]. ${ }^{109}$ This assemblage of commercially produced postcards, arranged according to their visual similarities, reminds us of Pound's series The Cliff House (2016-2017). Schmid 'knows the metaphorical implications of empty spaces' and he uses this throughout the Archiv series to great effect. ${ }^{110}$ For instance:

The larger number of the Archiv's pages carry an empty horizontal line, and the arrangements rarely form anything like a centre. The importance of this method can be read in reverse: When there is a central image and the number of images is uneven, then there is a meaning in the images themselves. ${ }^{111}$

Schmid's intent, through his use of space, is to 'invite[s] the viewer to compare them, but after a short examination one is left with no idea of what could be compared here. ${ }^{112}$ This echoes the way Pound's collections function when on display in The Great Exhibition; as if the viewer must solve the puzzle through an exercise of visual comparison. Once this exercise is done, the differences between the four postcards emerge - even though they are mass-produced.

Joachim Schmid calls the Archiv series 'an analytical survey of international vernacular photography' designed to 'highlight the mechanical uniformity and conformity of image production, the collective patterns and rituals of popular photographic representations.' ${ }^{, 13}$ Much like Pound, Schmid is highlighting the archival nature of photographic production that is contributing to a wider

\footnotetext{
${ }^{109}$ Rolf Sachsse, "Joachim Schmid's Archiv," Geoffrey Batchen, ed., History of Photography 24, no. 3 (2000): 256.

${ }^{110}$ Sachsse, 256.

${ }^{111}$ Ibid.

112 Ibid.

${ }^{113}$ Joachim Schmid, “Archiv (1986-1999) - Joachim Schmid,” accessed July 3, 2018, http://www.lumpenfotografie.de/2006/01/01/archiv-1986-1999/.
} 
'collective memory.' 114 The sameness of each vernacular photograph is made salient through the act of placing them together in succinct categories. Schmid considers the use of archives as a sorting mechanism:

One of the best ways to observe collective production of meaning is the system of indexing and classifying photographs. In a traditional picture library photographs are classified by subject. An archive is made accessible by applying a limited number of keywords following a strictly determined system of classification... It is significant that no such overarching and predetermined system exists in usergenerated online pools. ${ }^{115}$

Pound, too, writes about the 'satisfaction to be had sorting pieces' as a way of sorting thoughts. ${ }^{116}$ Schmid and Pound both employ the act of categorisation as a significant component of their practice. We know that this is not an exclusive phenomenon but part of a wider societal function to produce meaning through the use of photographic archives.

Archives signify the preservation of memory and thus contribute to a wider collective memory within society. Collating material 'on which to project memories' is 'part of [Schmid's] oeuvre.' ${ }^{117}$ Archiv (1986-1999) is just one series of Schmid's that revolves around the enduring theme that 'the everyday use of photography is forming individual and collective memories. ${ }^{118}$ Again, photographs function as material markers of these memories. The archives that artists like Schmid and Pound form through their collecting demonstrate how photographs evoke these memories. Pound's Damaged series, for example, shows how the memories that permeate photographs can lead to their very defilement. When entering The Great Exhibition, the viewer is confronted by hundreds of photographs that include some trace of a person's shadow in the site-specific installation The

\footnotetext{
114 Joachim Schmid, "Reload Currywurst,” ed. Joan Fontcuberta (¿Soñarán los androides con cámaras fotográficas? Do androids dream of cameras?, Madrid, Spain: Ministerio de Cultura, 2008), 293.

${ }^{115}$ Schmid, 295.

${ }^{116}$ Pound, "The Gallery of Air."

117 Sachsse, "Joachim Schmid's Archiv," 256.

${ }^{118}$ Sachsse, 255.
} 
photographer's shadow (2000-2017) [Fig. 27]. It is evident that the viewers are projecting their own memories onto the photographs as they attempt to solve Pound's puzzle. I observed two women, marvelling at the excess, begin isolating details from the images. One of the pair began talking about a car in one of the photographs, recalling the 'same one' from her childhood as she attempted to date the era in which the photograph was taken. As she recalls her memories, a function of vernacular photography is fulfilled.

Curator Okwui Enwezor has written extensively on the concept of the archive. He proposes that photography encourages our own archival inclination ' $[\mathrm{b}]$ ecause the camera is literally an archiving machine, every photograph, every film is a priori an archival object.' ${ }^{119}$ The nostalgic sentimentalism enveloping snapshot photography 'exemplifies the most prominent aspect of the private motivations for image making, for it not only records that burning desire for the archival, it also wields a formidable ethnographic meaning.' The woman connecting to the car she remembers from her childhood elicits nostalgia and confirms an important reason for taking photographs - to capture a moment in time, in order to remember it one day:

The proliferation of the snapshot, of domestic photographic production, clarifies this process. However, we know that in this guise of image production-its crudest, most sentimental form - the making of a photograph is part of a constant construction of aide-mémoires, a gigantic machine of time travel, as much teleological as technological. ${ }^{120}$

Again, it is death that haunts the motivation and production of the photographic archive. Photographic albums function as repositories for these memories, to be called upon as aide-mémoires whenever needed. Museums, too, have come to occupy this function as a site of collective memory.

${ }^{119}$ Okwui Enwezor and International Center of Photography, eds., Archive Fever: Uses of the Document in Contemporary Art / Okwui Enwezor (Göttingen; London; Steidl: Thames \& Hudson, 2008), 12.

${ }^{120}$ Enwezor and International Center of Photography, 13. 
Marcel Duchamp's conceptualisation of the archive is a useful tool with which to consider Patrick Pound's collection and The Great Exhibition. Pound says that Duchamp's The bride stripped bare by her bachelors, even (The green box) (1934, Metropolitan Museum of Art, New York) is 'key' to his curatorial inspiration [Fig. 40]. ${ }^{121}$ The green box is a collection of 93 notes and photographs contained within a box that details Duchamp's process when making The bride stripped bare by her bachelors, even (The Large Glass) (1915-1923: Philadelphia Museum of Art, Philadelphia) [Fig. 41]. Duchamp notes that The green box 'is in fact a box containing photographic reproductions of notes written by hand and photos of pictures. ${ }^{122}$ The green box functions like an archive but with no discernible order; the viewer is left to interpret and arrange the information themselves. The work then is also about the very nature of 'reproduction and undermining the relationship between the original and copy.' ${ }^{123}$ It is also ironic that Duchamp used the term 'the snapshot effect' to describe the readymade in relation to their 'tremendous arbitrariness with regard to meaning. ${ }^{, 124}$

Duchamp's The green box is linked to his Boitte-en-valise (1935-1940), which he describes as 'a portable museum' consisting of a box containing reproductions of his own works - such as a miniature Fountain (Fountaine) [Fig. 42]. Benjamin Buchloh describes how Boîte-en-valise is critical to this discussion:

All of the functions of the museum, the social institution that transforms the primary language of art into the secondary language of culture, are minutely contained in Duchamp's case: the valorisation of the object, the extraction from context and function, the preservation from decay and the dissemination of its abstracted meaning. ... [With it Duchamp] also changes the role of the artist as creator to that of the collector and conservator, who is concerned with the placement and transport, the evaluation and institutionalization, the display and the maintenance of a work of art. ${ }^{125}$

\footnotetext{
${ }^{121}$ Finch, "A Conversation: Patrick Pound and Maggie Finch," 23.

${ }^{122}$ Marcel Duchamp cited in Filipovic, The Apparently Marginal Activities of Marcel Duchamp, 56.

${ }^{123}$ Filipovic, 60.

${ }^{124}$ Krauss, "Notes on the Index: Part 1," 205-6.

${ }^{125}$ Benjamin H. D. Buchloh cited in Filipovic, The Apparently Marginal Activities of Marcel Duchamp, 131.
} 
The Boîte-en-valise exposes the museum's ability to decontextulise, which Duchamp controls by containing his work within a box in his own exhibition space. It is here that I would like to turn my attention to Pound's work The game of things (2016) [Fig. 43], which is situated in the hallway connecting The Museum of there / Not there and The collection shelves. The game of things is a series of eight black Solander boxes. Within each box is a pairing of a photograph and an object. Pound has written a tiny explanation on the label: 'Photographs and things reflect on each other as if in a game or a puzzle.' ${ }^{126}$ In one of the boxes is a snapshot of a theme park ride, like a rollercoaster, positioned opposite a perfect tower of Cuisenaire rods [Fig. 44]. Together, the two visually operate as a reflection of each other despite their disparate subject matter. The game of things is reminiscent of Duchamp's Boîte-en-valise works. While seemingly simple, the mirroring of the objects presents us with a literal snapshot of Pound's methodological process. It is about vernacular photography, collecting and art history.

${ }^{126}$ Finch, "The Great Exhibition Artwork Labels," 283. 


\section{Chapter Three: Algorithms}

\section{'The value of an idea is proved by its power to organize the subject matter'1 Goethe}

So far, within this thesis, I have interrogated two major components of Patrick Pound's practice: the destabilisation of authorship and the integral role that vernacular photography has in defining his practice. The previous chapter discusses the role the archive plays in the practices of artists such as Joachim Schmid and compares these to the archives of collecting institutions such as the NGV. By integrating his collection into the NGV, Pound operates as an artist-as-curator for The Great Exhibition. In this chapter I consider the evolution of the term, 'artist-ascurator,' in the context of Fred Wilson's Mining the Museum and Edward Steichen's The Family of Man, in relation to The Great Exhibition.

This chapter explores another key component of Pound's practice: his use of eBay as an algorithmic tool to collect and organise the collections he deploys in his works. In order to better understand the eBay algorithm, I mimic and then analyse Pound's procurement process. His use of algorithmic processes can be linked to Georges Perec and the OuLiPo, whose conceptual writing processes incorporated automation. Mark Wolff discusses how Perec's practice can be compared to early computing but is actually closer to the 'oracle' machine conceptualised by Alan Turing. The algorithmic logic behind Perec's practice can be seen throughout Pound's own practice and The Great Exhibition. It is exemplified in Thoughts-ofsorts, the computer sorting machine in The Great Exhibition, as well as the gallery of matrixes and intersections.

\footnotetext{
${ }^{1}$ Cited in Brian O'Doherty, Inside the White Cube: The Ideology of the Gallery Space [1976] (Berkeley, Los Angeles: California: University of California Press, 1999), 87.
} 
I explore the historical precedent set by Robert Rauschenberg in his 'Random Order' manifesto written in 1962. Rauschenberg's works all incorporate ideas about the archive of amateur photographs, sorting and categories, intersections and display. Rosalind Krauss's 'Perpetual Inventory' (1999) analyses Rauschenberg's work, allowing us to relate this to Pound's practice.

\section{'Artist-as-curator'}

The work of conceptual artist Fred Wilson is often cited as an example of the critical intersection between artistic practice and museum collections. Of note is his landmark exhibition, Mining the Museum (3 April 1992 - 28 February 1993), which was staged at the Maryland Historical Society in Baltimore. The exhibition aimed to show 'the museum's collection in a new, critical light,' by allowing Wilson to represent objects as he chose within the museum. ${ }^{2}$ This methodology is analogous to that of Pound: 'Wilson appropriated the museum's collection and reshuffled it so that it communicated a different message, almost antithetical to that of the original constellation.' ${ }^{3}$ Mining the Museum interrogated the standard, dominating narratives on display that were commonplace in museums like the Maryland Historical Society which 'tended to present this history from a specific viewpoint' and that was the view of its white founders. ${ }^{45}$ In one of the arrangements, Wilson positions three empty pedestals labelled with the names of Benjamin Banneker, Harriet Tubman and Frederick Douglass across from three pedestals bearing the busts of Henry Clay, Napoleon Bonaparte and Andrew Jackson [Fig. 45]. ${ }^{6}$ A trophy engraved with the word 'Truth' divides the two sets of pedestals, emphasising the stark juxtaposition between the absence of important African-American figures in local history and the presence of three white men who had never lived in

\footnotetext{
${ }^{2}$ Elisabeth Ginsberg, "Mining the Museum," in Beautiful Trouble: A Toolbox for Revolution, ed. Boyd Andrew and Mitchell D. Oswald (New York, NY: London, UK: OR Books, 2012), 334.

${ }^{3}$ Ginsberg, 336.

${ }^{4}$ Ginsberg, 334.

${ }^{5}$ Ibid.

${ }^{6}$ Howard Halle and Fred Wilson, "Mining the Museum," Grand Street, 1993, 153.
} 
Maryland. ${ }^{7}$ As Geoffrey Batchen notes: 'the shifting of an object from one place to another allowed for a juxtaposition that transformed the meaning of the entire display. ${ }^{8}$ Wilson's curatorial intervention demonstrated that black histories have been systematically excluded from the museum through its strategies of collection and display.

It is here that I wish to note the relationship between Wilson's exhibition and Pound's site-specific installation The Museum of There / Not there (2016-2017), which displays the majority of items he has used from the NGV's collection. Both Wilson and Pound exploit the idea of presence and absence within their curatorial arrangements. Pound's The Museum of There / Not there is the 'biggest new collection work' that aims to 'hold and express an idea of making the absent present. ${ }^{9}$ The installation consumes an entire gallery; within it, eight cabinets and a sizable octagonal plinth occupy the centre of the room [Fig. 46 and Fig. 47]. The Museum of There / Not there is arranged into thematic displays around the room, which are either confined by a cabinet or by their grouping on the wall. One of these groupings, titled 'placement and displacement,' includes David Moore's Migrants arriving in Sydney (1966) and Alfred Stieglitz's The steerage (1907/1911), which I discussed in the first chapter. To the side of the seven images hung in formation are the engraving Music of the Natives of New South Wales (Musique des sauvages de la Nouvelle-Galles du Sud) (1824) [Fig. 48] and the etching Bennelong (after 1798) [Fig. 49], which operate as a pair and are 'displaced' from the other seven. Underneath the profile of the Aboriginal man in Bennelong, the text states: 'Portrait of Bennilong; a native of New Holland, who after experiencing for two years the Luxuries of England, returned to his own Country and resumed his Savage Habits. ${ }^{10}$ To contextualise this etching further, while Bennelong was in England he became an object of typological investigation

\footnotetext{
${ }^{7}$ Ginsberg, "Mining the Museum," 334-35.

${ }^{8}$ Batchen, "Keepers: Patrick Pound and the Art of Collecting," 36.

${ }^{9}$ Finch, "A Conversation: Patrick Pound and Maggie Finch," 11.

${ }^{10}$ Transcription cited here National Gallery of Victoria, "Bennelong," Collection Online, N.d., http://www.ngv.vic.gov.au/explore/collection/work/89916/.
} 
by Johann Friedrich Blumenbach, who had hoped to 'chart the nature and extent of human variation' using 'Indigenous Australian skulls.' ${ }^{11}$ Pound writes that the etching was included because it is contentious: 'Because this is so galling to us, we can at least assume we have come some little way. I think this page also reminds us that we have a dreadful past and a long way to go. ${ }^{12}$ The physical placement of the pairing away from the other seven works alludes to a narrative of displacement from colonisation. We know that Yemmerrawanne also travelled to England and sang alongside Bennelong but he is absent and the Music of the Natives of New South Wales stands in his place. Presence and absence, placement and displacement - these aspects of the human condition are interrogated by Pound through his careful curatorial constructions in The Museum of There / Not there.

There are also, however, examples of satirical curatorial assemblages in The Museum of There / Not there. The section titled 'there not there (close shaves)' includes John Brack's Self-portrait (1955), David Potts's Cat show, London (1953), Jules Lefebvre's The grasshopper (La Cigale) (1872) and Hendrick Goltzius's The Circumcision (1594) [Fig. 50]. The sign, 'Best Neuter,' in Pott's Cat show, London automatically forms an ironic affiliation with Goltzius's The Circumcision. Brack's Self-portrait depicts a man in a bathroom facing us and holding a razor up to his cleanly shaven face, connoting the act of shaving. As your eyes slip to the right of Brack, Lefebvre's life-sized painting The grasshopper (La Cigale) abruptly punctures the ensemble. The female nude, an allegorical representation of improvidence, too, is cleanly shaven. The puzzle is easily solved and the viewer (including gallery attendants) either quickly moves on or lingers a little longer gazing into a perfectly shaven abyss. Fred Wilson also deployed 'various satirical techniques, first and foremost irony' in Mining the Museum. ${ }^{13}$ The practices of Patrick Pound may be compared with those employed by Wilson, but it is Pound

\footnotetext{
${ }^{11}$ Paul Turnbull, Science, Museums and Collecting the Indigenous Dead in Colonial Australia, Palgrave Studies in Pacific History (Cham, Switzerland: Springer International Publishing, 2017), 62, https://doi.org/10.1007/978-3-319-51874-9_14.

${ }^{12}$ Finch, "A Conversation: Patrick Pound and Maggie Finch," 15.

${ }^{13}$ Ginsberg, "Mining the Museum," 334.
} 
who labels himself as 'at the Kath and Kim end of post-studio postconceptualism. ${ }^{14}$

The development of The Great Exhibition required the support of the NGV's specialist curators in order to find items in the collection relevant to Pound's categories:

Searching through the racks with Laurie there were surprises that I would never have found via the Gallery's online resources, such as a very fragile work wrapped in tissue to keep the paint together prior to restoration, or empty frames that fit directly in my 'There / Not there' category. ${ }^{15}$

In other words, Laurie Benson, Curator of International Art, was able to make the invisible visible by physically finding works that were absent from the online catalogue, perhaps due to their inadequate metadata or intentional exclusion by the NGV. This example of curatorial collaboration does serve to exemplify the collision between Pound's methodology of categorisation and that of the NGV.

While Pound could be said to be 'mining' the museum, as Fred Wilson had in 1992, his process relied on the curators partnering with him in this 'mining': 'They all seemed to understand very well the way I was looking at things. ${ }^{16}$ Ironically, Pound's curatorial process could be considered a form of 'institutional critique' that builds on a 'burgeoning phenomenon of the artist-curator.' ${ }^{17}$ According to Paul O'Neill, the term 'artist-curator' can be traced to the 1960s and refers to a trend of artists curating exhibitions. ${ }^{18}$ O'Neill observes that the term 'artist-curator' has evolved to mean: '.. practitioners using exhibition design, architectural structures, and curatorial strategies as a way of presenting themselves, alongside other artists, to create composite public outcomes. ${ }^{, 19}$ Elena Filipovic, however, attests that the

\footnotetext{
${ }^{14}$ Finch, "A Conversation: Patrick Pound and Maggie Finch," 21.

${ }^{15}$ Finch, 13.

${ }^{16}$ Finch, 15.

${ }^{17}$ O'Neill, The Culture of Curating and the Curating of Culture(s), 105.

${ }^{18}$ Ibid.

${ }^{19}$ Gavin Wade in ibid.
} 
'artist as curator' was more likely to have been ushered in with the advent of the 'readymade' by Marcel Duchamp; she notes that the practice marked a 'junction' of change from 'production-orientated society to a selection-orientated society. ${ }^{, 20} \mathrm{We}$ can situate Pound within this trajectory. As Maggie Finch, co-curator of The Great Exhibition, highlights: '[Pound's] exhibition provides a unique context for us to view things anew and in so doing think critically about the role and strategies of galleries and museums. ${ }^{21}$ Pound is an artist who disrupts the normative paradigm of the 'exhibition narrative. ${ }^{22}$ While his practice situates Pound as an artist-ascurator, he is wary of the title 'curator' with reference to The Great Exhibition:

I don't speak of it as curating, but it is part of the 'curatorial turn', if you will. I realise my use of the term is rather selective here, and that might even be considered a curatorial decision, but I do not think of what I do as curating proper. I don't make most of this stuff - I only put it together. Okay, it's quasi-curatorial... I give in. ${ }^{23}$

The development of the artist-as-curator may be considered a satirical critique of the art institution. As Filipovic observes: 'exhibition walls were not only the ground for display, literally, but also the ground for authority, metaphorically. ${ }^{24}$ From the Paris Salon to the Great Exhibition (1851) or today's national museums like Te Papa Tongarewa, galleries are ritualistic sites functioning to affirm art through the contexts in which they are shown. It is for this reason that: 'The act of curating is implicated in what Pierre Bourdieu calls the "cultural production of the value of the artist and of art," in that exhibitions are more than public manifestations of subjective opinions. ${ }^{, 25}$ Pound's subversion of this function of authority of the institution is exemplified in his display of 4,000 vernacular photographs purchased from eBay and shown in the NGV alongside the masterpieces from its collection. Vernacular photographs, like the one of the man with a cigarette burn on his face in Damaged (2008-2017) [Fig. 32], bought online, are in an exhibition alongside

\footnotetext{
${ }^{20}$ Filipovic, The Apparently Marginal Activities of Marcel Duchamp, 154.

${ }^{21}$ Finch, "Introduction," 6.

${ }^{22}$ Ibid.

${ }^{23}$ Finch, "A Conversation: Patrick Pound and Maggie Finch," 16.

${ }^{24}$ Filipovic, The Apparently Marginal Activities of Marcel Duchamp, 91.

${ }^{25}$ O'Neill, The Culture of Curating and the Curating of Culture(s), 87.
} 
works by Eugène Atget, Walker Evans, David Hockney, Man Ray, Dorothea Lange and Henri Matisse and more. This incongruous elevation of the vernacular (or demotion of the collection) is intentional and satirical. The authority of the gallery and its space is punctured by Pound's rules and hierarchies.

One of Pound's site-specific installations of his collection of vernacular photographs, titled Look alike people (curators and others) (2007-17), further adds to his overarching insider joke. It is constructed with the studious viewer in mind, those who are familiar with exhibition and curatorial history, and not the average spectator. Pound makes connections and jokes throughout The Great Exhibition but they are only able to be enjoyed if the viewer has the knowledge. An example of this is the inclusion of a 1975 issue of Off Road magazine with the headline 'Walker Evans builds a Chevy Pickup!' in an installation titled The names (2007), in an apparent reference to the great photographer [Fig. 51]. Veiled references like these let curators know they are the subject of his elaborate joke. As Robert Leonard wrote:

As a curator, I couldn't help but ponder the way the show addressed my own vocation and its distorting effects. I felt pangs of pleasure and of guilt as Pound foregrounded the curatorial bag of tricks, flaunting the ways my colleagues and I place things into contrived contexts, fetishising some properties while forcing others to take a back seat, making things dance to our own tune. While artists legitimately fear being subsumed by wilful curators who have minds and projects of their own, Pound has turned the tables, making 'the curator' a trope for his art. ${ }^{26}$

Leonard's observations summarise the tone of The Great Exhibition. The very title of it connects to histories of display and tropes of curation, underscoring the view of Bruce Ferguson that: 'exhibitions are always rhetorical, ideological media, regardless of their particular form' and are merely part of a wider 'political economy of cultural production. ${ }^{27}$ Ironically, these curatorial and exhibition references remain invisible to those without the cultural capital to interpret them.

\footnotetext{
${ }^{26}$ Robert Leonard, "Enchanted Hunter," robertleonard.com, May 21, 2017, http://robertleonard.org/2017/05/enchanted-hunter/.

${ }^{27} \mathrm{O}$ 'Neill, The Culture of Curating and the Curating of Culture(S), 90.
} 
Another important historical exhibition that established a new paradigm in curatorial collaboration was The Family of Man (TFOM), staged at the Museum of Modern Art in New York (24 January 1955 - 8 May 1955). Edward Steichen was the Director of Photography at MoMA at the time and curated this exhibition, which represented a significant shift in how photography was curated and exhibited. TFOM could essentially be categorised as a globally crowd-sourced exhibition as Steichen received over two million photographs submitted 'from every corner of the earth. ${ }^{, 28}$ Steichen 'screened' the photographs down to a more manageable ten thousand and then arduously pared them again to the final 503 photographs, from 68 countries by 273 different photographers. ${ }^{29}$ TFOM's success as an exhibition can be measured by the ten million visitors it attracted as it toured globally and its permanent, albeit altered, display at Clervaux Castle in Luxembourg since 1994. ${ }^{30}$ MoMA describes TFOM as a 'photo essay celebrating the universal aspects of the human experience.' ${ }^{31}$ The exhibition's eventual enshrinement into UNESCO's Memory of the World Register came about because it is 'regarded as the memory of an entire era.' 32

Exhibition curation, however, is not an ideologically neutral practice and TFOM is an example of this. Curatorial decisions were made to promote a broader ideological purpose: as an expression of universal humanism during the Cold War. The exhibition was designed so visitors were guided through themed groupings of photographs matched with fragments of text from literary works. The groupings

\footnotetext{
${ }^{28}$ Edward Steichen, "Introduction," [1955] in Public Photographic Spaces: Exhibitions of Propaganda, from Pressa to The Family of Man, 1928-55, ed. Jorge Ribalta (Barcelona, Spain: Museu d'Art Contemporani de Barcelona, 2009), 433.

${ }^{29}$ Steichen, 433.

${ }^{30}$ Ministère de l'Economie, "The Family of Man," The Family of Man, N.d., https://www.visitluxembourg.com/en/place/museum/the-family-of-man.

${ }^{31}$ The Museum of Modern Art, "The Family of Man | MoMA," The Family of Man, accessed July 30, 2018, https://www.moma.org/calendar/exhibitions/2429.

${ }^{32}$ United Nations Educational, Scientific and Cultural Organization, "The Family of Man," Memory of the World, 2003, http://www.unesco.org/new/en/communication-andinformation/memory-of-the-world/register/full-list-of-registered-heritage/registered-heritagepage-3/family-of-man/.
} 
followed a narrative structure: lovers, marriage, pregnancy, childbirth, children, family groups, land, work, play, food, relationships, death, religion, aspirations, famine, inhumanities, revolt, teens, voting, faces, government [abridged]. ${ }^{33}$ Steichen invited people to 'believe in this relatedness. ${ }^{34}$ His methodology for 'depicting this 'essential oneness' is to place in juxtaposition photographs from all parts of the world. ${ }^{35}$ If, as Pierre Bourdieu asserts, photographic albums function to unify the family unit and create cohesion within the group, so too do exhibitions laid out like a family album - and this is reflected in the title 'The Family of Man. ${ }^{36}$ The exhibition was conceived as an international touring show from the outset, with several replicas shown simultaneously and funded by the United States Government. The idealistic Cold-War propaganda sought to unify 'the family of man' and was conceived of as 'a part of the cultural diplomacy objectives.' 37

TFOM is a visually overwhelming exhibition, which includes a 'combination of architectural and photographic elements' that 'constituted a new medium. ${ }^{38}$ With hundreds of photographic reproductions of various sizes displayed alongside overarching narrative captions, the exhibition was considered to be a "new photographic genre ... which fuses science, photography, architecture, layout and writing into a compelling synthesis' [Fig. 52]. ${ }^{39}$ This methodology of curation is relevant to this thesis not only because it involves such an immense display of photography but also because Pound utilises some of the same tropes of display in The Great Exhibition [Fig. 53]. These similarities, I believe, are a homage to TFOM and a broader history of photographic curation.

\footnotetext{
${ }^{33}$ The Museum of Modern Art, "The Family of Man Master Checklist," Master Checklist, 1955, https://www.moma.org/documents/moma_master-checklist_325962.pdf.

${ }^{34}$ Hilton Kramer, "Exhibiting The Family of Man," [1955] in Public Photographic Spaces:

Exhibitions of Propaganda, from Pressa to The Family of Man, 1928-55, ed. Jorge Ribalta

(Barcelona, Spain: Museu d'Art Contemporani de Barcelona, 2009), 442.

${ }^{35}$ Hilton Kramer, "Exhibiting The Family of Man," 440.

${ }^{36}$ Bourdieu, 30.

${ }^{37}$ Eric Sandeen, "The Show You See With Your Heart. The Family of Man on Tour in the Cold War World.," [2004] in Public Photographic Spaces, 471.

${ }^{38}$ Barbara Morgan cited in Fred Turner, "The Family of Man and the Politics of Attention in Cold War America," Public Culture 24, no. 1 (2012): 82.

${ }^{39}$ Ibid.
} 
Pound sources his vernacular photography globally, echoing Edward Steichen's international call for source material. Like TFOM, The Great Exhibition's photographs are not attributed to individual authors and do not have titles unless they are from the NGV's collection. In both exhibitions, photographs are presented in groupings pertaining to a certain theme - such as 'work' in TFOM or The photographer's shadow (2000-2017) in The Great Exhibition. A mirror was placed within TFOM as a point of reflection although later removed by Steichen because it was 'corny. ${ }^{40}$ Like Steichen, Pound has installed a mirror in the first gallery in The Great Exhibition, so that viewers of one of the first site-specific installations, The photographer's shadow, can see their reflections [Fig. 54]. Another salient connection between the two exhibitions is Pound's inclusion of a film transparency in the collection, The body in pieces (2010-2017). As the only transparency in The Great Exhibition, it mirrors Steichen's inclusion of the large colour transparency of an atomic bomb - the only colour image in TFOM.

Despite these congruencies between TFOM and The Great Exhibition, I am not arguing that Pound is making an overarching statement about American imperialism in his survey exhibition. Nevertheless, I do believe that these references are intentional. They are included for those viewers who are aware of TFOM, an exhibition that is considered to define the collective memory of an entire era. These references are the 'Easter eggs' of The Great Exhibition. ${ }^{41}$ They serve to remind us again that, as Pound reiterates, 'photographs and things reflect on each other as if in a game or a puzzle. ${ }^{42}$

\footnotetext{
${ }^{40}$ Turner, "The Family of Man and the Politics of Attention in Cold War America," 80.

${ }^{41}$ The term 'Easter eggs' emerges from videogame culture in the 1970s. It describes hidden features or inside jokes intentionally included in media like computer programmes, video games, movies or artworks. It emerges from the idea of Easter egg hunts, whereby you have to find secret 'Easter egg' within a game.

${ }^{42}$ Finch, Patrick Pound: The Great Exhibition, 108.
} 


\section{C'est eBay}

A consequence of the advent of online retail is that we can buy almost anything from the comfort of our own homes. From books to clothes, and even illicit drugs from the 'dark web,' international shopping has never been so easy. Pound writes that: 'My collections of photographic documents of all kinds would not be possible without the internet. ${ }^{43}$ Pound's praxis largely revolves around using the online auction website eBay to source his collections. ${ }^{44} \mathrm{He}$ observes that "eBay saw the unhinged photo albums of the world unite into one endlessly moving amateur photo feast' and it was the 'world-wide-web that allowed me to search for, and locate, so many exacting images with (relative) ease. ${ }^{45}$ Since it was officially launched in 1997, eBay has grown considerably. With the company's convergence with global shipping in 2012 and purchase of PayPal payment system in 2002, eBay became easier to access by those living outside of the countries eBay had traditionally operated within. ${ }^{46}$ No longer did Pound have to scour second-hand shops around his Melbourne home as he now had access to over one billion auctions on the eBay website at any one time. The chances of finding those 'exacting images' were increasingly probable.

Geoffrey Batchen has noted that the probability of finding items on eBay is not left to chance, as its site includes a powerful search engine: '[b]ased on what mathematicians call a Markov chain, this algorithm produces a probability distribution of the available products in eBay's database. ${ }^{47}$ This chain predicts what eBay users will purchase based on their previous purchasing patterns, or what Batchen refers to as 'taste profiles. ${ }^{48}$ In 2017, eBay introduced a new feature that allowed users to search based on images rather than words. The eBay software is

\footnotetext{
${ }^{43}$ Pound, Documentary Intersect, 1.

${ }^{44}$ eBay is accessed via the hyperlink www.ebay.com and requires a user account to operate.

${ }^{45}$ Pound, Documentary Intersect, 1.

${ }^{46}$ eBay Incorporated, "Our History - EBay Inc.," Our History, N.d., https://www.ebayinc.com/our-company/our-history/.

${ }^{47}$ Batchen, "Keepers: Patrick Pound and the Art of Collecting," 43.

${ }^{48}$ Ibid.
} 
based on Google Image's 'reverse image search' function, which allows the user to search by an image they have uploaded or one that is already online. ${ }^{49}$ The function suggests visually similar items to purchase on eBay based entirely on a reverse image search. Much like Pound, algorithms seek visually similar appearances in order to make connections and encourage consumption.

The market for vernacular photographs is perhaps best estimated by the approximately three million listings on eBay at any one time. ${ }^{50}$ In addition to these photographs, there are around 11 million 'collectable postcards' also for sale. ${ }^{51}$ One particular collection, which is cited by Batchen as emphasising the scale of Pound's collecting, is The Cliff House (2016-2017) collection of postcards:

First he entered a word or group of words ('Cliff House postcard') into eBay's search engine, and then he looked at whatever item came up for sale under that classification. Pound's process therefore begins from a potent, if sometimes awkward, interaction of word and image. ${ }^{52}$

Spurred on by Walker Evans's interest in the Cliff House postcard as an example of a 'lyrical document' from the twentieth century, Pound's collection ballooned from a single postcard to over 200 [Fig. 55]. ${ }^{53}$ Pound observes: 'When I exhibit The Cliff House I arrange the postcards sequentially in a very long line with each view getting closer and closer to the building, and then something surprising happens. It catches fire. ${ }^{54}$ The Cliff House collection is demonstrative of Pound's reconstructed narrative, which, in turn, is dictated by the variants of the Cliff House postcard's availability on eBay.

When The Cliff House series was displayed in The Great Exhibition, it was hung in a horizontal sequence that was carefully punctuated by another vertical sequence

\footnotetext{
${ }^{49}$ Accessible feature on www.images.google.com

${ }^{50}$ As I noted in my methodology in Chapter Two, n84

${ }^{51}$ Accurate estimate as of 15 July 2018.

${ }^{52}$ Batchen, "Keepers: Patrick Pound and the Art of Collecting," 43.

${ }^{53}$ Pound, Documentary Intersect, 2.

${ }^{54}$ Ibid.
} 
The sleepers (2007-2017). At the intersection between the two sequences is a gelatin silver photograph of a woman lying face down on the beach in front of Cliff House, in San Francisco, California [Fig. 56]. The vertical sequence continues upwards and downwards from this intersection, with vernacular photographs of people sleeping or sunbathing. It is here that I am reminded of Brian O'Doherty when he wrote: 'Life is horizontal, just one thing after another, a conveyer belt shuffling us toward the horizon. But history [...] is different. ${ }^{55} \mathrm{O}^{\prime}$ Doherty was writing here about the ideologies of gallery space in a series of essays published in Artforum magazine in 1976. He also discusses the spatial politics of hanging an exhibition: 'The esthetics of hanging evolves according to its own habits, which become conventions, which become laws. ${ }^{56}$ These 'laws' are then 'read' by spectators almost unconsciously. ${ }^{57}$ Pound's intersections on the gallery walls present viewers with a disruption to the 'conveyer belt' moving around the room. We are forced to stop, look up the vertical intersection and back down, sometimes having to physically retrace our steps to see another intersection - this time in the vertical thread. This arrangement could be considered somewhat analogous to the Salon exhibitions at the Musée du Louvre, where the walls were covered from the floor to the ceiling with artworks or, as O'Doherty describes them, a 'horrid concatenation of periods and styles. ${ }^{58}$

The original Great Exhibition (1851) was, of course, as its full title suggests, a culmination 'of the Works of Industry of All Nations' on display. With over 100,000 objects coming from 15,000 unique sources, the Great Exhibition was truly an aggregation of capitalist fetishism. ${ }^{59}$ The Crystal Palace was built especially to house all these objects, and occupied approximately 24 acres in Hyde Park. ${ }^{60}$ With over six million visitors to the Great Exhibition, the appetite for the commodity was

\footnotetext{
${ }^{55}$ O'Doherty, Inside the White Cube: The Ideology of the Gallery Space, 13.

${ }^{56}$ O'Doherty, 27.

${ }^{57}$ O'Doherty, 29.

${ }^{58}$ O'Doherty, 16.

${ }^{59}$ Liza Picard, "The Great Exhibition,” The British Library, 2009, https://www.bl.uk/victorianbritain/articles/the-great-exhibition.

${ }^{60}$ Ibid.
} 
clearly insatiable. ${ }^{61}$ We can compare this exhibition of goods to eBay and its position within the system of global trade. With over one billion items for sale and millions of vendors shipping globally, eBay exists as a contemporary aggregation of commodities - the only difference being it is the click of a button that can purchase a postcard of Cliff House, which can be sent to you from anywhere in the world.

Patrick Pound's practice relies on eBay, as he is well aware, '...eBay opens up large chunks of the world, a flood of images of all types, and it comes with its own search-engine logic that actually becomes part of the work. ${ }^{92}$ The intersections that are an essential element of Pound's display aesthetic reflect the way the World Wide Web functions. In this discussion it is important to acknowledge that, while the World Wide Web and the internet are generally seen as the same thing, the internet can be compared to back-end infrastructure and the World Wide Web is akin to the front-end interface. In essence, the internet fundamentally exists to connect computers (clients) to other computers (clients). When information is transmitted between clients using the internet it is sent in smaller 'packets' to the client receiving the information. Ironically, the language used to describe the internet has dialectical similarities to that used in retail (or eBay).

The information on eBay, like the World Wide Web, is categorised and sorted using metadata, whether words or images. ${ }^{63}$ Pound uses Google Translate to 'broaden his reach' and ensure that everything is visible to him. ${ }^{64}$ Pound observes that the 'hunt' for items on eBay can be seen as akin to being a photographer:

There is a peculiar relationship between my eBay searching and collecting of images and what has come to be called 'street photography'. When I click 'BUY'

\footnotetext{
${ }^{61}$ Picard, "The Great Exhibition."

${ }^{62}$ Finch, "A Conversation: Patrick Pound and Maggie Finch," 28.

${ }^{63}$ eBay News Team, "An Easier Way to Search EBay: Computer Vision with Find It On EBay and Image Search Is Now Live," Our News, October 15, 2017, https://www.ebayinc.com/stories/news/an-easier-way-to-search-ebay-computer-vision-withfind-it-on-ebay-and-image-search-is-now-live/.

${ }^{64}$ Cox, "Scouring EBay for Art with Patrick Pound."
} 
it is like when a street photographer snaps a particular moment. The street photographer's point-and-shoot is my 'point of sale', my decisive moment (laughs). The mouse is my camera. My scrolling through the world of readymade photographic documents is strangely related to that of the flâneur and the ragpicker and the street photographer. ${ }^{65}$

Even as Pound was installing The Great Exhibition, he was buying items on eBay. ${ }^{66}$ In his interview with Pound, reporter Will Cox notes: 'I meet Pound a couple of weeks before his NGV show opens. He still isn't finished adding things in. 'I'm always buying," he says. He gets out his phone and checks eBay. "I'm buying right now." 67 While seemingly automated, this process still takes time. As items are bought on eBay, they arrive one by one through the postal system.

To better understand how Pound's process works, I, too, delved into the world of second-hand consumerism on eBay. Taking my cue from Pound and Evans, I searched for 'Cliff House postcard' on eBay. With several hundred results from a variety of different viewpoints and eras to choose from, I added a few postcards similar to the ones in Pound's The Cliff House (2016-2017) collection to my personal 'Watch List.' Once in that Watch List, eBay automatically categorised the items and also offered me the ability to categorise the items into lists myself. After a few items had been added, the website started to suggest other similar items. One of these suggestions was postcards taken from the vantage point of the walkway around the Cliff House. All the postcards taken 'from Cliff House' depict a beach sprawling with people, as if the photographer of the Cliff House postcards might be able to be spotted among the crowds. Pound writes that the process of related suggestions to purchase on eBay is like being led down a 'false path' but '[s]ometimes those false paths have the best views (laughs). ${ }^{98}$ It was as if I somehow was turning my camera around towards Patrick Pound when I clicked 'BUY.'

\footnotetext{
${ }^{65}$ Finch, "A Conversation: Patrick Pound and Maggie Finch," 28.

${ }^{66}$ Cox, "Scouring EBay for Art with Patrick Pound."

${ }^{67}$ Ibid.

${ }^{68}$ Finch, "A Conversation: Patrick Pound and Maggie Finch," 22.
} 
I eagerly awaited the arrival of each of my postcards in the mail as they were transported across the world. The first envelope to arrive was from Germany and, ironically, used stamps featuring Heinz Sielmann, the wildlife photographer and documentary film maker [Fig. 57]. Encased in a plastic slip, the postcard had signs of wear; with bumped corners and bends, it was visibly aged. The postcard had originally been sent to Switzerland from California. The German phrase written on the back, 'Grüsse aus California', translates to 'Greetings from California.' The postcard is just one of four that will arrive, via eBay, to Wellington, New Zealand. The second arrival was from Massachusetts, United States of America. Comparing the two postcards, it is possible to establish that the one from the United States was taken before the one from Germany as the seawall and pier had not been built [Fig. 58]. It was easy for me to understand how someone could slip into obsession.

A shared feature of the postcards I had bought on eBay was that the photographs had all been taken from the same place on the walkway around the Cliff House and that same place is now occupied by a camera obscura [Fig. 59]. Another irony I noted was that, despite the Cliff House's implicit presence within the scene, all of these postcards made it invisible. These details are, however, superfluous without the context of Pound's vast Cliff House collection and its link back to Walker Evans. This is perhaps expressed best by Pound: 'My collection works rely on existing documents. Meaning can be found in the accumulation of details. ${ }^{69}$

\section{Georges Perec and the OuLiPo}

Georges Perec and the OuLiPo group are frequently acknowledged by Pound as being a foundational influence on his practice. According to Jacques Roubaud, 'the activity of the Oulipo today is largely inspired by Perec's example as a member of the group. ${ }^{70}$ Pound reveres his copy of Perec's Life: A User's Manual (1978),

\footnotetext{
${ }^{69}$ Pound, Documentary Intersect, 1.

${ }^{70}$ Mark Wolff, "Invoking the Oracle: Perec, Algorithms and Conceptual Writing," in The Afterlives of Georges Perec, ed. Rowan Wilken and Justin Clemens (Edinburgh, UK: Edinburgh University Press, 2017), 98.
} 
which his mother gave him when he was younger, calling it a 'treasure. ${ }^{71}$ Perec's seminal works, Les Choses (1965) and Life: A User's Manual (1978), have clearly resonated with Pound as they are referenced within The Great Exhibition. One of the site-specific installations, The collection shelves (1999-2017) [Fig. 60], consists of 19 small collections:

These collections tend to be smaller than others seen throughout this exhibition, and each one operates according to a very specific constraint. Their organisational technique derives from Pound's interest in the Oulipo group of writers [...] specifically, in the writing of key member Georges Perec. ${ }^{72}$

Each of the collections within The collection shelves demonstrates a constraint applied by the artist. For example, 26 brown things (2002) consists of, as the title would suggest, '26 brown things' - a brown mug, a brown blanket, a brown jug, a brown suitcase and more [Fig. 61]. Pound explains that his constraint for this collection was that he had to buy all the objects from one second-hand shop, in one day. ${ }^{73} \mathrm{He}$ cites his disappointment that he was not questioned about his purchases: 'I thought the shopkeeper would say, "Having a brown day are we?" but she did not say a thing. ${ }^{74}$ Without this process of constraint, there would be no order or end point. As Pound quips:

If you buy two brown vases, that's decorating. If a hay fever sufferer buys twenty brown vases, that's collecting. If the archiving artist as collector buys twenty-six brown vases, that's an exhibition. ${ }^{75}$

Another collection, The Collector (2000-2017), features 18 different editions of John Fowles' The Collector (1963), including a review copy [Fig. 62]. The irony of this collection emerges once you are familiar with Fowles' novel - the title refers to the protagonist, who is obsessed with a woman he admires and, so, kidnaps or

\footnotetext{
${ }^{71}$ Finch, "A Conversation: Patrick Pound and Maggie Finch," 17.

${ }^{72}$ Finch, "The Great Exhibition Artwork Labels," 259.

${ }^{73}$ Finch, "A Conversation: Patrick Pound and Maggie Finch," 17.

${ }^{74}$ Ibid.

${ }^{75}$ Pound, "The Gallery of Air."
} 
'collects' her. This scope of collecting amuses Pound. As he says: 'It is a novel about a photographer, a pervert and a collector rolled into one (laughs). ${ }^{, 76}$

The collection shelves demonstrates the application of 'constraint' that both the OuLiPo and Georges Perec are recognised for. Pound constructs his collections according to Oulipian 'rule-based systems with indeterminate exceptions. ${ }^{, 77}$ It is the exceptions that are important for Pound, as they were for Perec:

Perec insists it is important to include anti-constraints within a system of constraints: '[the system] must not be rigid, there must be some play in it, it must, as they say, "creak" a bit; it must not be completely coherent $[\ldots] .{ }^{78}$

For Mark Wolff, the OuLiPo are important because their conceptual writing process mimics that of computer algorithms. ${ }^{79}$ An algorithm, like the Markov Chain used online, is enhanced by these 'creaks' as articulated by Perec. When I searched for Cliff House, it was a 'creak' in the algorithm that suggested instead 'From Cliff House' opening up a new category for my search.

Perec believed that 'simultaneity' and 'discontinuity' could be 'adapted to writing so as to create "open" works that would involve their readers as co-producers of meaning. ${ }^{80}$ We can see these concepts applied to The Great Exhibition - within each of the gallery spaces, 'simultaneity' is applied, so each room can be read within the same frame of reference, by the viewer. Moving between gallery spaces, there is a puncture, a 'discontinuity' between the rooms, and break in the continuity. Each space operates independently from the next, demonstrating a different curatorial logic within each space. Take, for instance, the hallway and first gallery in The Great Exhibition: both are dark and filled with vernacular photographic collections like The photographer's shadow and Damaged. After proceeding through a set of black drop curtains, we enter a large, white gallery

\footnotetext{
${ }^{76}$ Finch, "A Conversation: Patrick Pound and Maggie Finch," 17.

${ }^{77}$ Wolff, "Invoking the Oracle: Perec, Algorithms and Conceptual Writing," 87.

${ }^{78}$ Wolff, 86.

${ }^{79}$ Wolff, 85 .

${ }^{80}$ Ribière, "Georges Perec's Enduring Presence in the Visual Arts," 27.
} 
space filled solely with The Museum of There / Not there. These contextual shifts are emblematic of how The Great Exhibition operates. Each gallery space functions within a set of rules, but there is a point of intersection and connection to the following collection or gallery space. In the interview with Maggie Finch, Pound confesses:

Actually, I don't know if I should tell you this but I have applied a second constraint as a thread throughout the exhibition. In every one of my collection works I have a thing or a photo that could be in another of the collection works. So, in The photographer's shadow [...] photo collection there is a photographer's shadow snapshot that also features a passing car, and so on. ${ }^{81}$

The photographer's shadow permeates through the site-specific installations in The Great Exhibition. In last gallery, The sleeping gallery (2016-2017), Pound's assemblage, People from behind (2016-17), hung on the wall. Within that assemblage is a painting from the NGV collection, Félix Vallotton's Point du Jour, banks of the Seine (Point du Jour, bords de la Seine) (1901) [Fig. 63]. Vallotton has painted a man with his back to us, standing near the edge of the Seine; his elbows are raised to his side and his shoulders are slightly hunched. With his shadow cast before him, we can only hypothesise that he might be taking a snapshot photograph of the Seine featuring his own shadow. Vallotton's Point du Jour is a pertinent reminder of the many intersections at play within The Great Exhibition.

\section{Thoughts-of-sorts}

The use of Perecian logic by Pound is further exemplified in his collaboration with Rowan McNaught in Thoughts-of-sorts (2016-2017) [Fig. 25]. This work exists as an algorithm, which was staged for The Great Exhibition but is still accessible online. ${ }^{82}$ Thoughts-of-sorts is referred to by Pound as 'a bit like the unthinking brain of the show. Or, maybe, the engine room. ${ }^{83}$ The work in question is a piece

\footnotetext{
${ }^{81}$ Finch, "A Conversation: Patrick Pound and Maggie Finch," 15.

${ }^{82}$ Rowan McNaught and Patrick Pound, Thoughts of Sorts, 2017, Computer Programme, 2017, www.thoughts-of-sorts.com.

${ }^{83}$ Finch, "A Conversation: Patrick Pound and Maggie Finch," 31.
} 
of digital code made physically present within the site of the gallery through a desktop computer and large display screen:

For The Great Exhibition [McNaught] has assembled a new searching and sorting 'internet machine' that hunts for pictures such as those in my photo collections of pairs and then averages them and attempts to tell us what they might be, in an endless tragicomic kind of poetic thinking and sorting activity. This is not so much a collective memory generator as a data dream machine. ${ }^{84}$

Thoughts-of-sorts actively seeks out similar images and corresponding literary fragments from the collections of Pound and the NGV and contextualises these with online images and text. The Internet is, thus, deployed as a 'sorting machine,' seeking congruencies and connections. ${ }^{85}$

According to Mark Wolff, Perec's use of computer logic can be related to Alan Turing, who 'developed a theoretical construct of what he called the automatic machine,' which exploited a 'self-referential system [...] which is itself described by symbols and so can operate on its own description. ${ }^{96}$ Turing also developed the idea of the 'oracle machine,' arguing that some operations simply 'defy computation. ${ }^{87}$ Turing notes that the concept of the oracle 'cannot be a machine., 88 As Wolff extrapolates:

The oracle is thus a concept for imagining a more expansive computational process that distinguishes intuition from calculation and allows for a distributed procedure oscillating between insight and method [...] Rather than draining human work of any interest, programming will allow humans to relegate repetitive and determined procedures to the computer, freeing humans to pursue less predictable outcomes. ${ }^{89}$

Thoughts-of-sorts is proof of the demarcation between insight and method. The work is an attempt to reflect the logic of Pound's brain, in the form of an algorithm reflecting his thought processes. However, as Thoughts-of-sorts runs, it eventually

\footnotetext{
${ }^{84}$ Finch, "A Conversation: Patrick Pound and Maggie Finch," 31.

${ }^{85}$ Ibid.

${ }^{86}$ Wolff, "Invoking the Oracle: Perec, Algorithms and Conceptual Writing," 88.

${ }^{87}$ Ibid.

${ }^{88}$ Ibid.

${ }^{89}$ Wolff, 89.
} 
descends into repeated images of static or fragments of text about scissors, demonstrating that human intuition is required to ensure Thoughts-of-sorts can 'sort its thoughts.' Wolff summarises this phenomenon: 'In other words, computers can be programmed to produce results but human insight must seed the processor with erratic instructions to produce original and meaningful output.' 90 This observation directly relates to the work of Perec, which emphasises that the 'use of constraints allows for variation and mutation. ${ }^{91}$

The Great Exhibition can be seen as Pound's ode to Perec's book Thoughts of Sorts (1985), which also helps clarify how Pound operates. The collection of essays details many of Perec's thought processes, particularly in the last chapter, 'Thoughts of Sorts / Sorts of Thoughts,' where Perec discusses his methodologies, classification systems and lists, while also implementing them throughout the chapter. As Perec's translator notes:

It brings together a range of Perec's special contributions to modern literature: his use of the fragment as a literary form; his pursuit of exhaustiveness, combined with his often cunning demonstrations that nothing is ever complete; his fascination with hierarchies, orders, and indexing devices; and his passion for the heteroclite. ${ }^{92}$

We can think about The Great Exhibition within a similar framework. Pound uses image and text fragments; he pursues exhaustiveness, albeit within the genre of vernacular photography; and he demonstrates that 'nothing is ever complete,' with his vitrines of unsorted photographs and overlapping classifications.

The idea of the 'puzzle' is also clearly important to Pound. The wall text at the entrance of the exhibition states: 'All of the works in Patrick Pound: The Great Exhibition function as pieces in a vast puzzle. That puzzle amounts to an, often, tragicomic reflection of life. ${ }^{93}$ Perec's Life: A User's Manual (1978) is a book

\footnotetext{
${ }^{90}$ Wolff, 99

${ }^{91}$ Ibid.

${ }^{2}$ David Bellos, "Introduction," in Thoughts of Sorts, Georges Perec, trans. David Bellos (Boston, MA: David R. Godine Publisher, 2009), XI.

${ }^{93}$ Finch, "The Great Exhibition Artwork Labels," 17.
} 
about puzzles and is, fittingly, written and constructed like a puzzle. The 'Preamble' describes the process of the 'art' of jigsaw puzzles:

[...] you can look at a piece of a puzzle for three whole days, you can believe that you know all there is to know about its colouring and shape, and be no further on than when you started. The only thing that counts is the ability to link this piece to other pieces, and in that sense the art of the jigsaw puzzle has something in common with the art of go. The pieces are readable, take on a sense, only when assembled; in isolation, a puzzle piece means nothing - just an impossible question, an opaque challenge. ${ }^{94}$

Ironically, I had spent three whole days looking at The Great Exhibition and also felt no closer to solving the puzzle Pound had set. This is because, according to Perec: 'A well-made puzzle is composed of pieces that purposefully introduce false information to disrupt methodological thinking...' 95 These disruptions, I believe, are what Wolff identified as the 'less predictable outcomes' idealised by the conception of the oracle. ${ }^{96}$ This reminds us of Orson Welles, when he said that '[e]xperts are the new oracles ... They speak to us with the absolute authority of the computer $[\ldots]$ And we bow down before them. They're god's own gift to the faker.' 97

In practice, non-conforming information is introduced by Pound and these disruptions are visible as the intersections and matrixes within The Great Exhibition: According to Pound:

Those unconscious pathways set off on by particular and predetermined systems, which generate associations and suggestions that are sometimes useful and other times peculiar or fantastic and wonderful even, have fed back into how I rethink the way things might be found and seen to fit together. ${ }^{98}$

\footnotetext{
${ }^{94}$ Georges Perec, Life: A User's Manual, trans. David Bellos, Vintage Classics (London, UK: Random House, 2008), unpaginated.

${ }^{95}$ Wolff, "Invoking the Oracle: Perec, Algorithms and Conceptual Writing," 96.

${ }^{96}$ Wolff, 89.

${ }^{97}$ Welles et al., $F$ for Fake.

${ }^{98}$ Finch, "A Conversation: Patrick Pound and Maggie Finch," 17.
} 
This pathway of association is demonstrated in Drive by (en passant), which hangs in a horizontal sequence around the gallery and intersects with the vertical The Museum of holes (2016-2017) at a vernacular photograph of a car with bullet holes [Fig. 64]. The Museum of holes also features a knife-block that could be part of Knife blocks (1999-2017) within the Collection shelves [Fig. 65] in a pattern of practice that continues throughout the exhibition, demonstrating that Pound's collections and classifications are malleable within his sorting algorithm in that iteration of the work.

\section{Robert Rauschenberg and Formulaic Intersections}

In The Great Exhibition, there is one gallery space that exemplifies the importance of algorithmic logic within Pound's practice and exhibition. Geoffrey Batchen has referred to the room as a 'tapestry of connectivity that models the algorithmic logic of Pound's own collecting habits. ${ }^{99}$ He refers to it as the 'penultimate room' where '[a]ll of this quietly echoes the distribution, dissemination and sorting machinery of the internet search engines and of the selling sites as well, of course. ${ }^{, 100}$ The room consists of collections intersecting with other collections, creating a complex grid system of aleatory associations [Fig. 66]. Batchen notes that, for an exhibition 'seeming to be devoted to the analogue era, Pound's exhibition is really all about the internet $[\ldots]$ we have been allowed a glimpse of a hitherto invisible algorithm.' ${ }^{101}$

To better understand Pound's use of intersections in The Great Exhibition, we can position his practice alongside the shifts in Robert Rauschenberg's practice in the 1960s, which pre-empted many contemporaneous archiving photographic practices. Rosalind Krauss examines Rauschenberg's innovative use of photography, archives, grids and ordering in her essay, 'Perpetual Inventory' (1999). She suggests that while ' $[\mathrm{t}]$ he photographic archive was not wholly foreign to

\footnotetext{
${ }^{99}$ Batchen, "Keepers: Patrick Pound and the Art of Collecting," 44.

${ }^{100}$ Finch, "A Conversation: Patrick Pound and Maggie Finch," 15.

${ }^{101}$ Batchen, "Keepers: Patrick Pound and the Art of Collecting," 44.
} 
Rauschenberg,' there was a marked shift in his integration of those photographic archives into silkscreens [Fig. 67]. ${ }^{102}$ This shift in Rauschenberg's work appeared at about the same time as his manifesto, 'Random Order,' published in the first issue of Location in Spring, 1963. ${ }^{103}$ Krauss reiterates that:

Rauschenberg's work was undergoing a shift, one that marked all his immediately succeeding work and the vast majority of what he went on to do in the following years. The shift was to photography not only as the image bank on which his pictorial practice would then rely $[\ldots]$ but as a new conception of the pictorial itself. ${ }^{104}$

At that same time, Andy Warhol had started using the photomechanical silkscreen as a medium (August 1962) and Roland Barthes had recently published 'The Photographic Message' (1961). ${ }^{105}$ In 1966, Rauschenberg observed, in hindsight, that he had 'insisted on the challenge of being restricted by a particular subject where it meant that I'd have to be involved in symbolism.' 106 'Random Order' is seen by Krauss as that precise moment when Rauschenberg shifted to the 'connotational' and 'symbolic' use of photographs in his new silkscreen series:

[T] he formula for the entire silkscreen series is to be a loose grid of enframed photographic spaces, that seems to present one with nothing so much as a visual archive: the storage and retrieval matrix of the organized miscellany of images, which presents the memory as a kind of filing cabinet of the mind. ${ }^{107}$

We can compare Rauschenberg's utilisation of his archive with that of Pound in The Great Exhibition. A literal interpretation might be that the 'loose grid' of arrangements in The readers (2016-2017) represents the 'visual archive' [Fig. 68]. It is, however, the gallery of intersections that actually presents an interpretation of the 'filing cabinet of the mind.' With each intersection we can observe mechanisms at play as the archive of Pound's brain is classified and connected. Take the

\footnotetext{
${ }^{102}$ Rosalind Krauss, “Perpetual Inventory,” October 88, no. Spring (1999): 107.

${ }^{103}$ Krauss, 93.

${ }^{104}$ Krauss, 95 .

${ }^{105}$ Krauss, 98.

${ }^{106}$ Robert Rauschenberg cited in Krauss, 103.

${ }^{107}$ Krauss, "Perpetual Inventory," 107.
} 
intersection of Drive by (en passant) with The Museum of holes for example: these two works demonstrate Pound's retrieval and filing system within this particular iteration of the collections. Pound's practice echoes Rauschenberg when he 'formulated the term "random order" to characterize the unstoppable connectivity of images and objects. ${ }^{108}$

The genesis of Pound's practice corresponds to Rauschenberg's practice in other ways. For example, Rauschenberg's interest in photography resulted in his collection of an 'archive on the basis of certain preconceived categories.' ${ }^{109}$ While collecting photographs within categories was not a revolutionary concept, even at that time, Rauschenberg does provide a historical precedent when consideration is given to the use of those archives in his work. Rauschenberg and his assistants worked to 'arrange this material in prescribed categories - athletes, space travel, domestic objects, transport, and American emblems, among others... ${ }^{110}$ Just as Pound scours eBay for the categories of vernacular photographs he is collecting, Rauschenberg combed print media searching for 'amateur-type' photographs, which resulted in:

... the exploitation of serialization and repetition; the coordination of the framed photographic image with the geometrically patterned layout of the grid; and the ultimate quarry, which is the now highly problematic space of memory. ${ }^{111}$

Pound's formula of intersections should, therefore, be contextualised in relation to those of Rauschenberg's works that are related to his manifesto, 'Random Order.'

\footnotetext{
${ }^{108}$ National Collection of Fine Arts, Robert Rauschenberg (Washington, DC: National Collection of Fine Arts, Smithsonian Institution, 1976), 7.

${ }^{109}$ Krauss, "Perpetual Inventory," 110.

${ }^{110}$ Ibid.

${ }^{111}$ Krauss, "Perpetual Inventory," 111.
} 


\title{
Conclusion: On Reflection
}

\author{
In the name of completion, we would like to believe that a single order exists \\ which would allow us immediate access to knowledge; in the name of the \\ ungraspable we wish to believe that order and disorder are two identical terms \\ signifying chance. ${ }^{1}$ \\ Georges Perec
}

I originally undertook this research in order to understand how Patrick Pound: The Great Exhibition might be cited as an example of how public institutions can successfully collaborate with artists. I was hoping to demonstrate how underutilised collections of vernacular photography could make sense when transposed into an exhibition. What actually emerged through the course of this research was my realisation that The Great Exhibition was operating within a deceivingly complex conceptual framework. I shifted the direction of my research to explore some broader questions I had about Pound's practice. How has Patrick Pound's practice informed The Great Exhibition? How does The Great Exhibition exemplify the interconnectedness of art-historical discourses, collecting and curating? What is the curatorial logic at play within The Great Exhibition? What is the point of it all?

A persistent challenge that arose throughout the research process was a lack of information, and, paradoxically, too much information. For an artist as prolific as Pound, there was a discernible absence of a historiography to trace his practice. More recently, Geoffrey Batchen, Maggie Finch and Daniel Palmer have contributed to the scholarship surrounding Pound; but there is an obvious gap in the discourse prior to this. There was, however, an exhibition history traceable through a mixture of reviews and exhibition ephemera, which was critical in informing this thesis. The artist files that are kept about Pound are fragmented, sporadic and random; as if a 'nationalist stamp' had branded him too Australian to be in the New

${ }^{1}$ Perec, Thoughts of Sorts, 29. 
Zealand archives. On the other hand, having his work shown in the reading room of the AGNSW for The Photograph and Australia signifies Pound's outsider status in Australia. It is an interesting position for this expatriate artist to occupy and one that has consistently challenged my research methodology.

Pound's absence from discourse prompted me to explore his earlier practice - from around the time he graduated from Elam School of Fine Arts in 1987. After all, how could I understand The Great Exhibition as a 'survey of Patrick Pound's art of collecting,' without an understanding of his practice as a whole $?^{2}$ Some of the earliest catalogues led me down false paths: one of these involved trying to verify that perhaps Ezra Pound was related to Patrick Pound in some tangential way. But Pound was right when he said '[s]ometimes those false paths have the best views." The fictions I uncovered are reflective of Pound's longstanding examination of biography, authorship and identity, which are made tangible in his works and exhibitions such as Fragments and Fakes, The Tailor's Library and C.V.-a work in progress. In essence, however, Pound's elusiveness freed my research from a chronological biographical examination of his practice and licenced me to focus on the critical intersections that have informed The Great Exhibition.

When reckoning with the scale of The Great Exhibition, there is an inherent desire to sort information into discrete categories; to package it in order to make sense of it - but nothing is easily compartmentalised in The Great Exhibition. On reflection, this thesis mirrors some of Pound's own methodologies. In order to reconcile the massive amount of information and repetitious ideas presented in The Great Exhibition I found myself using categories to arrange my research. Applying a linear structure to Pound's non-linear practice felt somehow incongruous and, so, this thesis is somewhat emblematic of the interconnected nature of The Great Exhibition. With over 4,000 items from Pound's collection and more than 300 from the NGV, there was no chance to analyse and contextualise everything. Pound has

\footnotetext{
${ }^{2}$ Finch, "The Great Exhibition Artwork Labels," 2017, 18.

${ }^{3}$ Finch, "A Conversation: Patrick Pound and Maggie Finch," 22.
} 
applied layers of constraints throughout the exhibition, proving that his categories are malleable. For example, Félix Vallotton's Point du Jour, banks of the Seine from the collection of the NGV could fit within The photographer's shadow or another of his categories, People from behind. In this exercise of taxonomy, Pound reflects on how institutions drive linear narratives; categorisation is, after all, an application of power. For Pound to impose his own order on the objects is to impose his own narrative or, as he terms it, give 'the works selected a temporary 'sabbatical' from their agreed meanings. ${ }^{\text {' }}$

Pound's re-contextualisation of objects into his own systems of meaning in The Great Exhibition could be seen as one elaborate 'dad joke.' There are many humorous juxtapositions, like the mask of Donald Trump positioned beside Robert Musil's book The Man Without Qualities. The positioning of the etching of Bennelong within the 'displacement' category, however, draws attention to Australia's racist past and generations of Aboriginal genocide. Pound asks us to consider how art history has operated to affirm or negate narratives and to reflect on what that looks like.

This is where Ian Burn's question, 'Is art history any use to artists?', comes to mind. Pound's deep understanding of art history is clearly central to his practice and his $\mathrm{PhD}$ thesis is only one indication of that. An understanding of art history is crucial to reading The Great Exhibition, which is reflective of photographic, literary and curatorial histories. For example, the history of the readymade is referenced through Pound's inclusion of an upturned bicycle wheel in The Museum of holes, emulating Duchamp's Bicycle Wheel; The game of things has an affinity with Duchamp's Boîte-en-valise works; the sheer accumulation of 'found' photographs; and utilisation of NGV's collection become his own 'readymades.' Pound turns art history around in on itself, on curators and on galleries and their collections. As

\footnotetext{
${ }^{4}$ Finch, "The Great Exhibition Artwork Labels," 2017, 18.
} 
Burn states: 'Art history has always been far too important to be simply left up to art historians. ${ }^{5}$

The thousands of vernacular photographs in The Great Exhibition are used by Pound to provide a history of photography. These private and personal photographs have historically been relegated to the domestic sphere, where snapshots functioned to preserve memories and affirm the family unit. When assembled en masse within The Great Exhibition, these boring, repetitive, ordinary snapshots challenge the arthistorical discourse of originality. The collection, Self portraits (2007-2017), draws attention to precedents of the selfie, a photographic genre that is generally considered to be a reflection of our contemporary condition. Looking at the collections of vernacular photographs assembled in The Great Exhibition, we recognise them as affirmations of a collective identity.

Pound is counted amongst a number of artists who have employed the use of vernacular photographs as found objects, including Erik Kessels and Joachim Schmid. I hope that I have demonstrated that, while he emulates their acquisitive traits, it is his continued iteration of their practices that is of note. Pound demonstrates that, by collecting 200 postcards of the Cliff House, he has recognised Walker Evans's process and, in its repetition, emphasised the connection. He is acutely aware of his relationship to artists with similar practices, to the point that he references them within the catalogue for The Great Exhibition, as well as through his collecting practices. A case in point is Kessels' series IN ALMOST EVERY PICTURE, which is a publication of vernacular photographs featuring a pair of twins [Fig. 69]. ${ }^{6}$ It is notable that the first vernacular photograph in The Great Exhibition is of a pair of twins, placed atop a plinth. Pound expands on this reference to Kessels by adding another seven plinths, topped with pairs of sculptures from the NGV's collection [Fig. 30]. He seems to be emphasising that, after all, nothing is original. Everything is an exercise in repetition.

\footnotetext{
${ }^{5}$ Burn, "Is Art History Any Use to Artists?," 14.

${ }^{6}$ KESSELSKRAMER, "IN ALMOST EVERY PICTURE 4," kesselskramerpublishing, N.D., http://kesselskramerpublishing.com/catalogue/in-almost-every-picture-4/.
} 
Pound's use of eBay and second-hand stores to source his material for The Great Exhibition forces visitors to question the point of it all. For Pound, it is through the obsessive accumulation of objects, the addition of detail and overwhelming nature of the show, that things start to make sense. When we reflect on a genre, we can see the pattern and fit the pieces of the puzzle together. What happens when 200 postcards of the Cliff House are placed in a horizontal sequence together? The answer is that we can see a reconstructed history of the Cliff House, as relayed by Pound's assemblage.

Pound not only utilises the internet but also emulates its structures with his algorithmic approach to categorisation, collecting and curation, all of which is exemplified in The Great Exhibition. An algorithm, like that used on eBay, enables users to connect to similar content based on their previous history of purchasing. The automation is not perfect, however, as the programme used in Thoughts-ofsorts demonstrates; its tendency to take false paths usually leads it to a screen of full of static - and it is unable to escape the monotony until it reboots. Pound betters the logic of the internet in his gallery of matrixes and intersections. When Drive by (en passant) intersects with The Museum of holes, Pound is connecting them to each other with a logic that defies computation [Fig. 64]. Turing's conception of the automatic machine, which still characterises modern computing, came to inform the automatic writing processes of the OuLiPo. Georges Perec recognised that automation must allow for 'creaks' - there must be a balance between 'insight' and 'method. ${ }^{77}$ Pound demonstrates the 'creaks' within his system through the malleable constraints he applies to the categories of vernacular photographs and, also, the curatorial logic of their display. Drive by (en passant) intersecting with The Museum of holes exemplifies how the internet operates. It is (literally) Patrick Pound's matrix. There is nothing 'random' about this order. Every intersection and decision has been carefully considered. An understanding of

\footnotetext{
${ }^{7}$ Wolff, "Invoking the Oracle," 89.
} 
the internet has, therefore, been critically important to my analysis of The Great Exhibition.

The 'internet of things' is a phrase commonly used to describe how devices, or things, are connected through the internet. It is a phrase that could be used to expound on The Great Exhibition; not because each object is connected through the actual internet but because everything is connected using the logic of the Internet. Using an algorithmic logic helps us understand Pound's curatorial approach to The Great Exhibition. While it could be advantageous to my research to suggest that the puzzle of The Great Exhibition can be solved, I do not believe Pound's intention is to provide a linear path to a singular meaning - because, although 'we would like to believe that a single order exists which would allow us immediate access to knowledge,' this is not how a puzzle works - sometimes there are only detours. 


\section{Illustrations}

Ray Fox is currently Australia's 1996 writer in residence at Cité International
des Arts in Paris France.

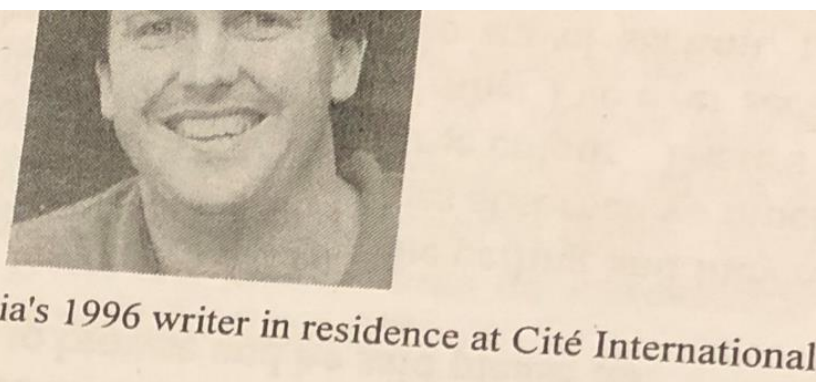

Patrick Pound is an artist based in Melbourne Australia. 'The Tailor's Library'
is his nineteenth solo exhibition.

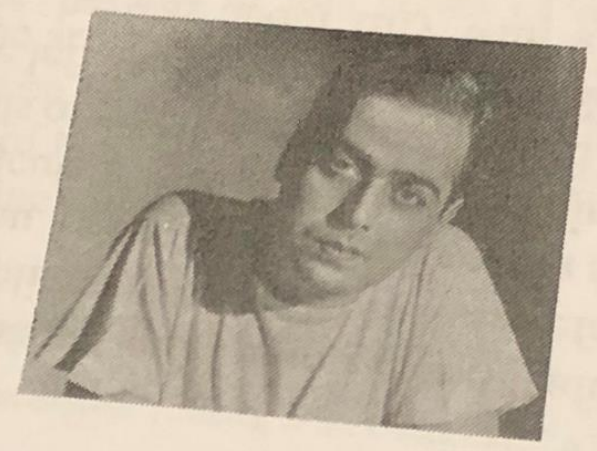

Fig. 1: Detail of Patrick Pound, The Tailor's Library. (Melbourne, VIC, Michael Wardell Gallery, 1996). Accessed at Te Aka Matua Research Library, Te Papa Tongarewa. 


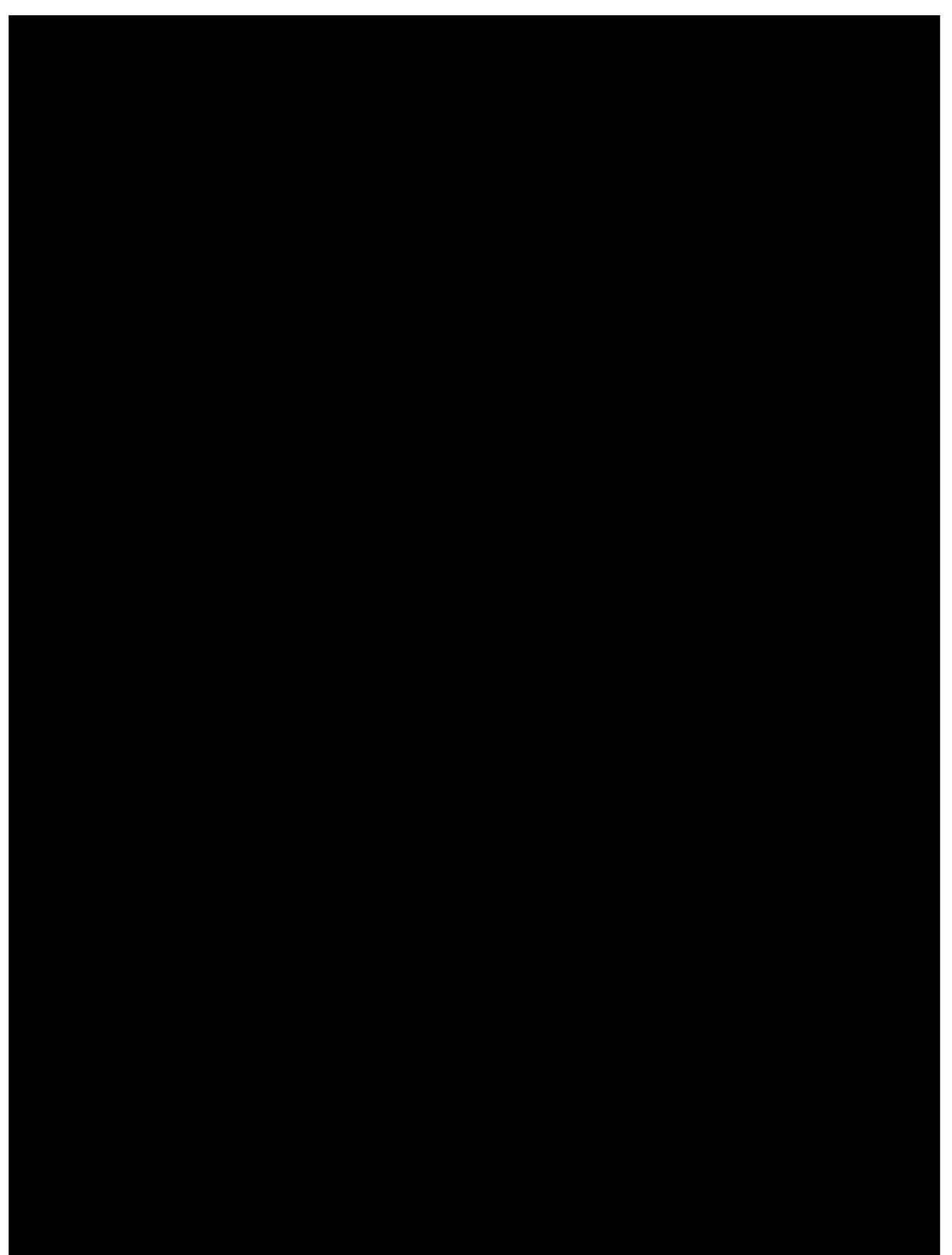

Fig. 2: Discogs, Lester Gaba, n.d. Retrieved from https://www.discogs.com/artist/2756088-Lester-Gaba. Accessed 12 May 2018. 


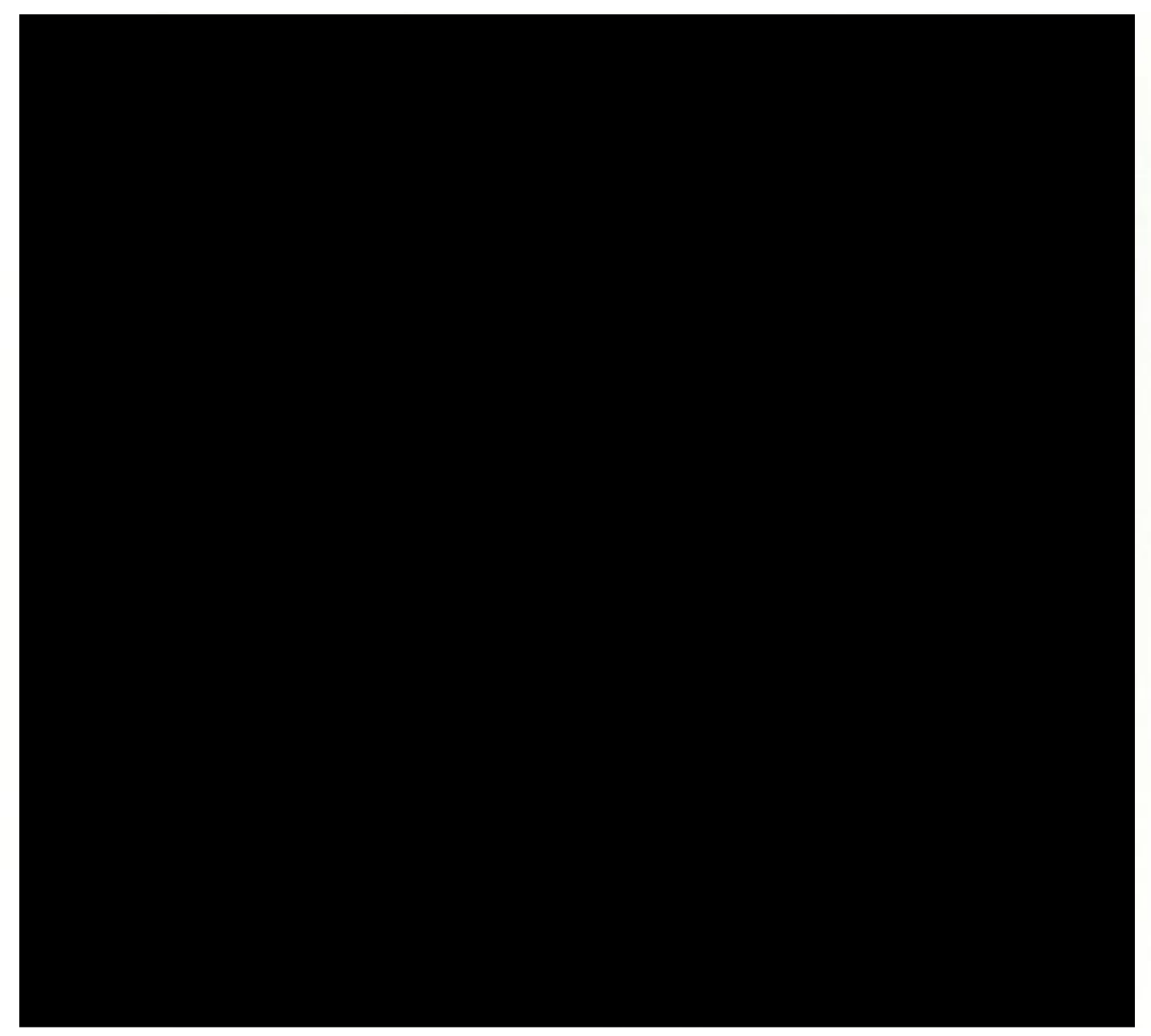

Fig. 3: Rowan McNaught and Patrick Pound, The compound lens project, 20142015, computer programme. Detail retrieved from http://compound-lens.com/. Accessed 12 May 2018 


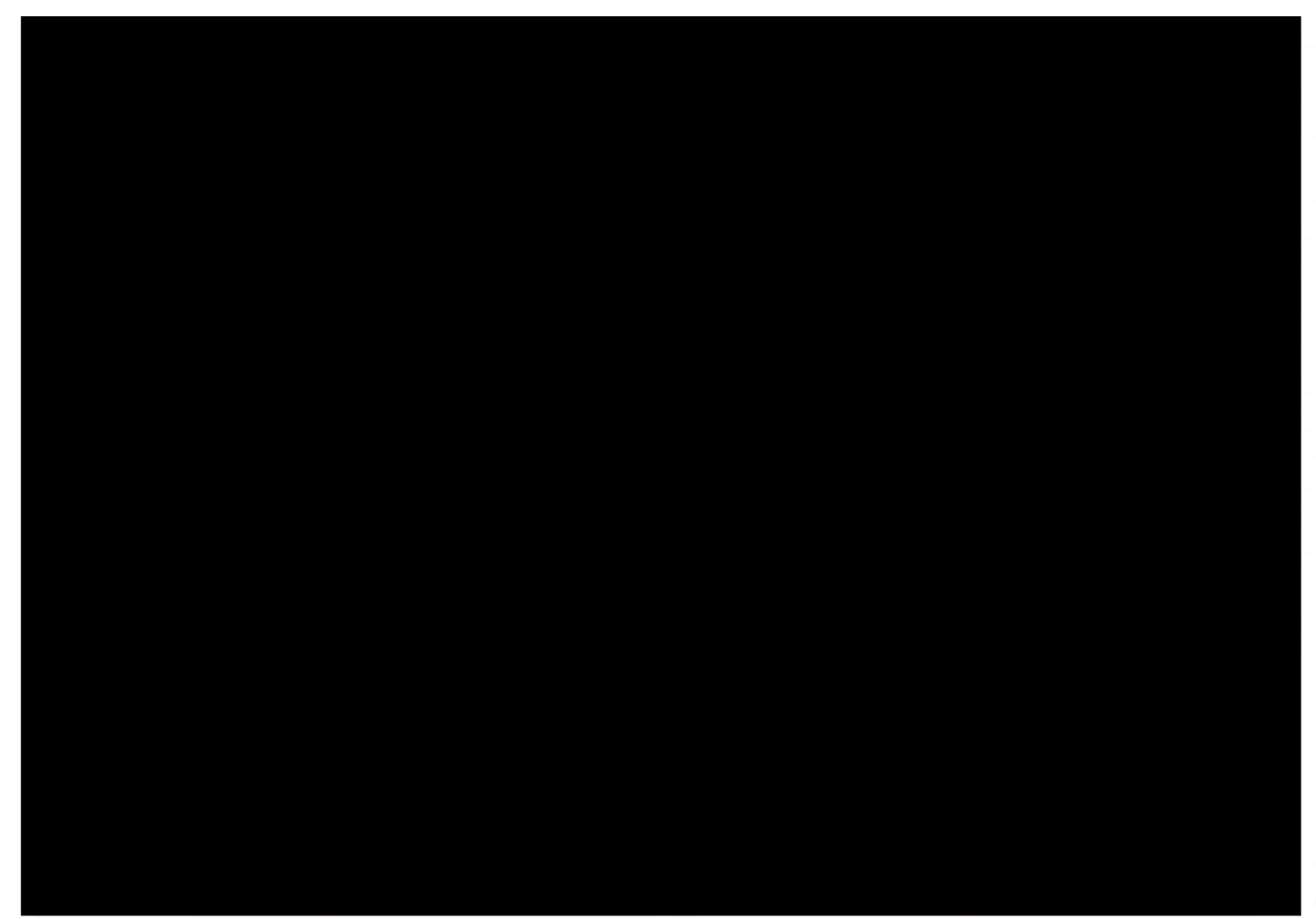

Fig. 4: Rowan McNaught and Patrick Pound, The compound lens project, 20142015, computer programme. Detail retrieved from http://compound-lens.com/. Accessed 12 May 2018 


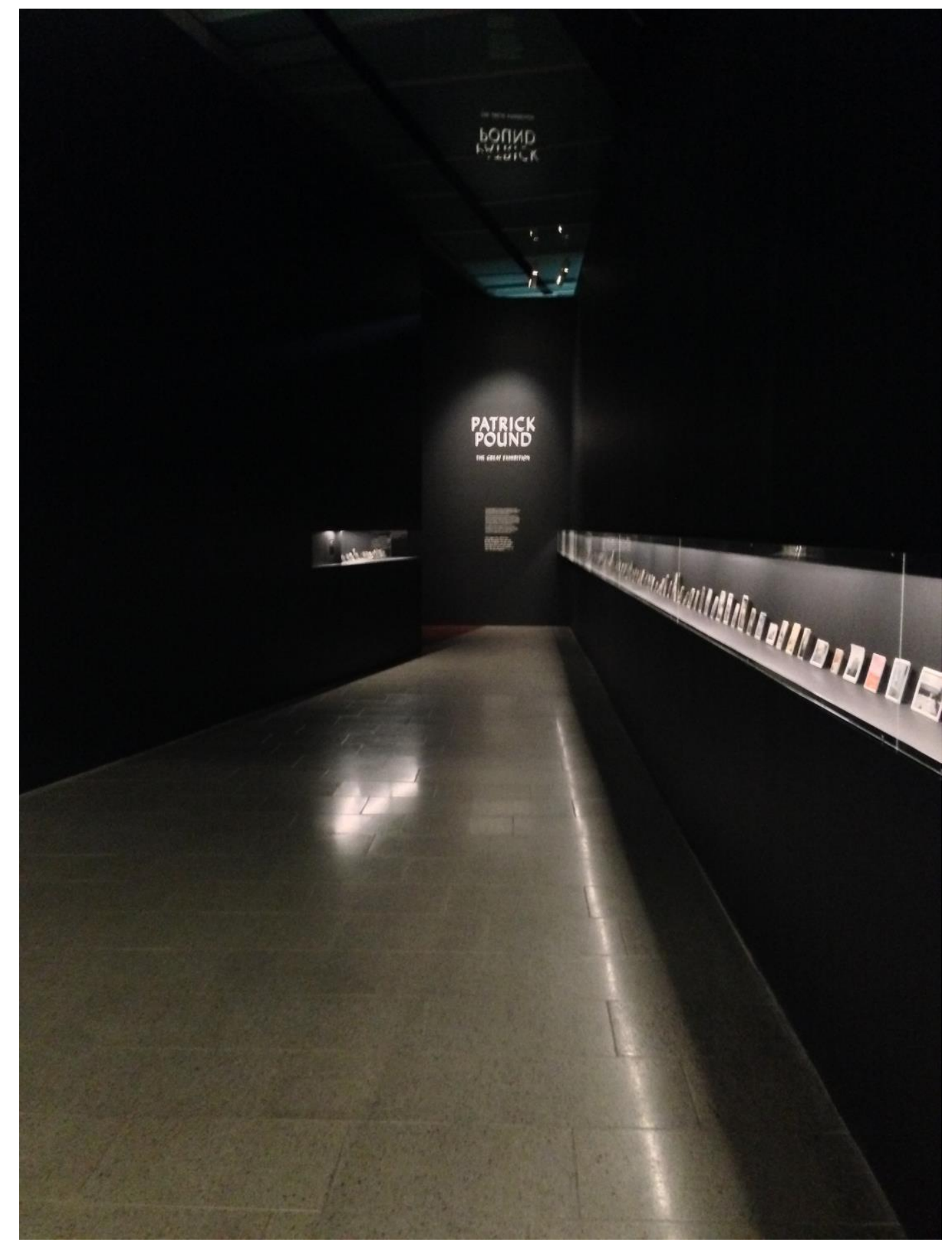

Fig. 5: Exhibition title at Patrick Pound: The Great Exhibition, May 2017, photograph by author. 


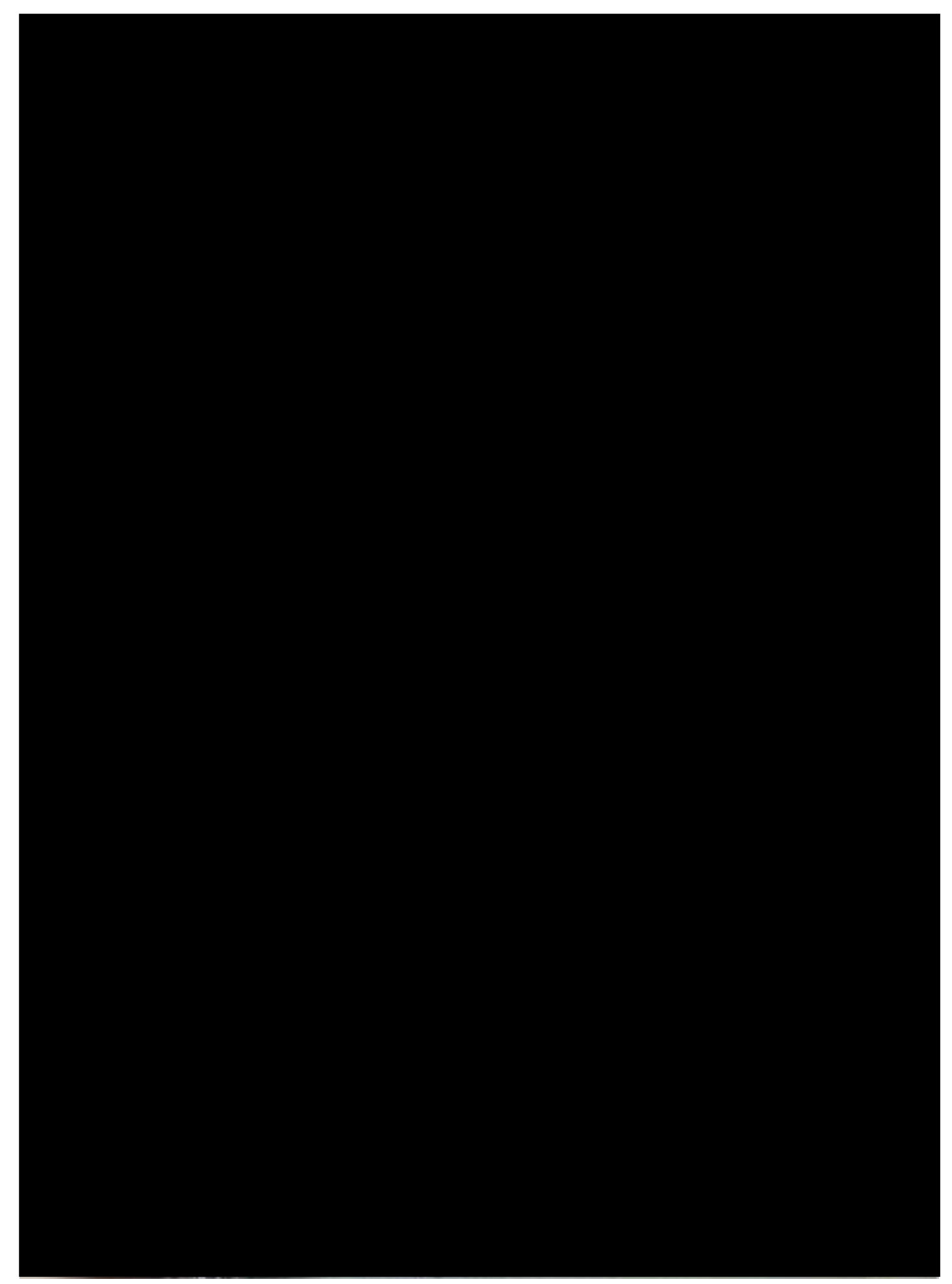

Fig. 6: Detail of Patrick Pound's falsified identity in Peter Hill, 'An Encyclopaedia of Patrick Pound's Superfictions,' Photofile 91 (December 2010): 61). 


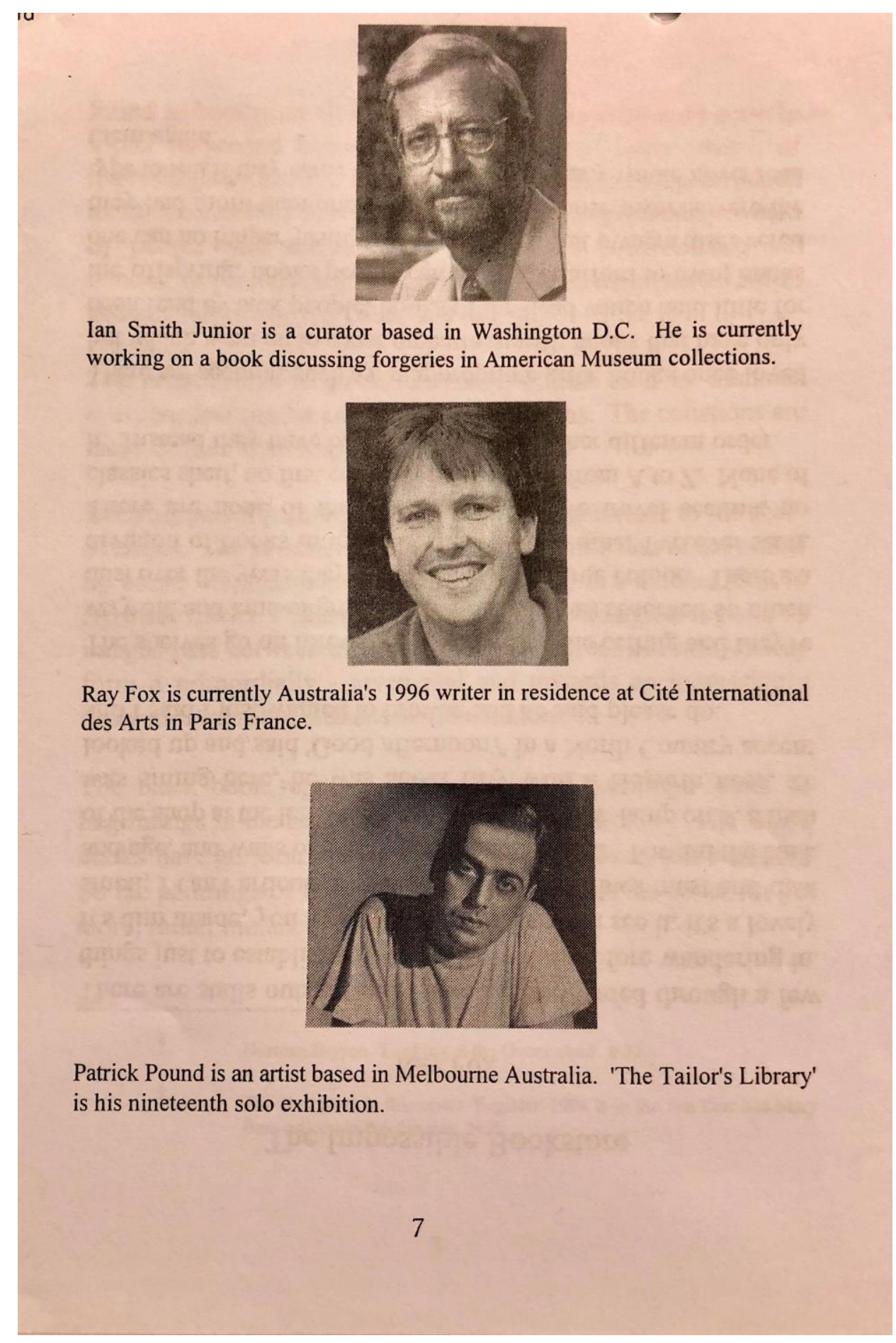

Fig. 7: Detail of Patrick Pound, The Tailor's Library. (Melbourne, VIC, Michael Wardell Gallery, 1996). Accessed at Te Aka Matua Research Library, Te Papa Tongarewa. 


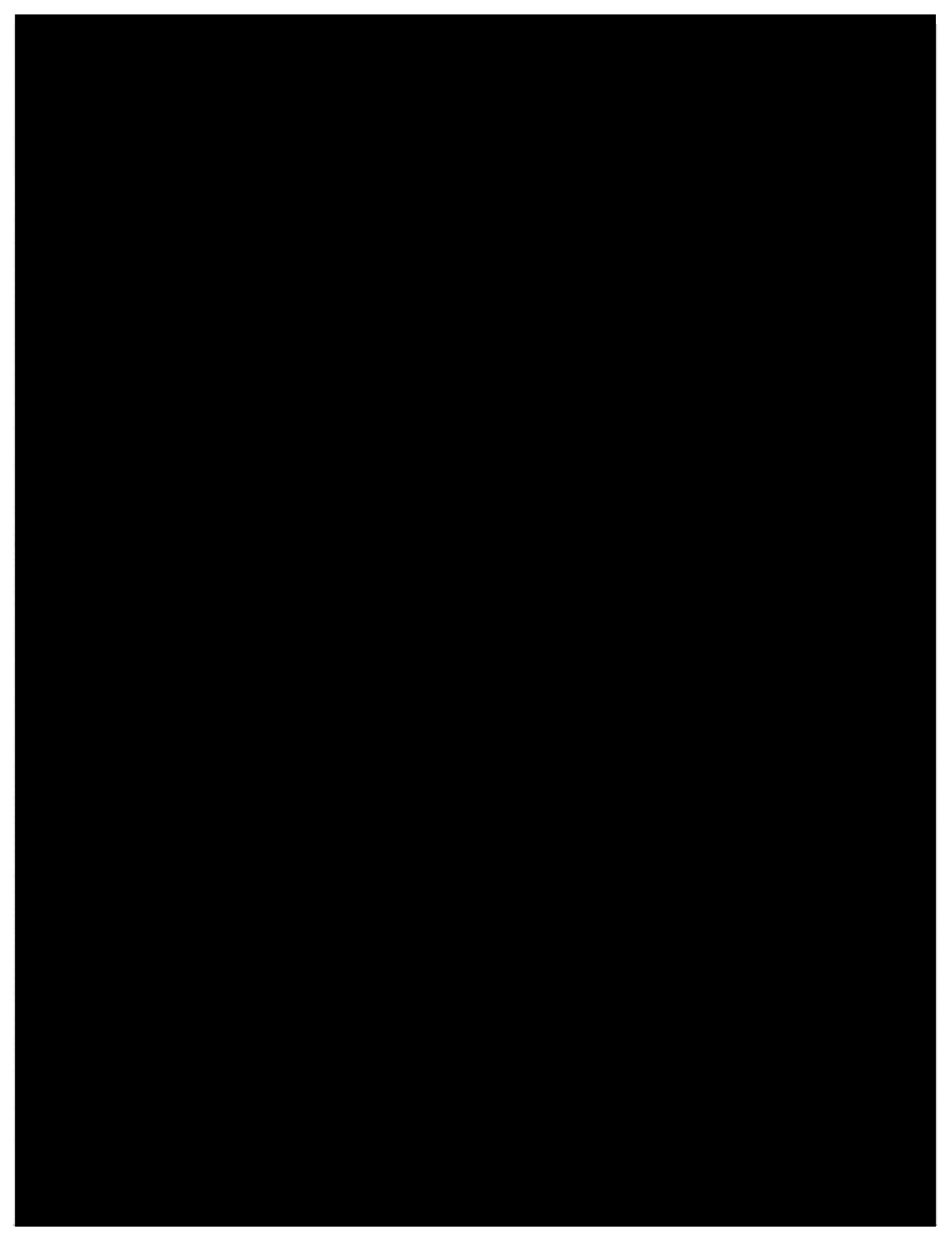

Fig. 8: Sherrie Levine, After Walker Evans: 4, 1981, gelatin silver print, (Metropolitan Museum of Art: New York, NY). 


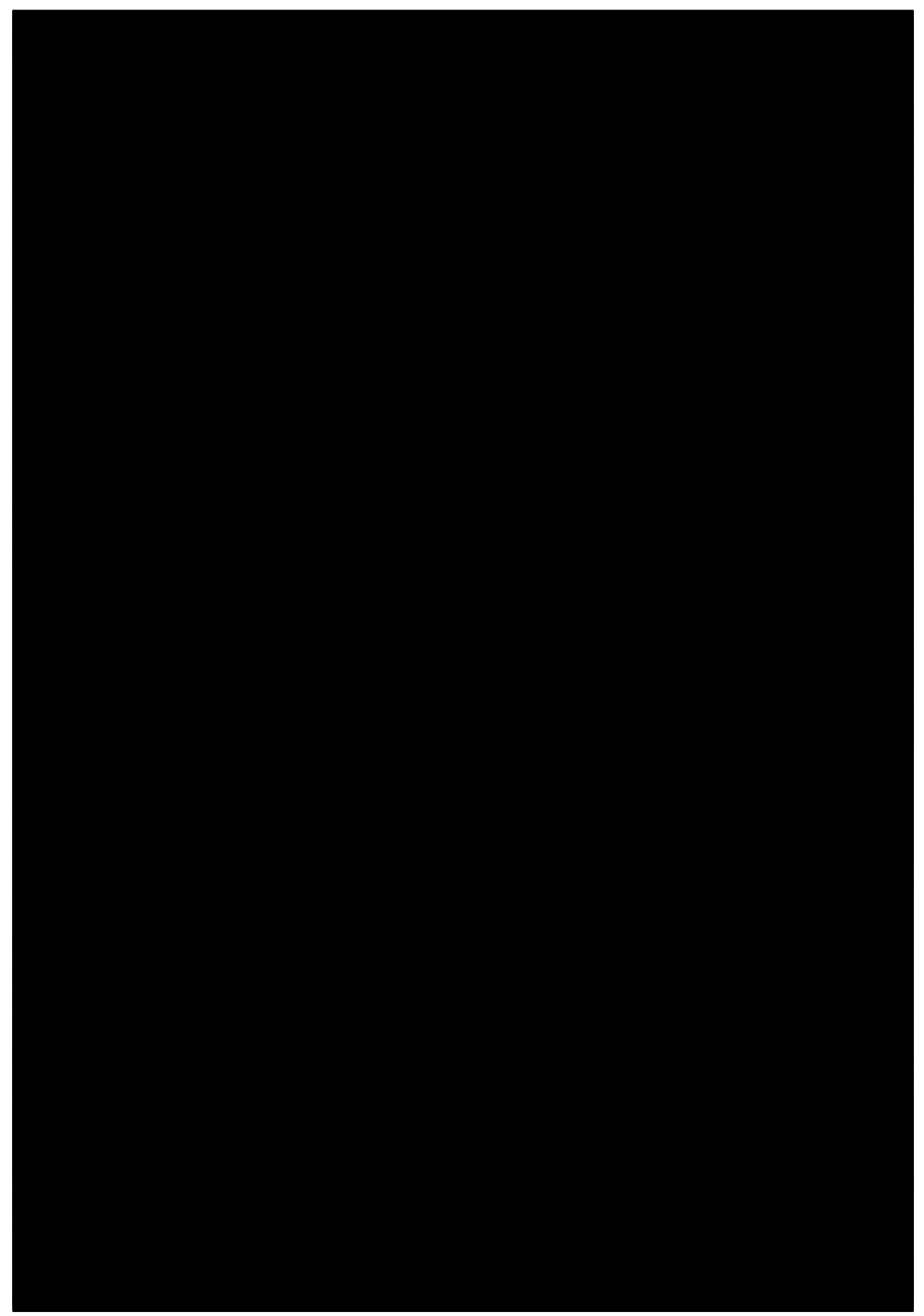

Fig. 9: Walker Evans, Alabama Tenant Farmer Wife, 1936, gelatin silver print, (Metropolitan Museum of Art: New York, NY). 


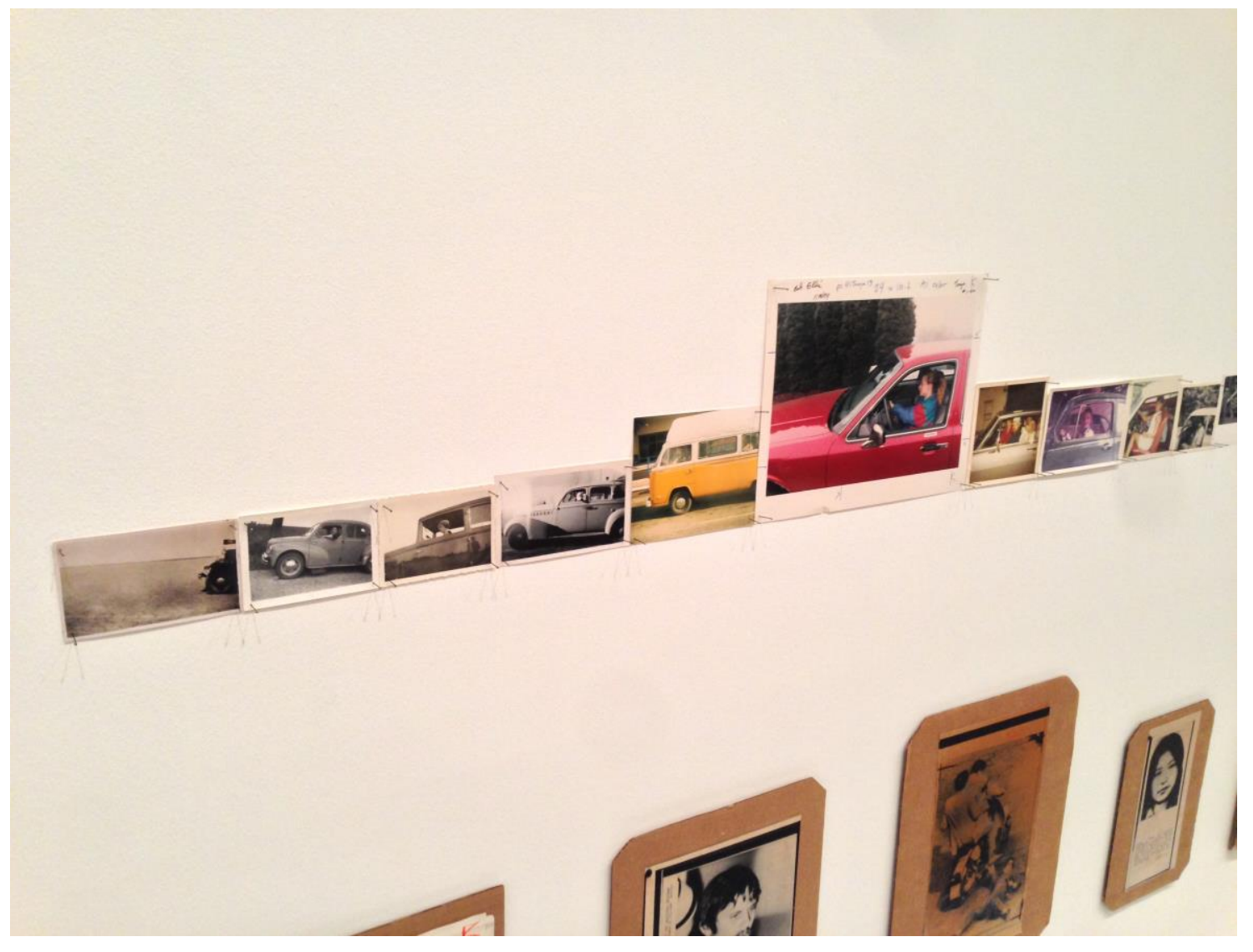

Fig. 10: Detail of Drive by (en passant) at Patrick Pound: The Great Exhibition, May 2017, photograph by author. 


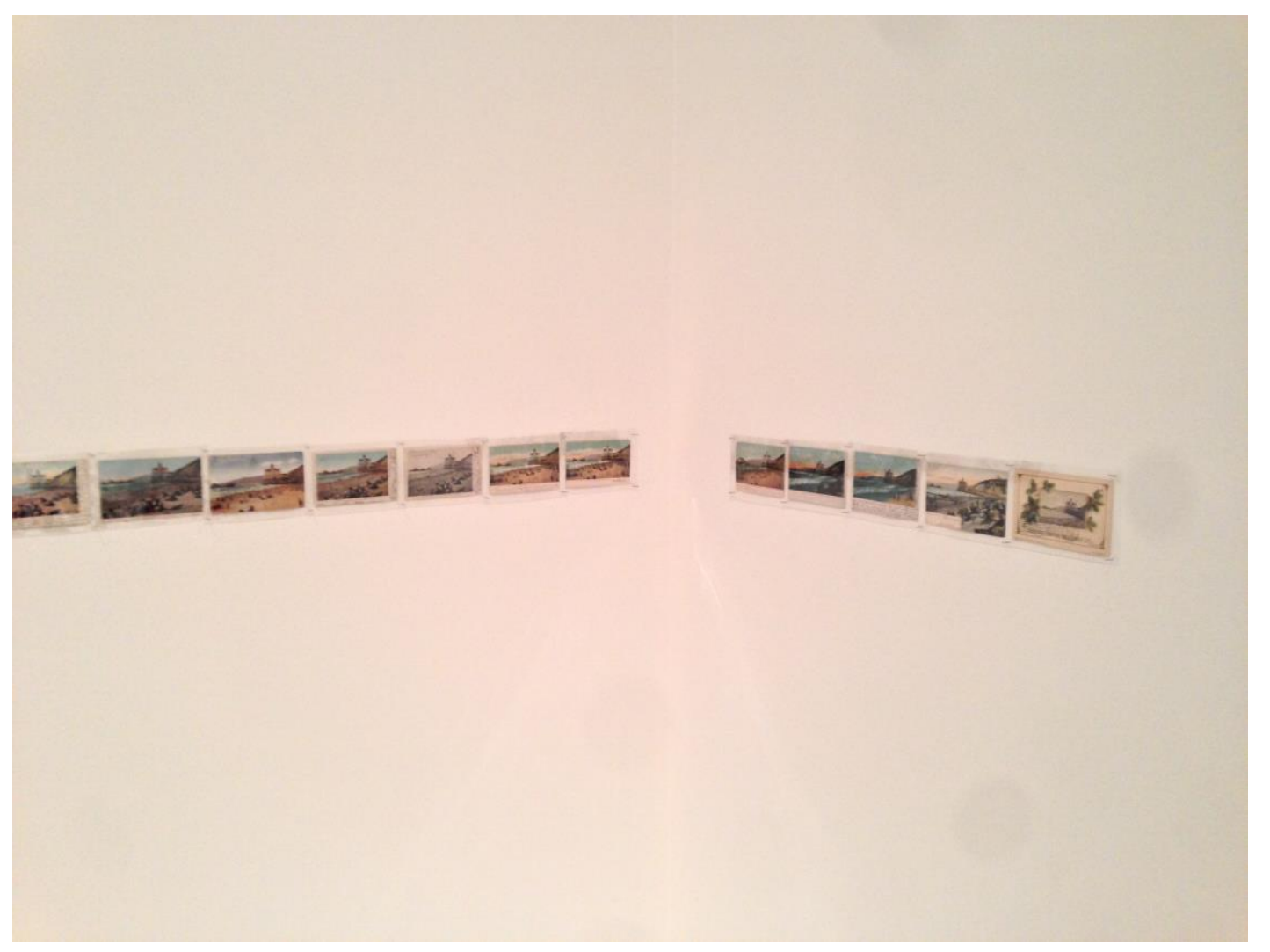

Fig. 11: Detail of The Cliff House at Patrick Pound: The Great Exhibition, May 2017, photograph by author. 


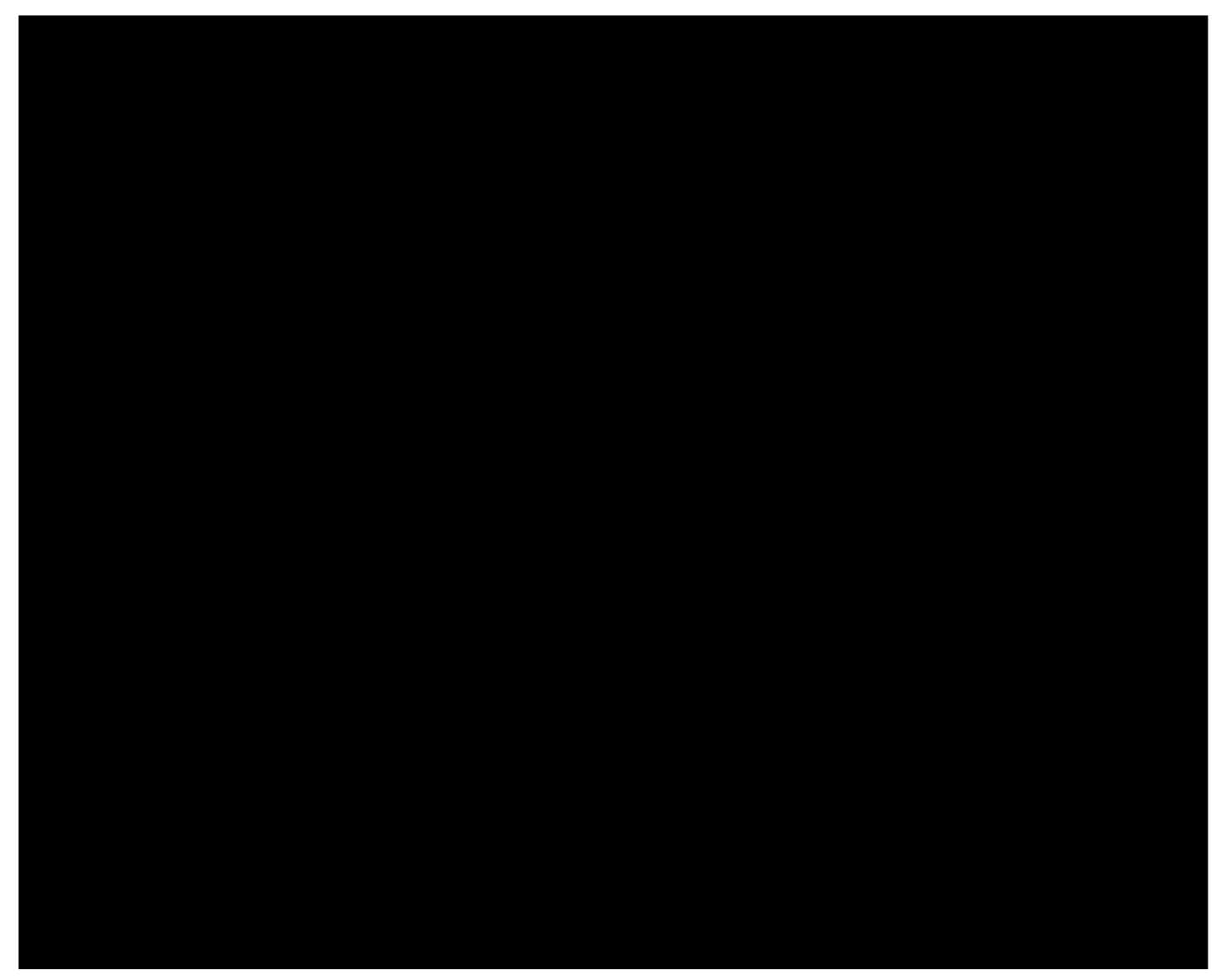

Fig. 12: Patrick Pound, No, 2005, oil paint and books, (Hamish McKay: Wellington, NZ). 


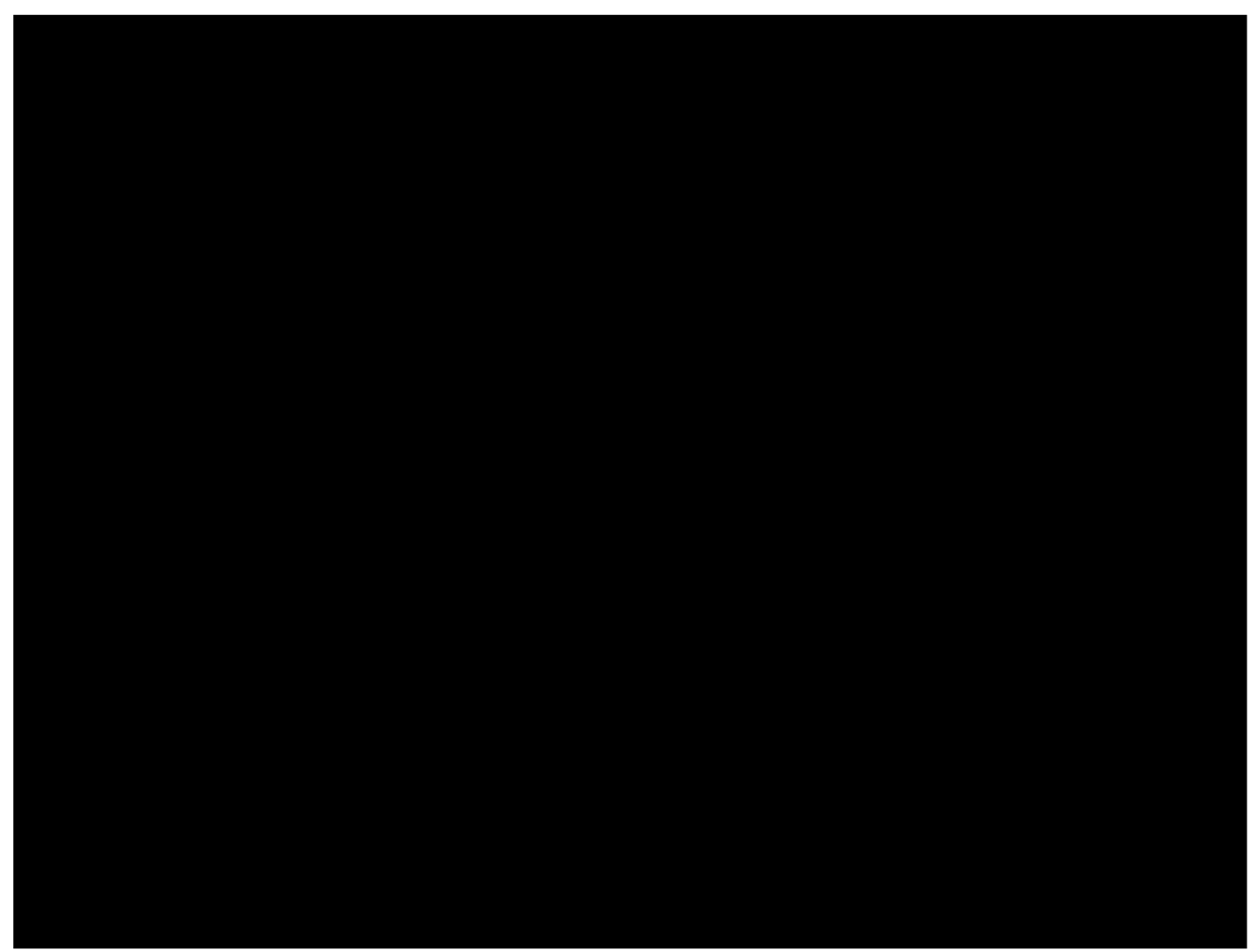

Fig. 13: Patrick Pound, Flinders Notebook, 2007, oil paint on board, (Hamish McKay: Wellington, NZ). 


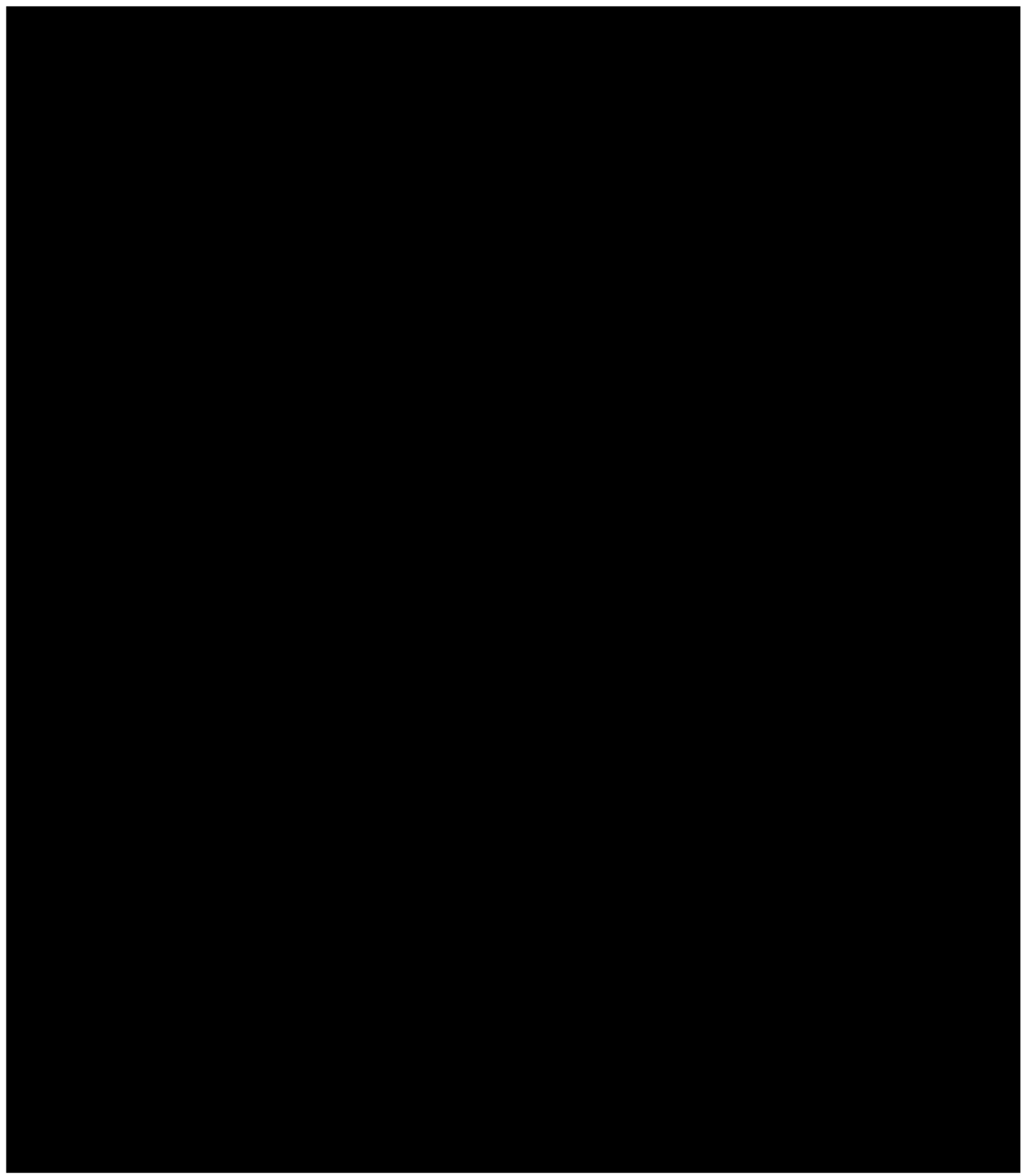

Fig. 14: Robert Rauschenberg, Erased de Kooning Drawing, 1953, paper and gilded frame, (SFMoMA: San Francisco, CA). 


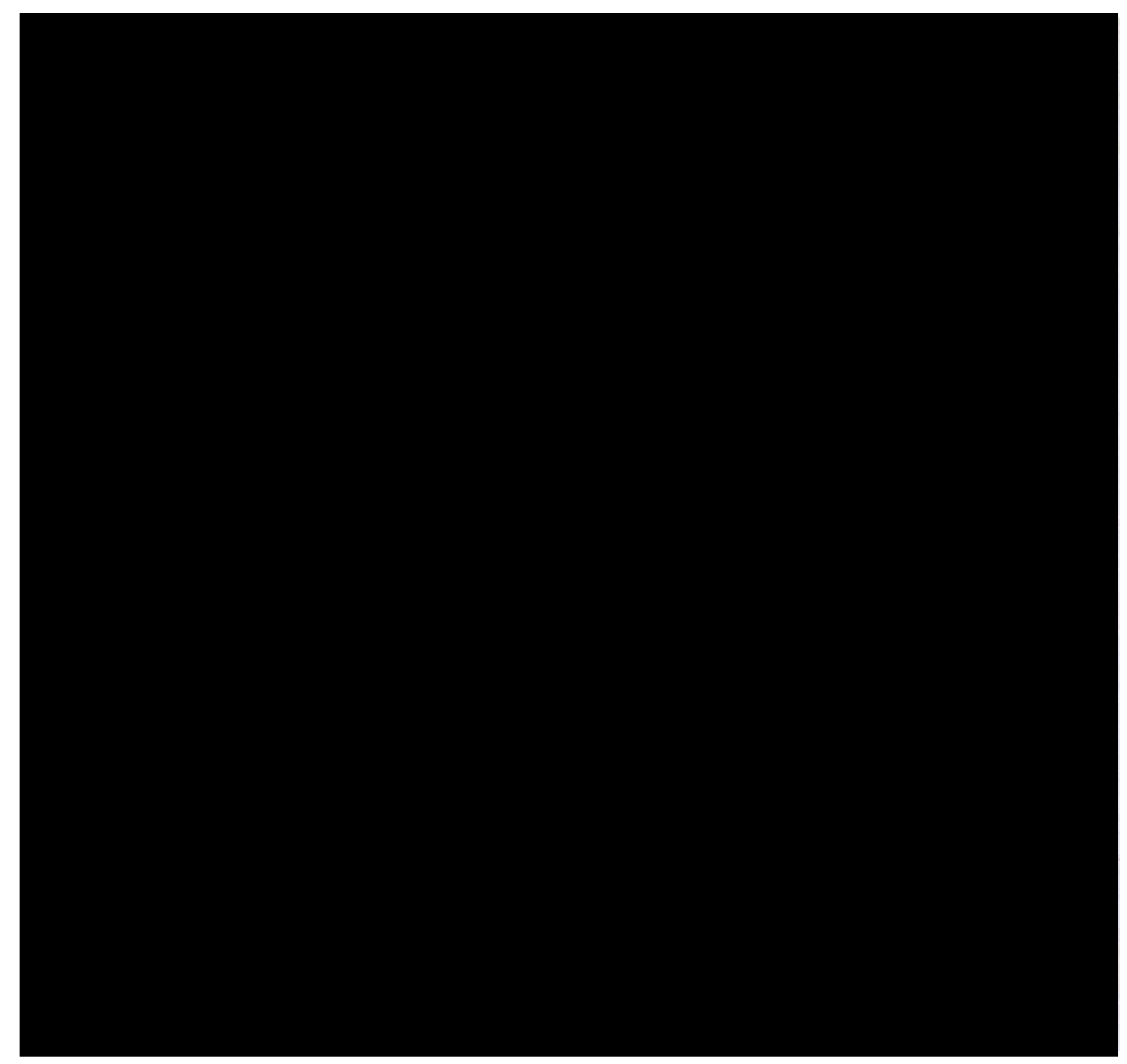

Fig. 15: Kazimir Malevich, Black Square, 1915, oil paint on linen, (Tretyakov Gallery, Moscow). 


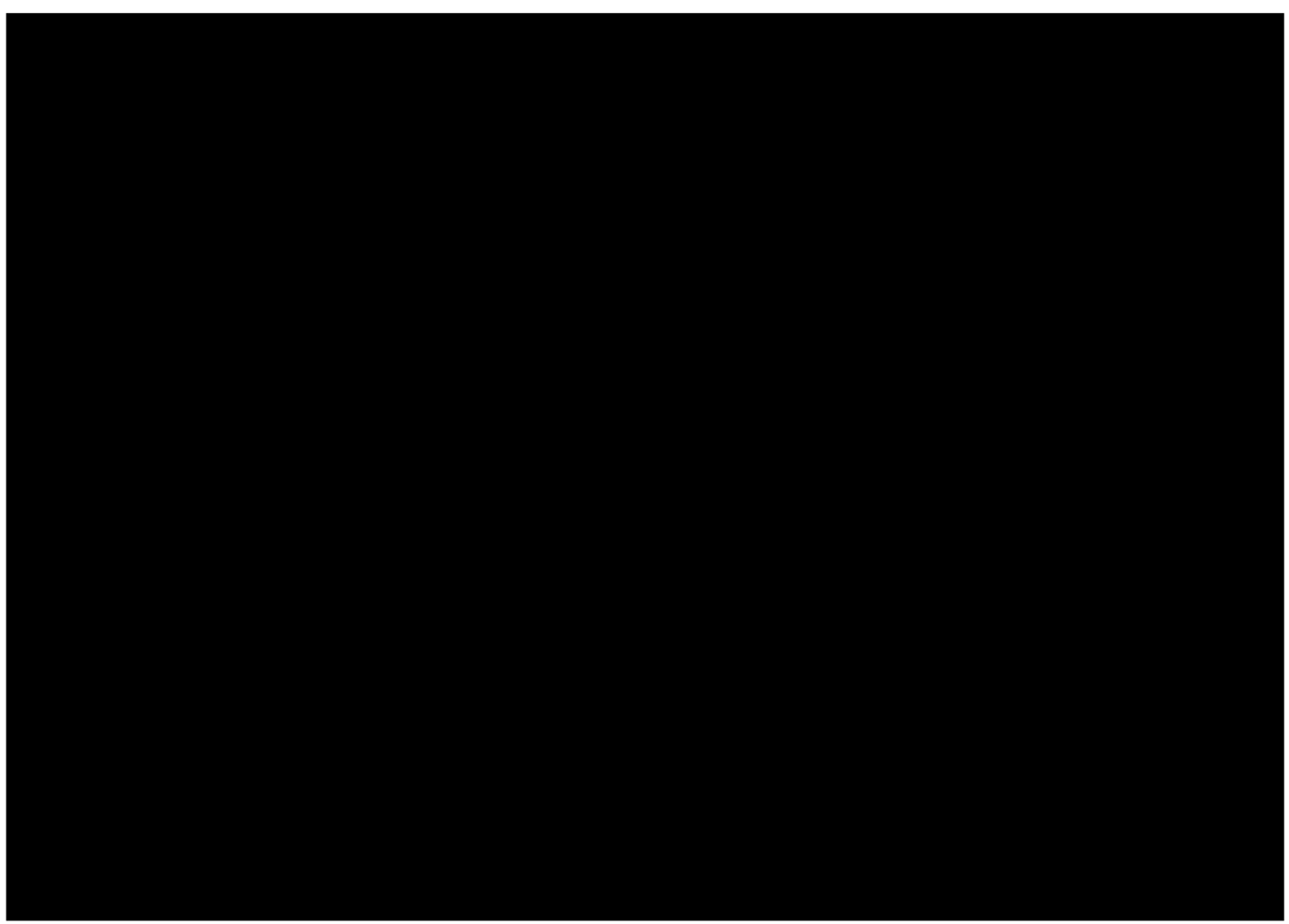

Fig. 16: Ian Burn, 'Value Added' Landscape no. 11, 1993, oil paint on board with perspex, (AGNSW: Sydney, Australia). 


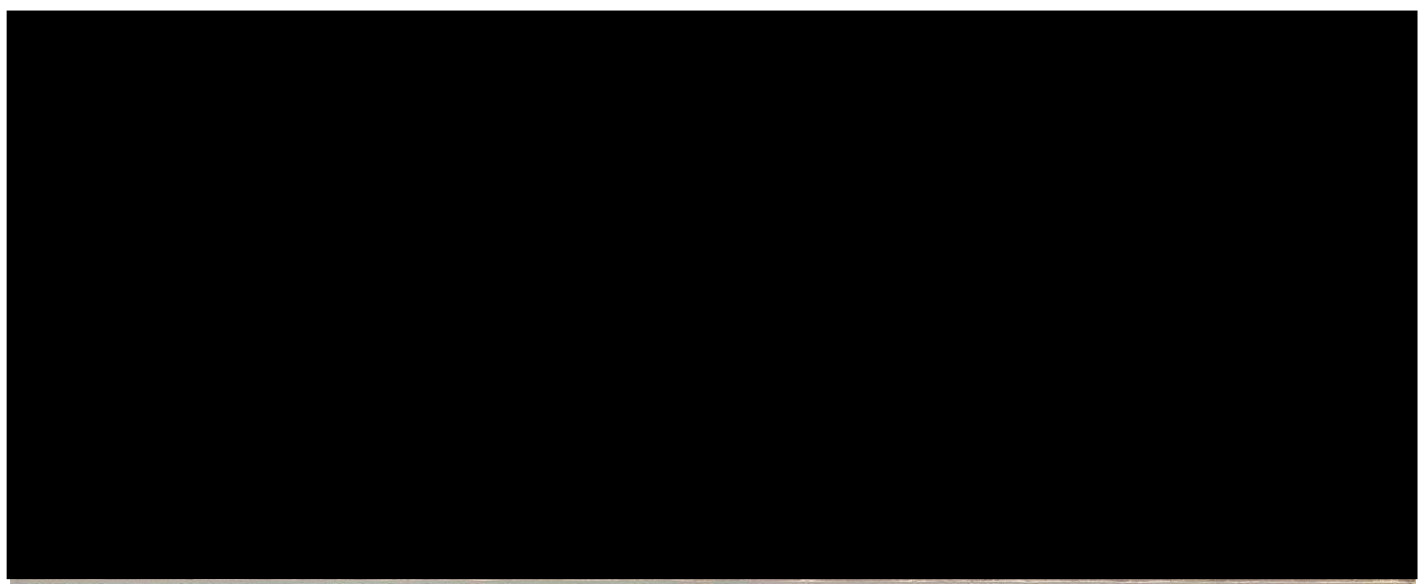

Fig. 17: John Brack, The car, 1955, oil paint on canvas, (NGV: Melbourne, Australia). 


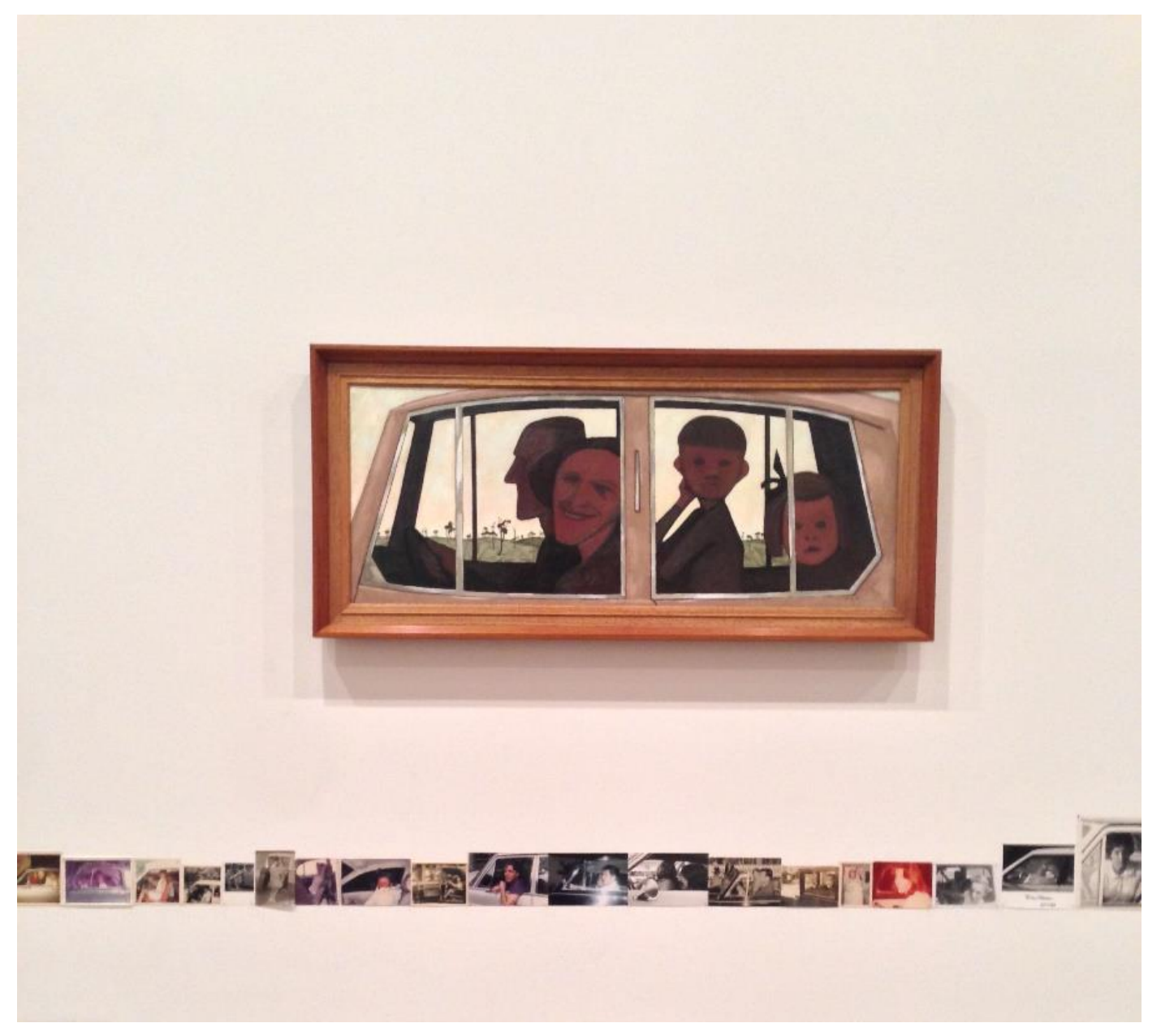

Fig. 18: Detail of John Brack's The car with Drive by (en passant) at Patrick Pound: The Great Exhibition, May 2017, photograph by author. 


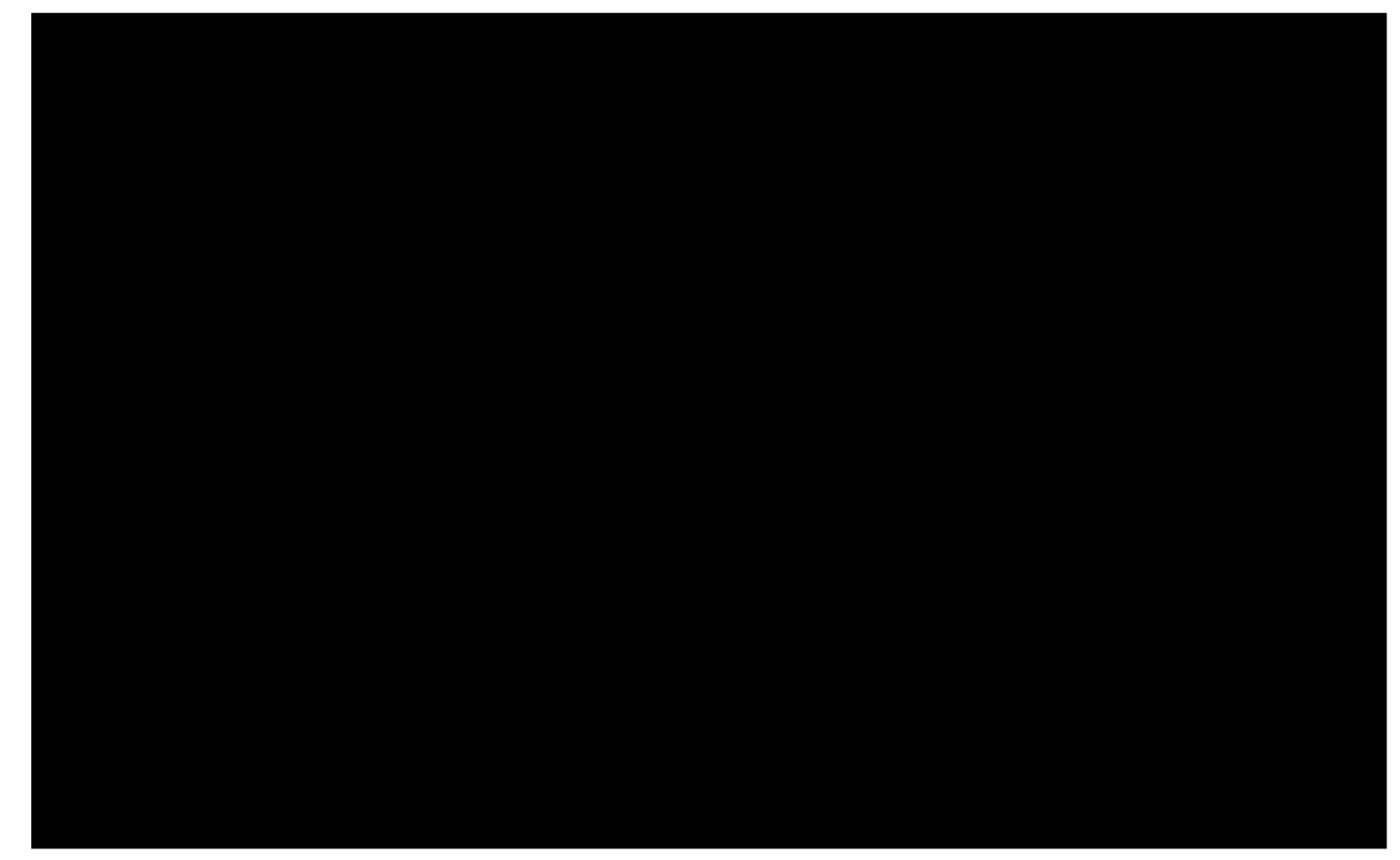

Fig. 19: Still from Orson Welles, François Reichenbach, Gary Graver, and Oja Kodar (dirs.). F for Fake (Germany, Planfilm, 1973), Blu-Ray. 


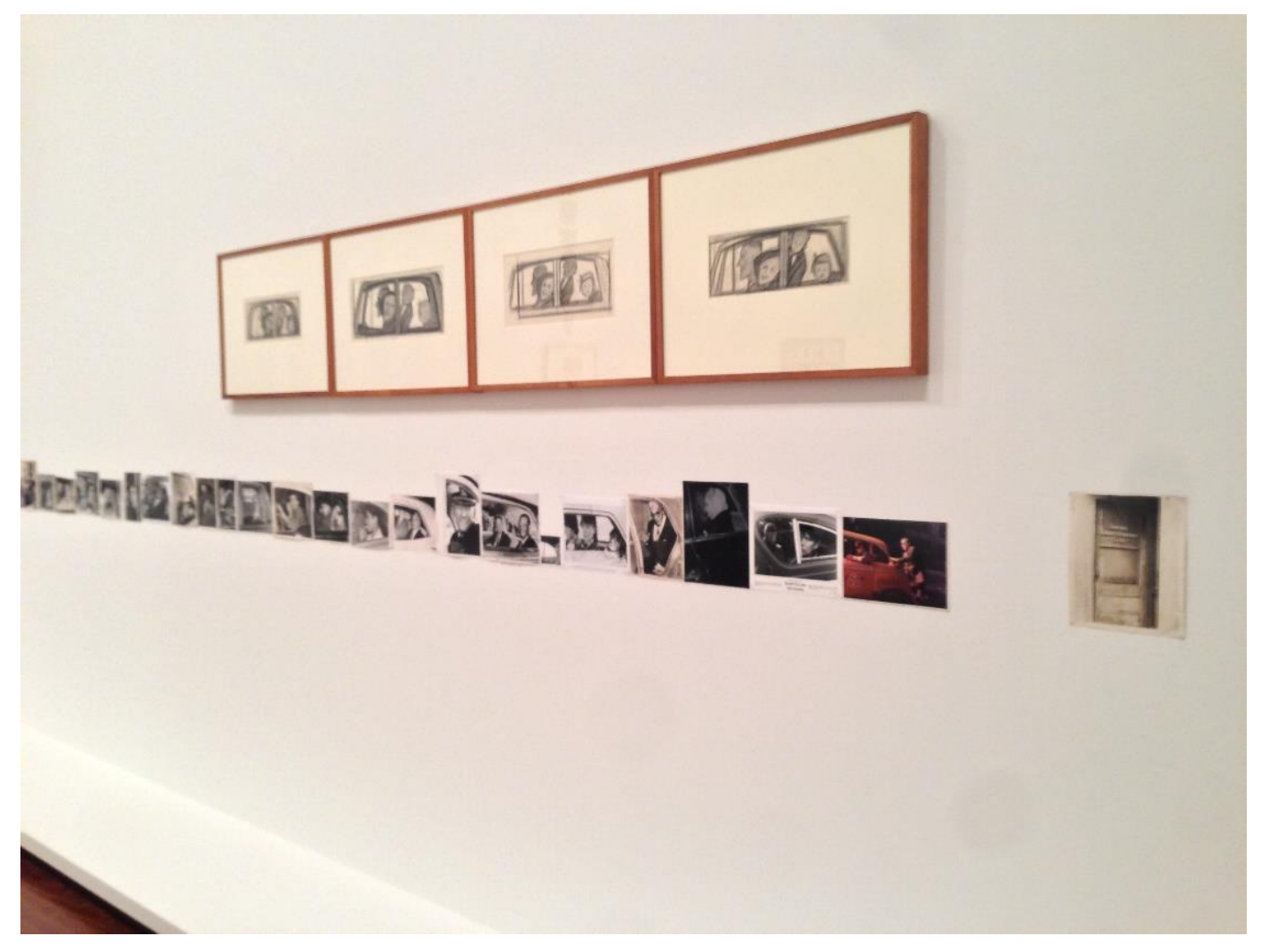

Fig. 20: Detail of John Brack's four (Study for The car) with Drive by (en passant) at Patrick Pound: The Great Exhibition, May 2017, photograph by author. 


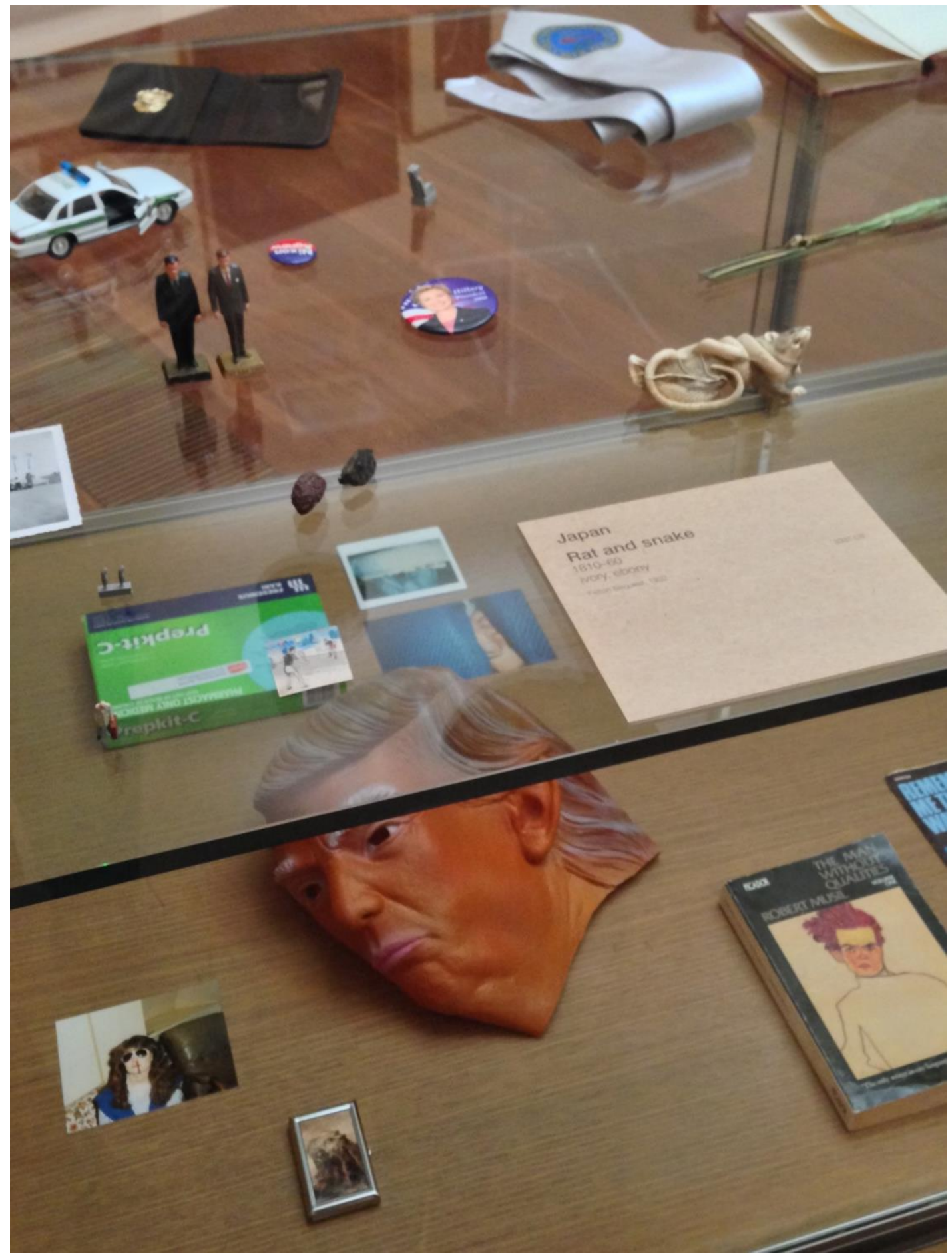

Fig. 21: Detail of The Museum of There / Not there at Patrick Pound: The Great Exhibition, May 2017, photograph by author. 


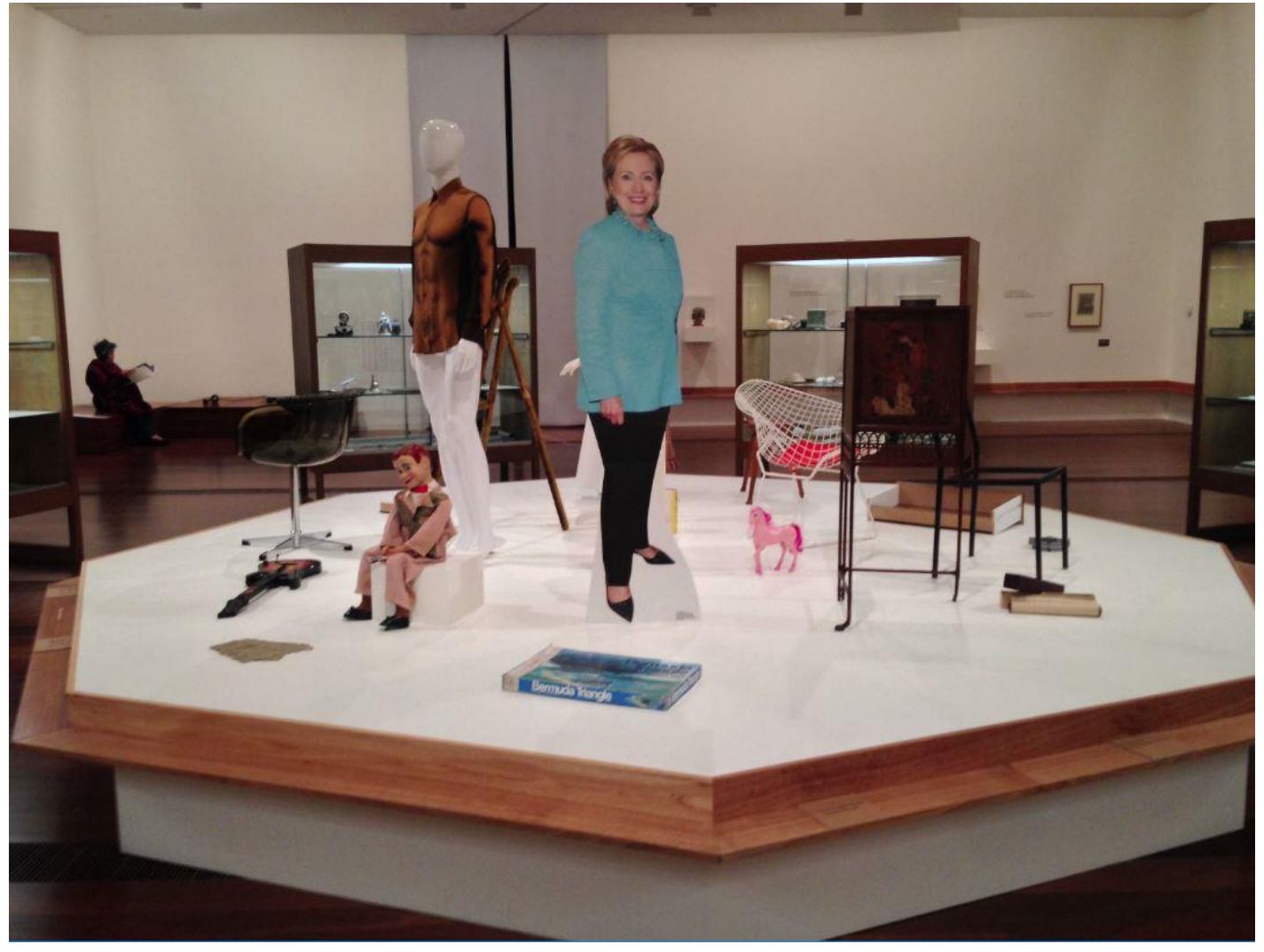

Fig. 22: Detail of The Museum of There / Not there at Patrick Pound: The Great Exhibition, May 2017, photograph by author. 


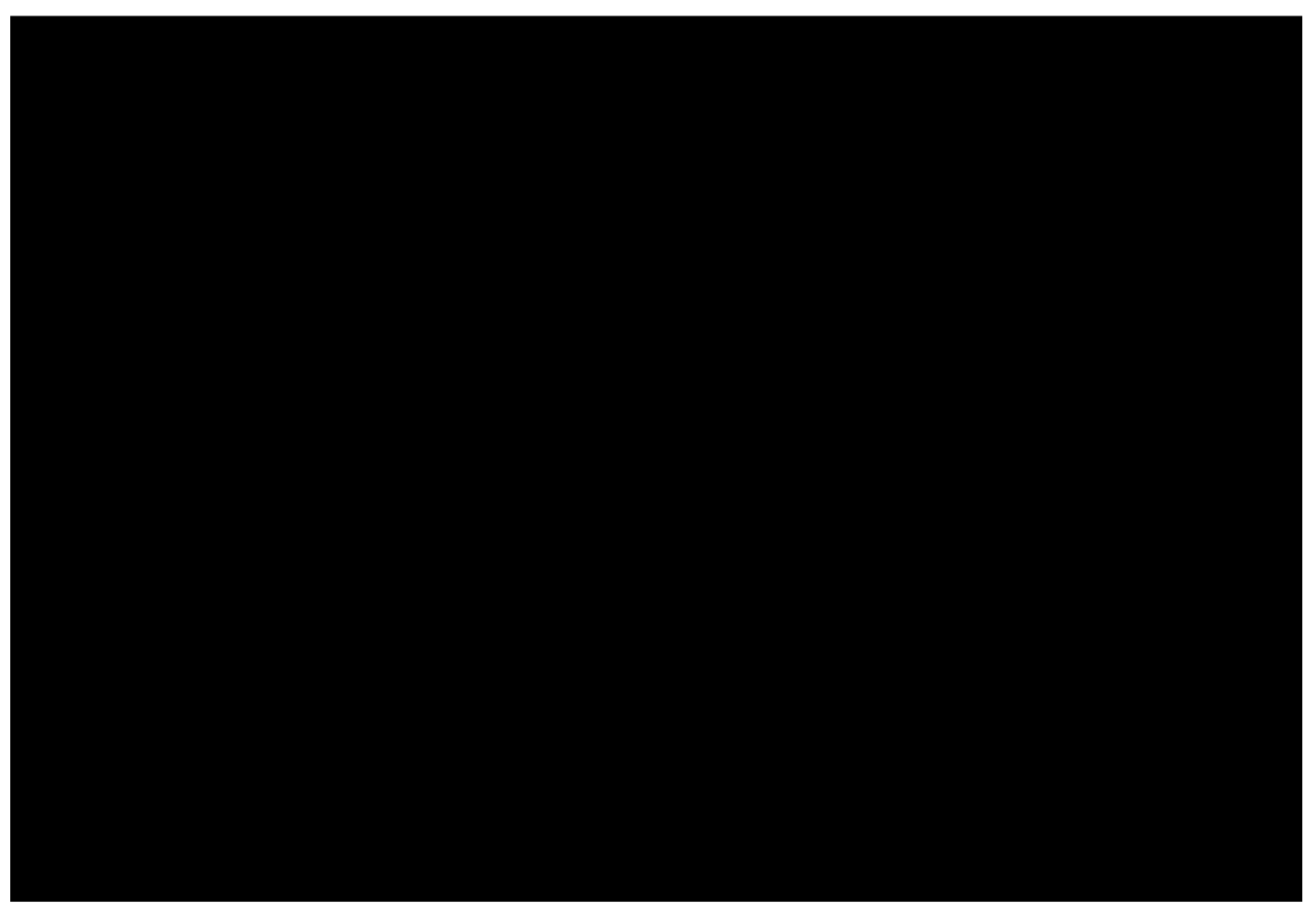

Fig. 23: David Moore, Migrants arriving in Sydney, 1966, gelatin silver print, (NGV: Melbourne, Australia). 


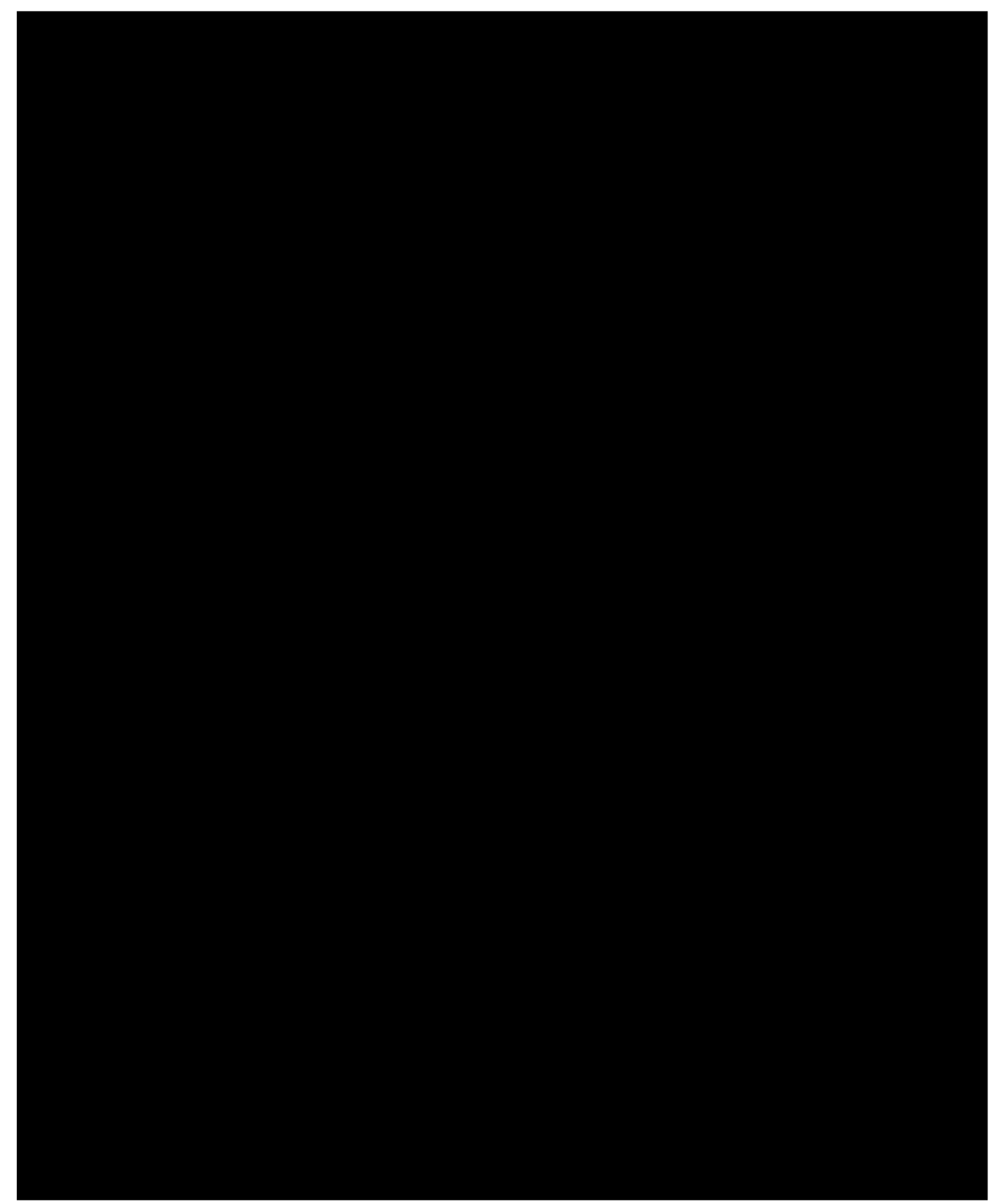

Fig. 24: Alfred Stieglitz, The steerage. 1907 [printed 1911], photogravure, (NGV: Melbourne, Australia). 


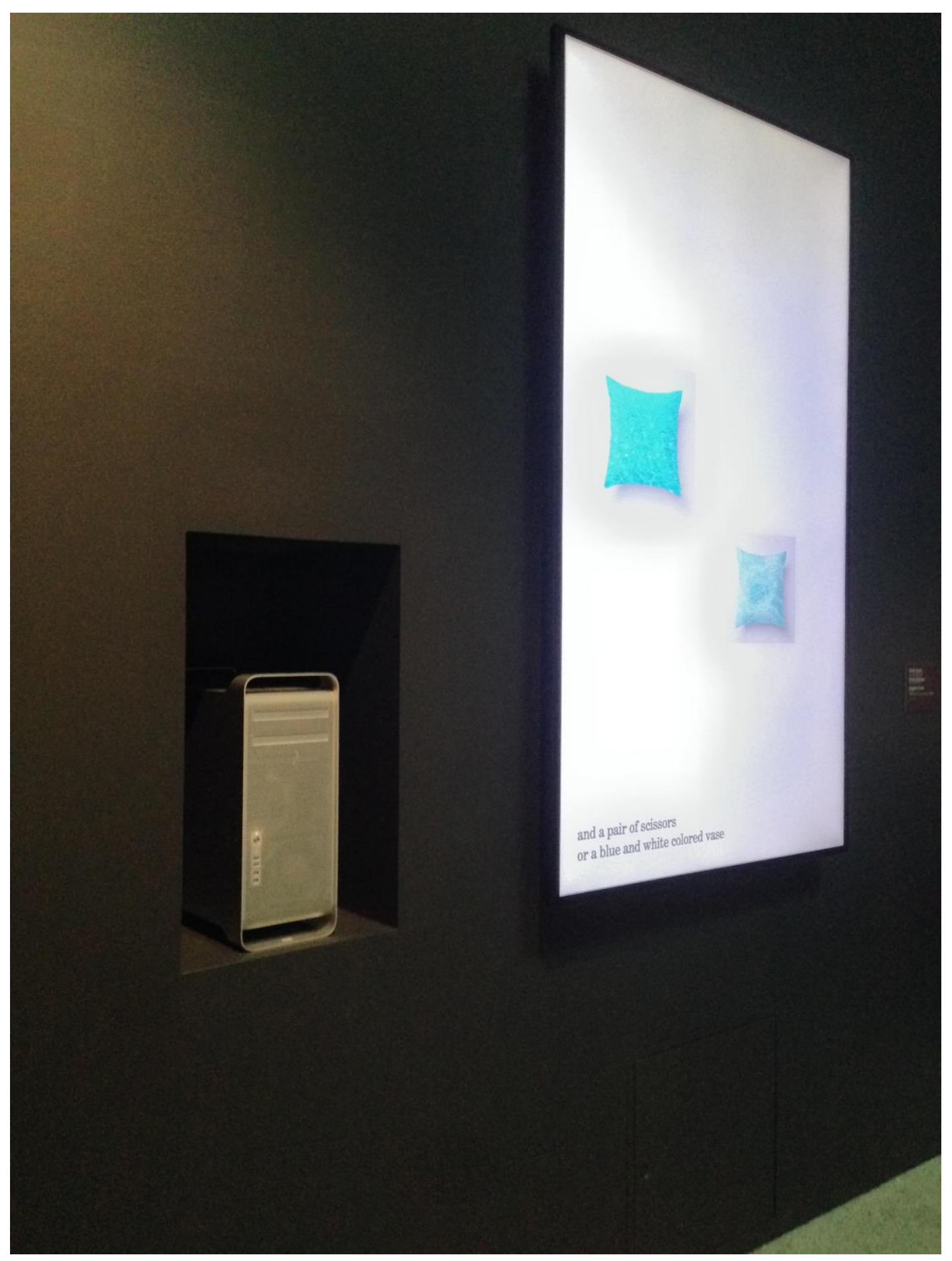

Fig. 25: Detail of Rowan McNaught and Patrick Pound's Thoughts-of-sorts at Patrick Pound: The Great Exhibition, May 2017, photograph by author. 


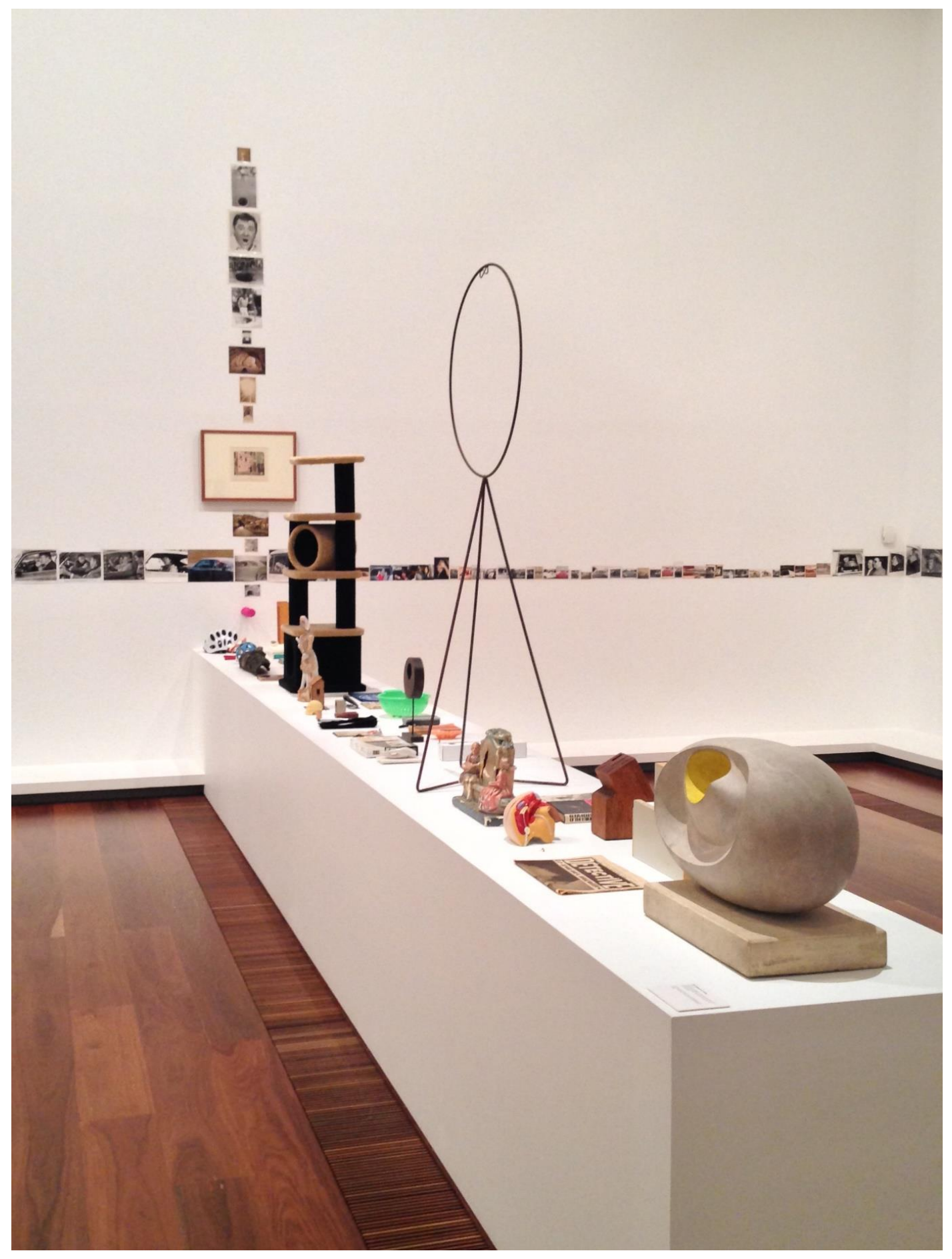

Fig. 26: Detail of 'wheel' in The Museum of holes at Patrick Pound: The Great Exhibition, May 2017, photograph by author. 


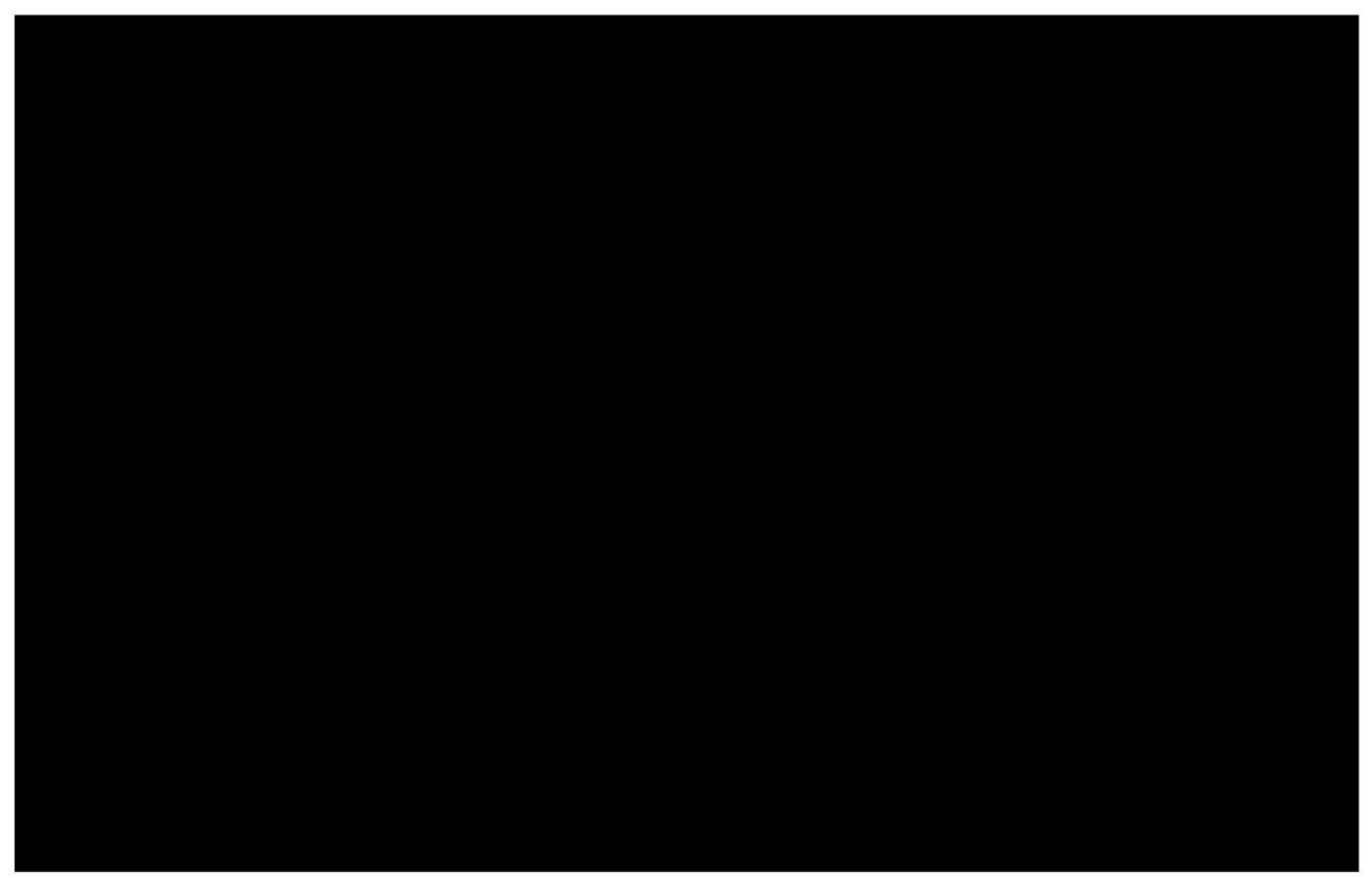

Fig. 27: Detail of The photographer's shadow at Patrick Pound: The Great Exhibition, 2017, photograph by Wayne Taylor. Retrieved from https://artblart.com /2017/07/26/review-patrick-pound-the-great-exhibition-at-ngv-australiamelbourne-part-2/. Accessed 30 July 2018. 


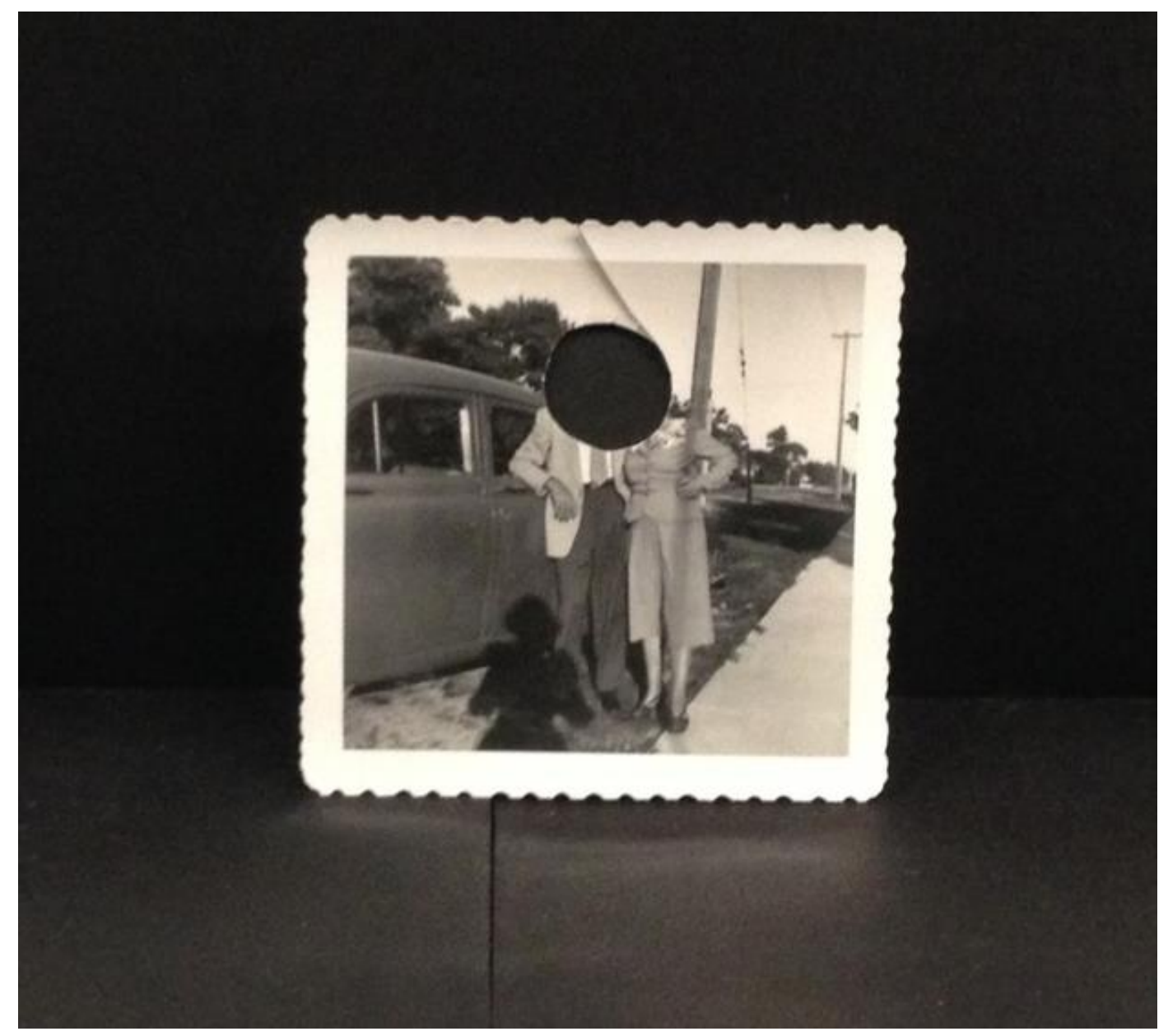

Fig. 28: Detail from The photographer's shadow at Patrick Pound: The Great Exhibition, May 2017, photograph by author. 


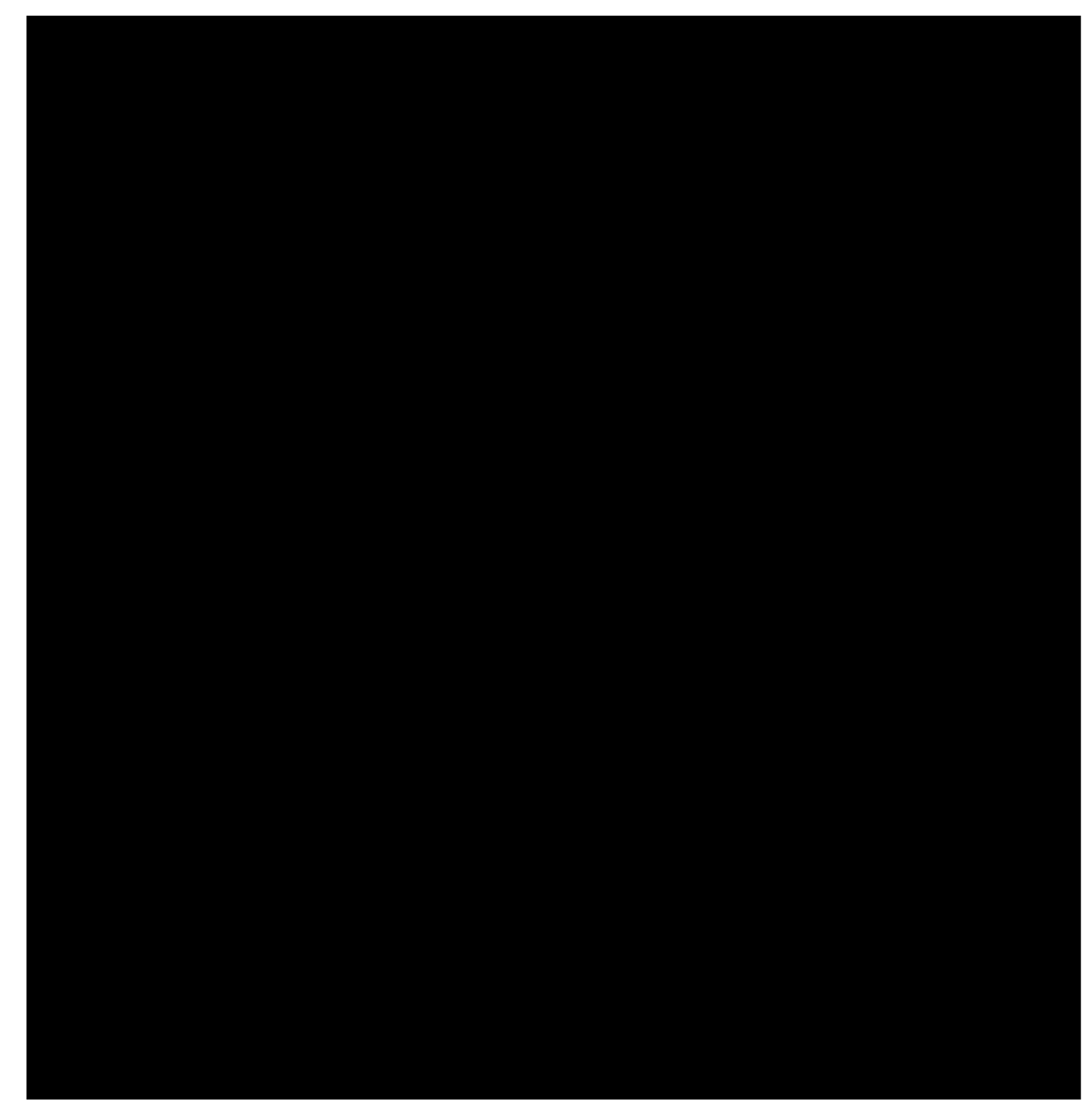

Fig. 29: Detail from The hand of the photographer at Patrick Pound: The Great Exhibition. Retrieved from https://www.ngv.vic.gov.au/exhibition/patrick-pound/. Accessed 30 July 2018. 


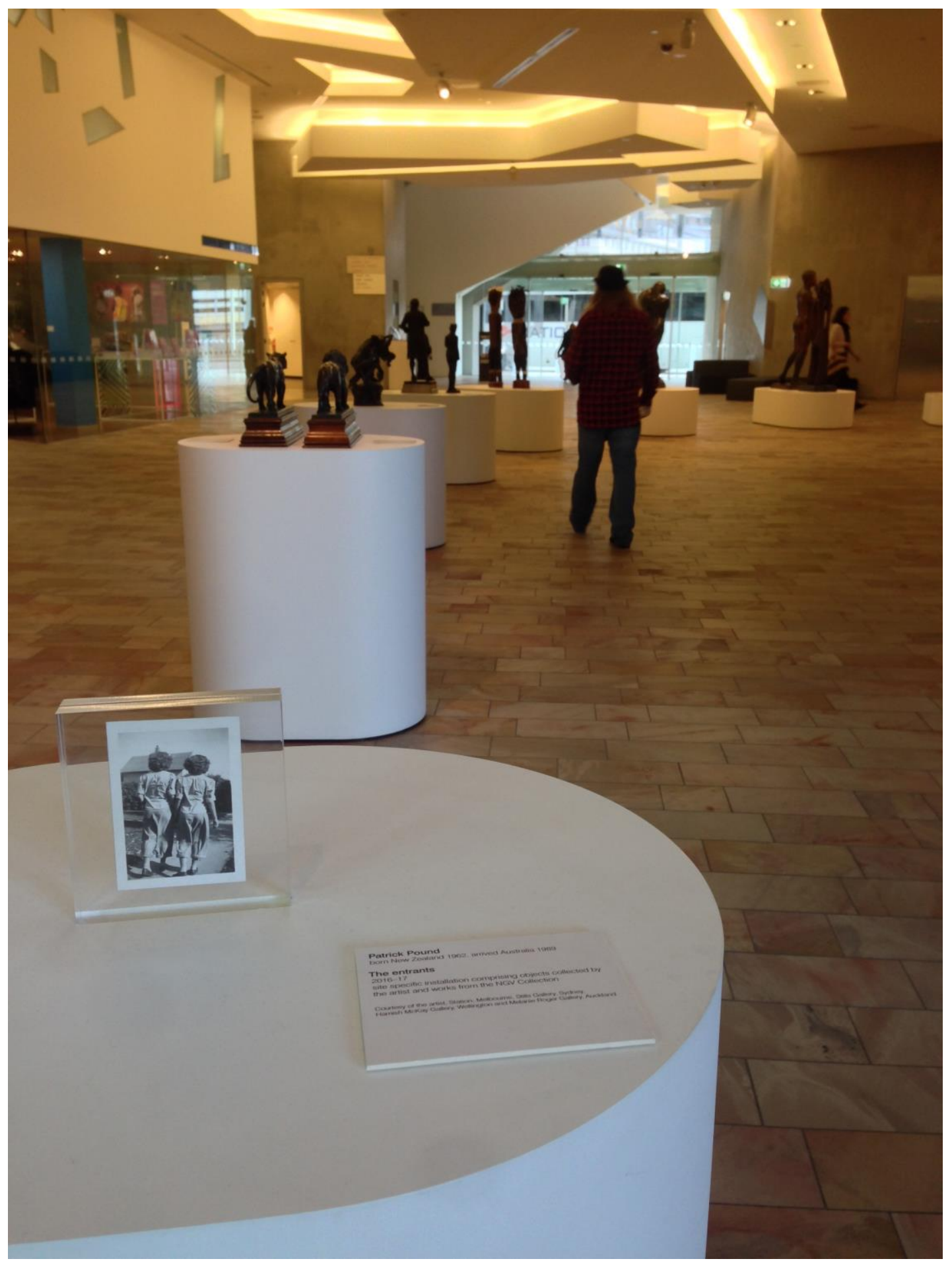

Fig. 30: Detail of The entrants from foyer of NGV at entrance of Patrick Pound: The Great Exhibition, May 2017, photograph by author. 


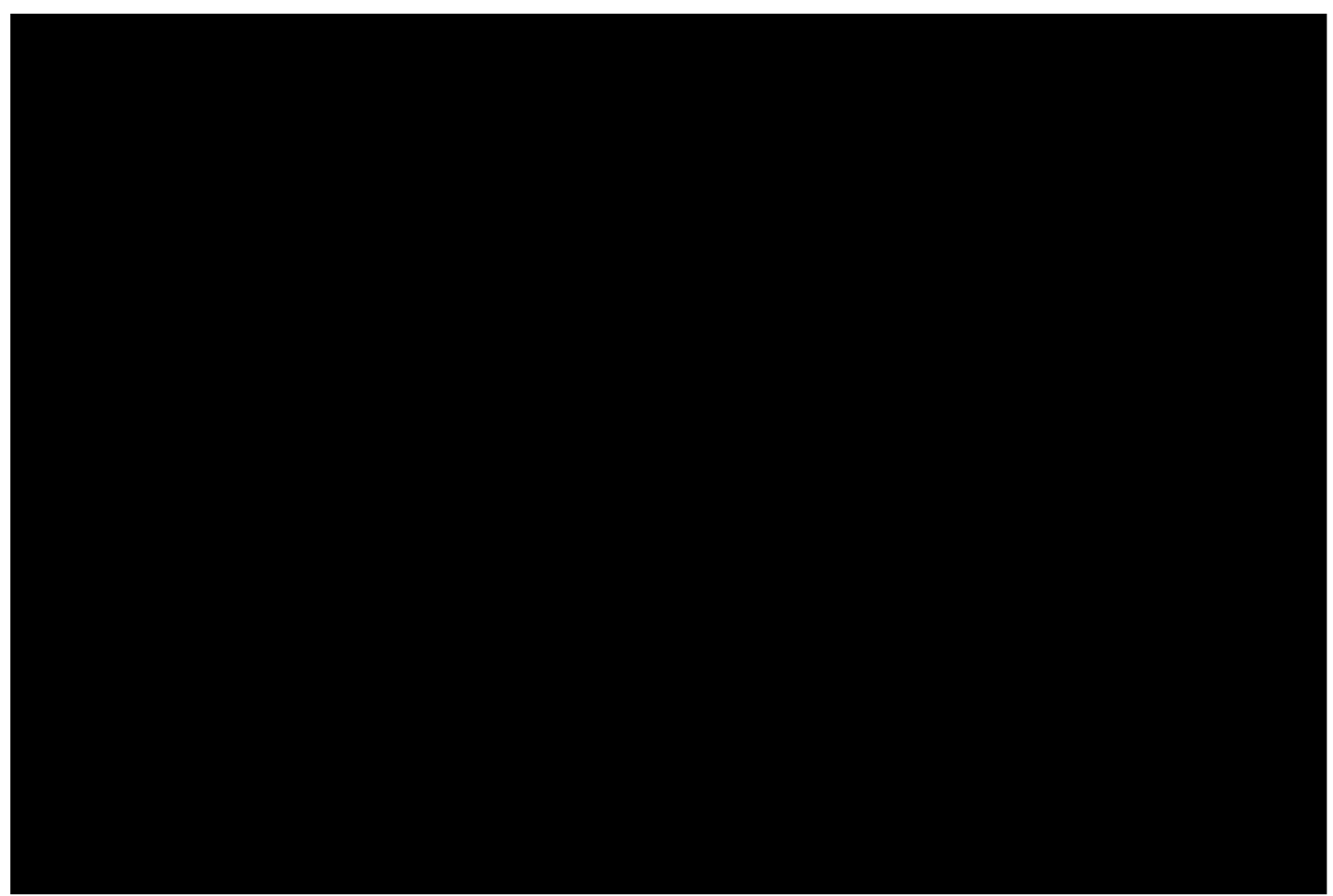

Fig. 31: Installation shot of The sleeping gallery at Patrick Pound: The Great Exhibition, 2017, photograph by Wayne Taylor. Retrieved from

https://artblart.com/2017/07/26/review-patrick-pound-the-great-exhibition-at-ngvaustralia-melbourne-part-2/. Accessed 30 July 2018. 


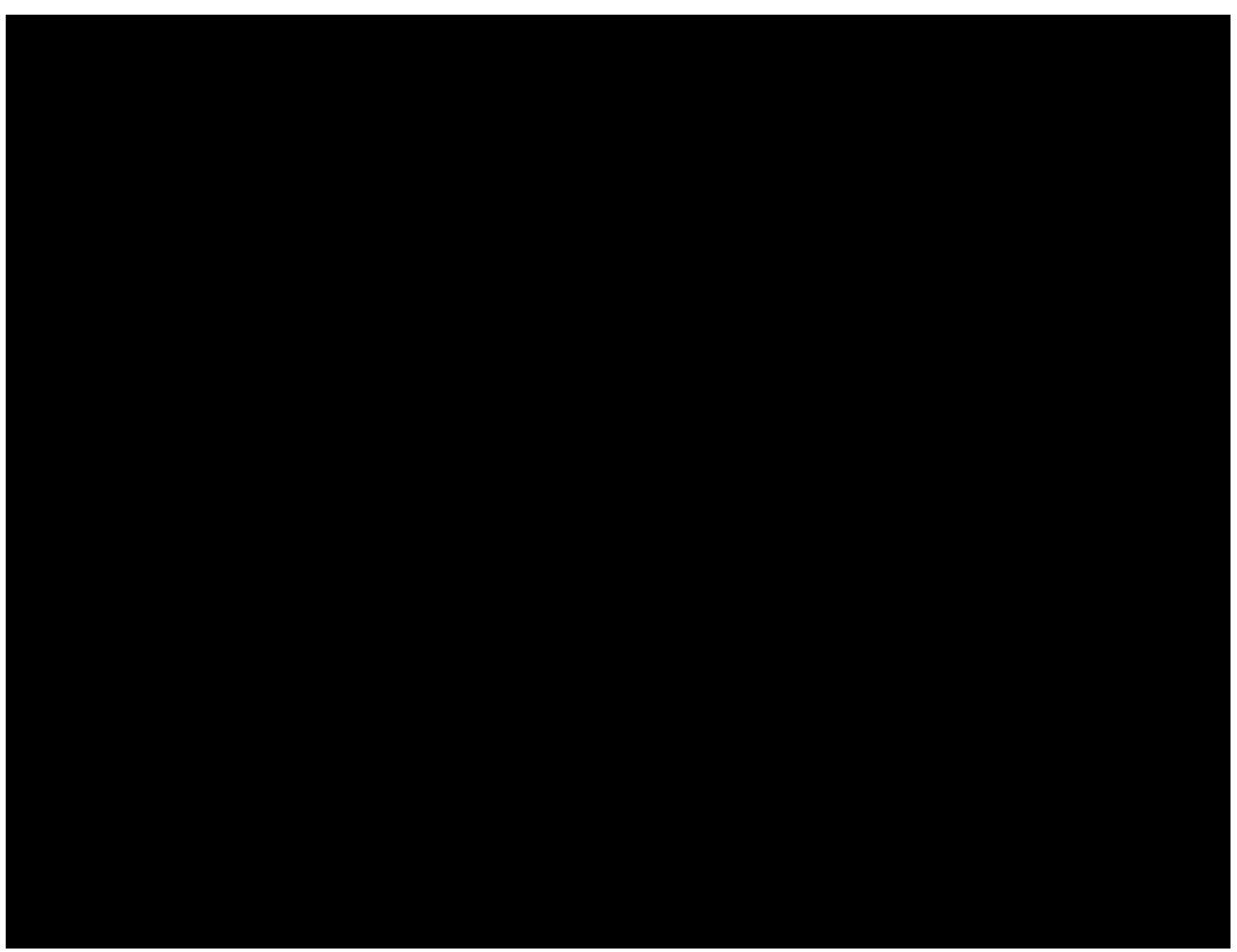

Fig. 32: Detail from Damaged at Patrick Pound: The Great Exhibition. Retrieved from https://www.ngv.vic.gov.au/exhibition/patrick-pound/. Accessed 30 July 2018. 


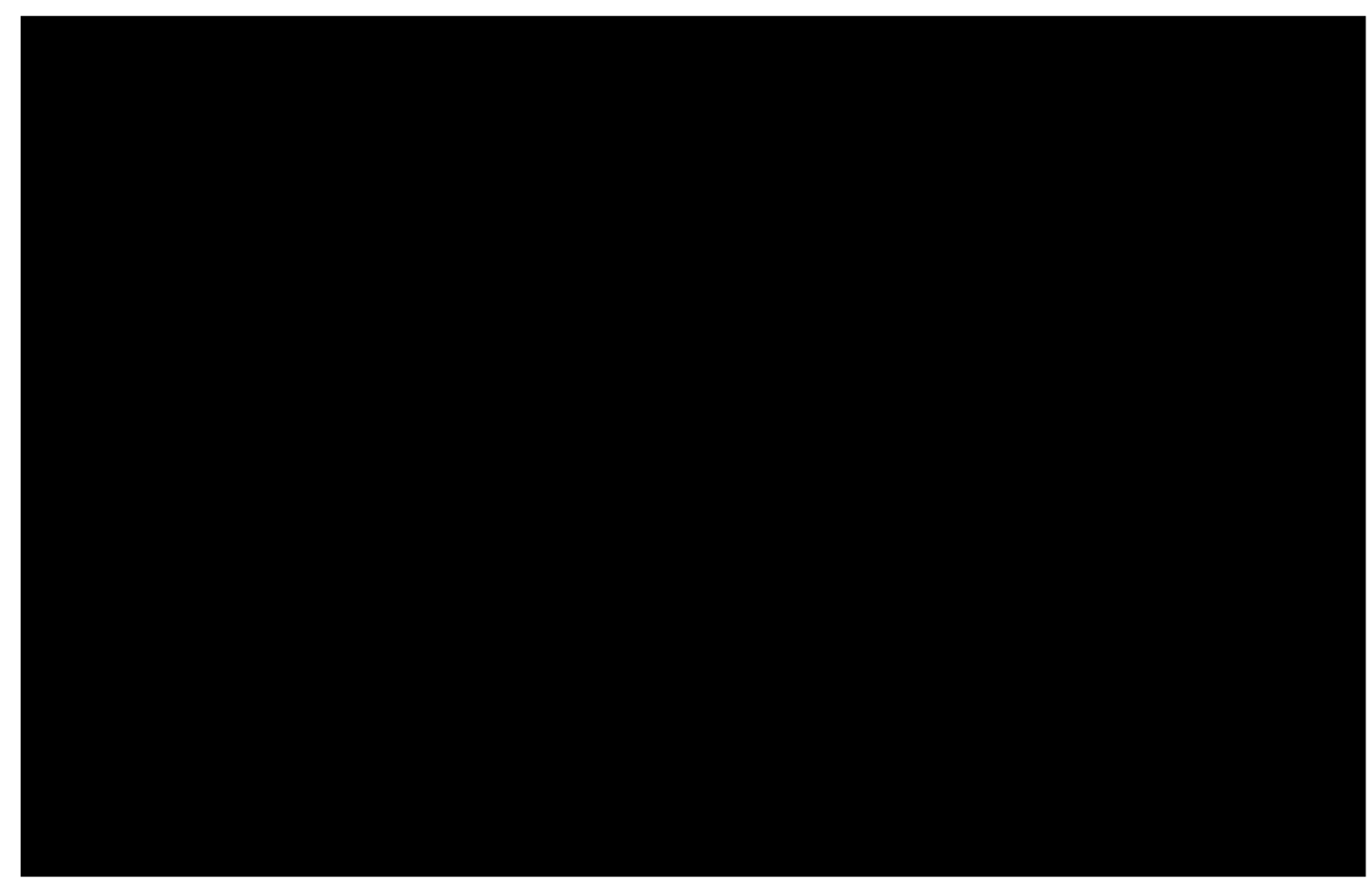

Fig: 33: Erik Kessels, 24 Hours in Photos, 2011, multimedia, installation staged December 2011 - January 2012 at FOAM: Amsterdam, Holland. Retrieved from http://www.kesselskramer.com/exhibitions/24-hrs-of-photos. Accessed 30 July 2018. 


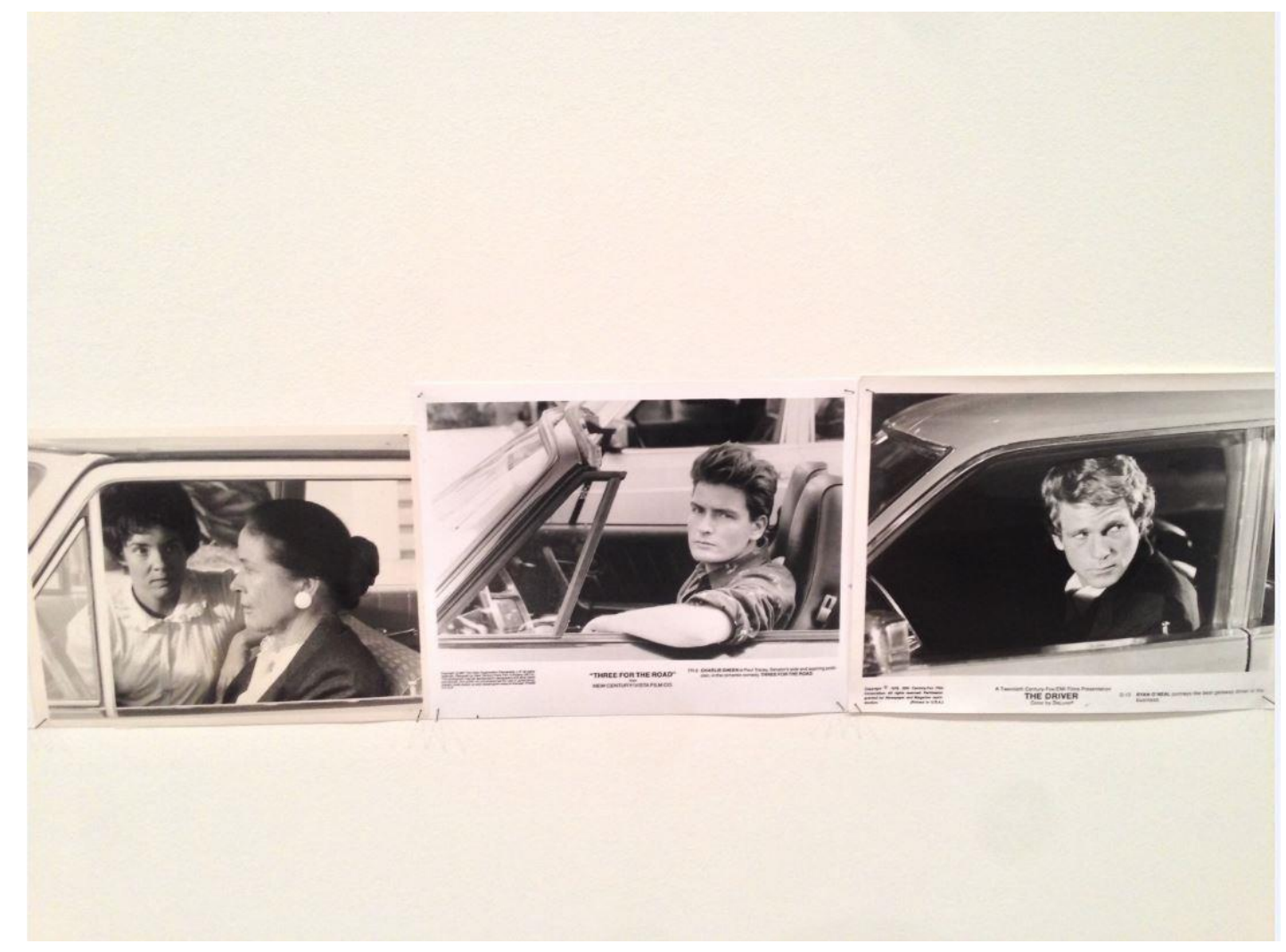

Fig. 34: Detail of Charlie Sheen in Drive by (en passant) at Patrick Pound: The Great Exhibition, May 2017, photograph by author. 


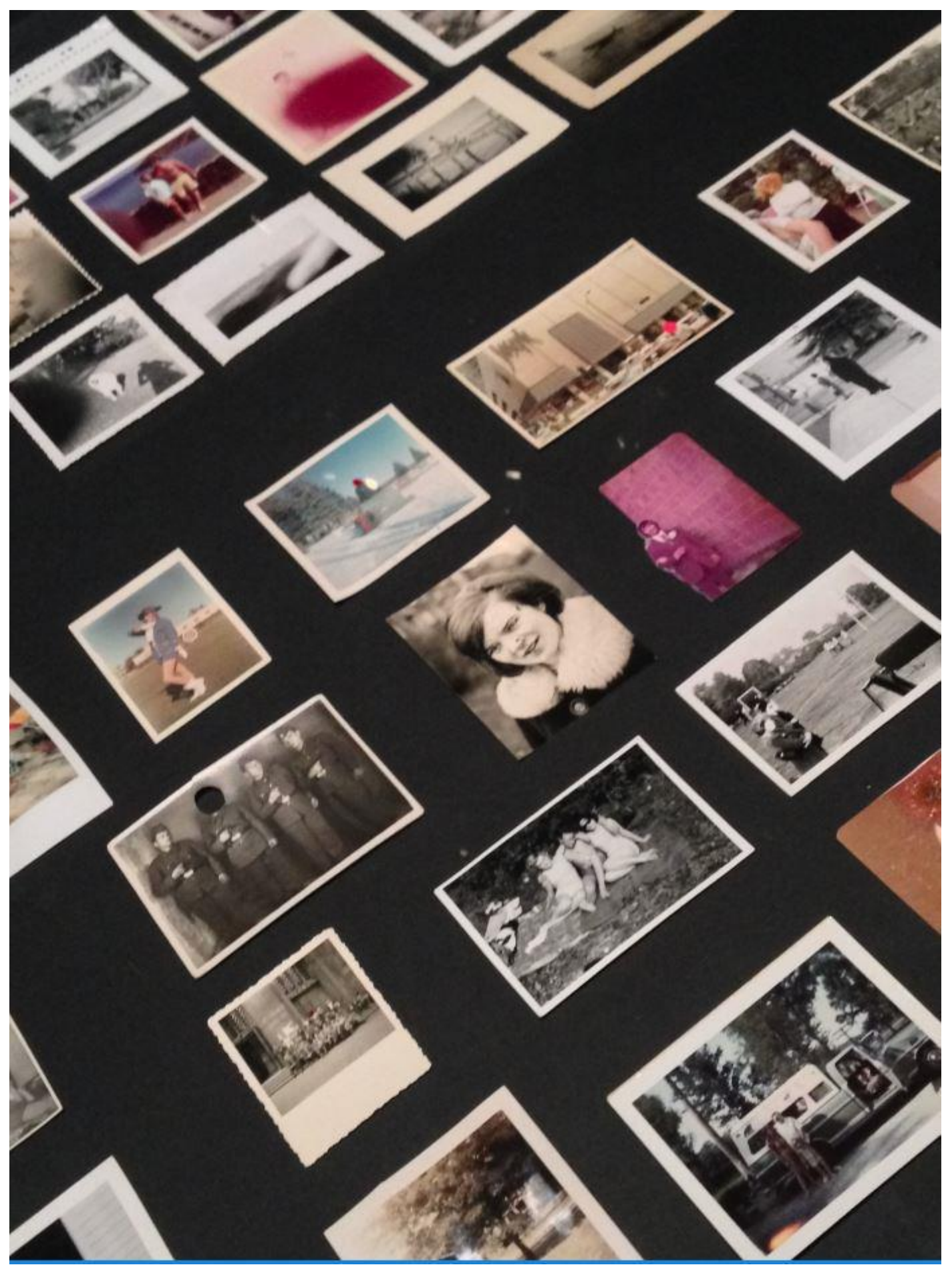

Fig. 35: Detail from Damaged at Patrick Pound: The Great Exhibition, May 2017, photograph by author. 


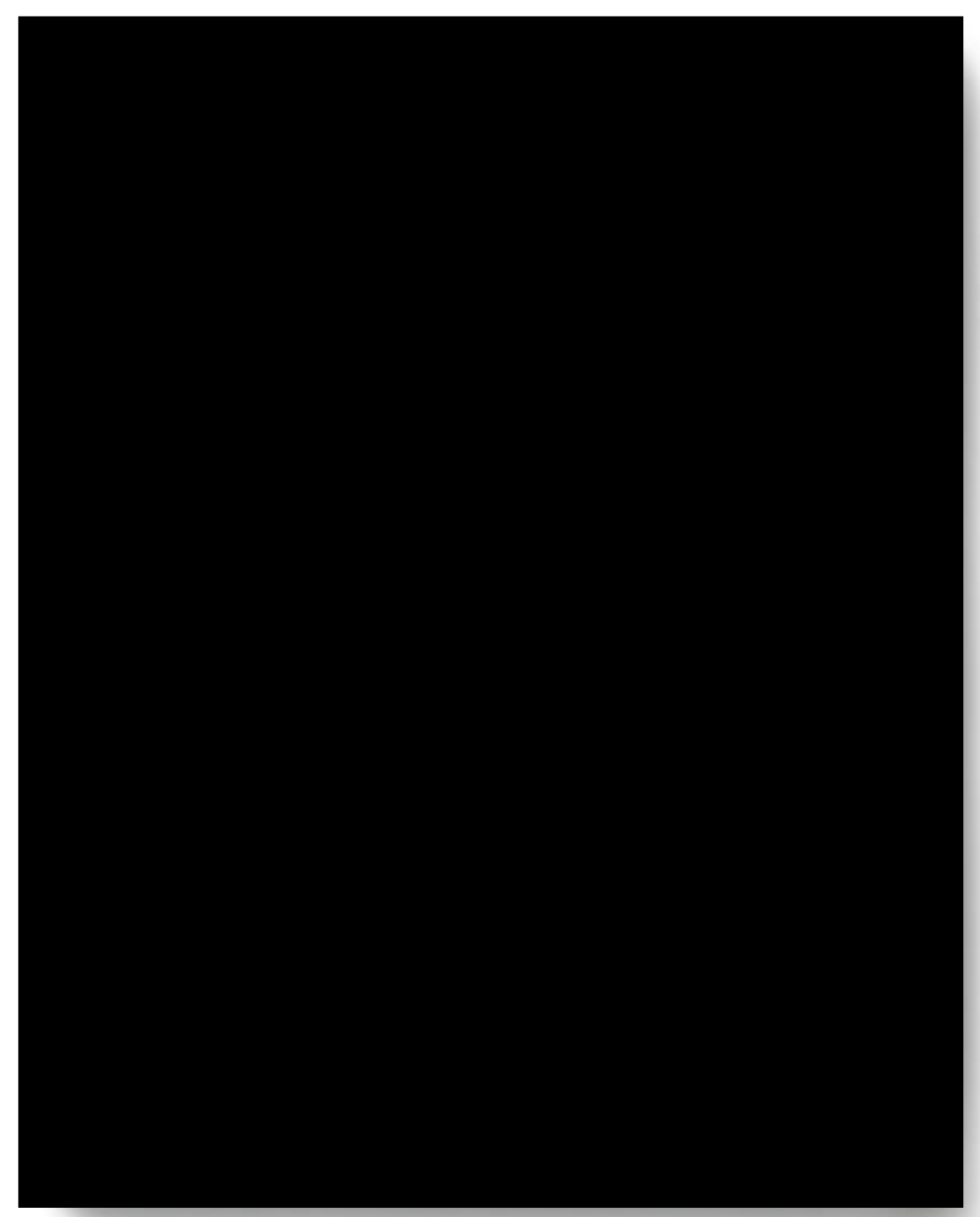

Fig. 36: Erik Kessels, IN ALMOST EVERY PICTURE \#13, 2014, book. Detail retrieved from http://kesselskramerpublishing.com/catalogue/in-almost-everypicture-13/. Accessed 30 July 2018. 


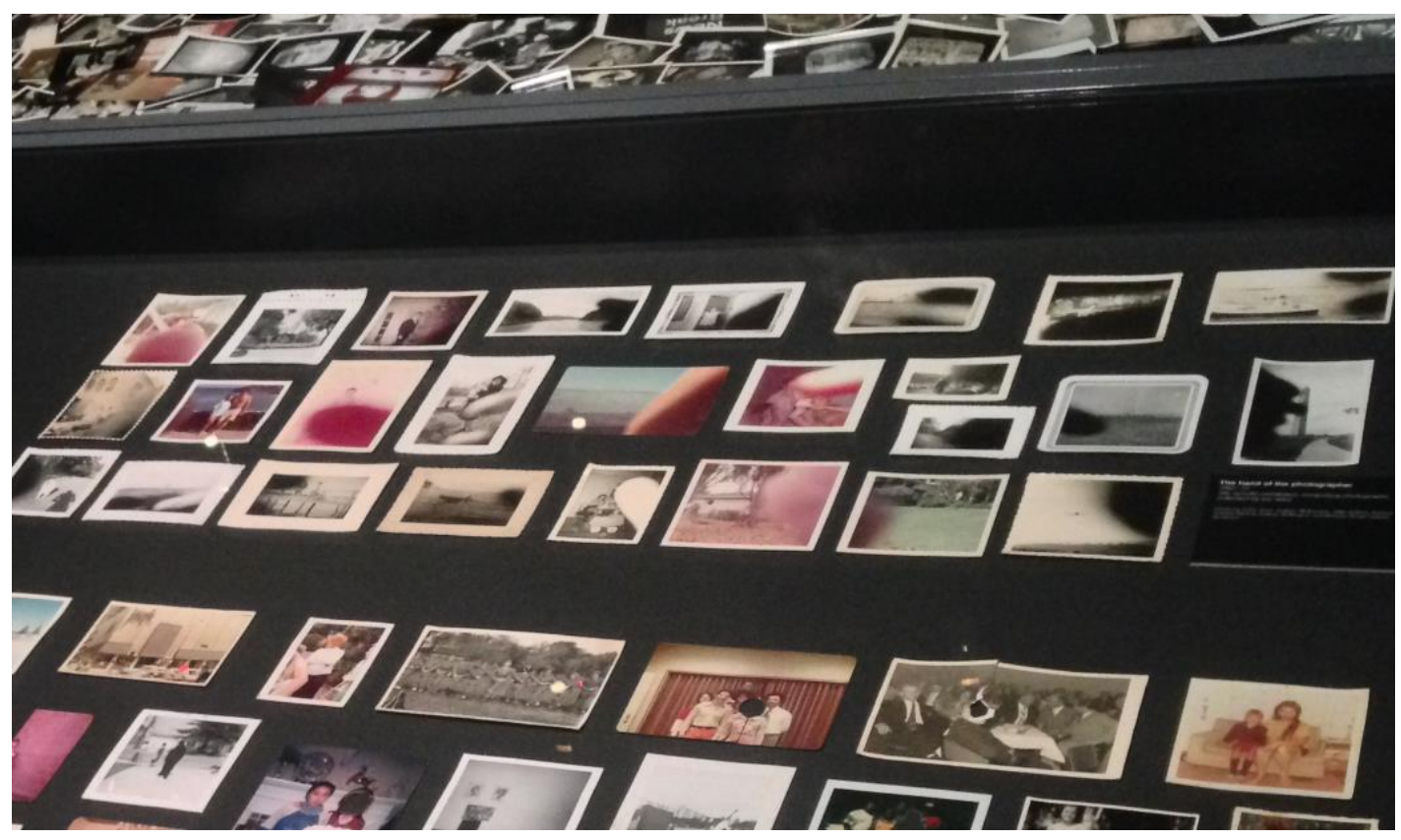

Fig. 37: Detail from The hand of the photographer at Patrick Pound: The Great Exhibition, May 2017, photograph by author. 


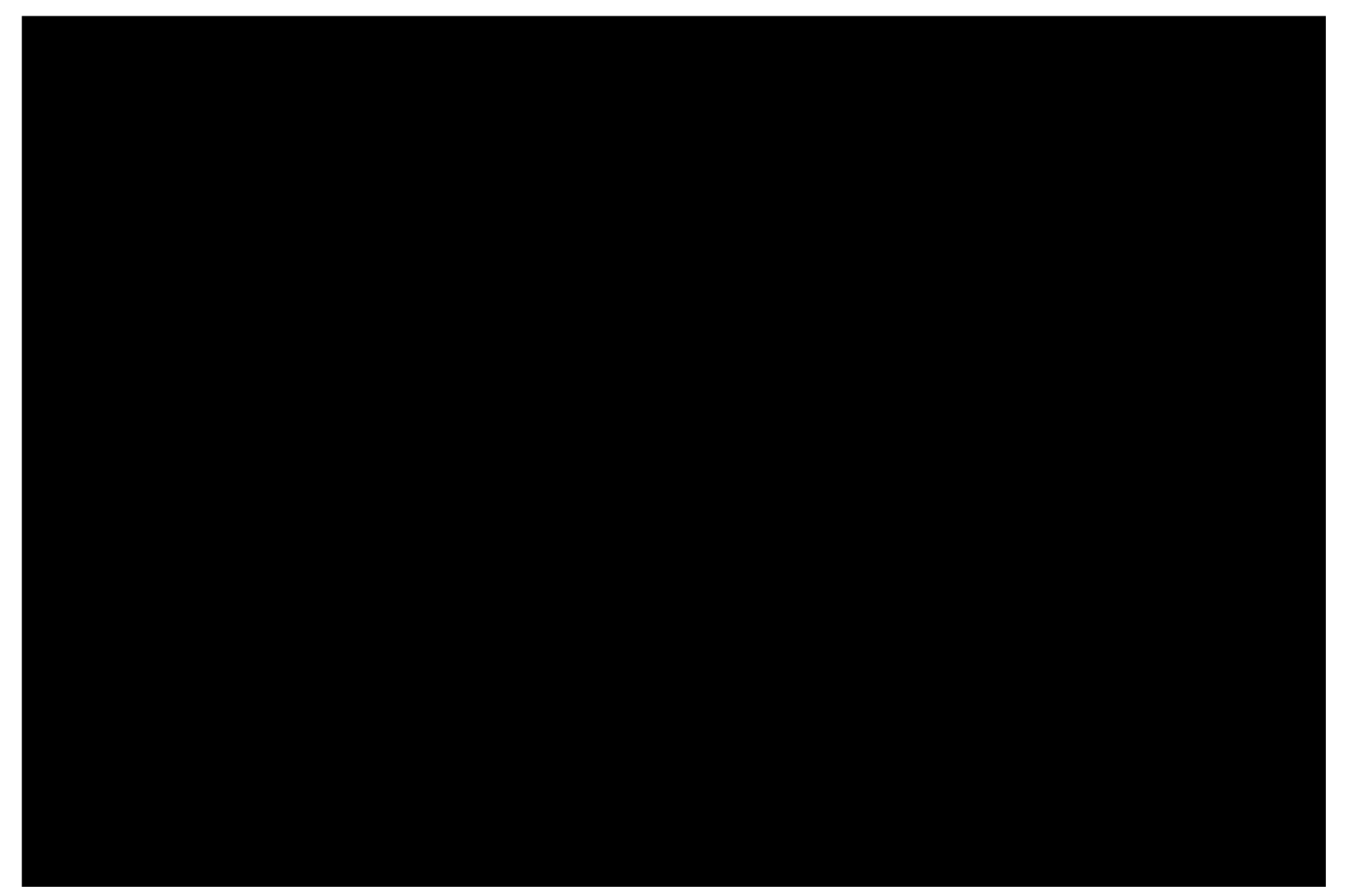

Fig. 38: Patrick Pound, Documentary Intersect, multimedia, installation staged 30 July 2016 - 18 September 2016 at Adam Art Gallery: Wellington, New Zealand. Retrieved from http://www.adamartgallery.org.nz/past-exhibitions/opening-friday29-july-6pm/. Accessed 30 July 2018. 


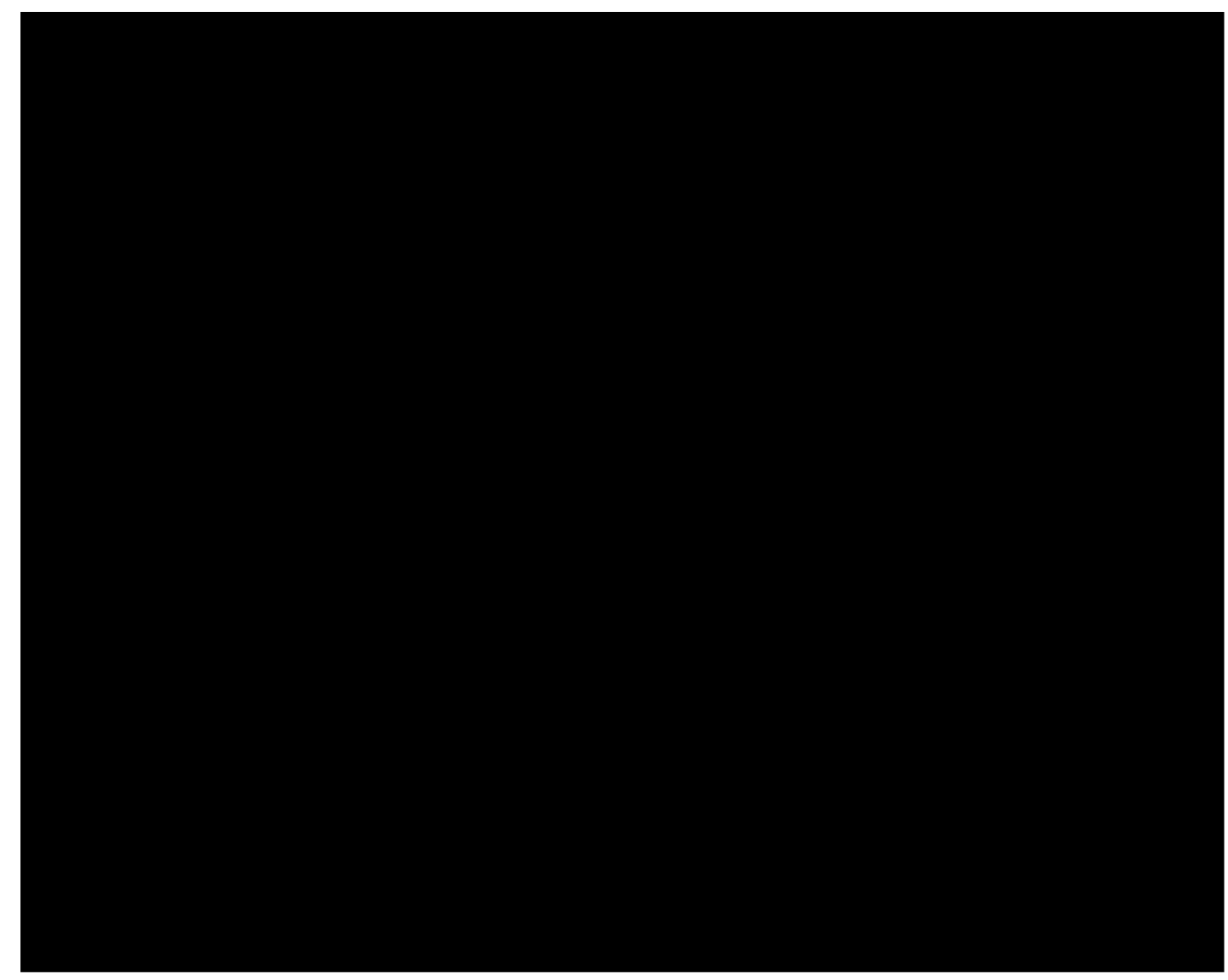

Fig. 39: Joachim Schmid, Archiv \#001, 1986, postcards mounted and framed, (collection unknown). 


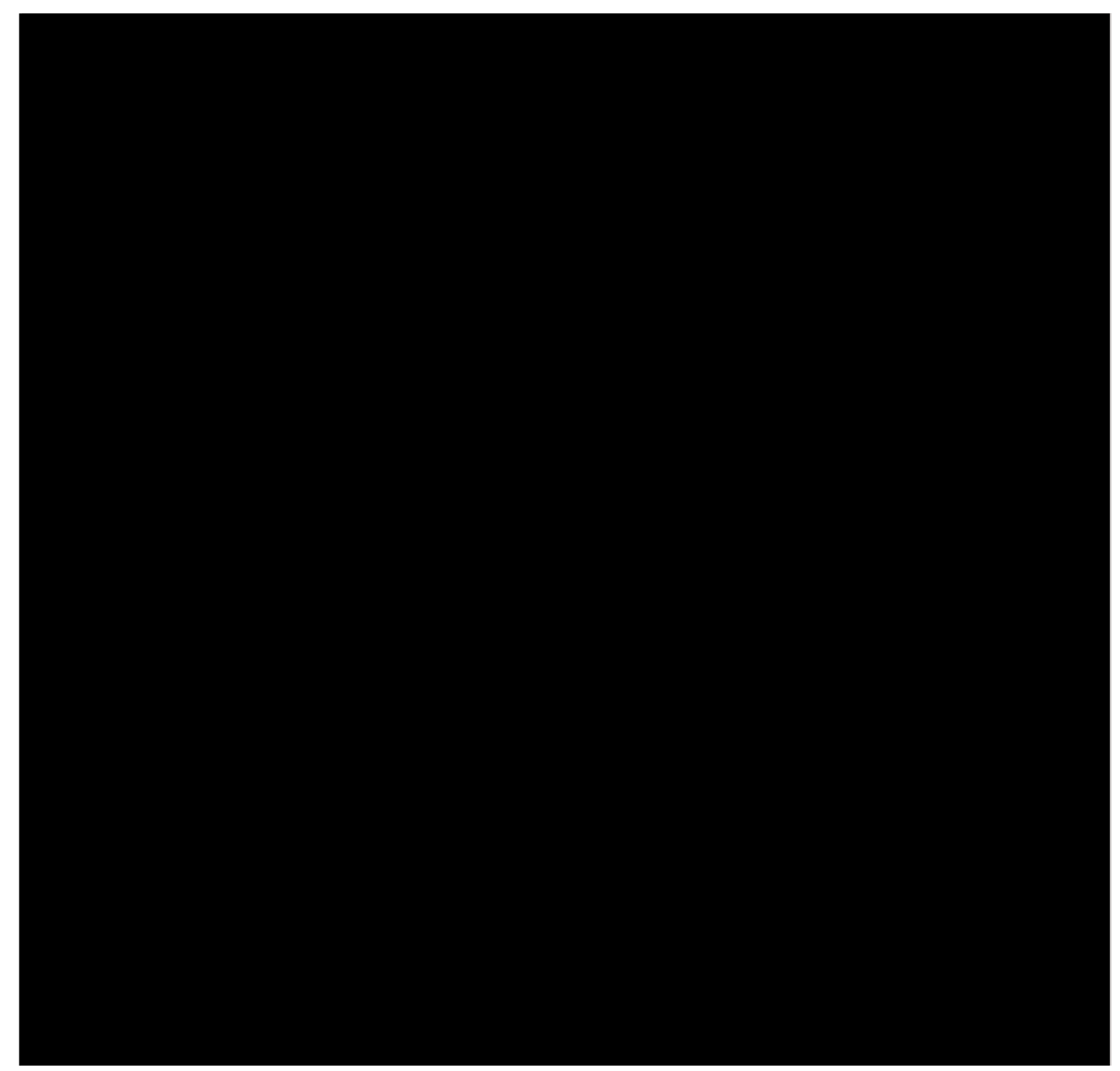

Fig. 40: Marcel Duchamp, The bride stripped bare by her bachelors, even (The green box), 1934, multimedia, (Metropolitan Museum of Art, New York, NY). 


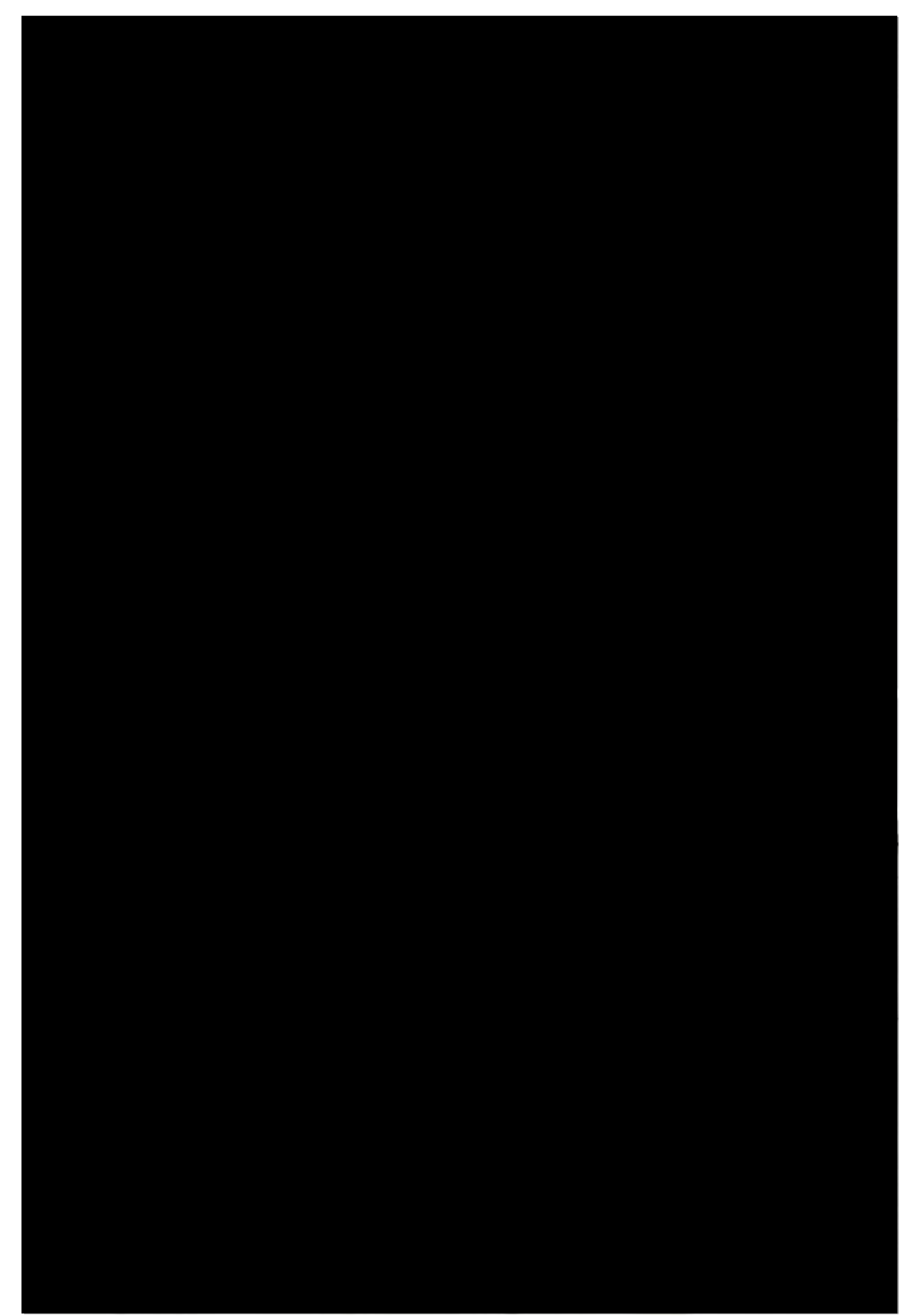

Fig. 41: Marcel Duchamp, The bride stripped bare by her bachelors, even (The Large Glass), 1915-1923, oil, varnish, lead foil and wire, dust, glass plates, (Philadelphia Museum of Art: Philadelphia, PA). 


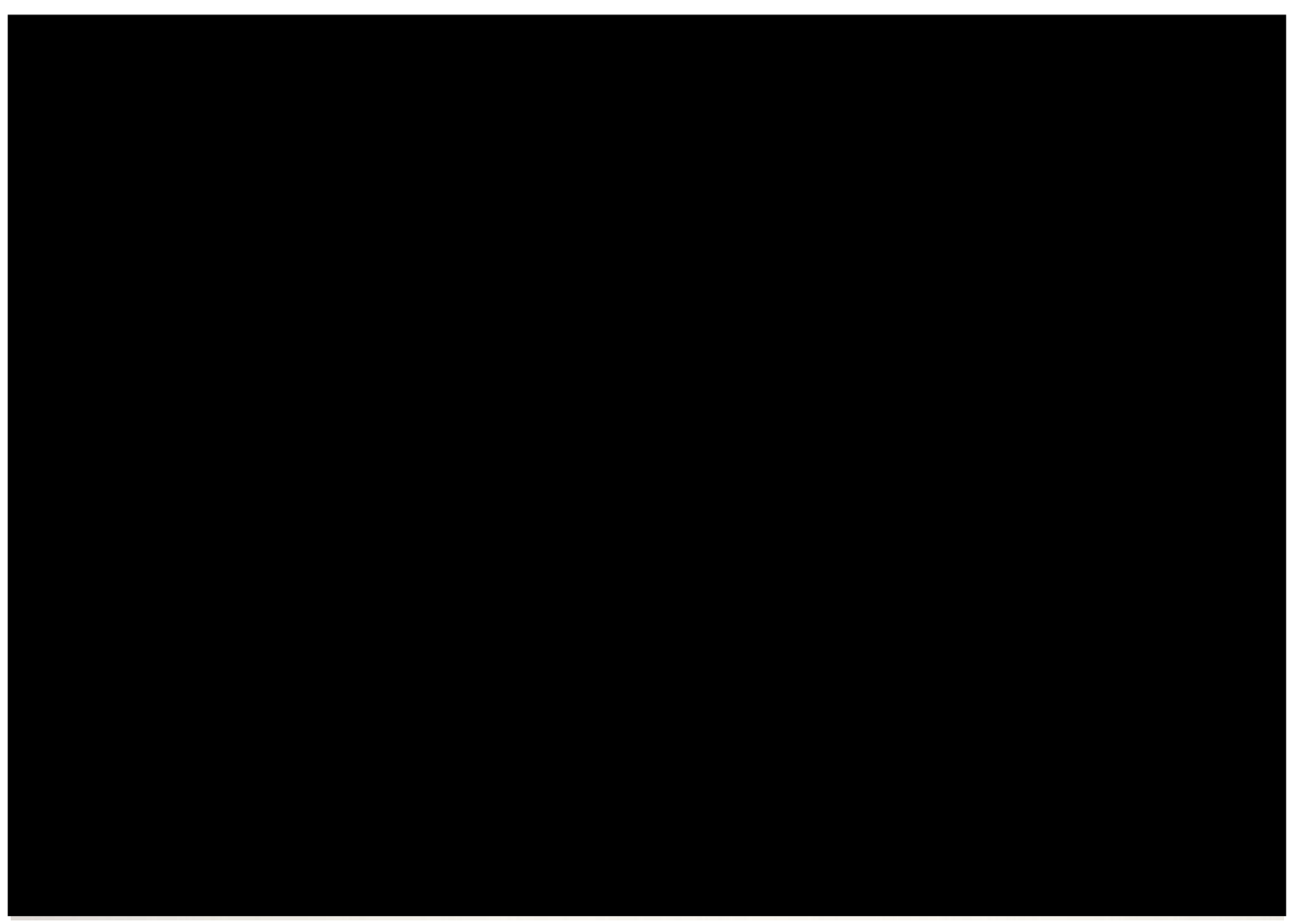

Fig. 42: Marcel Duchamp, Boîte-en-valise, 1935-1941, leather valise, photographs, colour reproductions, collotype on celluloid, (Museum of Modern Art, New York, NY). 


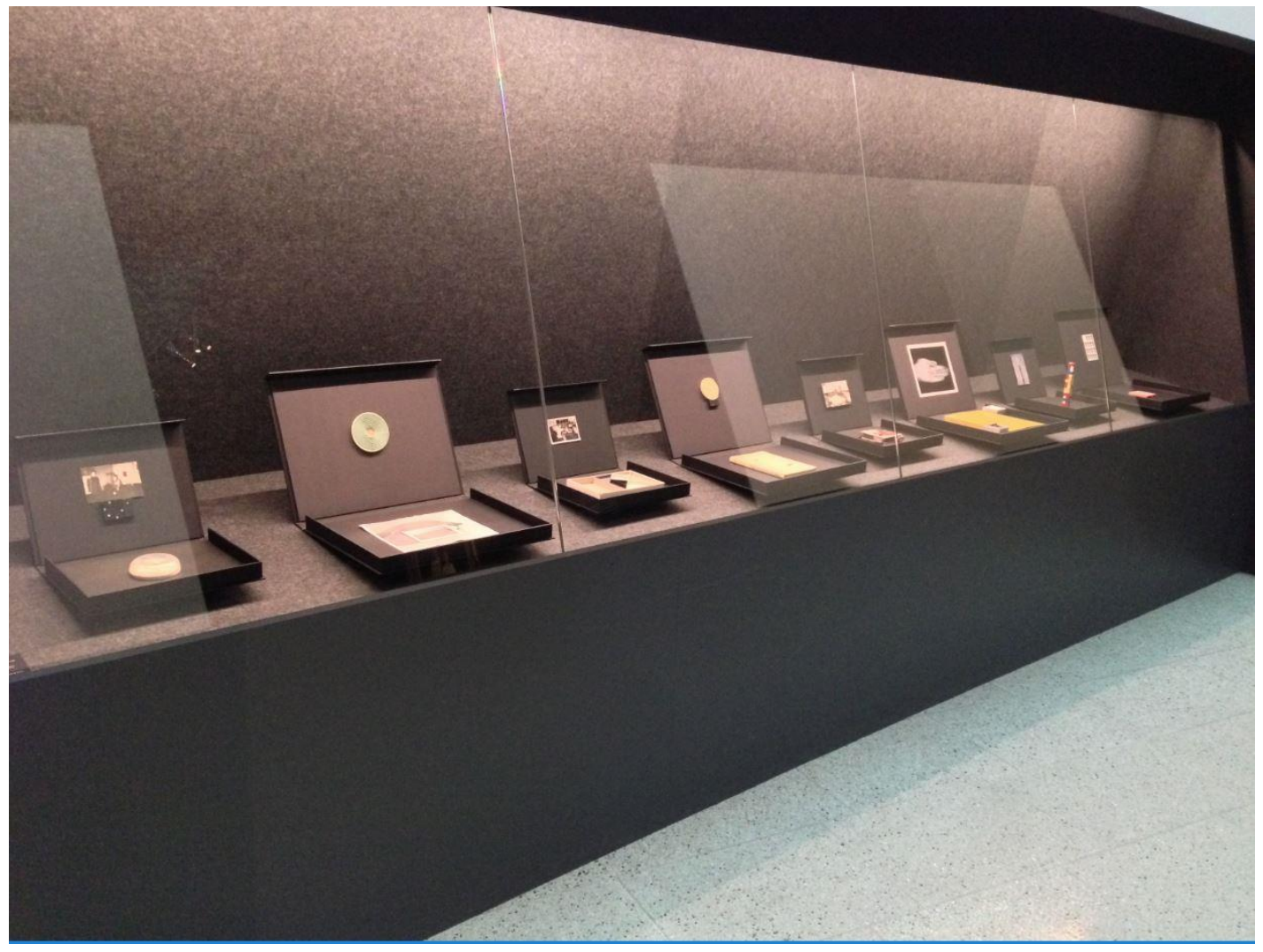

Fig. 43: Detail from The game of things at Patrick Pound: The Great Exhibition, May 2017, photograph by author. 


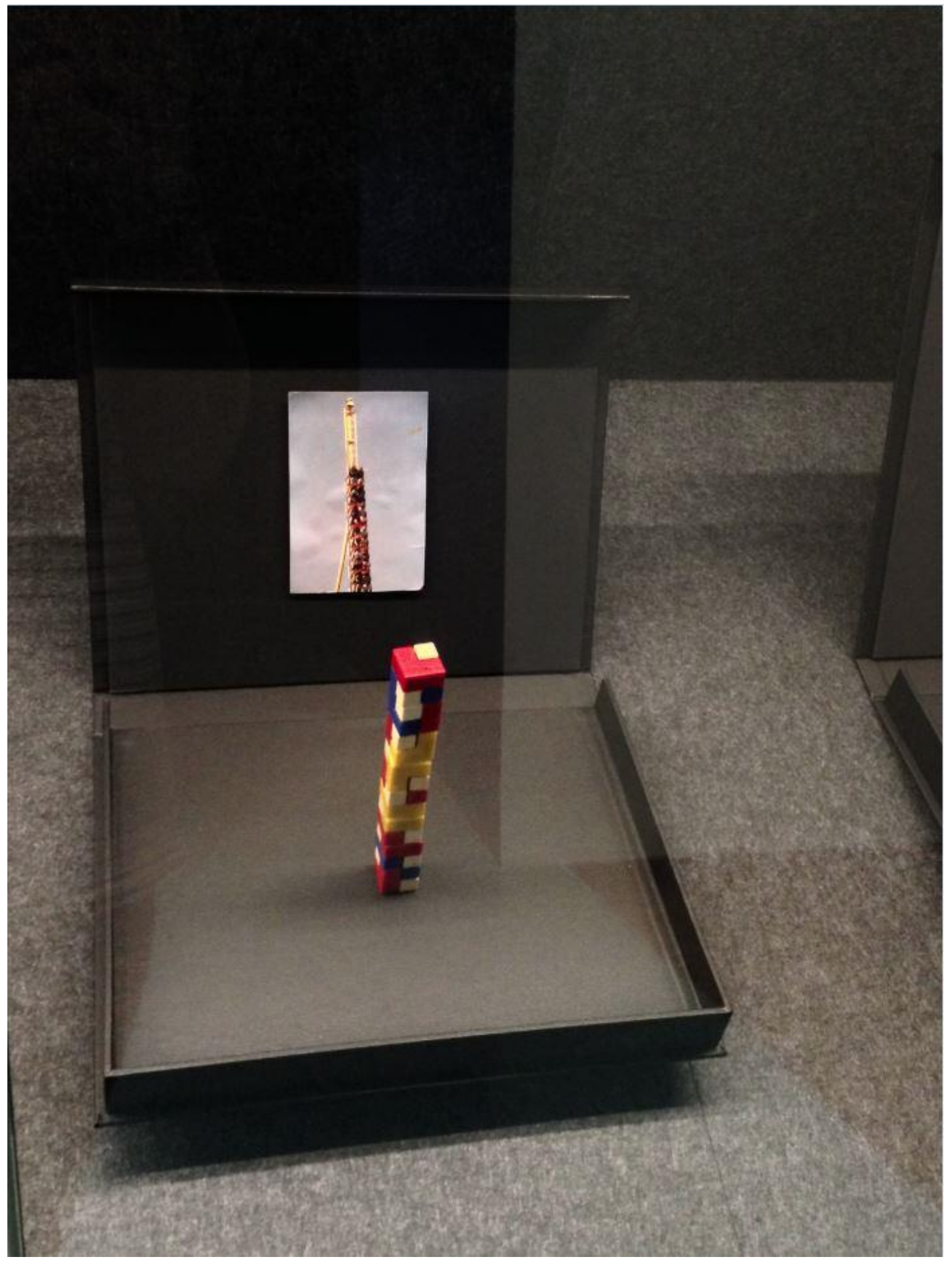

Fig. 44: Detail from The game of things at Patrick Pound: The Great Exhibition, May 2017, photograph by author. 


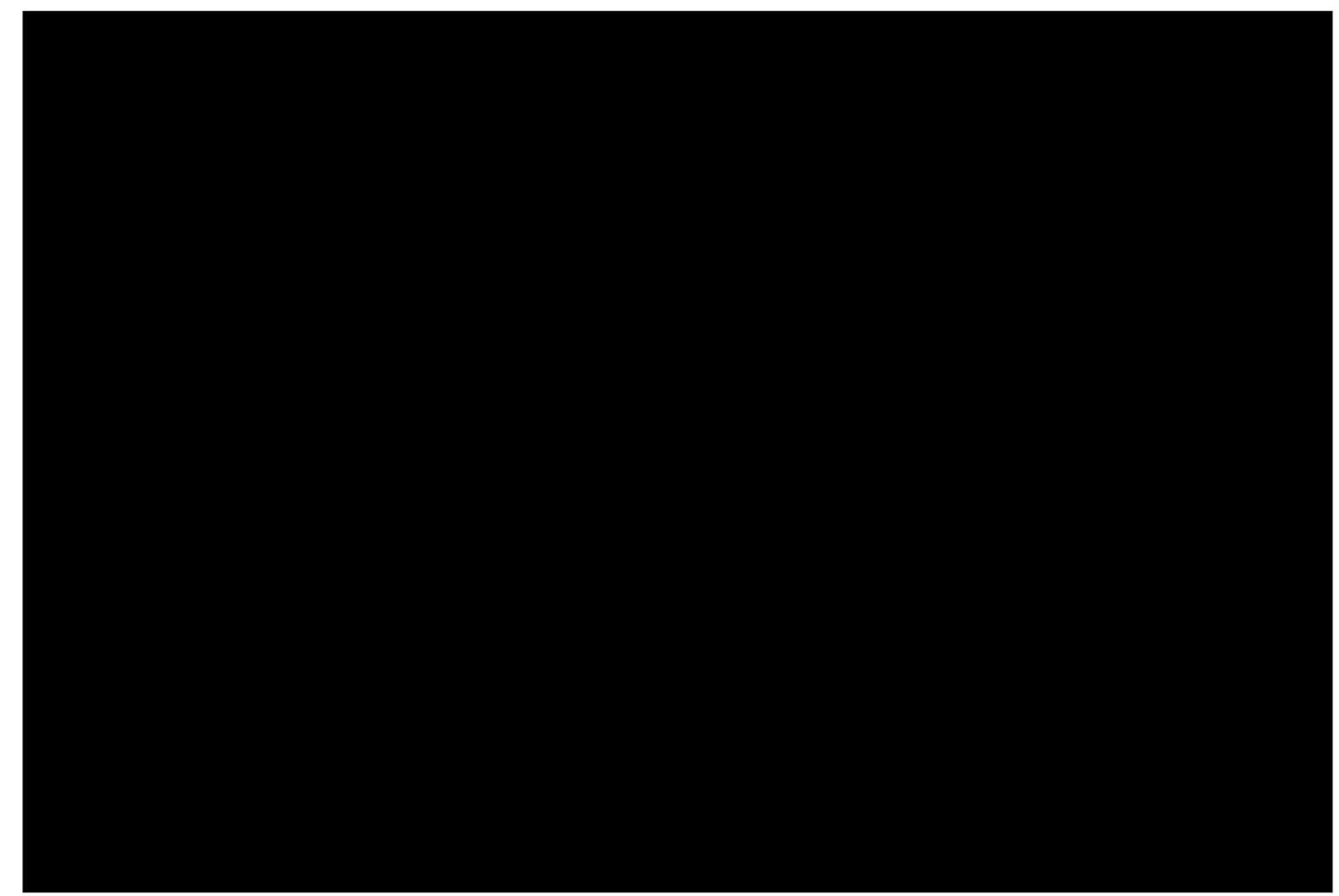

Fig. 45: Detail from Fred Wilson's Mining the Museum, installation staged 3 April 1992 - 28 February 1993 at Maryland Historical Society. Retrieved from http://www.mdhs.org/digitalimage/installation-view-pedestals-globe-and-busts. Accessed 31 July 2018. 


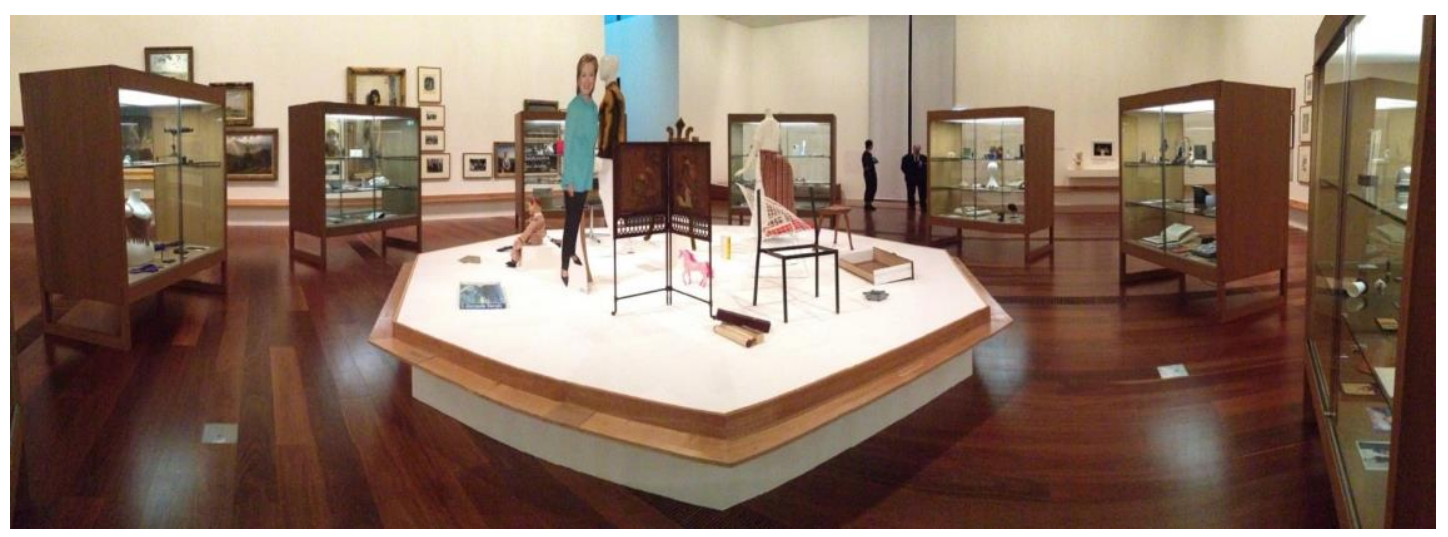

Fig. 46: Installation shot from The Museum of There / Not there at Patrick Pound: The Great Exhibition, May 2017, photograph by author.

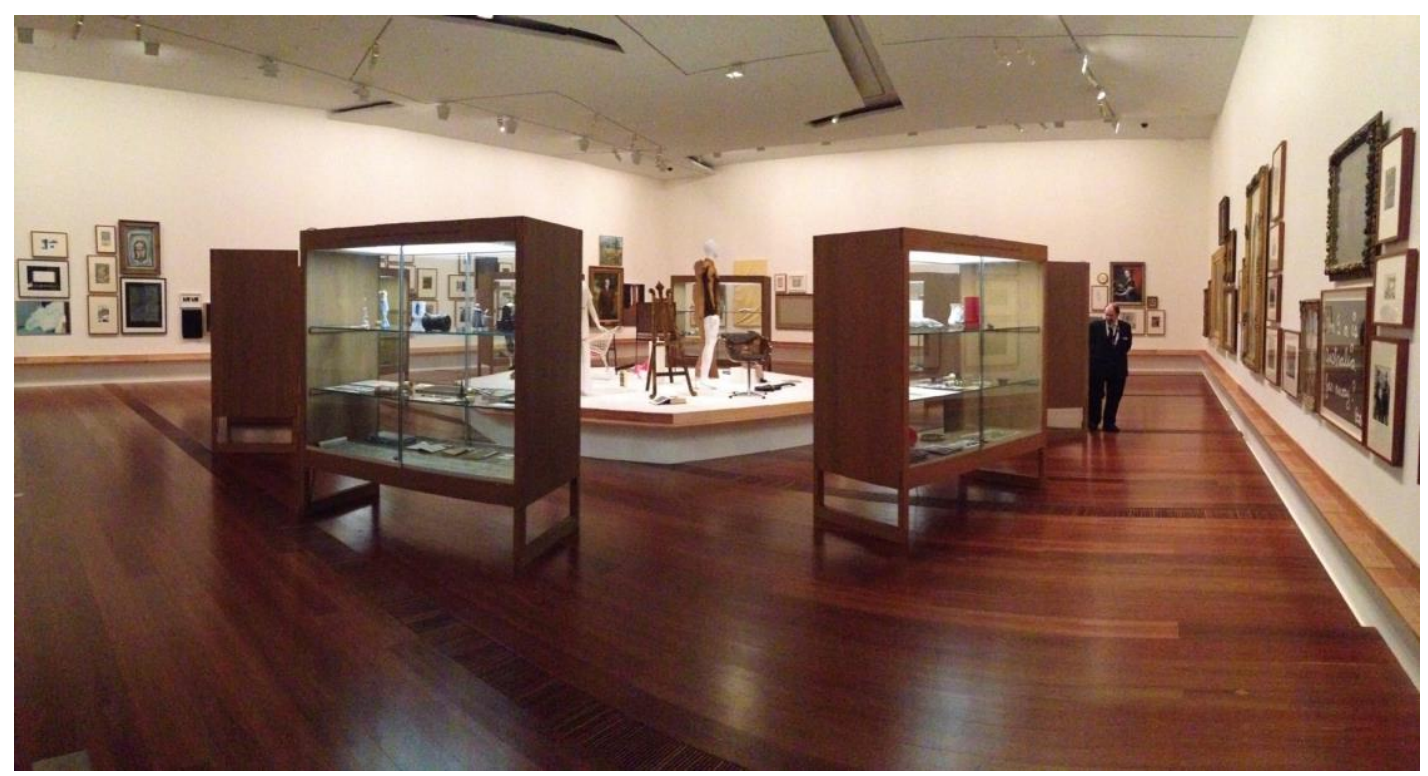

Fig. 47: Installation shot from The Museum of There / Not there at Patrick Pound: The Great Exhibition, May 2017, photograph by author. 


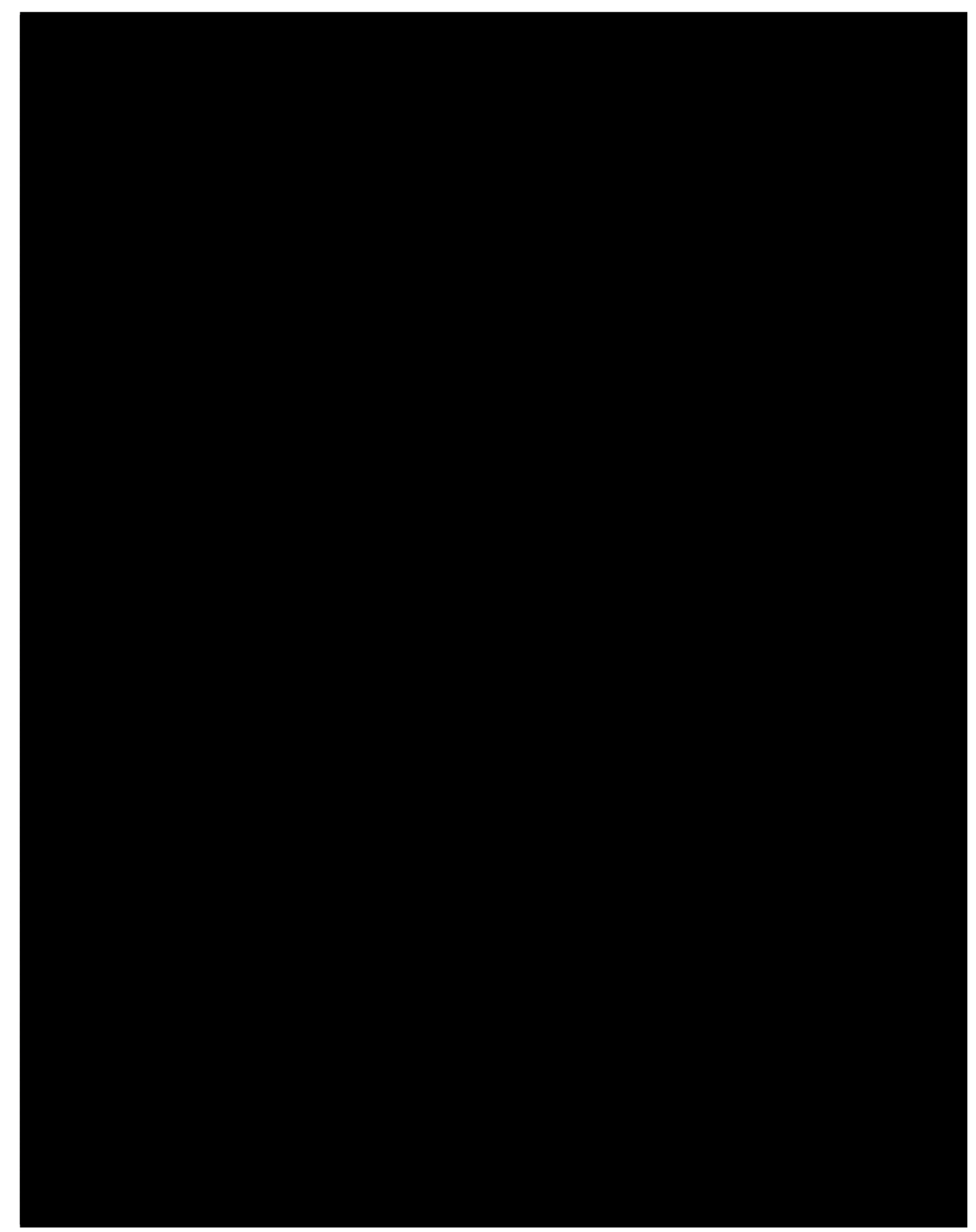

Fig. 48: François Peron, Louis de Freycinet and Arthus Bertrand, Music of the Natives of New South Wales (Musiques des sauvages de la Nouvelle-Galles du Sud), 1824, engraving, (NGV: Melbourne, Australia). 


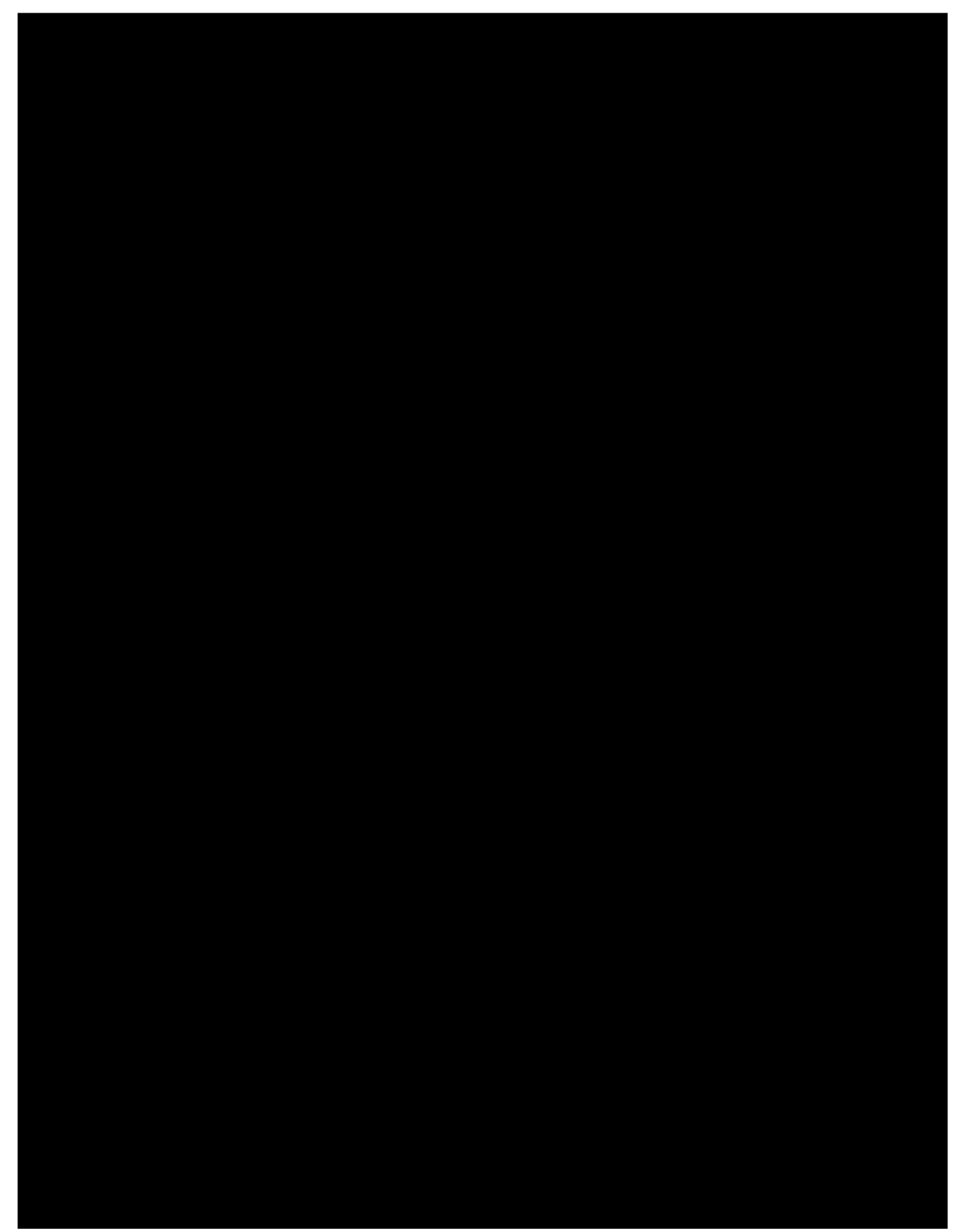

Fig. 49: Unknown, Bennelong, 1802 engraving and etching, (NGV: Melbourne, Australia). 


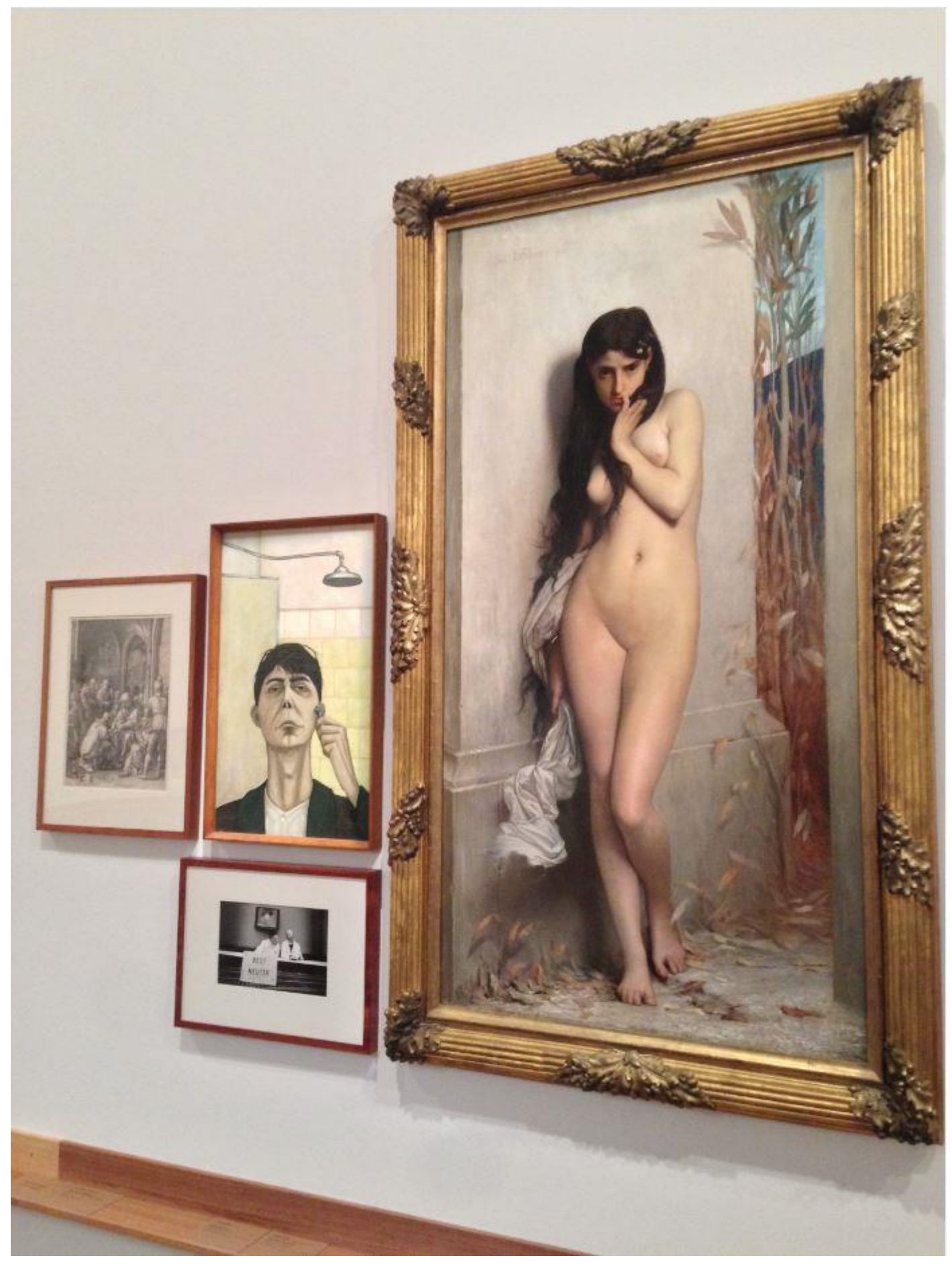

Fig. 50: Installation shot from The Museum of There / Not there at Patrick Pound: The Great Exhibition, May 2017, photograph by author. 


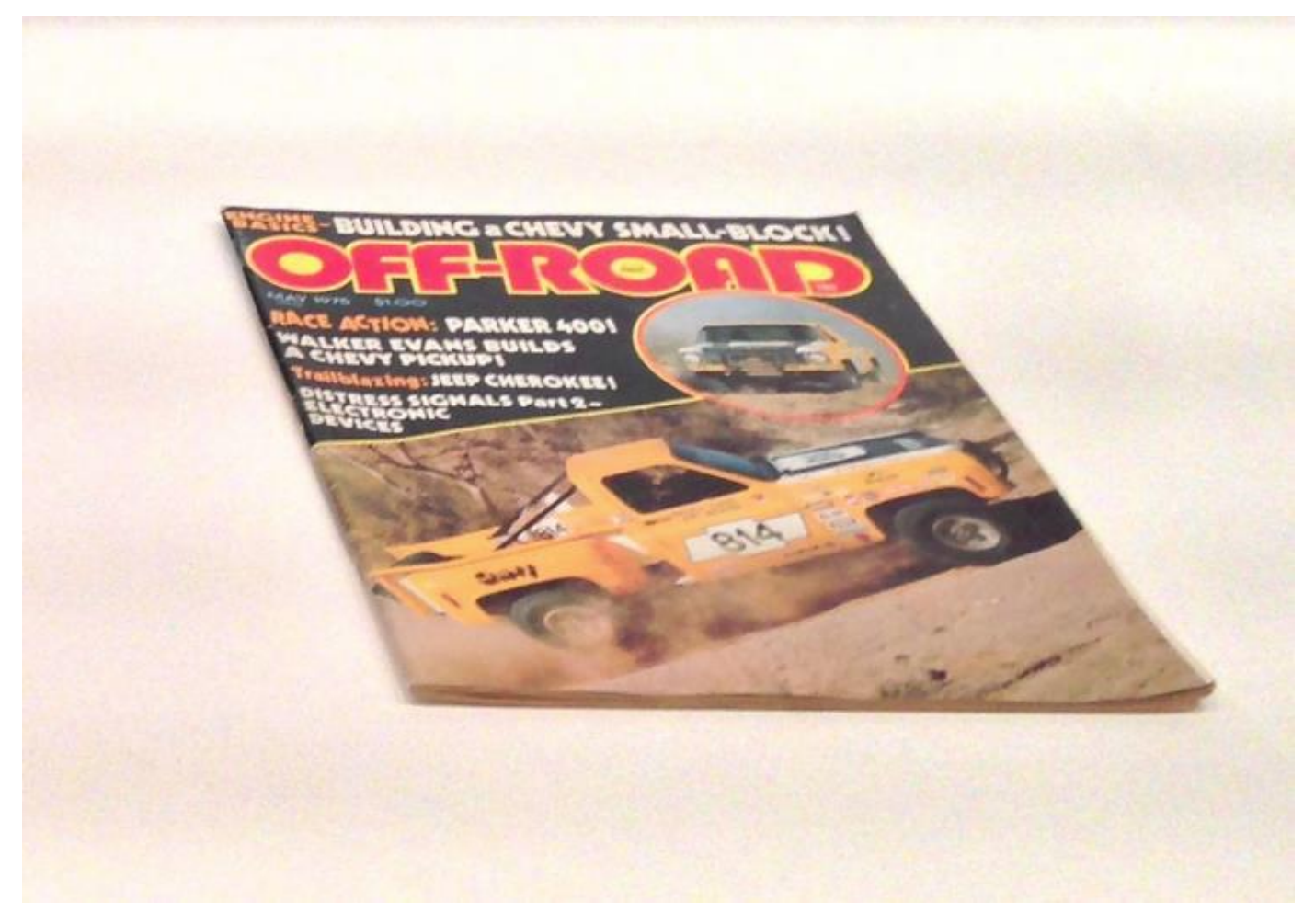

Fig. 51: Detail from The names in The collection shelves in Patrick Pound: The Great Exhibition, May 2017, photograph by author. 


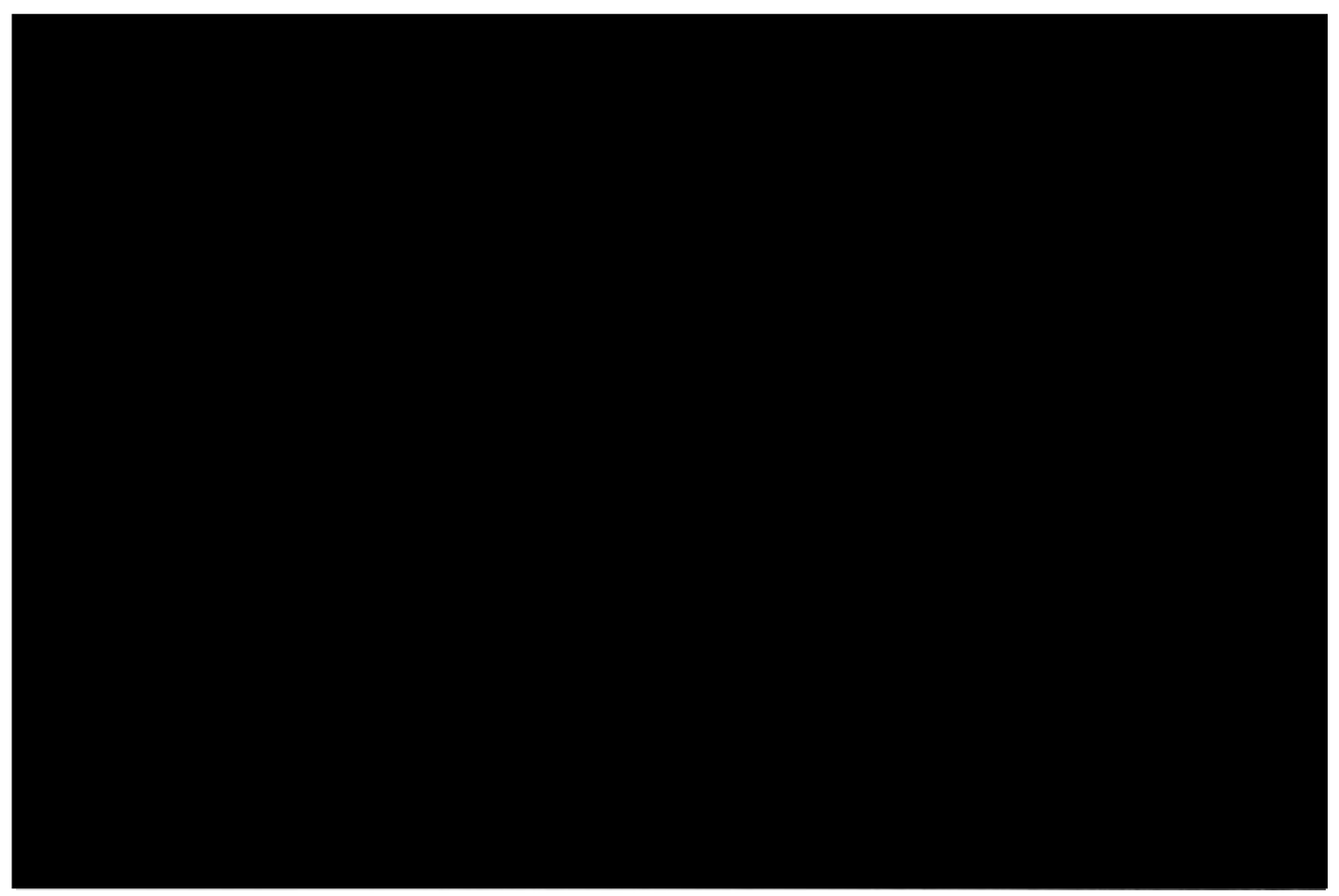

Fig. 52: Installation shot from Edward Steichen's The Family of Man, exhibition staged 24 January 1955 - 8 May 1955 at Museum of Modern Art. Retrieved from https://www.moma.org/calendar/exhibitions/2429. Accessed 31 July 2018. 


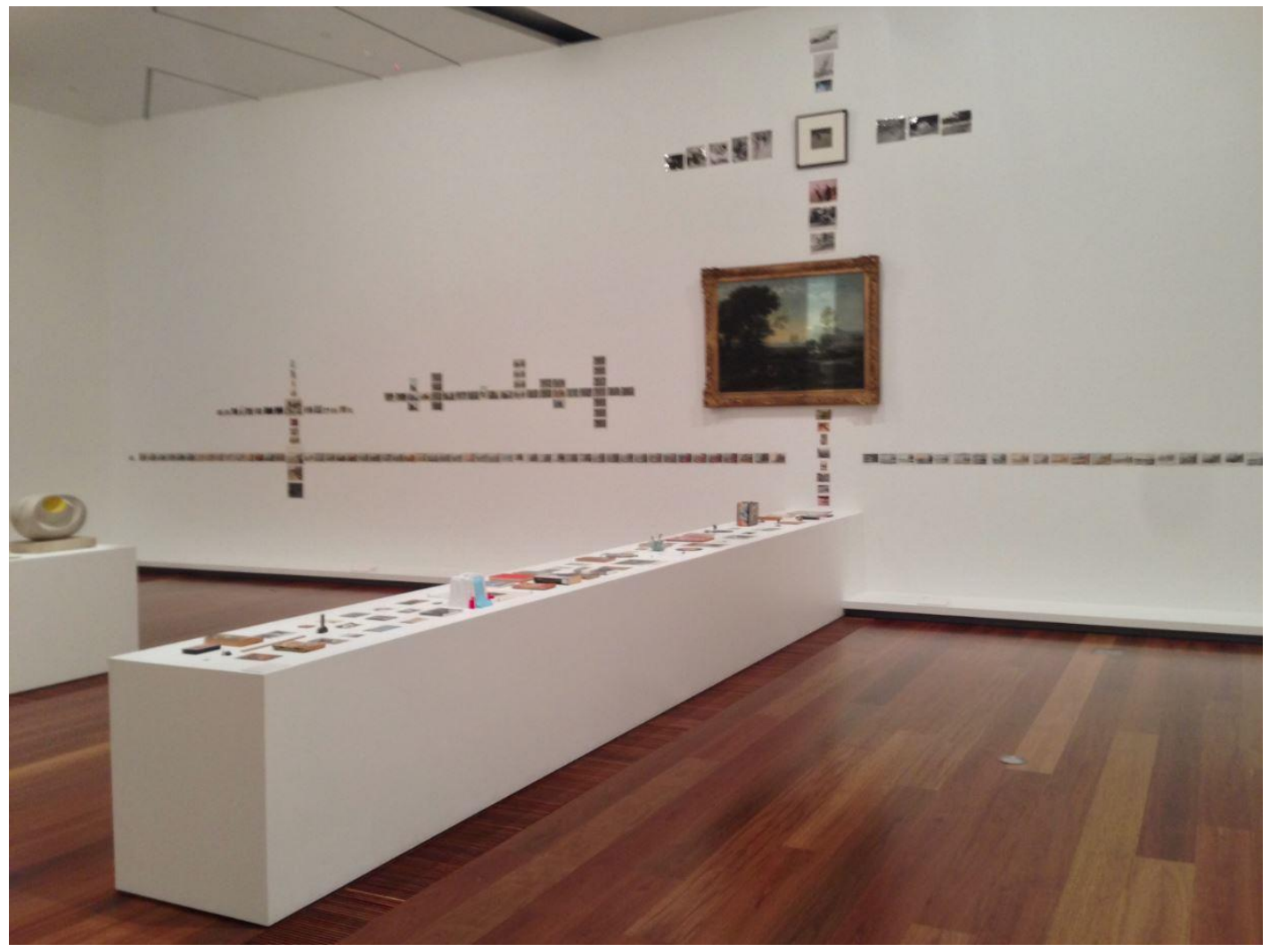

Fig. 53: Installation shot from The Museum of Falling in Patrick Pound: The Great Exhibition, May 2017, photograph by author. 


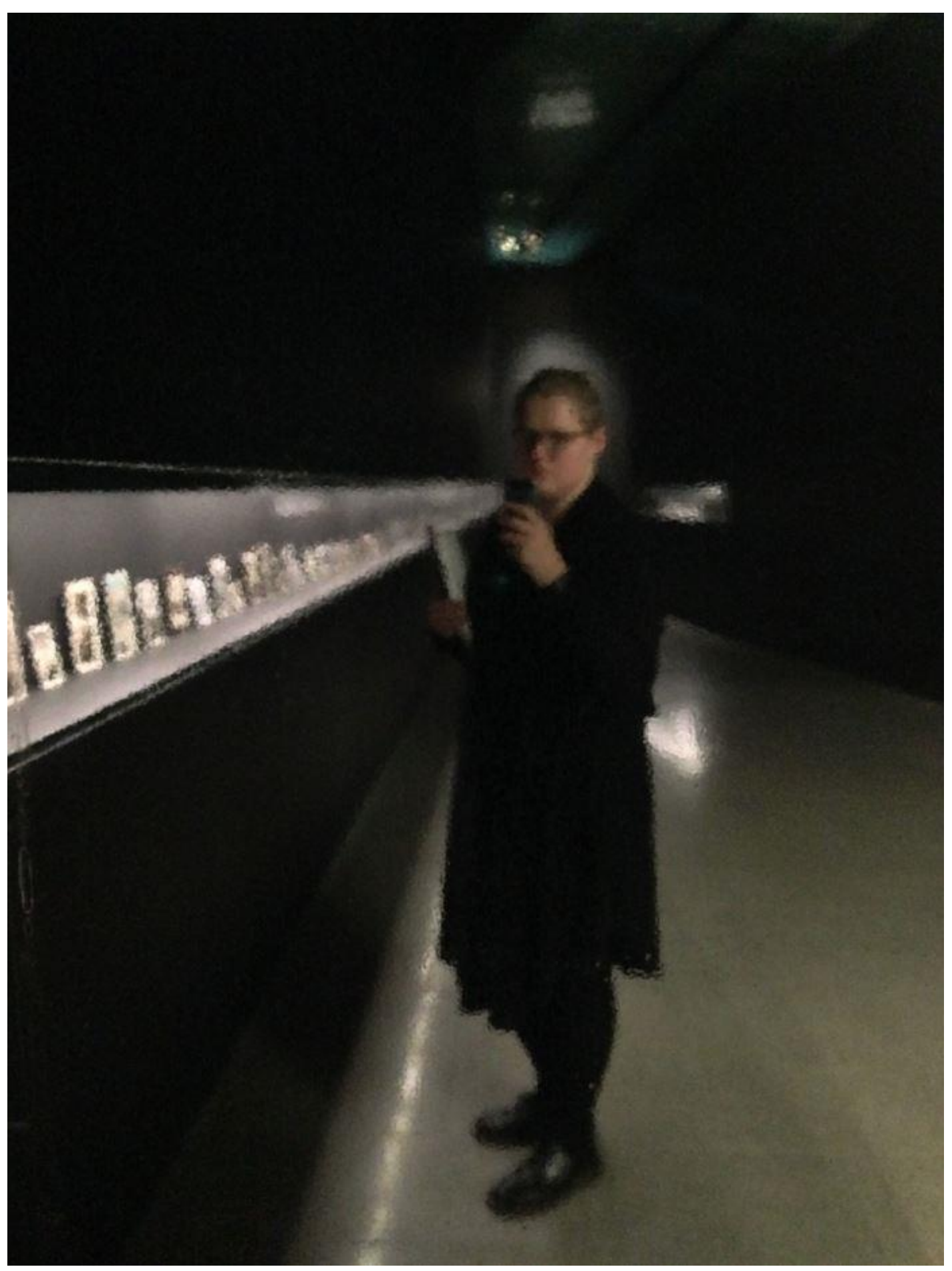

Fig. 54: Photograph of author in reflection beside The photographer's shadow in Patrick Pound: The Great Exhibition, May 2017, photograph by author. 


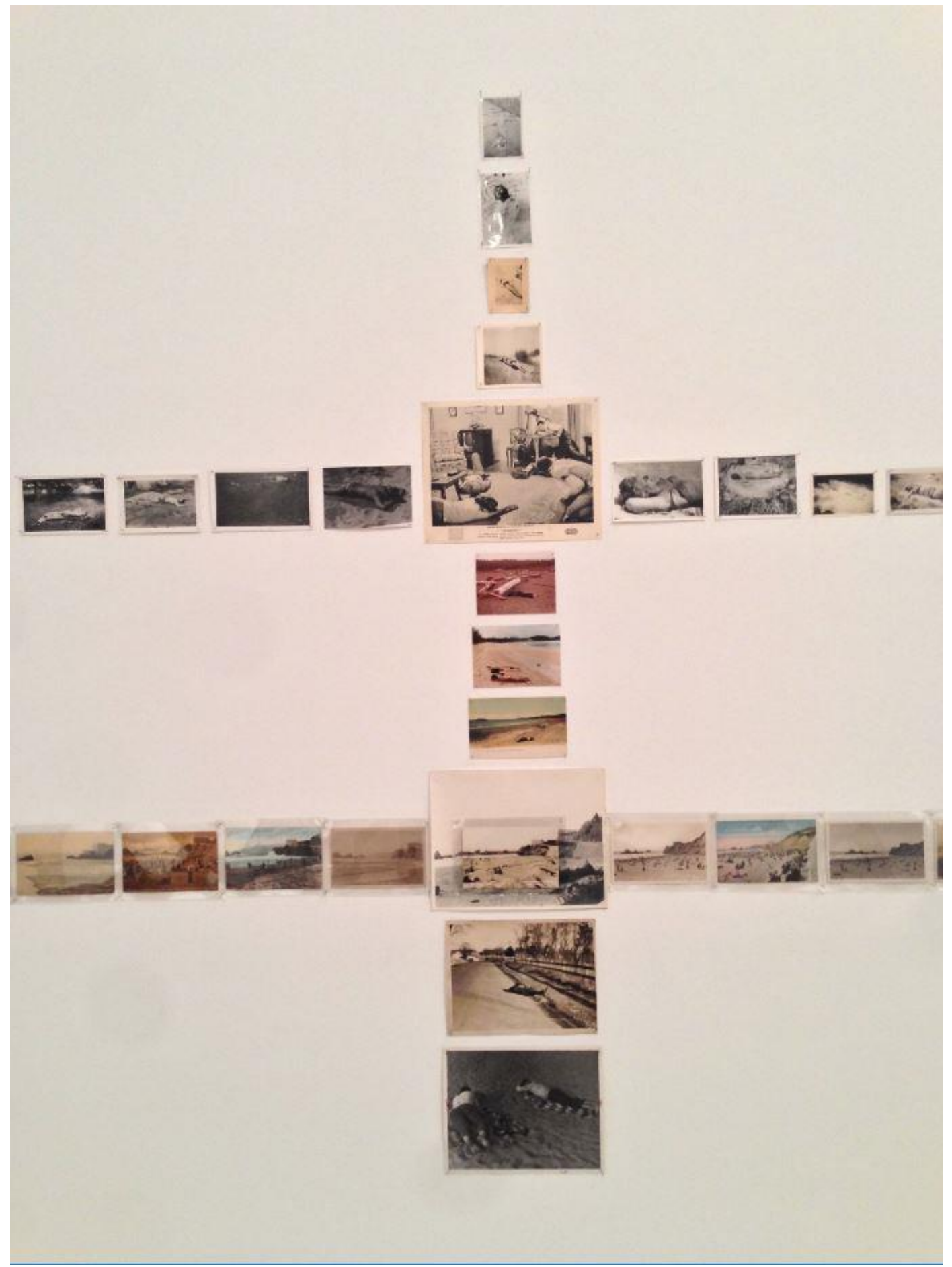

Fig. 55: Detail from The Cliff House and intersections in Patrick Pound: The Great Exhibition, May 2017, photograph by author. 


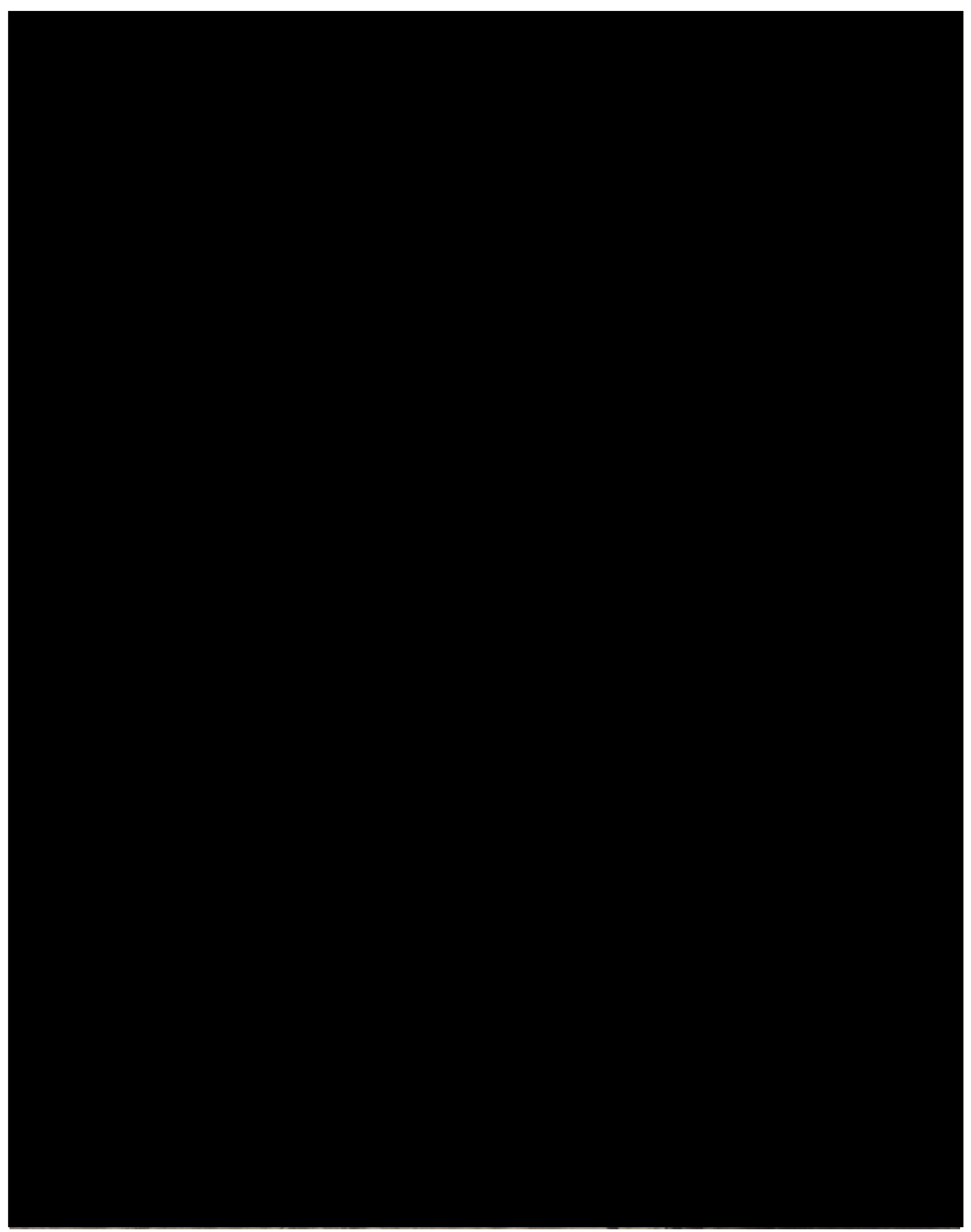

Fig. 56: Detail from The Cliff House in Maggie Finch, The Great Exhibition, ed. Mark Gomes (Melbourne, VIC: National Gallery of Victoria, 2017), 149. 


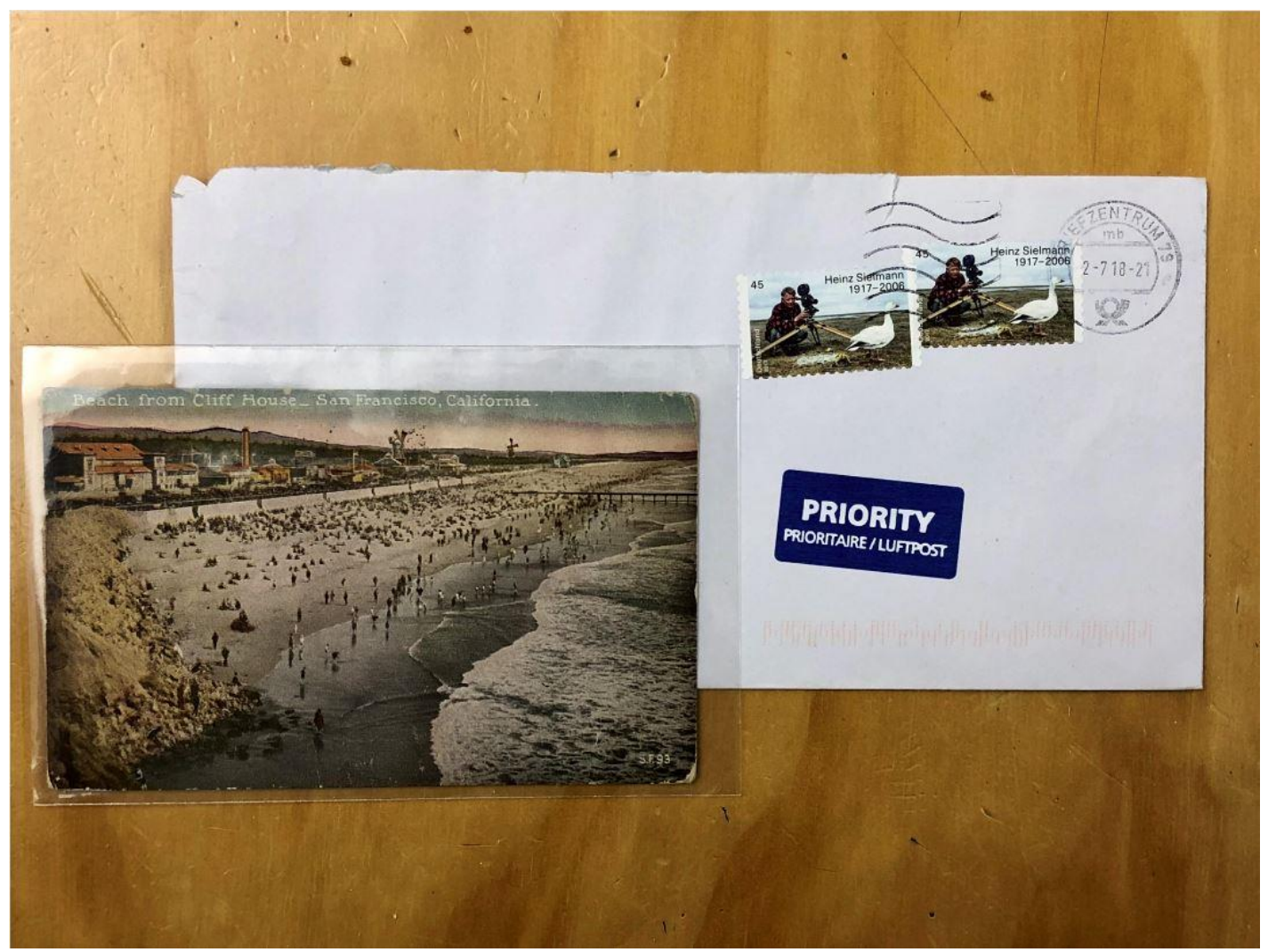

Fig. 57: First postcard of From Cliff House that arrived in an envelope with Heinz Sielmann stamps. Photograph by author. 


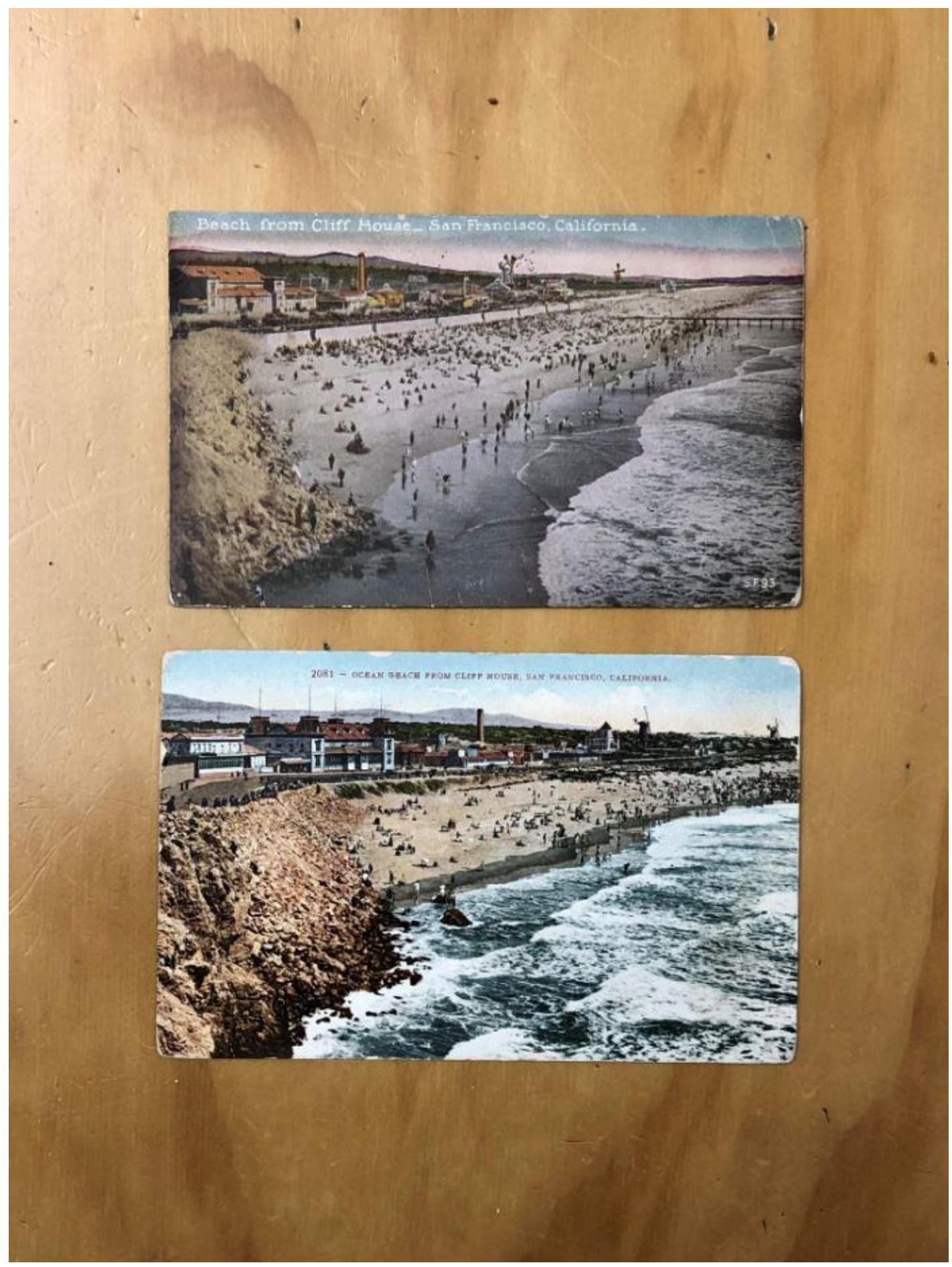

Fig. 58: First [top] and second postcard of From Cliff House. Photograph by author. 


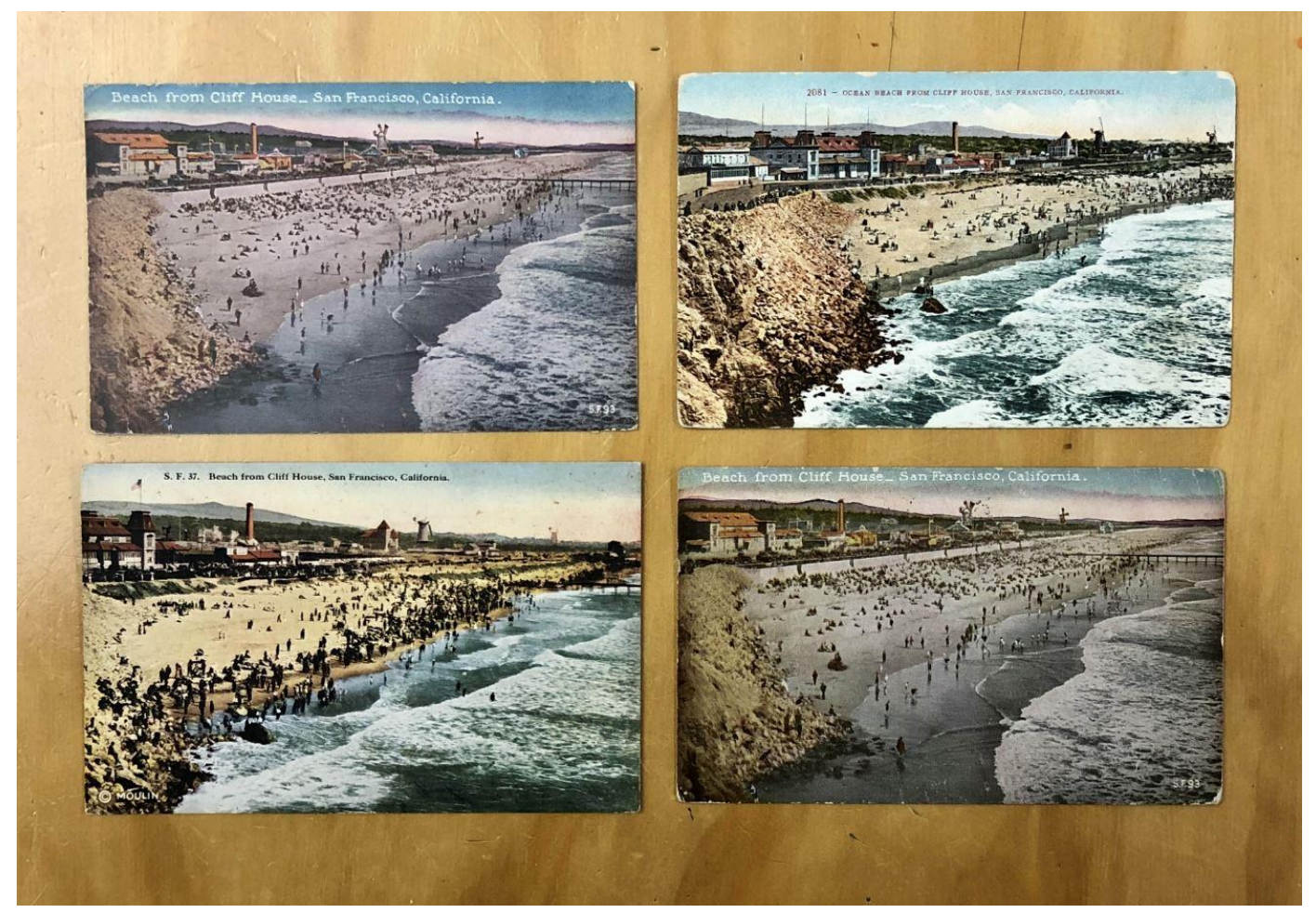

Fig. 59: Four postcards From Cliff House. Photograph by author. 


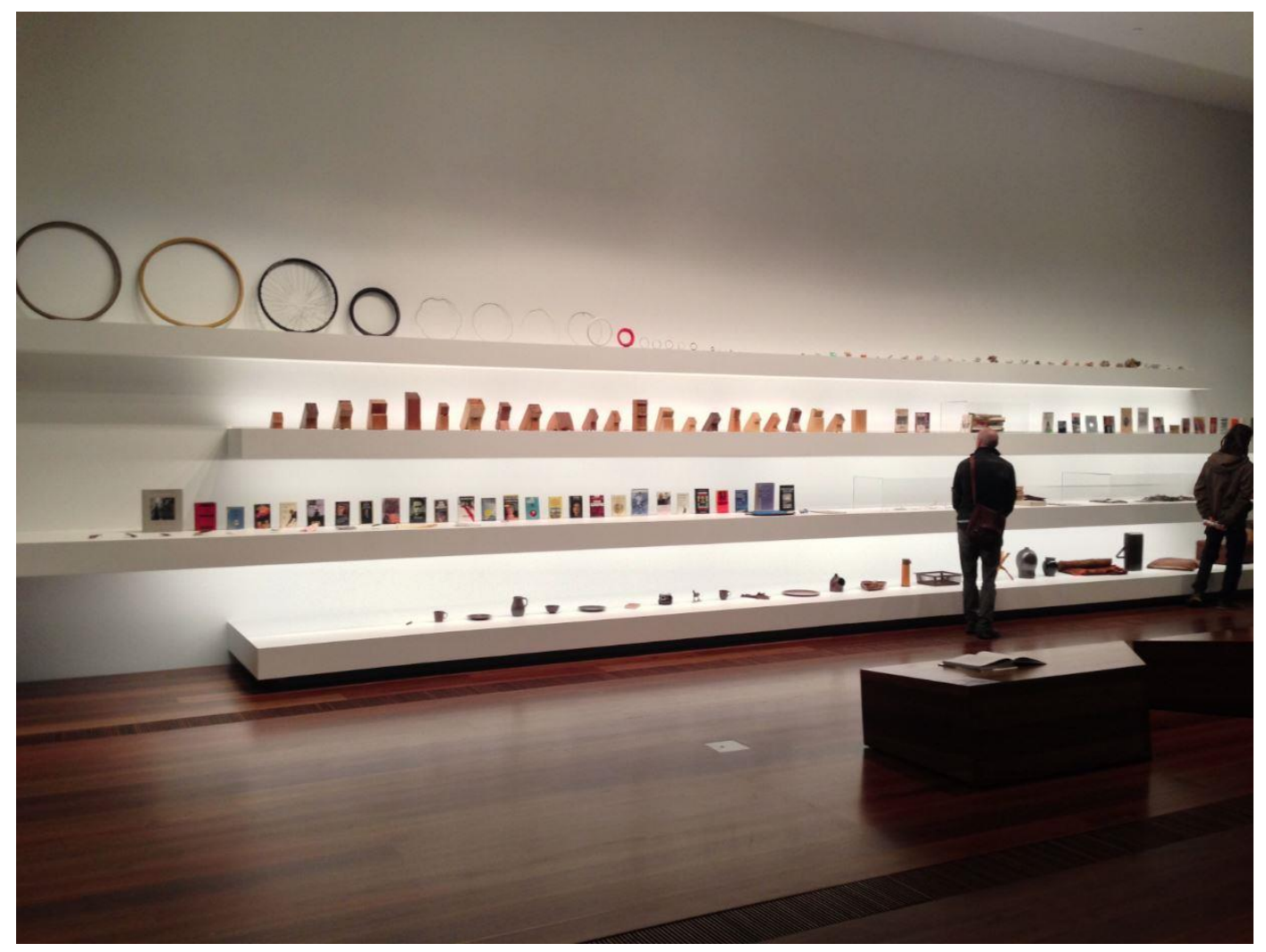

Fig. 60: Installation shot from The collection shelves in Patrick Pound: The Great Exhibition, May 2017, photograph by author. 


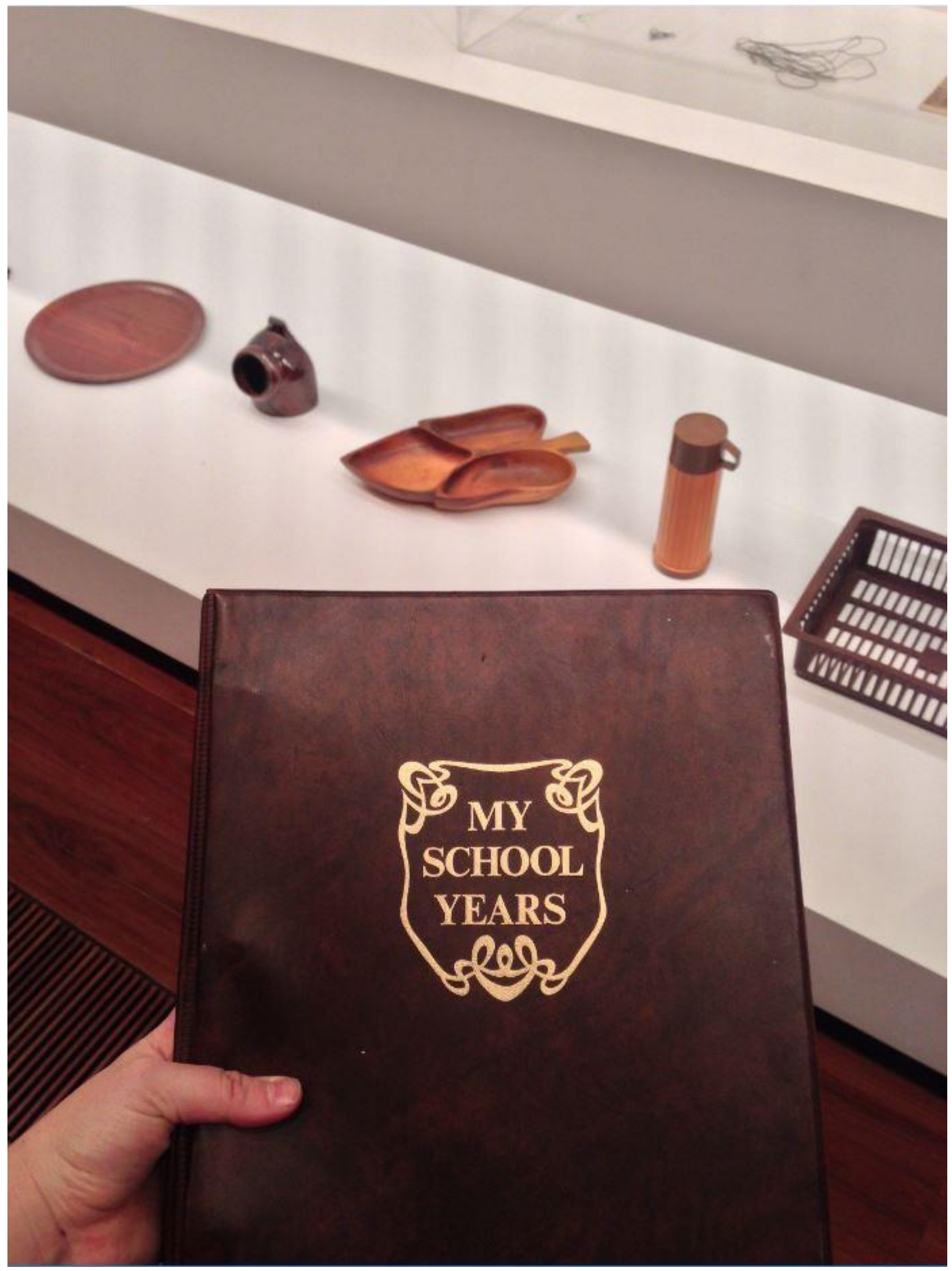

Fig. 61: Detail from 26 brown things from Patrick Pound: The Great Exhibition, May 2017, photograph by author. 


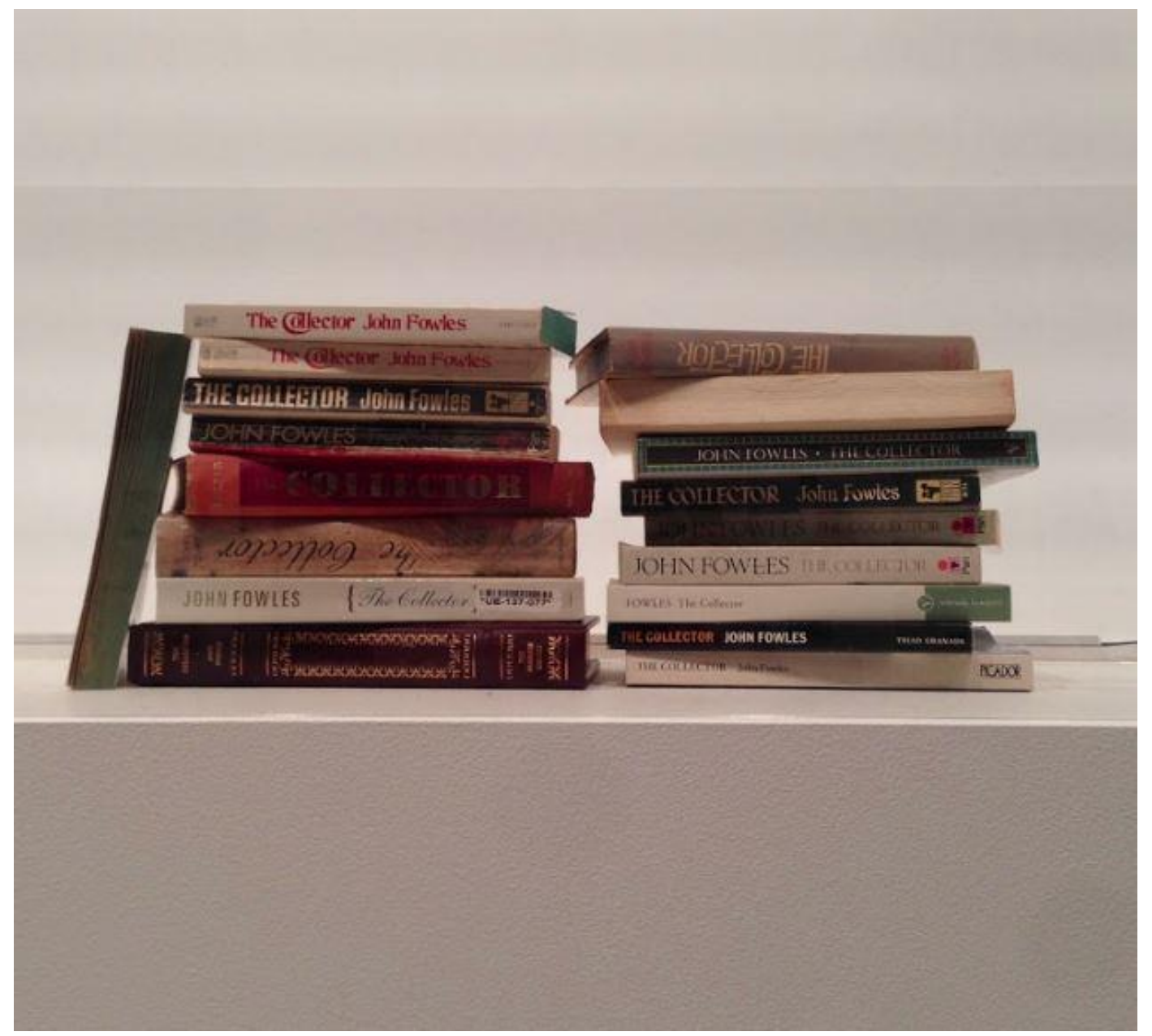

Fig. 62: Detail from The Collector from Patrick Pound: The Great Exhibition, May 2017, photograph by author. 


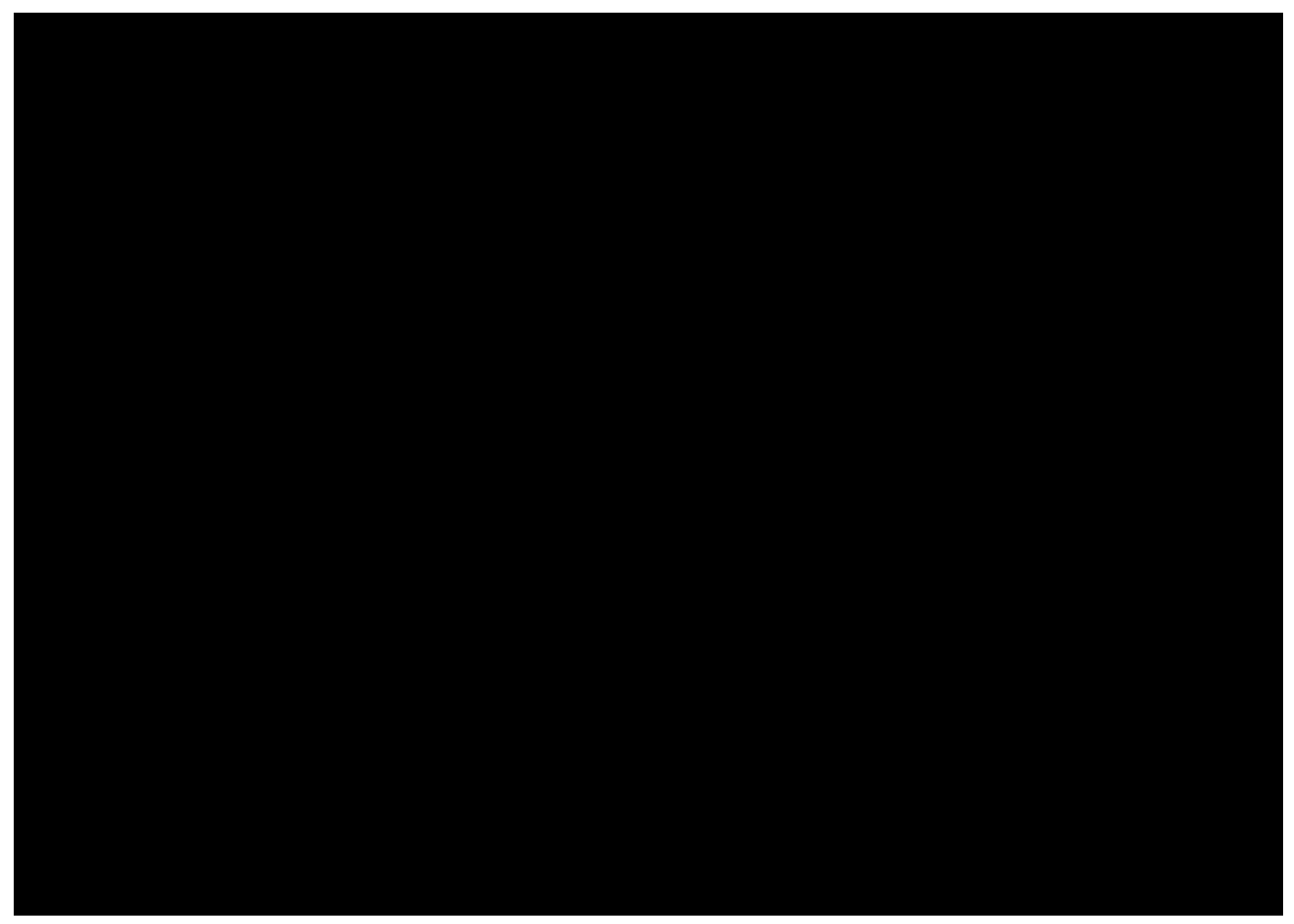

Fig. 63: Félix Vallotton, Point du Jour, banks of the Seine (Point du Jour, bords de la Seine), 1901, oil paint on canvas, (NGV: Melbourne, Australia). 


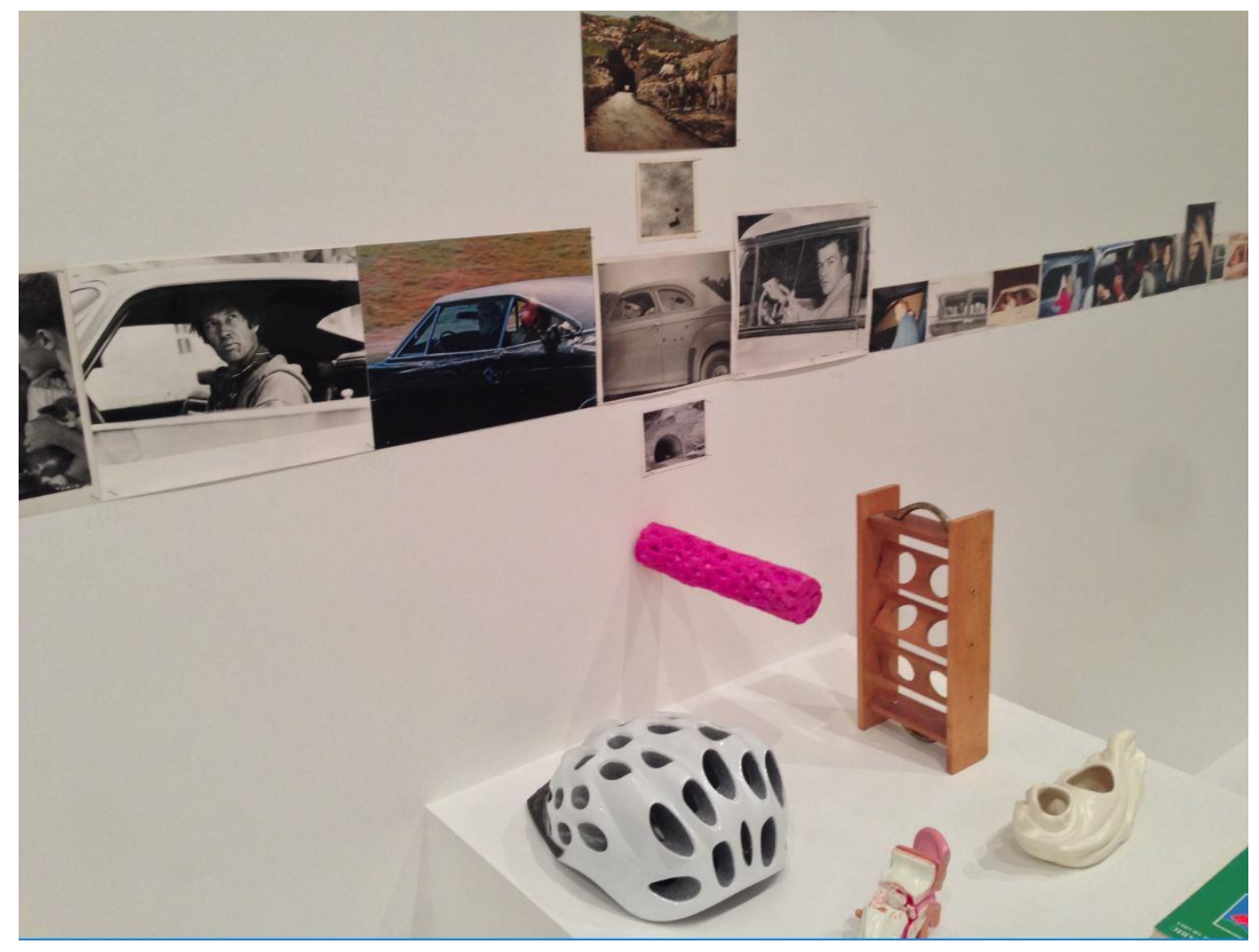

Fig. 64: Detail from Drive by (en passant) intersecting with The Museum of holes in Patrick Pound: The Great Exhibition, May 2017, photograph by author. 


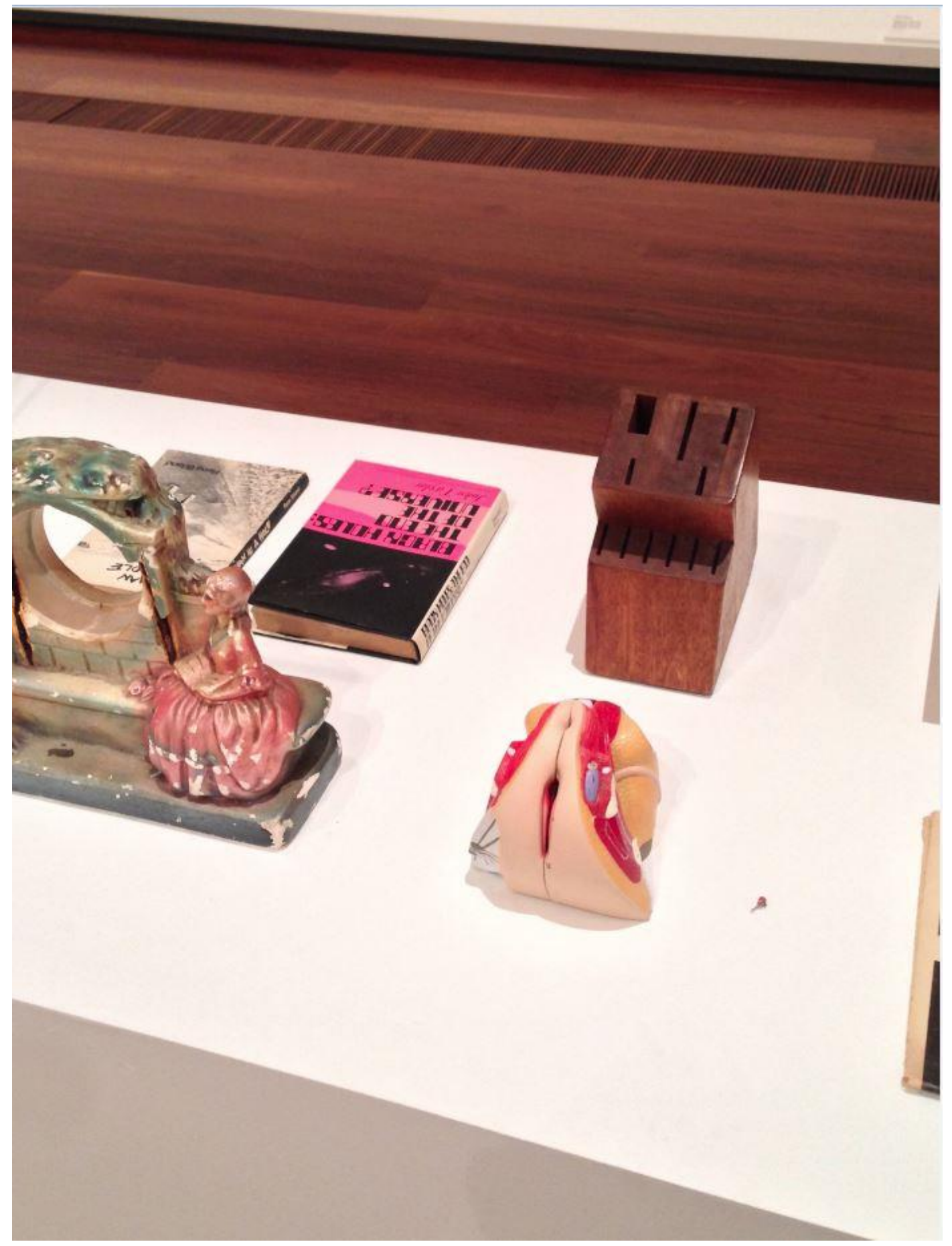

Fig. 65: Detail from The Museum of holes in Patrick Pound: The Great Exhibition, May 2017, photograph by author. 


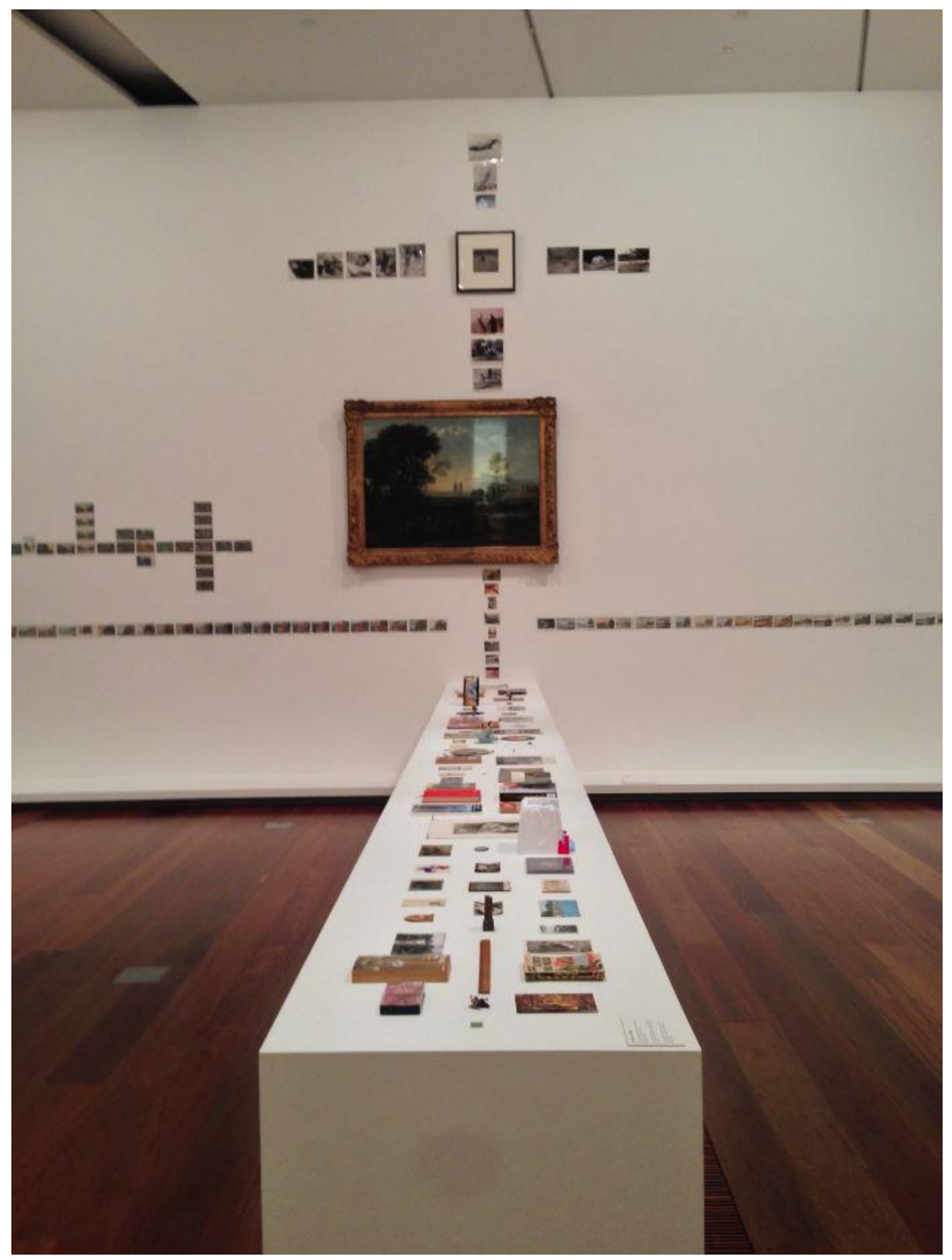

Fig. 66: Installation shot showing intersections with The Museum of falling in Patrick Pound: The Great Exhibition, May 2017, photograph by author. 


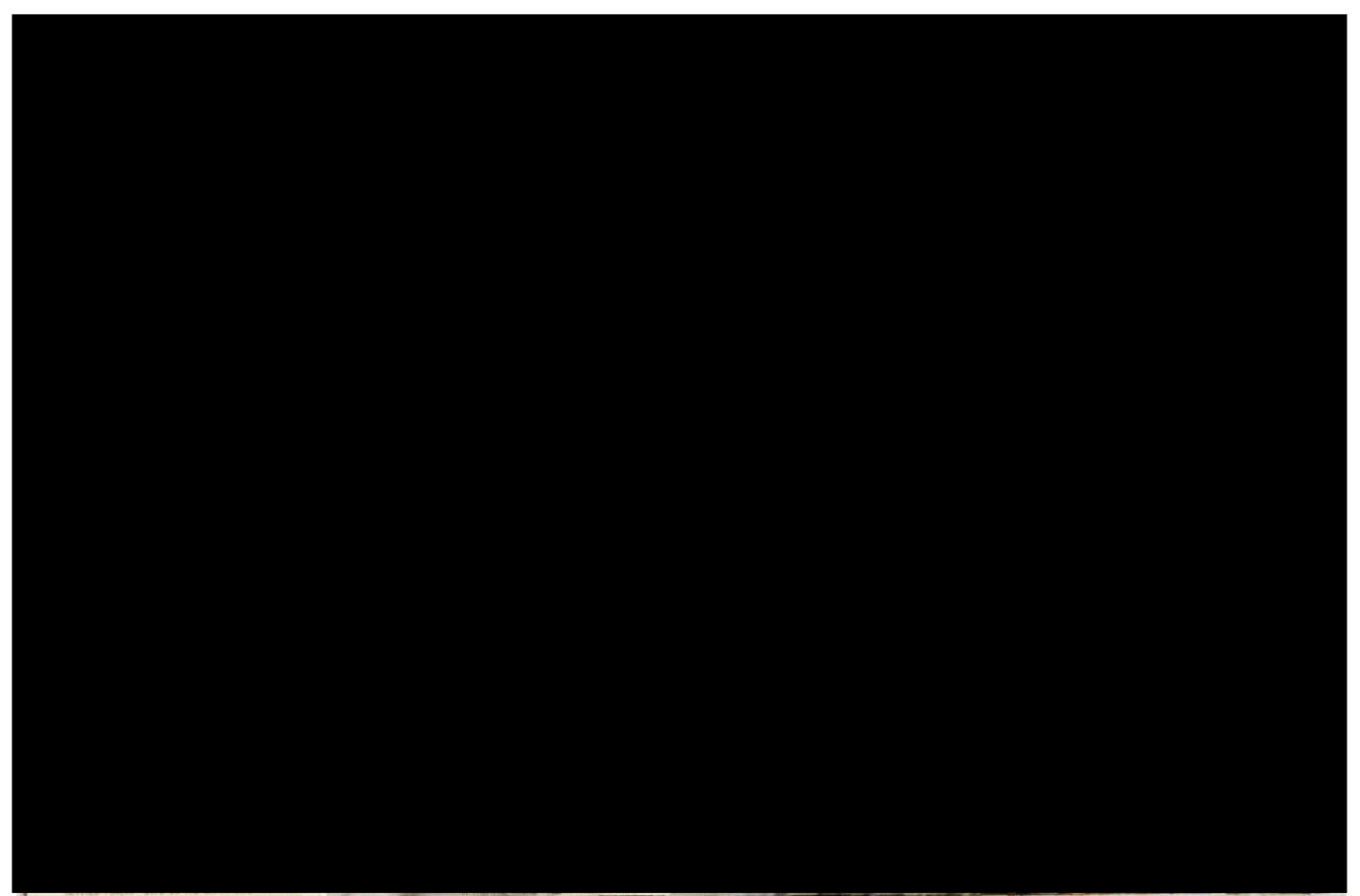

Fig. 67: Robert Rauschenberg, Stoned Moon Drawing, 1969, collage and crayon on illustration board, (Robert Rauschenberg Foundation). 


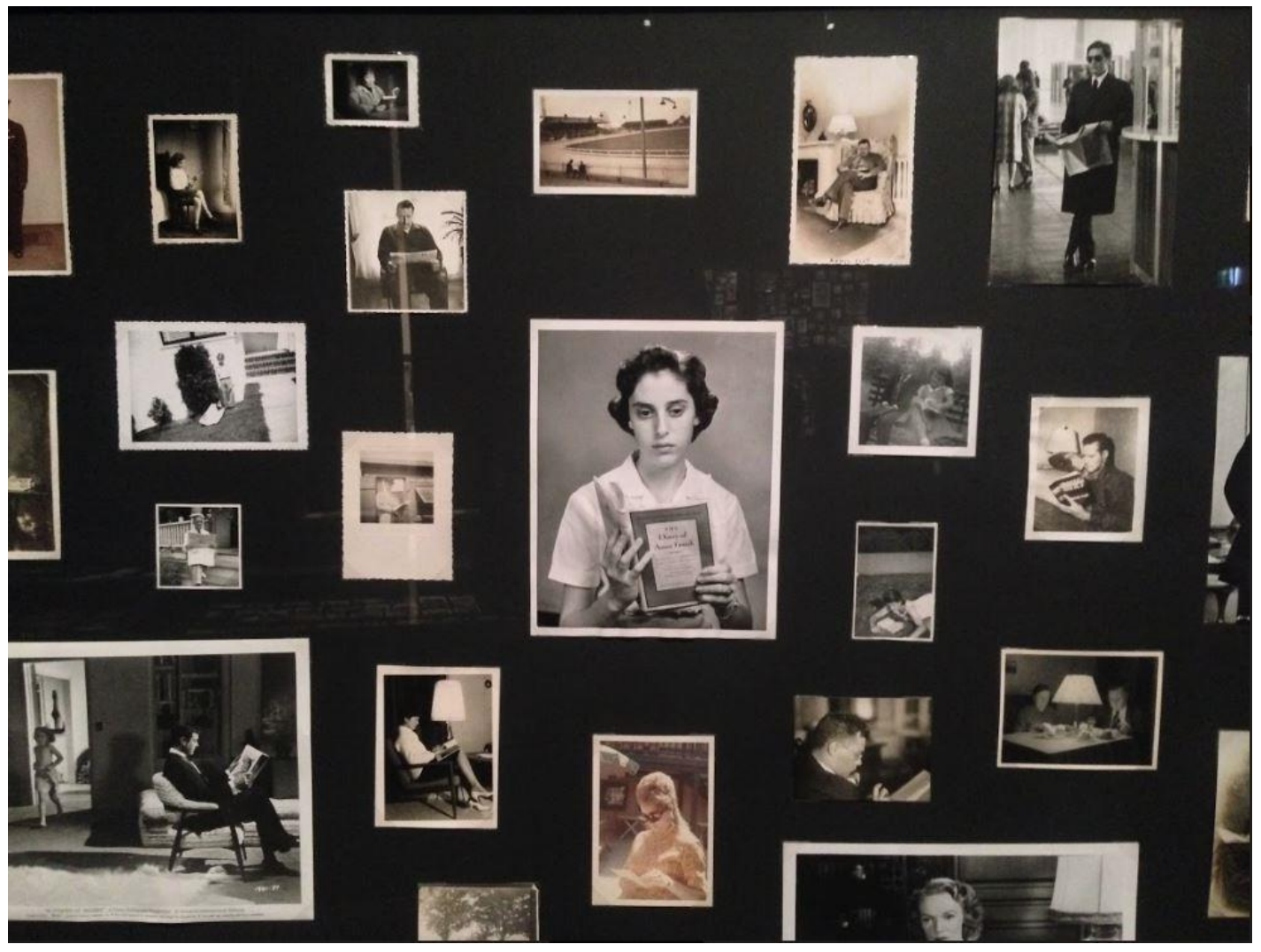

Fig. 68: Detail from The readers in Patrick Pound: The Great Exhibition, May 2017, photograph by author. 


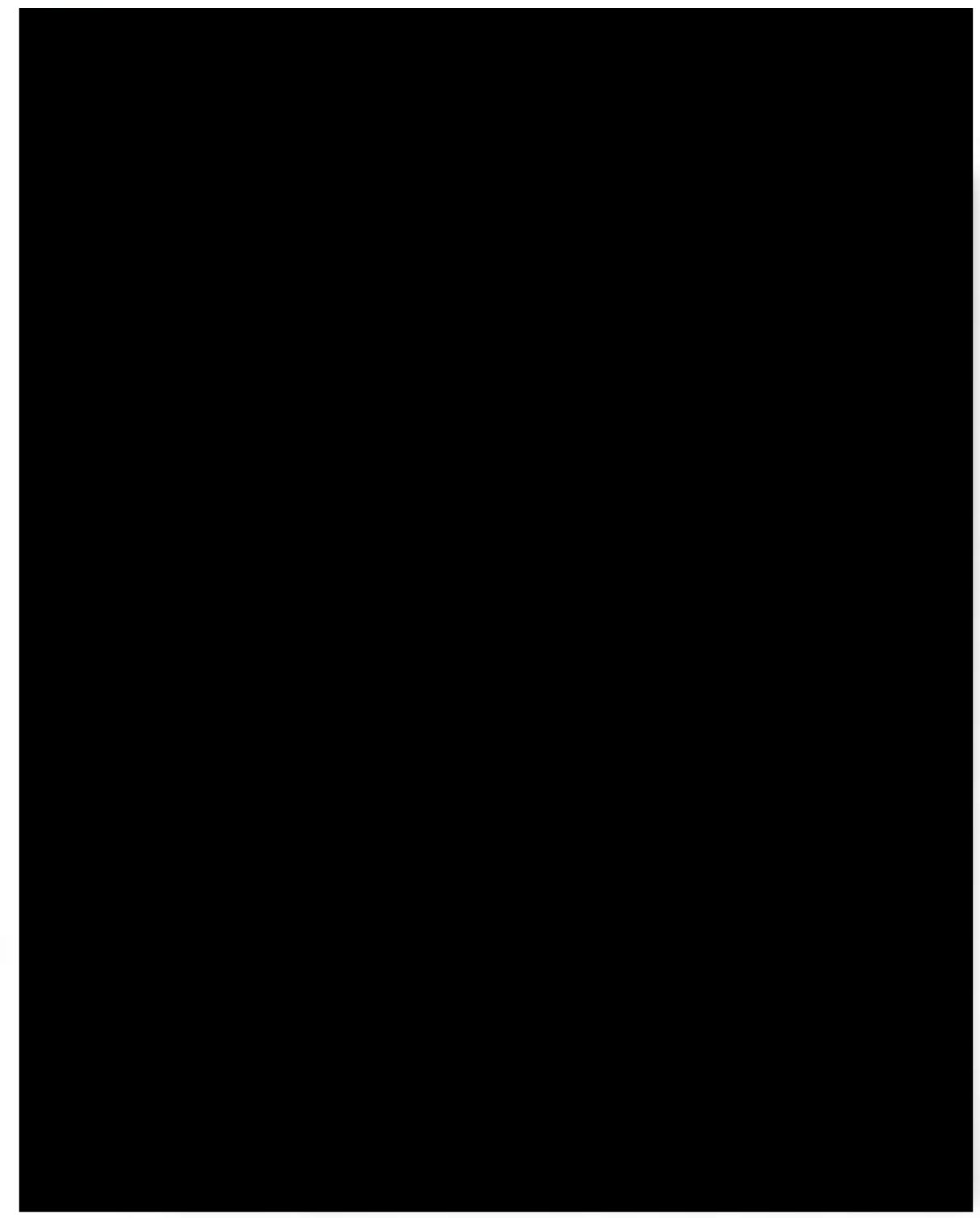

Fig. 69: Erik Kessels, IN ALMOST EVERY PICTURE \#4, 2005, book. Detail retrieved from http://kesselskramerpublishing.com/catalogue/inalmost-every-picture-4/. Accessed 30 July 2018. 


\section{Bibliography}

Annear, Judy, Geoffrey Batchen, Michael Aird, Daniel Palmer, Jane Lydon, Kate Davidson, and Martyn Jolly. The Photograph and Australia / with Essays by Geoffrey Batchen, Daniel Palmer, Michael Aird, Jane Lydon, Katherine Davidson and Martyn Jolly. Sydney, Australia: Art Gallery of New South Wales, 2015.

Art Gallery of New South Wales. "Migrants Arriving in Sydney," 2007.

https://www.artgallery.nsw.gov.au/collection/works/429.1997/.

_. "Value Added' Landscape No. 11.” Accessed February 24, 2018.

https://www.artgallery.nsw.gov.au/collection/works/75.2003/.

Australian Bureau of Statistics. "Census Reveals a Fast Changing, Culturally

Diverse Nation.” ABS, June 27, 2017.

http://www.abs.gov.au/ausstats/abs@.nsf/lookup/Media\%20Release3.

Barthes, Roland. Camera Lucida: Reflections on Photography. Translated by

Richard Howard. New York, NY: Hill and Wang, 1981.

_. "The Death of the Author." In Image, Music, Text. Translated by Stephen

Heath, 142-48. New York, NY: Noonday Press, 1988.

Barton, Christina. "Framing the Real: Postmodern Discourses in Recent New

Zealand Art." In Headlands: Thinking Through New Zealand Art, edited by

Mary Barr, 173-84. Museum of Contemporary Art, Sydney, 1992.

Batchen, Geoffrey. Burning with Desire: The Conception of Photography.

Cambridge, MA: MIT Press, 1997.

- "Camera Lucida: Another Little History of Photography." In Photography

Degree Zero: Reflections on Roland Barthes's Camera Lucida, edited by

Geoffrey Batchen, 259-74. Cambridge, MA: MIT Press, 2009.

—. Each Wild Idea: Writing, Photography, History. Boston, MA: MIT Press, 2000.

Contemporary Photography, 9-23. New York, NY: The New Press, 1999. 
—. Forget Me Not: Photography \& Remembrance. New York, NY: Princeton Architectural Press, 2004.

- "Introduction: Pictography: The Art History of Ian Burn.” In Dialogue:

Writings in Art History, by Ian Burn, xi-xix. Sydney, NSW: Allen \& Unwin

Pty Ltd, 1991.

—. "Keepers: Patrick Pound and the Art of Collecting." In The Great

Exhibition, edited by Mark Gomes, 33-45. Melbourne, VIC: National Gallery of Victoria, 2017.

-. "Life and Death.” In Suspending Time: Life-Photography-Death, edited by Yoko Mori, 108-51. Nagaizumi-Cho, Shizuoka: Izu Photo Museum Nohara, 2010.

—. "Palinode: An Introduction to Photography Degree Zero." In Photography

Degree Zero: Reflections on Roland Barthes's Camera Lucida, edited by

Geoffrey Batchen, 3-30. Cambridge, MA: MIT Press, 2009.

. "Photography and Authorship - Still Searching - Fotomuseum Winterthur,"

July 10, 2012. http://www.fotomuseum.ch/en/explore/still-

searching/articles/26932_photography_and_authorship. Accessed 13

November 2017.

— ed. Photography Degree Zero: Reflections on Roland Barthes's Camera

Lucida. Cambridge, MA: MIT Press, 2009.

—. "Snapshots: Art History and the Ethnographic Turn." Photographies 1, no.

2 (2008): 121-42.

- Suspending Time: Life-Photography-Death. Edited by Yoko Mori.

Nagaizumi-Cho, Shizuoka: Izu Photo Museum Nohara, 2010.

- ed. "Vernacular Photographies: Responses to a Questionnaire." History of Photography 24, no. 3 (2000): 229-31.

—. "Vernacular Photography." History of Photography 24, no. 3 (2000): 262-

71.

"Vernacular Photography." Grove Art Online - Oxford Art Online, January

$22,2014$. 
http://www.oxfordartonline.com/subscriber/article/grove/art/T2254188. Accessed 12 October 2017.

Bourdieu, Pierre, Luc Boltanski, Robert Castel, Jean-Claude Chamboredon, and Dominique Schnapper. Photography: A Middle-Brow Art. Translated by Shaun Whiteside. Cambridge, UK: Polity Press, 1990.

British Broadcasting Corporation. "The Great Exhibition of 1851, In Our Time BBC Radio 4.” BBC - The Great Exhibition, April 27, 2006. http://www.bbc.co.uk/programmes/p003c19x. Accessed 12 June 2018.

Buchloh, Benjamin H. D. “Conceptual Art 1962-1969: From Aesthetic of Administration to the Critique of Institutions." October 55, no. Winter (1990): $105-43$.

Burn, Ian. "Is Art History Any Use to Artists?” In Dialogue: Writings in Art History, 1-14. Sydney, NSW: Allen \& Unwin, 1991.

__. "Sidney Nolan: Landscape and Modern Life." In Radical Revisionism: An Anthology of Writings on Australian Art, edited by Rex Butler, 213-24.

Brisbane, QLD: Institute of Modern Art Publishing, 2005.

Cabanne, Pierre. Dialogues with Marcel Duchamp. Translated by Ron Padgett. London, UK: Thames \& Hudson, 1971.

Carrier, David, and David Jones. The Contemporary Art Gallery: Display, Power and Privilege. Cambridge, UK: Cambridge Scholars Publishing, 2016.

Cole, Georgina. “The Compound Lens Project.” Art Gallery NSW, April 13, 2015. https://www.artgallery.nsw.gov.au/blog/posts/compound-lens-project/. Accessed 12 May 2018.

Cox, Will. "Scouring EBay for Art with Patrick Pound." Broadsheet, April 24, 2017. https://www.broadsheet.com.au/melbourne/art-anddesign/article/scouring-ebay-art-patrick-pound-ngv. Accessed 15 July 2018.

Culler, Jonathan. Barthes. Edited by Frank Kermode. Glasgow, Scotland: Fontana Paperbacks, 1983.

Curnow, Ben. PATRICK POUND: URI INTERNATIONAL. (Wellington, NZ: Hamish McKay, 1993). 
Derrida, Jacques. “Archive Fever: A Freudian Impression.” Edited by Eric Prenowitz. Diacritics 25, no. 2 (1995): 9-63. https://doi.org/10.2307/465144. Accessed 12 October 2017.

Druckrey, Timothy. "Instability and Dispersion." In Over Exposed: Essays on Contemporary Photography. New York, NY: The New Press, 1999.

Dunne, Carey. “Art Historians Find Racist Joke Hidden Under Malevich's 'Black Square."” Hyperallergic, November 13, 2015.

https://hyperallergic.com/253361/art-historian-finds-racist-joke-hidden-undermalevichs-black-square/. Accessed 25 May 2018.

eBay Incorporated. “Our History - EBay Inc.” Our History, N.d.

https://www.ebayinc.com/our-company/our-history/. Accessed 20 July 2018. eBay News Team. "An Easier Way to Search EBay: Computer Vision with Find It On EBay and Image Search Is Now Live.” Our News, October 15, 2017. https://www.ebayinc.com/stories/news/an-easier-way-to-search-ebaycomputer-vision-with-find-it-on-ebay-and-image-search-is-now-live/. Accessed 20 July 2018.

Edgar, Ray. "From EBay to the NGV: Patrick Pound's 'mad Folly' Makes Art of Our Cast-Offs." The Sydney Morning Herald, March 31, 2017. http://www.smh.com.au/entertainment/art-and-design/from-ebay-to-the-ngvpatrick-pounds-mad-folly-makes-art-of-our-castoffs-20170315-guz8qu.html. Accessed 12 October 2017.

Enwezor, Okwui, and International Center of Photography, eds. Archive Fever: Uses of the Document in Contemporary Art / Okwui Enwezor. Göttingen; London; Steidl: Thames \& Hudson, 2008.

Eveleth, Rose. "How Many Photographs of You Are Out There In the World?" The Atlantic, February 11, 2015.

https://www.theatlantic.com/technology/archive/2015/11/how-manyphotographs-of-you-are-out-there-in-the-world/413389/. Accessed 27 May 2018.

Filipovic, Elena. The Apparently Marginal Activities of Marcel Duchamp. Cambridge, MA; London, UK: The MIT Press, 2016. 
Finch, Maggie. "A Conversation: Patrick Pound and Maggie Finch.” In The Great Exhibition, edited by Mark Gomes, 9-32. Melbourne, VIC: National Gallery of Victoria, 2017.

—. "Introduction." In The Great Exhibition, edited by Mark Gomes, 1-8.

Melbourne, VIC: National Gallery of Victoria, 2017.

—. "Patrick Pound: The Great Exhibition Artwork Labels." National Gallery of Victoria, 2017. https://www.ngv.vic.gov.au/wpcontent/uploads/2016/09/PatrickPound_ArtworkLabels.pdf. Accessed 23 May 2017.

—. The Great Exhibition. Edited by Mark Gomes. Melbourne, VIC: National Gallery of Victoria, 2017.

Foster, Hal. “An Archival Impulse.” October 110, no. Autumn (2004): 3-22. Ginsberg, Elisabeth. "Mining the Museum." In Beautiful Trouble: A Toolbox for Revolution, edited by Boyd Andrew and Mitchell D. Oswald, 334-37. New York, NY: London, UK: OR Books, 2012.

Girst, Thomas. The Duchamp Dictionary. London, UK: Thames \& Hudson, 2014.

Goldblatt, David B., Stephanie Patridge, and Lee B. Brown, eds. Aesthetics: A Reader in Philosophy of the Arts. 4th ed. New York, NY: London, UK: Taylor and Francis, 2018.

“Google Images.” Accessed July 30, 2018. https://images.google.com/?gws_rd=ssl. Greene, Roland, Stephen Cushman, Clare Cavanagh, Jahan Ramazani, Paul Rouzer, Harris Feinsod, David Marno, and Alexandra Slessarev, eds. "Oulipo.” The Princeton Encyclopedia of Poetry and Poetics: Fourth Edition. Princeton, NJ: Princeton University Press, 2012. http://www.jstor.org/stable/j.ctt2tt8jz.23. Accessed 17 September 2017.

Grishin, Sasha. The Art of John Brack. Vol. 1. 2 vols. Melbourne, VIC: Oxford University Press, 1990.

Grönberg, Cecilia. "Photography, History, Curating - a Conversation with Geoffrey Batchen. CUNY Grad Center, New York, May 5 2010.” OEI 53-54 (2011): 511-19.

Halle, Howard, and Fred Wilson. "Mining the Museum." Grand Street, 1993. 
Hanfling, Edward. "Exhibitions: Thomas Newman Pound.” Art New Zealand, 2017. Harnoncourt, Anne d', and Kynaston McShine, eds. Marcel Duchamp. Munich, Germany: Prestel-Verlag, 1989.

Harrison, Thomas. "The Essayistic Novel and Mode of Life: Robert Musil's The Man without Qualities.” Republics of Letters 4, no. 1 (October 2014): 1-14. Heyman, Stephen. "Photos, Photos Everywhere." The New York Times, January 19, 2018, sec. Arts.

https://www.nytimes.com/2015/07/23/arts/international/photos-photoseverywhere.html. Accessed 27 May 2018.

Hill, Peter. “An Encyclopaedia of Patrick Pound's Superfictions.” Photofile 91 (December 2010): 58-67.

_. "Extracts from: The Encyclopaedia of Photofictions." Photofile 59 (April 2000): 14-24.

Kessels, Erik. "24 Hrs in Photos.” Kesselskramer, N.D. http://www.kesselskramer.com/exhibitions/24-hrs-of-photos. Accessed 16 February 2018.

KESSELSKRAMER. "IN ALMOST EVERY PICTURE 1.”

kesselskramerpublishing, N.D.

http://www.kesselskramerpublishing.com/catalogue/inalmosteverypicture1/. Accessed 16 February 2018. “IN ALMOST EVERY PICTURE 4.” kesselskramerpublishing, N.D. http://kesselskramerpublishing.com/catalogue/in-almost-every-picture-4/. Accessed 16 February 2018. -. "IN ALMOST EVERY PICTURE 13." kesselskramerpublishing, N.D. http://kesselskramerpublishing.com/catalogue/in-almost-every-picture-13/. Accessed 16 February 2018.

_. "USEFUL PHOTOGRAPHY 1.” kesselskramerpublishing, N.D. http://www.kesselskramerpublishing.com/catalogue/useful-photography-1/. Accessed 16 February 2018.

Kramer, Hilton. "Exhibiting The Family of Man.” In Public Photographic Spaces: Exhibitions of Propaganda, from Pressa to The Family of Man, 1928-55, 
edited by Jorge Ribalta, 437-46. Barcelona, Spain: Museu d'Art Contemporani de Barcelona, 2009.

Krauss, Rosalind. "In the Name of Picasso." In The Originality of the Avant-Garde and Other Modernist Myths, 23-41. Cambridge, MA: MIT Press, 1985.

—. "Notes on the Index: Part 1." In The Originality of the Avant-Garde and Other Modernist Myths, 198-209. Cambridge, MA: MIT Press, 1985.

—. "Perpetual Inventory." October 88, no. Spring (1999): 86-116.

_. "Photography's Discursive Spaces." In The Originality of the Avant-Garde and Other Modernist Myths, 131-50. Cambridge, MA: MIT Press, 1985.

Leonard, Robert. “Enchanted Hunter.” robertleonard.com, May 21, 2017. http://robertleonard.org/2017/05/enchanted-hunter/. Accessed 15 June 2018.

Leonard, Robert, and Kelly Carmichael, eds. Patterns of Intention. (Auckland, NZ: Artspace, 1998).

Maizel, Neil. "Patrick Pound: The Great Exhibition.” Arena Magazine, July 2017.

McAuliffe, Chris. “John Brack: The Forgotten People.” In Radical Revisionism: An Anthology of Writings on Australian Art, edited by Rex Butler, 233-39.

Brisbane, QLD: Institute of Modern Art Publishing, 2005.

McCaughey, Patrick. "The Complexity of John Brack.” In John Brack: A Retrospective Exhibition, by Robert Lindsay, 7-10. Melbourne, VIC: National Gallery of Victoria, 1987.

McNaught, Rowan, and Patrick Pound. Thoughts of Sorts. 2017. Computer Programme. www.thoughts-of-sorts.com. Accessed 2 May 2018.

Medsafe. "Product Information." Medsafe, 2015. http://www.medsafe.govt.nz/profs/Datasheet/p/PrepkitCsol.pdf. Accessed 30 July 2018.

Miller, Nick. "London Awaits Australia, the Exhibition.” The Age, May 3, 2013. http://www.theage.com.au/entertainment/london-awaits-australia-theexhibition-20130503-2iwzp.html. Accessed 13 September 2017.

Ministère de 1'Economie. "The Family of Man.” The Family of Man, N.d. https://www.visitluxembourg.com/en/place/museum/the-family-of-man. Accessed 30 July 2018. 
Mitchell, W. J. T. What Do Pictures Want? Chicago, IL; London, UK: The University of Chicago Press, 2005.

National Collection of Fine Arts. Robert Rauschenberg. Washington, DC: National Collection of Fine Arts, Smithsonian Institution, 1976.

National Gallery of Victoria. "Bennelong." Collection Online, N.d. http://www.ngv.vic.gov.au/explore/collection/work/89916/. Accessed 30 July 2018.

_. "Migrants Arriving in Sydney," n.d. https://nga.gov.au/federation/Detail.cfm?WorkID=77779. Accessed 30 July 2018

—. "Visit." NGV, N.D. https://www.ngv.vic.gov.au/visit/. Accessed 30 July 2018

NGV Melbourne. VAN GOGH AND THE SEASONS - The Exhibition Film. YouTube. Accessed July 30, 2018. https://www.youtube.com/watch?v=Qa3f5FMf8zw\&feature=youtu.be. Accessed 27 June 2018.

O'Doherty, Brian. Inside the White Cube: The Ideology of the Gallery Space. Berkeley, Los Angeles: California: University of California Press, 1999. O'Neill, Paul. The Culture of Curating and the Curating of Culture(s). Cambridge, MA: The MIT Press, 2012.

Palmer, Daniel. "A Collaborative Turn in Contemporary Photography?" Photographies 6 (2013): 117-25.

- Photography and Collaboration: From Conceptual Art to Crowdsourcing. London, UK; New York, NY: Bloomsbury Academic, 2017.

_. "The Long Sleep of Photography." In The Big Sleep, edited by Patrick Pound. Melbourne, VIC: Patrick Pound, 2015.

—. "The Mistake in Photography: Patrick Pound, Jackson Eaton and the Paradoxical Self Image.” Dissect 2 (2015): 15-32.

Perec, Georges. "Introduction.” In Thoughts of Sorts, translated by David Bellos. Boston, MA: David R. Godine Publisher, 2009. 
_. Life: A User's Manual. Translated by David Bellos. Vintage Classics. London, UK: Random House, 2008.

—. Thoughts of Sorts. Translated by David Bellos. Boston, MA: David R.

Godine Publisher, 2009.

—. "Thoughts of Sorts / Sorts of Thoughts." In Thoughts of Sorts, translated by David Bellos. Boston, MA: David R. Godine Publisher, 2009.

Picard, Liza. "The Great Exhibition.” The British Library, 2009.

https://www.bl.uk/victorian-britain/articles/the-great-exhibition. Accessed 30 July 2018.

Pollock, Griselda. "Artists Mythologies and Media Genius, Madness and Art History." Screen 21, no. 3 (Fall) (1980): 57-96.

Pound, Patrick. "C.V.-A Work in Progress." Cabinet Magazine, December 20, 2017. http://www.cabinetmagazine.org/issues/18/pound.php. Accessed 20 July 2018.

—. Documentary Intersect. (Wellington, NZ: Adam Art Gallery, 2016).

_. Fragments and Fakes. (Wellington, NZ: Southern Cross Gallery, 1993).

- International. (Palmerston North, NZ: Manawatu Art Gallery, 1994).

—. Little Deceits - Art Crimes. (Melbourne, VIC: Michael Wardell Gallery, 1992).

—. "Patrick Pound: Curriculum Vitae," Self-published material, 1996. Patrick Pound: Extracts from a Library. (Auckland, NZ: Sue Crockford Gallery, 1994).

- "Significant Documents: Photography and Narrative from Alvin Langdon Coburn's and Henry James's New York Edition (1907-9), to Walker Evans's and James Agee's ‘Let Us Now Praise Famous Men' (1941, 1960),’ 2011. http://minerva-access.unimelb.edu.au/handle/11343/36628. Accessed 16 July 2017.

- Systematic: Towards a Theory of Everything. (Australia: Australia Council, 1999).

—. "The Gallery of Air." National Gallery of Victoria, 2014. https://www.ngv.vic.gov.au/essay/the-gallery-of-air/. Accessed 14 July 2018. 
—. The Space Museum Guide / Collected Works: Telling Things. (Melbourne, VIC: Fehily Contemporary, 2011).

—. The Tailor's Library. (Melbourne, VIC, Michael Wardell Gallery, 1996).

Pound, Patrick, and Rowan McNaught. Compound Lens. 2015 2014. Web Application. http://compound-lens.com/. Accessed 12 May 2018.

Pound, Patrick, and Dr. Leon Noel. Patrick Pound: Rear Vision (Sydney, NSW: Grant Pirrie, 2005).

Pound, Patrick, and Anthony Tromp. Patrick Pound: Soft. (Sydney, NSW: Grant Pirrie, 2004).

Preziosi, Donald. The Art of Art History: A Critical Anthology. 2nd ed. Oxford History of Art. Oxford, UK: Oxford University Press, 2009.

Ribalta, Jorge, ed. Public Photographic Spaces: Exhibitions of Propaganda, from Pressa to The Family of Man, 1928-55. Barcelona, Spain: Museu d'Art Contemporani de Barcelona, 2009.

Ribière, Mireille. "Georges Perec's Enduring Presence in the Visual Arts.” In The Afterlives of Georges Perec, edited by Rowan Wilken and Justin Clemens, 2344. Edinburgh, UK: Edinburgh University Press, 2017.

Roberts, Sarah. "Erased de Kooning Drawing.” SFMOMA, 2013. https://www.sfmoma.org/artwork/98.298/essay/erased-de-kooning-drawing/. Accessed 30 July 2018.

Roussel, Raymond. How I Wrote Certain Of My Books. Edited by Trevor Winkfield. Boston, MA: Exact Change, 1995.

Rule, Dan. "Lost \& Found.” Art Collector, 2013.

Sachsse, Rolf. “Joachim Schmid's Archiv.” Edited by Geoffrey Batchen. History of Photography 24, no. 3 (2000): 255-61.

Sandeen, Eric. "The Show You See With Your Heart. The Family of Man on Tour in the Cold War World." In Public Photographic Spaces: Exhibitions of Propaganda, from Pressa to The Family of Man, 1928-55, edited by Jorge Ribalta, 471-87. Barcelona, Spain: Museu d'Art Contemporani de Barcelona, 2009. 
Schmid, Joachim. “Archiv (1986-1999) - Joachim Schmid.” N.D.

http://www.lumpenfotografie.de/2006/01/01/archiv-1986-1999/. Accessed July 3,2018 .

—_. "Reload Currywurst." Edited by Joan Fontcuberta, 286-99. Madrid, Spain: Ministerio de Cultura, 2008.

Sheehan, Tanya. "Ordinary Masters: Mike Disfarmer and the Reclamation of Vernacular Photography and Afterword." In Becoming Disfarmer, edited by Chelsea Spengemann, Gil Blank, and Tanya Sheehan, 103-14, 163. New York, NY: Neuberger Museum of Art, 2014.

Siegel, Jeanne, ed. “After Sherrie Levine.” In Art Talk: The Early 80s, 245-56.

Boston, MA: De Capo Press, 1988.

Smith, Terry, ed. Talking Contemporary Curating. New York, NY: Independent Curators International, n.d.

_. "The Provincialism Problem." Journal of Art Historiography, no. 4 (June 2011): 1-14.

Solomon-Godeau, Abigail. Photography at the Dock: Essays on Photographic History, Institutions, and Practices. 5th ed. Minneapolis, MN: University of Minnesota Press, 2009.

Sontag, Susan. On Photography. London, UK: Penguin Classics, 2002.

Spoonley, Paul. "Being Here and Being Pakeha." In Pakeha: The Quest for Identity in New Zealand, edited by Michael King, 146-56. Auckland, NZ: Penguin Books, 1991.

Squiers, Carol. “Introduction.” In Over Exposed: Essays on Contemporary Photography, 1-8. New York, NY: The New Press, 1999.

$\longrightarrow$, ed. Over Exposed: Essays on Contemporary Photography. New York, NY: The New Press, 1999.

Steichen, Edward. "Introduction.” In Public Photographic Spaces: Exhibitions of Propaganda, from Pressa to The Family of Man, 1928-55, edited by Jorge Ribalta, 433. Barcelona, Spain: Museu d'Art Contemporani de Barcelona, 2009. 
Talbot, William Henry Fox. Some Account Of The Art Of Photogenic Drawing, Or The Process By Which Natural Objects May Be Made To Delineate Themselves Without The Aid Of The Artist's Pencil. London, UK: R. \& J. E. Taylor, Red Lion Court, 1839.

Taylor, Rob. "Frazer, Painting Minimalism and Quoting Romanticism.” Dominion Post. December 20, 1989.

—_. "Witty Parodies and Sophisticated Cutouts." Dominion Post. November 17, 1987.

The Museum of Modern Art. "The Family of Man | MoMA.” The Family of Man. Accessed July 30, 2018. https://www.moma.org/calendar/exhibitions/2429. Accessed 30 July 2018.

—_ "The Family of Man Master Checklist.” Master Checklist, 1955. https://www.moma.org/documents/moma_master-checklist_325962.pdf. Accessed 30 July 2018.

The Story Behind Erik Kessels' Obsession, How He Breathes New Life Into Amateur Photography. YouTube, 2017.

https://www.youtube.com/watch?v=7_Yjf511G9k. Accessed 4 July 2018.

Turnbull, Paul. Science, Museums and Collecting the Indigenous Dead in Colonial Australia. Palgrave Studies in Pacific History. Cham, Switzerland: Springer International Publishing, 2017.

Turner, Fred. "The Family of Man and the Politics of Attention in Cold War America." Public Culture 24, no. 1 (2012): 55-84.

United Nations Educational, Scientific and Cultural Organization. "The Family of Man.” Memory of the World, 2003.

http://www.unesco.org/new/en/communication-and-information/memory-ofthe-world/register/full-list-of-registered-heritage/registered-heritage-page3/family-of-man/. Accessed 30 July 2018.

Vasari, Giorgio. "Life of Leonardo Da Vinci, Florentine Painter and Sculptor, 14521519.” In Lives of the Artists, I:255-71. London, UK: Penguin Books, 1987. Wedde, Ian. "Prints That Buckle.” Evening Post. November 11, 1987. 
Welles, Orson, François Reichenbach, Gary Graver, and Oja Kodar (dirs.). F for Fake (Germany, Planfilm, 1973), Blu-Ray.

Western Australia Government. "Scamnet.” WA Scamnet, n.d.

http://www.scamnet.wa.gov.au/scamnet/Scam_types-Buying_or_selling-

False_billing-International_Biographical_Centre.htm. Accessed 12 October 2017.

Wilken, Rowan, and Justin Clemens, eds. The Afterlives of Georges Perec.

Edinburgh, UK: Edinburgh University Press, 2017.

Wolff, Mark. "Invoking the Oracle: Perec, Algorithms and Conceptual Writing." In The Afterlives of Georges Perec, edited by Rowan Wilken and Justin Clemens, 85-102. Edinburgh, UK: Edinburgh University Press, 2017. 